\title{
O CONSELHO NACIONAL DO TRABALHO E A CONSTRUÇÃO DOS DIREITOS SOCIAIS NO BRASIL
}

Dissertação de Mestrado

Professor Orientador: Samuel Rodrigues Barbosa

UNIVERSIDADE DE SÃO PAULO

FACULDADE DE DIREITO

São Paulo

2013 


\section{O CONSELHO NACIONAL DO TRABALHO E A CONSTRUÇÃO DOS DIREITOS SOCIAIS NO BRASIL}

Dissertação apresentada à

Faculdade de Direito da Universidade de São Paulo para obtenção de título de Mestre em Direito.

Área de Concentração: Filosofia e Teoria Geral do Direito

Prof. Orientador: Samuel

Rodrigues Barbosa 


\section{FOLHA DE APROVAÇÃO}

NOME: Marcos Untura Neto

TÍTULO: O Conselho Nacional do Trabalho e a Construção dos Direitos Sociais no Brasil

Dissertação apresentada à Faculdade de Direito da Universidade de São Paulo para obtenção de título de Mestre em Direito.

Aprovado em:

\section{BANCA EXAMINADORA}

Prof. Dr. Samuel Rodrigues Barbosa

Julgamento:

Prof. Dr.

Julgamento:

Prof. Dr.

Julgamento:
Instituição: Faculdade de Direito da Universidade de São Paulo

Assinatura:

Instituição:

Assinatura:

Instituição:

Assinatura: 


\section{AGRADECIMENTOS}

Os três anos, o tempo gasto nesse trabalho, são suficientes para promover muitas mudanças de vida. Mas a passagem do tempo também serve para decidir rumos e consolidar convicções. Por isso inicio agradecendo ao Professor Samuel Rodrigues Barbosa, orientador e amigo, que acreditou em minha capacidade como pesquisador e pacientemente me ajudou a definir os rumos do presente trabalho, colaborando decisivamente para que minhas inquietações sobre a história das instituições do mundo do trabalho pudessem se transformar em firme convicção de que era possível abandonar linhas e métodos de pesquisa arraigados em minha trajetória acadêmica, para prosseguir na pesquisa de fontes ainda inéditas no âmbito da história do direito do trabalho no Brasil.

Agradeço também aos Professores José Eduardo Campos de Oliveira Faria e José Rodrigo Rodriguez pelas observações pertinentes e atentas trazidas no exame de qualificação. O Professor Faria trouxe inúmeras informações sobre atores relevantes da época, sobre suas filiações político-ideológicas, sobre fontes de pesquisa e bibliografia de interpretações sobre o período. E eu não poderia deixar de agradecer de forma especial e destacada o Professor Faria por ter me dado a oportunidade de participar do Programa Especial de Treinamento (PET-CAPES) durante os anos de minha graduação na São Francisco e por ter me apresentado ao excepcional grupo de pesquisadores e professores por ele formado. Foi no PET que se abriram para mim todos os caminhos da pesquisa multidisciplinar em direito. E olhando para trás hoje tenho a certeza de que este trabalho é decorrência direta das reflexões, reuniões, cursos e trabalhos de assistência em pesquisa no grande tema das transformações do Estado brasileiro de que participei por meio do PET.

O Professor José Rodrigo também apontou caminhos de fundamental importância para o desenvolvimento do trabalho, em especial a relação entre inovações dogmáticas e contexto social. Agradeço-o também por ter me apresentado ao Centro de Pesquisa em História Social da Cultura do Instituto de Filosofia e Ciências Humanas da UNICAMP, onde pude ter contato com uma magnífica produção historiográfica sobre o mundo do trabalho no Brasil.

Eu jamais poderia esquecer de minha família: Denise Conselheiro, cujo amor paciente e compreensivo me ajudou a superar momentos de descrédito e dificuldades. A meus pais, Liliana e Marcos, agradeço o apoio e a compreensão em relação a minhas seguidas ausências do convívio familiar no último ano. 
A dissertação não teria chegado a bom termo sem o inestimável e desprendido auxílio na condução de meus afazeres na advocacia trabalhista prestado por Horácio Conde Ferreira, fraterno amigo e advogado trabalhista brilhante. O cotidiano da lida com os processos, do relacionamento com as partes e com outros operadores do direito, além da sempre desafiadora atividade de lidar com uma Consolidação que ainda contém muito daquilo que foi concebido no período estudado, também são fontes preciosas de inquietações sobre o mundo das relações de trabalho.

Por fim, agradeço a Fabio Roberto Correa Castilho pelos diálogos instigantes e pelo compartilhamento de experiências acadêmicas.

São Paulo, Liberdade, janeiro de 2013. 


\section{RESUMO}

UNTURA NETO, Marcos. O Conselho Nacional do Trabalho e a construção dos direitos sociais no Brasil. 2013. 190 f. Dissertação (Mestrado) - Faculdade de Direito da Universidade de São Paulo, São Paulo, 2013.

As obras dedicadas à história do direito do trabalho costumam dar pouca atenção à fase anterior à Consolidação das Leis do Trabalho, em especial à chamada fase ministerial (ou administrativa) da Justiça do Trabalho. O objetivo da presente dissertação é produzir, por meio da análise de processos submetidos ao Conselho Nacional do Trabalho, um retrato do funcionamento do sistema burocrático de distribuição de justiça em matéria trabalhista e previdenciária montado na estrutura do Poder Executivo, mais especificamente no Ministério do Trabalho, Indústria e Comércio, especialmente entre 1934 e 1946, quando o Conselho Nacional do Trabalho passou a exercer função propriamente judicante. Para isso, buscou-se desvendar o desenho institucional do Conselho Nacional do Trabalho, a atuação dos conselheiros, as fontes doutrinárias a que recorriam, os personagens que gravitavam no seu entorno, todos dedicados ao manejo do sistema criado, de modo a observar como o aparato burocrático composto pelo Conselho Nacional do Trabalho (e demais órgãos a ele vinculados) construiu as primeiras soluções jurídicas para o reconhecimento e o enforcement dos direitos sociais no Brasil, em especial os de índole trabalhista e previdenciária. A colocação em movimento dos direitos sociais pelo CNT, pela doutrina e pelos demais atores relevantes mostram uma atuação efetiva dos órgãos de distribuição de justiça trabalhista, com elevada demanda pelos serviços por parte dos trabalhadores, que souberam articular um discurso fortemente impregnado da linguagem da legalidade para fazer valer suas pretensões. As construções das soluções dos casos são as mais variadas, ora com remessa ao texto legal ora buscando os institutos propagados como fundamentais no arcabouço do "novo direito", tais como equidade, espírito da lei e vontade do legislador.

Palavras-chave: 1. Conselho Nacional do Trabalho 2. Direitos sociais 3. história do direito do trabalho 4. discurso 5. consciência legal 6. equidade 


\begin{abstract}
UNTURA NETO, Marcos. The National Labor Commission and the construction of social rights in Brazil. 2013. 190 p. Dissertação (Mestrado) - Faculdade de Direito da Universidade de São Paulo, São Paulo, 2013.

Labor law history studies do not usually focus attention to the period preceding the Consolidation of Brazilian Labor Laws, in particular to the so-called ministerial (or administrative) period. This essay intends to produce, by means of the analysis of labor claims submitted to the National Labor Commission, a portrait of the bureaucratic system of labor and social security justice in operation inside the structure of the Executive Branch, specially between 1934 and 1946, when the Commission started to perform its judicative legal attribution. For this purpose, we presented the National Labor Commission's institutional design, the commissioners actions, the doctrine sources consulted, the players surrounding it, all of them dedicated to manage the created system, in order to build the first legal solutions aimed at recognizing and enforcing social rights in Brazil, specially labor and social security rights. The setting in motion of the social rights by the NLC, by the doctrine and by other relevant players shows an effective action of the bodies of labor justice administration and workers high demand for its services. We also show the workers' ability to articulate a discourse strongly pervaded by the rule of law jargon in order to enforce their rights. The solutions for the cases vary, sometimes containing a reference to the legal text and in other circumstances using legal institutions fundamentally related to the "new law", such as fairness, spitit of the law and will of the legislator.
\end{abstract}

Keywords: 1. National Labor Commission 2. Social rights 3. Labor law history 4. discourse 5. legal awareness 6. fairness 


\section{LISTA DE FOTOGRAFIAS}

Fotografia 1 - Ministro Joaquim Pedro Salgado Filho

Fotografia 2 - Ministro Waldemar Falcão. 36

Fotografia 3 - Ministro Agamenon Magalhães. 47

Fotografia 4 - Aviso publicado no Diário Oficial da União de 5 de junho de 1933 130

Fotografia 5 - Ministro Alexandre Marcondes Filho. 131

Fotografia 6 - Bilhete escrito por Segadas Viana a Evaristo de Moraes. 132 


\section{LISTA DE GRÁFICOS}

Gráfico 1 - Organização do CNT conforme disposto no Decreto n. 24.784, de 14 de julho

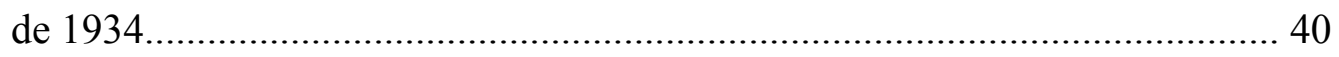

Gráfico 2 - Organização do CNT conforme disposto no Decreto n. 1.346, de 15 de junho

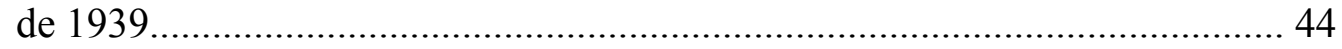




\section{SUMÁRIO}

INTRODUÇÃO.

\section{CAPÍTULO 1 \\ IDEIAS SOBRE A CONSTRUÇÃO DOS DIREITOS SOCIAIS NO BRASIL}

16

$1.1 \mathrm{O}$ mito da outorga

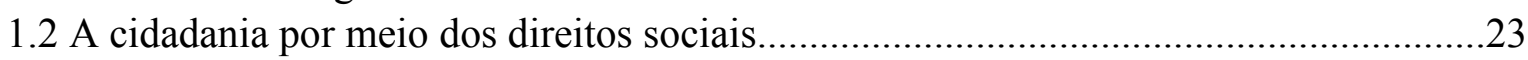

1.3 Capitalismo tardio e demanda por mão de obra.......................................................26

1.4 As ideias sobre a construção dos direitos sociais e a reprodução da memória em obras jurídicas.

\section{CAPÍTULO 2 \\ O DESENHO JURÍDICO-INSTITUCIONAL DO CONSELHO NACIONAL DO TRABALHO E SUA INSERÇÃO NA POLÍTICA VARGUISTA}

\section{CAPÍTULO 3 \\ A DISTRIBUIÇÃO DE JUSTIÇA PELO CONSELHO NACIONAL DO TRABALHO E O PROCESSO DE AFIRMAÇÃO BUROCRÁTICA DO "NOVO DIREITO"}

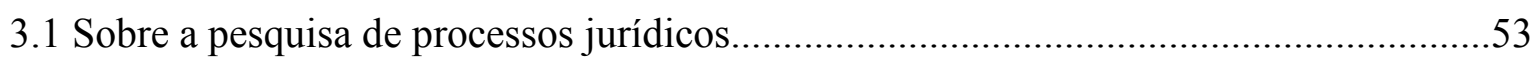

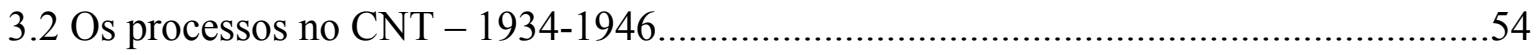

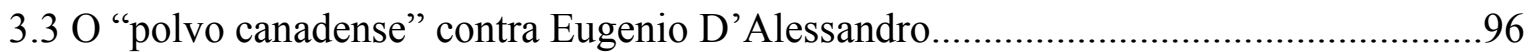

3.3.1 A greve de 1932 e a condenação do inimigo da Itália..............................................102

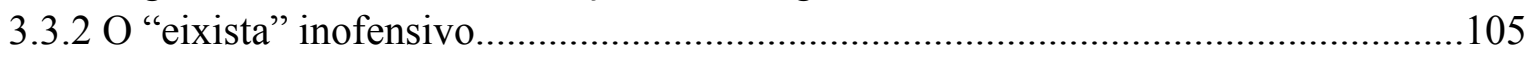

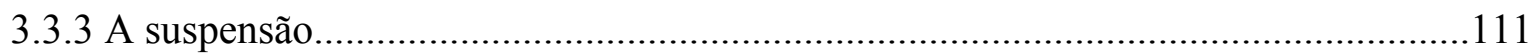

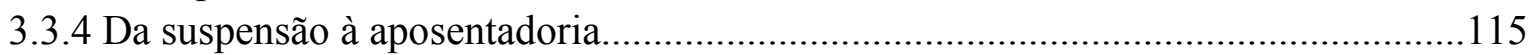

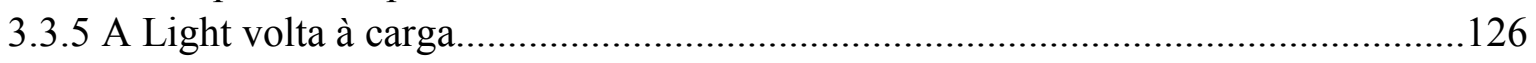

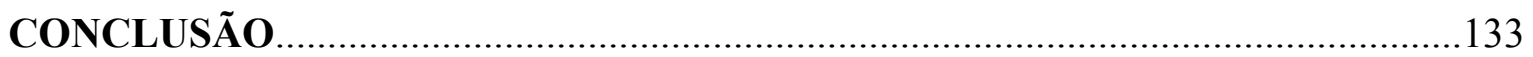

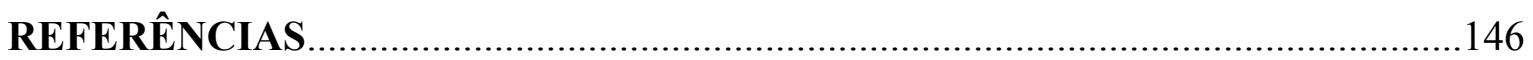

ANEXO A - Peças selecionadas do processo n. 1.370/1934 - “Eugenio D'Alessandro reclamada contra a Caixa de Aposentadorias e Pensões das Companhias Light, Jardim Botânico e S/A Du Gaz". 


\section{INTRODUÇÃO}

As obras dedicadas à história do direito do trabalho costumam dar pouca atenção à fase anterior à Consolidação das Leis do Trabalho, em especial à chamada fase ministerial (ou administrativa) da Justiça do Trabalho, bem como à transição para a fase exclusivamente jurisdicional da Justiça do Trabalho ${ }^{1}$.

O período iniciado com a criação do Conselho Nacional do Trabalho se encerra formalmente com a criação da Justiça do Trabalho dentro da estrutura do Poder Judiciário, mas certamente não se pode afirmar a inexistência de uma experiência de distribuição de justiça em matéria laboral e previdenciária produzida anteriormente, e aproveitada pelas Juntas de Conciliação e Julgamento e tribunais já na esfera do Poder Judiciário.

O ramo especializado em relações trabalhistas do Poder Judiciário recepcionou métodos, ideias, interpretações e modos de agir que já eram o reflexo de como a chamada questão social foi processada e sistematizada pela Justiça do Trabalho no período ministerial.

Concentrar a decisão dos conflitos trabalhistas no Poder Executivo foi uma decisão natural da política varguista sobre as relações de trabalho. Tratava-se de conter toda e qualquer possibilidade de conflito que pudesse impedir ou prejudicar o processo de industrialização em curso e, consequentemente, o projeto político traçado para o pós-1930. Contudo, as consequências dessa decisão não foram previamente medidas. Como se demonstrará mais adiante, um dos Ministros do Trabalho de Vargas, Alexandre Marcondes Filho, perceberia que o Estado não tinha condições materiais de estender seu controle até mesmo aos conflitos individuais trabalhistas, observação esta que pautou decisivamente a criação de órgãos propriamente jurisdicionais para o trato dos chamados dissídios individuais.

\footnotetext{
${ }^{1}$ Entende-se por fase administrativa o período em que os conflitos oriundos das relações de trabalho eram decididos por órgãos ministeriais, ligados ao Poder Executivo. A fase judicial ou jurisdicional corresponde ao período, que perdura até os dias de hoje, em que a competência para conhecer e julgar conflitos sobre relações de trabalho é de órgãos do Poder Judiciário. A terminologia é imprecisa, pois mesmo na fase administrativa os julgados eram levados à justiça comum para seu cumprimento forçado. Anteriormente à implantação da Justiça do Trabalho em 1941 era a justiça comum competente para conhecer os conflitos trabalhistas, muitas vezes por ela tratados pela ótica civil da locação de serviço. Sobre o tema, cf. LOPES, José Reinaldo de Lima. O direito na história: lições introdutórias. $2^{\mathrm{a}}$ ed. São Paulo: Max Limonad, 2002, p. 375, em que cita julgado do Tribunal de Justiça de São Paulo, de 1915, que é prova de que a "relação de trabalho ou era inserida na linguagem jurídica como relação contratual de locação de serviços ou sequer era considerada uma relação jurídica, mas uma simples continuação do regime servil”.
} 
O objetivo da presente dissertação é produzir, por meio da análise de processos, um retrato do funcionamento do sistema burocrático de distribuição de justiça em matéria trabalhista e previdenciária montado na estrutura do Poder Executivo, mais especificamente no Ministério do Trabalho, Indústria e Comércio, especialmente a partir de 1934, quando o Conselho Nacional do Trabalho passou a exercer função propriamente judicante. O recorte temporal do presente trabalho tem por termo final o ano de 1946, quando o Conselho Nacional do Trabalho dá lugar ao Tribunal Superior do Trabalho, já na esfera do Poder Judiciário.

Para isso, importa desvendar o desenho institucional do Conselho Nacional do Trabalho, a atuação dos conselheiros, as fontes doutrinárias a que recorriam, os personagens que gravitavam no seu entorno, todos dedicados ao manejo do sistema criado.

O presente trabalho baseia-se na crença de que há um viés pelo qual pode ser enxergada a invenção dos direitos sociais no Brasil. Tomando-se como um dado a regulação posta desde os anos 1920, e a intensificação havida após a Revolução de 1930, seja ou não por pressão de movimentos nascidos em meio ao operariado no início do século XX, parte dele constituído de mão de obra imigrante europeia, há que se analisar como o aparato burocrático composto pelo Conselho Nacional do Trabalho (e demais órgãos a ele vinculados) construiu as primeiras soluções jurídicas para o reconhecimento e o enforcement dos direitos sociais no Brasil, em especial os de índole trabalhista e previdenciária.

A colocação em movimento dos direitos sociais pelo CNT, pela doutrina e pelos demais atores relevantes mostram uma atuação efetiva dos órgãos de distribuição de justiça trabalhista, com elevada demanda pelos serviços por parte dos trabalhadores. As construções das soluções dos casos são as mais variadas, ora com remessa ao texto legal ora buscando os institutos propagados como fundamentais no arcabouço do "novo direito", tais como equidade, espírito da lei e vontade do legislador ${ }^{2}$.

É curioso notar na jurisprudência do Conselho Nacional do Trabalho que métodos de interpretação fortemente arraigados na sistemática do direito civil — em especial do direito das obrigações e dos contratos — tenham sido absorvidos como

\footnotetext{
${ }^{2}$ Paulo Macedo Garcia Neto aponta que a influência do arcabouço interpretativo constante da Lei de Introdução ao Código Civil criou um interessante paradoxo para o direito do trabalho brasileiro, uma vez que este, assim como outros ordenamentos laborais ocidentais, de forma mais ou menos aguda, constituíram-se como reações à regulação puramente privatística das relações de trabalho, em especial do trabalho subordinado, massificado, industrial (A questão social na Era Vargas entre a regulação de trabalho da CLT e os "fins sociais" da Lei de Introdução ao Código Civil. In: MOTTA, Carlos Guilherme; SALINAS, Natasha Schmitt Caccia (org.). Os juristas na formação do Estado-nação brasileiro: 1930 - dias atuais. São Paulo: Saraiva, 2010, p. 223-51).
} 
cânones "liberalizantes", de abertura do sistema ou de soltura das amarras do intérprete no direito do trabalho, que nasceu para mitigar e impor balizas firmes ao pacta sunt servanda.

Por isso, interessa expor uma história jurídico-política da regulação de relações de trabalho posta em ação na época, e não apenas uma descrição cronológica ou "evolutiva" de diplomas legais, projetos e promessas legislativas, ou, ainda, de movimentações sociais que pressionaram ou precipitaram uma decisão acerca dos rumos da contenção da questão social. Importa revelar como se dava o confronto entre o law in action e o law in books da época.

O relato das condições e do que foi produzido a partir do encontro dessas duas lógicas é relevante, pois nas Juntas, nos Conselhos Regionais e no Conselho Nacional do Trabalho foram gestadas as primeiras ideias e interpretações sobre o que seria e efetivamente passou a ser o direito do trabalho no Brasil.

Assim, a dissertação resta desenvolvida segundo quatro eixos principais.

O primeiro eixo corresponde à apresentação das principais teses e ideias que buscam compreender a construção dos direitos sociais no Brasil bem como o contexto socioeconômico da época, fundamentais para a compreensão dos motivos determinantes para o soerguimento de uma máquina burocrática de distribuição de justiça no âmbito das relações de trabalho. Por fim, será brevemente apresentado o diagnóstico sobre se e como tais ideias são reproduzidas nos principais manuais de direito do trabalho, maciçamente lidos e reproduzidos por profissionais do direito. Trata-se de uma forma de verificação da congruência entre a historiografia e a difusão da memória sobre o período.

Em seguida, passa-se no segundo eixo a uma descrição das mudanças no desenho institucional do Conselho Nacional do Trabalho ao longo do período estudado, de suas competências e limites de atuação.

O terceiro eixo corresponde à própria atividade do Conselho Nacional do Trabalho e dos órgãos a ele ligados (Ministério do Trabalho, Indústria e Comércio, Conselhos Regionais e Juntas de Conciliação e Julgamento), entendida como atividade judicante de distribuição de justiça em matéria de relações de trabalho. O capítulo resultante do desenvolvimento desse eixo contém uma análise de todos os processos do CNT levantados junto ao arquivo do Tribunal Superior do Trabalho, bem como de repertórios de jurisprudência do CNT, dos Conselhos Regionais e das Juntas. Além de uma análise de caráter mais geral, expôs-se também uma análise pormenorizada de um processo do CNT, em que a imbricação do contexto socioeconômico, das ideias em debate e dos personagens da época fica evidente. 
O quarto eixo contém as conclusões extraídas do trabalho de pesquisa e do desenvolvimento da dissertação.

A produção dos eixos ora descritos resultou, em sua maior parte, da consulta a fontes primárias, isto é, documentos da época produzidos pela própria burocracia do CNT bem como pelos atores que gravitavam em torno de seu funcionamento. Aqui cabe deixar um agradecimento à Coordenadoria de Gestão Documental e Memória do Tribunal Superior do Trabalho, na pessoa de Margarete Ferreira de Souza Brito. Os servidores da CGEDM são responsáveis pelo excelente trabalho de digitalização de todos os processos e documentos do Conselho Nacional do Trabalho, cuja qualidade pode ser comprovada no anexo à presente dissertação. Agradeço também aos servidores da Biblioteca Central da Faculdade de Direito da USP, pela atenção e pela paciência com minhas várias requisições de consulta a obras dos anos 1930 e 1940. Agradeço especialmente à servidora Guaraciaba de Barros Juk pela ajuda de valor inestimável no levantamento das fontes. Contei também com a valorosa ajuda do Diretor da Divisão de Acesso à Informação do Arquivo Público do Estado do Rio de Janeiro (APERJ), Johenir Janotti Viégas, no levantamento de processos da Delegacia Especial de Segurança Política e Social (DESPS), a polícia política varguista.

Para a adequada compreensão do capítulo quarto da presente dissertação, remete-se o leitor ao Anexo I, que contém as principais peças dos processos movidos por Eugenio D'Alessandro em face de The Rio de Janeiro Tramway Light and Power Company Limited a partir de 1934.

É preciso também observar que o presente trabalho constitui apenas um pequeno início do que pode vir a ser uma história do direito do trabalho brasileiro. Isto porque há diversas fontes e fatos a ele diretamente ligados que o escopo do presente trabalho não permitiu explorar. Cito aqui, apenas para exemplificar, os Congressos de Direito Social organizados pelo Professor Cesarino Junior à época, eventos pioneiros aos quais compareceram centenas de interessados nos estudos do direito social, além de vários personagens fundamentais para a compreensão do período.

No mais, ao longo do texto há outras indicação para a formação de uma possível agenda de pesquisa. 


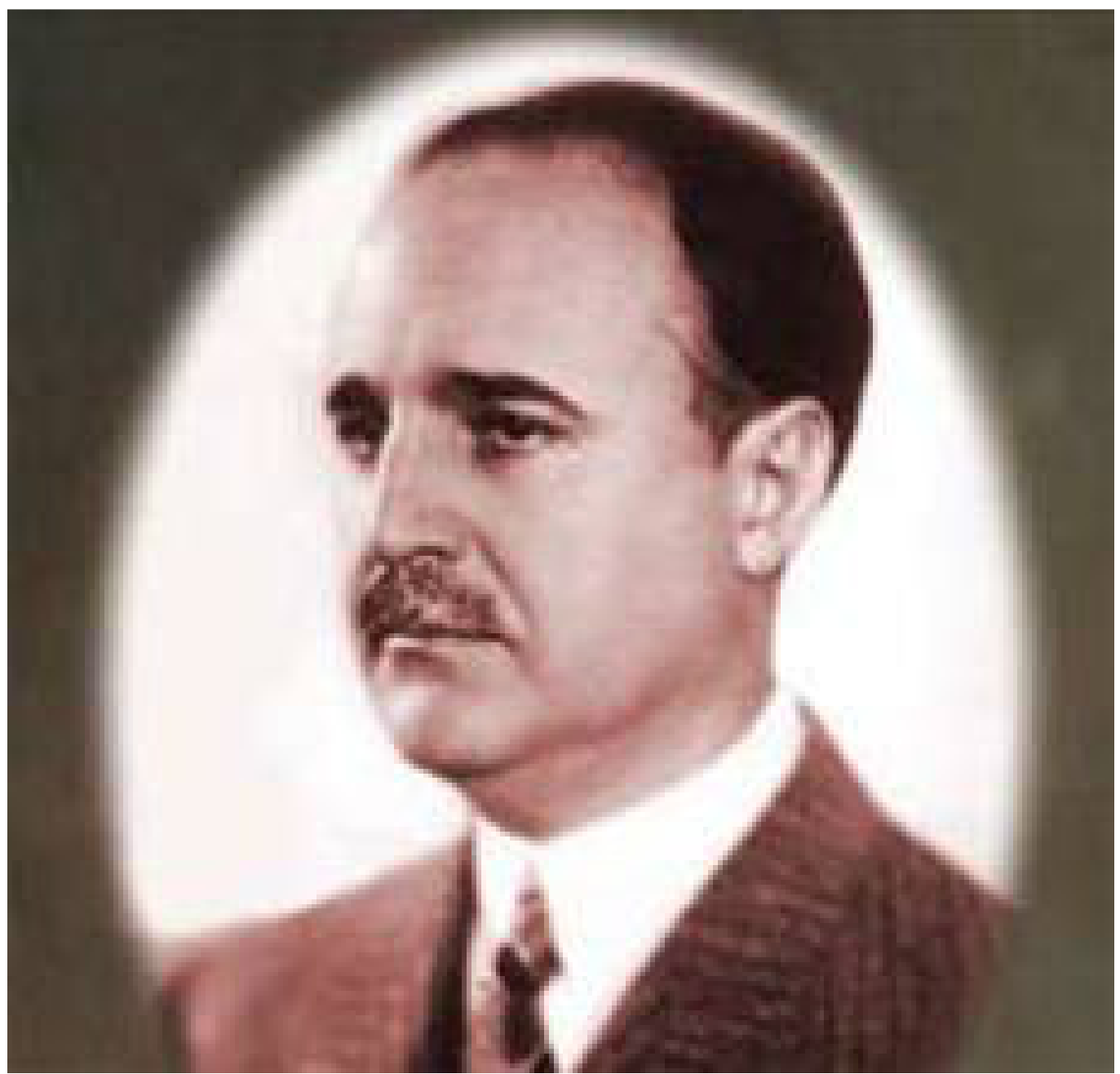

Fotografia 1 - Ministro Joaquim Pedro Salgado Filho 


\section{IDEIAS SOBRE A CONSTRUÇÃO DOS DIREITOS SOCIAIS NO BRASIL}

Há uma extensa historiografia que objetiva a análise dos fenômenos relacionados ao tratamento da "questão social" no Brasil, em especial sobre os efeitos da positivação da legislação trabalhista desde a Primeira República, intensificada durante a Era Vargas. Samuel Fernando de $\mathrm{Souza}^{3}$, em revisão da historiografia trabalhista, ressalta que por muito tempo os pesquisadores estiveram dedicados a explicar, por meio de uma exegese da legislação da época, como a máquina burocrática estatal teria se prestado a cercear a organização dos trabalhadores, por meio de sua repressão e cooptação. O patronato teria capturado o sistema desde o início, participando da própria formulação da legislação de proteção social. O atrelamento dos sindicatos ao Estado combinado com o excesso de procedimentos e requisitos legais teria provocado um enfraquecimento do movimento operário, inoperante diante da "domesticação" dos trabalhadores e da repressão aos grupos políticos anarquistas e comunistas ${ }^{4}$. Esse era o quadro até meados dos anos $1970^{5}$, em que o Decreto n. 19.770, de 19 de março de 1931 - destinado a regular a sindicalização e colocá-la próxima do Estado -, era apontado pelos estudiosos como o ponto central da compreensão do trabalhismo varguista.

A exceção, ainda nos anos 1970, fica por conta de Luiz Werneck Vianna ${ }^{6}$, que superou a análise exclusiva da questão sindical para avançar no exame da regulamentação de outros aspectos do mundo do trabalho, como férias, trabalho de menores, aposentadoria, bem como da Justiça do Trabalho, mas ainda com foco nos textos legais. Além disso,

\footnotetext{
${ }^{3}$ A descrição da bibliografia produzida desde meados da década de 1970, aqui aproveitada em suma e somada a outras referências, está em SOUZA, Samuel Fernando de. Coagidos ou subornados: trabalhadores, sindicatos, Estado e leis do trabalho nos anos 1930. 2007. 228 f. Dissertação de Doutorado Instituto de Filosofia e Ciências Humanas, Universidade de Campinas, 2007, pp. 12-21. Disponível em: < http:// cutter. unicamp.br /document/ ?code $=$ vtls000436523>. Acesso em: 16 novembro 2011.

${ }^{4}$ Sobre a atuação dos anarquistas e comunistas v. GOMES, Angela de Castro. A invenção do trabalhismo. $3^{\text {a }}$ ed. Rio de Janeiro: Editora FGV, 2005, especialmente itens II e III da primeira parte.

5 Samuel Fernando de Souza cita os seguintes trabalhos do período anterior a meados de 1970: RODRIGUES, José Albertino. Sindicato e desenvolvimento no Brasil. São Paulo: Difusão Europeia do Livro, 1966; SIMÃO, Aziz, Sindicato e Estado. São Paulo: Dominus, 1966; RODRIGUES, Leôncio Martins. Industrialização e atitudes operárias. São Paulo: Brasiliense, 1970. Com o mesmo viés dos trabalhos pré-1970 cf. SILVA, Zélia Lopes da. A domesticação dos trabalhadores nos anos 30. São Paulo: Marco Zero/CNPq, 1990.

${ }^{6}$ Liberalismo e Sindicato no Brasil. Rio de Janeiro: Paz e Terra, 1976.
} 
Werneck Vianna identificou em Oliveira Vianna a criação e a propagação de uma “ideologia da outorga" da legislação trabalhista por Vargas ${ }^{7}$.

O olhar para além da letra da lei viria no final dos anos 1970, com os trabalhos de Angela de Castro Gomes ${ }^{8}$, Marisa Saenz Leme ${ }^{9}$ e Maria Barbosa de Araújo ${ }^{10}$. O trabalho seminal de Gomes, em abono das conclusões de Luiz Werneck Vianna, afastou a interpretação até então corrente segundo a qual a origem de toda a regulação das relações de trabalho no Brasil estaria em 1930, com a ascensão de Getúlio Vargas ao poder. A autora mostrou a participação de industriais e comerciantes nas discussões relativas à edição e à implementação de diversos diplomas legislativos, incluindo as leis de acidentes de trabalho de 1917 a 1919, o Projeto n. 284 de um Código do Trabalho e a atuação do Ministério do Trabalho, Indústria e Comércio na década de 1930. O trabalho de Marisa Leme, à sua vez, permitiu também a identificação detalhada de quais eram os grupos e atores sociais envolvidos nas disputas sobre a regulamentação e a efetivação dos direitos trabalhistas e previdenciários após 1930. Já a pesquisa de Barbosa de Araújo resultou num rico detalhamento das variadas inspirações europeias da legislação trabalhista, afastando a ideia da absorção monolítica do modelo italiano da Carta del Lavoro.

Questionada a ideia do controle centralizado por parte do Estado ficaram abertos os caminhos para estudos sobre o papel dos sindicatos, sobre as específicas movimentações patronais bem como sobre as demandas individuais dos trabalhadores perante as instituições. A partir deste estado de coisas foram selecionadas três construções teóricas que refletem achados fundamentais sobre a natureza das relações entre Estado e trabalhadores e que explicitam os motivos da emergência da chamada questão social no Brasil no início do século XX.

\section{$1.1 \mathrm{O}$ mito da outorga}

\footnotetext{
${ }^{7}$ Oliveira Vianna, segundo Werneck Vianna (Liberalismo e sindicato no Brasil. Rio de Janeiro: Paz e Terra, 1976), propôs e consagrou a tese da outorga da proteção social por parte do Estado, minimizando as pressões operárias que vinham se avolumando. Oliveira Vianna expos que a legislação do trabalho teria sido resultado de "outorga generosa dos dirigentes políticos e não de uma conquista realizada pelas classes trabalhadoras" (Direito do trabalho e democracia social. Rio de Janeiro: José Olimpio, 1945).

${ }^{8}$ Burguesia e trabalho: política e legislação social no Brasil 1917-1937. Rio de Janeiro: Campus, 1979.

${ }^{9}$ A ideologia dos industriais brasileiros (1919-1945). Petrópolis: Vozes, 1978.

${ }^{10}$ O batismo do trabalho: a experiência de Lindolfo Collor. Rio de Janeiro: Civilização Brasileira, 1981. O prefácio, redigido por Evaristo de Moraes Filho, contém uma defesa do Decreto n. 19.770/1931, concebido por seu pai, o socialista Evaristo de Moraes.
} 
A ideia segundo a qual o princípio de todo o sistema de proteção social brasileiro seria a chegada de Vargas ao poder após a Revolução de 1930, momento a partir do qual o presidente teria fundado um Estado Nacional com base em um conjunto de direitos sociais - trabalhistas e previdenciários - concedido graciosamente ao povo, é bastante difundida não só pelo senso comum, mas de certa forma também por trabalhos historiográficos sobre o período, como já visto. Dentre os vários mitos sobre a fundação do Brasil presentes no imaginário popular a ideologia da outorga aparece como um dos mais fortes, talvez tão difundido quanto o retrato de uma cena heroica e revolucionária - "O Grito do Ipiranga", de Pedro Américo -, em que teria ocorrido a proclamação da independência do Brasil ${ }^{11}$.

Se é certo que houve uma maciça produção de leis, decretos e decretos-lei destinados a dar corpo a um sistema de proteção e controle no âmbito das relações de trabalho a partir de 1930, também é certo que este não é o marco inicial das preocupações com a questão social, que vinham se avolumando pelo menos desde o início do século. Antes ainda das leis de acidentes de trabalho de 1917 e 1919, houve a edição de um conjunto de regras que permitia a sindicalização de rurícolas (Decreto n. 979, de 6 de janeiro de 1903) e, posteriormente, haveria ainda a própria criação do Conselho Nacional do Trabalho em 1923. No mesmo ano veio a Lei Elói Chaves, por meio da qual foi criada a Caixa de Aposentadorias e Pensões dos Ferroviários e garantida a estabilidade decenal à categoria. Em 1926, a garantia da estabilidade decenal foi estendida a marítimos e portuários $^{12}$.

\footnotetext{
${ }^{11}$ Angela de Castro Gomes cita em seu Burguesia e trabalho: política e legislação social no Brasil 19171937 (Rio de Janeiro: Campus, 1979, p. 45) uma entrevista de Raimundo Faoro a Veja, publicada na edição n. 399, de 28/04/1976: "VEJA - E essa 'colonização' [do Estado, expressão usada por Faoro em resposta à questão anterior] consistiu em que o Estado brasileiro soube desenvolver mecanismos capazes de neutralizar as tensões sociais? FAORO - Mais do que isso: o Estado consegue até antecipar-se a elas. A legislação trabalhista, por exemplo, foi adotada antes mesmo que fosse uma exigência premente dos operários. Assim, por saber antecipar-se às reivindicações sociais, o Estado pôde exercer sobre os trabalhadores um controle político muito maior do que se tivesse promulgado aquela legislação sob pressão. Dando antes que lhe peçam ou obriguem, o Estado acaba com a possibilidade de que as forças sociais insatisfeitas se organizem politicamente." Disponível em: <http://veja.abril.com.br/acervodigital/>. Acesso em 18 dez 2012.

${ }_{12}$ À propósito, conferir CARVALHO, José Murilo de. Pontos e Bordados: escritos de história e política. Belo Horizonte: Editora UFMG, 2005, p. 283. "A situação do País se revela mais peculiar se observarmos que os direitos sociais, os últimos na seqüência clássica, expandiram-se antes dos direitos políticos no Brasil. Foram introduzidos não graças à luta política, mas durante um período de ditadura. Não se nega que antes da Revolução de 30 houvesse um movimento operário e demandas de regulamentação do trabalho e de política de assistência social. Mas é um fato também que a legislação social foi introduzida maciçamente num momento em que não estavam em operação mecanismos representativos. Por isto, foi introduzida de cambulhada com uma política sindical que favorecia o controle estatal sobre as organizações operárias. Deste movimento surgiu o mito da doação das leis trabalhistas pelo Estado, particularmente por seu executivo na época, Getúlio Vargas. A imagem paternalista de 'pai dos pobres' por longos anos conformou a consciência
} 
Angela de Castro Gomes antecipa já na introdução ao seu Burguesia e Trabalho a superação da ideologia da outorga como resultado de seus estudos:

"[E]mbora concordemos que os anos trinta sejam o ponto culminante deste processo, pois é o período em que a maioria absoluta das leis sociais são promulgadas e de fato entram em vigor, não quisemos restringir-nos a este momento pelas razões que se seguem.

Em primeiro lugar, por que verificamos, logo no início de nossos estudos, que a compreensão dos termos de discussão do problema teria que estar referida a todo um período anterior no qual o assunto vinha sendo levantado e debatido. Seu abandono poderia conduzir-nos a subestimar e/ou ignorar toda uma intensa atuação, tanto do operariado, quanto do empresariado face à questão, o que evidentemente só beneficiaria a perspectiva que destaca o papel 'pioneiro' do Estado no pós-trinta.",13

Outro elemento presente na ideologia da outorga é o caráter antecipatório do Estado pós-revolucionário que, antevendo as necessidades dos trabalhadores da indústria em expansão, teriam rapidamente engendrado um sistema legislativo de proteção social, destinado a prevenir conflitos e colocar a classe trabalhadora sob controle. Por esta visão, o Brasil teria antes organizado um corpo de legislação social moderna, abrangente e "avançada" antes mesmo de se verificar a existência de um desenvolvimento industrial significativo e de um proletariado robusto. Esta perspectiva desconsidera a movimentação reivindicatória do operariado, os debates travados no meio empresarial e a atuação dos grupos de pressão junto ao Congresso Nacional desde a Primeira República. Além disso, é pouco verossímil que conflitos não observados no nível da realidade social viessem a merecer alguma atuação em âmbito político, por meio de um trabalho em bases hipotéticas. Daí decorre a ideia de um movimento operário acomodado, inerte, burocratizado, derrotado e dependente de um Estado paternalista.

Quanto ao empresariado urbano, é certo que não se lhe pode atribuir posição hegemônica no processo de implantação do sistema de proteção social, fruto do atraso no processo de sua modernização e do bloqueio do acesso a uma política partidária baseada no mandonismo local das oligarquias agrárias. Contudo, à falta de uma posição hegemônica não corresponde uma incapacidade de participação política ou a ausência de concepções e projetos sobre a realidade social. Luiz Werneck Vianna ${ }^{14}$ buscou refutar o argumento

operária, assim como o corporativismo se enraizou profundamente na prática sindical de patrões e operários. Tudo isto era e é, sintoma do reforço da precariedade da cidadania, da ausência da conquista dos direitos individuais e coletivos pela luta."

${ }^{13}$ GOMES, Angela de Castro. Burguesia e trabalho: política e legislação social no Brasil 1917-1937. Rio de Janeiro: Campus, 1979, p. 26.

${ }^{14}$ Liberalismo e Sindicato no Brasil. Rio de Janeiro: Paz e Terra, 1976, cap. III. 
bastante presente na historiografia brasileira segundo o qual os setores do comércio e da indústria estariam politicamente submetidos à tradicional elite econômica agrária durante o período inicial do processo de industrialização no Brasil. A ordem liberal oligárquica não impediu o desenvolvimento de uma burguesia urbana industrial com interesses específicos os quais buscou efetivar, embora sempre se ajustando aos limites da ordem oligárquica. E se a atuação por meio dos partidos não estava acessível, foi nas entidades setoriais que o empresariado encontrou sua via de comunicação com o Estado ${ }^{15}$.

Constatando que a posição de passividade do patronato também integra a ideologia da outorga, Angela de Castro Gomes propõe um caminho para sua desconstrução:

\begin{abstract}
"Portanto, quando através do estudo da questão da regulamentação do trabalho no Brasil procuramos a posição dos setores empresariais, estamos justamente propondo que a compreensão de problemas deste tipo dependem de uma visão interativa entre Estados e classes sociais, não se podendo privilegiar um dos lados da questão: o da 'doação' do Estado ou o da 'conquista' da classe. Desta forma, a crítica ao mito da submissão política do empresariado recoloca este ator em cena, na medida em que procura ressaltar a singularidade de sua participação política"16.
\end{abstract}

Todavia, a ideologia da outorga não é resultado apenas de trabalhos de pesquisa que privilegiaram atores isolados ou assumiram premissas e perspectivas parciais para o seu desenvolvimento. O mito da outorga resulta também - e talvez principalmente do empenho aplicado em sua difusão pelo próprio governo varguista, antes de qualquer análise histórica ou sociológica distanciada sobre o período. O mito da outorga foi sendo paulatinamente construído desde o Governo Provisório, sendo maciçamente difundido a partir do Estado Novo pela máquina propagandística colocada à disposição do governo de Vargas. As palestras radiofônicas do Ministro do Trabalho, Indústria e Comércio, Alexandre Marcondes Filho, eram claras, didáticas, estrategicamente repetitivas e emocionais, e sintetizavam as propostas que compunham o projeto político representado pelo Estado Novo. Angela de Castro Gomes, em A Invenção do Trabalhismo, analisou os pronunciamentos de Marcondes Filho, apontando a sofisticação do discurso por trás da ideologia da outorga e sua íntima relação com a questão social:

\footnotetext{
15 Para o quanto discutido nos dois parágrafos anteriores cf. GOMES, Angela de Castro. Burguesia e trabalho: política e legislação social no Brasil 1917-1937. Rio de Janeiro: Campus, 1979, pp. 47-51 e cap. $\mathrm{V}$.

${ }^{16}$ GOMES, Angela de Castro. Burguesia e trabalho: política e legislação social no Brasil 1917-1937. Rio de Janeiro: Campus, 1979, p. 48.
} 
"As falas de Marcondes, bem como os artigos da revista Cultura Política e inúmeros outros textos políticos do período estruturavam-se basicamente em torno da construção de uma relação entre o povo e o Estado/Nação, encarnado na figura do presidente. Esta relação se dava primordialmente através da execução do objetivo precípuo e definidor da Revolução de 1930, realizada pelo Estado Nacional a partir de 1937. A história da relação povo/presidente era fundamentalmente a história da resolução da questão social no Brasil, questão que, ignorada até a década de 30, manchava nossa tradição republicana e impedia qualquer tipo de contato real entre governantes e governados. Portanto, quando o discurso revolucionário pós-37 foi buscar sua origem em 30 e definiu-se pelo ideal de justiça social, ele coerentemente estava desenhando o círculo que continha 'o' entendimento da política brasileira.

A relação que fundava o Estado era aquela entre o povo e o presidente, que legislou sobre o problema síntese da nacionalidade: o problema social. Porém, o que o discurso punha em relevo particularmente era a forma como a questão foi resolvida, o que acabava por determinar a forma pela qual a relação povo/presidente se efetuava. Neste sentido, seu ponto nodal estava na construção do que se convencionou chamar na literatura sobre questão social 'ideologia da outorga'. Ou seja, a legislação social brasileira, instrumento mediador por excelência das relações entre governantes e governados, foi outorgada pela personalidade clarividente do chefe do Estado ao seu povo. A relação fundadora do Estado era uma relação de doação, uma relação de dar e receber dádivas/presentes/benefícios." 17

O ato desinteressado e gratuito de doação do corpo de legislação trabalhista foi assim interpretado por Angela de Castro Gomes:

"É inegável que a lógica material olsoniana de cálculo de custos e benefícios estava aí em vigência. Os benefícios da legislação social eram efetivamente transformados em 'incentivos seletivos', uma vez que a condição de sindicalizado era essencial para seu usufruto. Entretanto, neste momento, esta lógica não foi um recurso de poder suficiente para afastar as reações. $\mathrm{O}$ uso da repressão ao movimento sindical foi então uma arma fundamental, como bem previu e, a partir de 1935, pôs em prática o ministro Agamenon Magalhães.

Esta lógica material, essencial para a construção de um pacto social, na realidade só começou a produzir os significativos resultados a ela imputados no pós-40. A partir daí ela combinou-se com a lógica simbólica do discurso trabalhista, que, ressignificando a 'palavra operária' construída ao longo da Primeira República, apresentava os benefícios sociais não como uma conquista ou uma reparação, mas como um ato de generosidade que envolvia reciprocidade. Nesta perspectiva, o Estado não era visto apenas como produtor de bens materiais, mas como produtor de um discurso que tomava elementos-chave da auto-imagem dos trabalhadores e articulava demandas, valores e tradições desta classe, redimensionando-os em outro contexto. A classe trabalhadora, por

${ }^{17}$ GOMES, Angela de Castro. A invenção do trabalhismo. $3^{\text {a }}$ ed. Rio de Janeiro: Editora FGV, 2005, pp. 226-33. Trabalho apresentado como tese de doutorado da autora ao IUPERJ em 1987, pp. 226-7. 
conseguinte, só 'obedecia' se por obediência política ficar entendido o reconhecimento de interesses e a necessidade de retribuição. Não havia, neste sentido, mera submissão e perda de identidade. Havia pacto, isto é, uma troca orientada por uma lógica que combinava os ganhos materiais com os ganhos simbólicos da reciprocidade, sendo que era esta segunda dimensão que funcionava como instrumento integrador de todo $o$ pacto." $" 18$

Se leis e debates já havia e se o que foi "outorgado" não o foi sem interesse, resta da ideologia senão a dimensão mítica e uma forte perpetuação no discurso político ao longo do tempo, o que não é pouco. Como já apontado, a historiografia brasileira sobre as relações de trabalho vem se dedicando ao menos desde o fim dos anos 1970 à desconstrução do mito, por meio da pesquisa do papel dos atores relevantes no período sindicatos, trabalhadores, instituições, políticos - e também da legislação trabalhista posta em ação nas Juntas e Comissões Mistas de Conciliação e Julgamento, Conselhos Regionais do Trabalho, Conselho Nacional do Trabalho e, a partir dos anos 1940, os órgãos da Justiça do Trabalho. E tem sido bem sucedida nessa tarefa.

Mais recentemente, nos anos 1990, a análise de processos por meio dos quais os trabalhadores pleiteavam o cumprimento do conjunto de direitos sociais positivados ingressou na agenda da pesquisa historiográfica. Em 1995, Fernando Teixeira da Silva ${ }^{19}$ mostrou como os patrões do Porto de Santos foram submetidos à legislação trabalhista e os resultados positivos para os "doqueiros" de um conjunto de processos movidos por empregados nas cortes trabalhistas, destinados à solução de alguns conflitos de interesses. Jairo Queiroz Pacheco ${ }^{20}$, em sua pesquisa sobre os operários têxteis em Juiz de Fora, no estado de Minas Gerais enumerou as estratégias das empresas no sentido de impedir a aplicação efetiva da legislação dentro das fábricas, sendo uma delas a demissão dos operários que tomassem parte nas reclamações contra seus patrões na Justiça do Trabalho. Rinaldo José Varussa ${ }^{21}$ consultou processos da Junta de Conciliação e Julgamento de Jundiaí-SP durante as décadas de 1940 a 1960, entre outras fontes, para compreender como os empregados, advogados e funcionários da Junta articulavam os conceitos de direito, lei e justiça, concluindo que o sucesso de colegas de trabalho perante a Justiça do Trabalho, a

\footnotetext{
${ }^{18}$ GOMES, Angela de Castro. A invenção do trabalhismo. $3^{\text {a }}$ ed. Rio de Janeiro: Editora FGV, 2005, pp. 180.

${ }^{19}$ SILVA, Fernando Teixeira da. A carga e a culpa - Os operários das docas de Santos: direitos e cultura de Solidariedade (1937 - 1968). São Paulo/Santos: Hucitec/Prefeitura Municipal de Santos, 1995.

${ }^{20}$ Guerra na fábrica: cotidiano operário fabril durante a segunda guerra - o caso de Juiz de Fora - MG. Dissertação de Mestrado. São Paulo: USP, 1996.

${ }^{21}$ Legislação e Trabalho: experiências de trabalhadores na Justiça do Trabalho (Jundiaí-SP, décadas de 1940 a 1960). Tese de Doutorado. São Paulo: PUC, 2002.
} 
pressão dos sindicatos e o porte das empresas eram variáveis que entravam no cálculo subjetivo dos trabalhadores quando decidiam recorrer à Justiça do Trabalho.

Os processos do Conselho Nacional do Trabalho, de 1923 a 1933, foram objeto da pesquisa de Samuel Fernando de Souza ${ }^{22}$, que também recorreu a fontes relativas aos serviços de fiscalização do trabalho (Inspetorias do Trabalho), de modo a possibilitar uma comparação das duas formas de aplicação da legislação social ("contenciosa" e "fiscal"), destacando que a articulação das demandas dos trabalhadores perante o CNT revela uma elevada consciência legal por parte destes.

\subsection{Cidadania por meio da legislação trabalhista}

Já no âmbito da ciência política, há uma importante e célebre tese que vincula o desenvolvimento da cidadania no Brasil ao advento de um corpo de legislação trabalhista, formulada por Wanderley Guilherme dos Santos ${ }^{23}$. A expressão “cidadania regulada", cunhada por Santos, designa o conjunto argumentativo de grande capacidade explicativa sobre o processo de inclusão cidadã por meio do desenvolvimento dos direitos no Brasil, sobretudo trabalhistas, de 1930 até 1988.

Santos apresenta os elementos da teoria da cidadania regulada em três de suas obras. A expressão é utilizada pela primeira vez em livro de 1979, Cidadania e Justiça: a política social na ordem brasileira ${ }^{24}$. Em 1998, o autor lança o livro Décadas de Espanto e uma Apologia Democrática ${ }^{25}$, em que reafirma o conceito de cidadania regulada, aplicando-o a um período estendido em relação àquele analisado no primeiro estudo, com

\footnotetext{
22 SOUZA, Samuel Fernando de. Coagidos ou subornados: trabalhadores, sindicatos, Estado e leis do trabalho nos anos 1930. 2007. 228 f. Dissertação de Doutorado - Instituto de Filosofia e Ciências Humanas, Universidade de Campinas, 2007, pp. 12-21. Disponível em: < http:// cutter. unicamp.br /document/ ?code = vtls000436523>. Acesso em: 16 novembro 2011.

23 Aproveito neste item a síntese da tese da cidadania regulada apresentada por Teresa Cristina de Souza Cardoso Vale em artigo crítico ao conceito e às conclusões apresentados por Wanderley Guilherme dos Santos. Cf. VALE, Teresa Cristina de Souza Cardoso. Cidadania regulada: uma exploração crítica do conceito. In: $6^{\circ}$ Encontro da ABCP, 2008, Campinas. Anais do $6^{\mathbf{0}}$ Encontro da ABCP, 2008. Disponível em: < http://cienciapolitica.servicos.ws/abcp2008/arquivos/22_7_2008_14_35_42.pdf >. Acesso em 19 mai 2011. O artigo foi elaborado a partir de tese de mestrado apresentada no IUPERJ em dezembro de 2004 com o mesmo título.

${ }^{24}$ Foi consultada a $2^{\text {a }}$ edição, de 1987: SANTOS, Wanderley Guilherme dos. Cidadania e justiça: a política social na ordem brasileira. $2^{\text {a }}$ ed. Rio de Janeiro: Campus, 1987.

25 SANTOS, Wanderley Guilherme dos. Décadas de Espanto e uma Apologia Democrática. Rio de Janeiro, Editora Rocco, 1998.
} 
base em dados atualizados. Em ensaio lançado em 1985, A Pós-“Revolução” Brasileira ${ }^{26}$, o autor volta a fazer uso da expressão.

Para o autor, a cidadania regulada é um

"conceito de cidadania cujas raízes encontram-se, não em um código de valores políticos, mas em um sistema de estratificação ocupacional. (...) [S]ão cidadãos todos aqueles membros da comunidade que se encontram localizados em qualquer uma das ocupações reconhecidas e definidas em lei" ${ }^{27}$.

Dessa forma a cidadania seria paulatinamente ampliada

"via regulamentação de novas profissões e/ou ocupações e mediante ampliação do escopo dos direitos associados a estas profissões e não por expansão dos valores inerentes ao conceito de membro da comunidade" 28 .

Observando a lógica varguista, posta em prática no começo dos anos 1930 e continuada no Estado Novo, segundo a qual "quem tem ofício, tem benefício" 29 , Santos percebe o estabelecimento de uma cidadania no Brasil, embora ainda restrita aos trabalhadores com carteira de trabalho e sindicalizados, meios formais e oficiais de reconhecimento do pertencimento do indivíduo ao mundo do trabalho. Os trabalhadores rurais, por exemplo, eram considerados protocidadãos, dado que a regulamentação de suas atividades não foi concomitante à do trabalho urbano no Brasil.

Nesse sentido, para o autor, a cidadania no Brasil até 1988 não partia de um código de valores políticos, mas sim de um sistema de estratificação ocupacional, em que os direitos dos cidadãos decorrem dos direitos associados aos estatutos profissionais que, por sua vez, só existem a partir do advento de uma disciplina para a atividade em lei. A carteira de trabalho, segundo esse raciocínio, mais do que apenas um documento de registros trabalhistas de seu portador, passa a ser uma certidão de nascimento cívico, um contrato entre indivíduo e Estado, com cláusula de outorga de cidadania.

\footnotetext{
${ }^{26}$ SANTOS, Wanderley Guilherme dos. A Pós-“Revolução” Brasileira. In: FRANCO, Afonso Arinos de Melo. Brasil, Sociedade Democrática. Rio de Janeiro, Editora José Olympio, 1985.

${ }^{27}$ SANTOS, Wanderley Guilherme dos. Cidadania e justiça: a política social na ordem brasileira. $2^{\mathrm{a}}$ ed. Rio de Janeiro: Campus, 1987, p. 68; e, SANTOS, Wanderley Guilherme dos. Décadas de Espanto e uma Apologia Democrática. Rio de Janeiro, Editora Rocco, 1998, p. 103.

${ }^{28}$ Wanderley Guilherme dos. Décadas de Espanto e uma Apologia Democrática. Rio de Janeiro, Editora Rocco, 1998, p. 103.

${ }^{29}$ Sobre o tema cf. GOMES, Angela de Castro. A invenção do trabalhismo. $3^{\text {a }}$ ed. Rio de Janeiro: Editora FGV, 2005, cap. IV, em especial o item 2 "If friends make gifts, gifts make friends".
} 
Para Wanderley Guilherme dos Santos, a ordem regulada põe fim a um período laissezfairiano no Brasil, e é com a ordem regulada que se diminui a distância entre equidade e acumulação. A acumulação teria motivado a regulamentação do trabalho no Brasil. A especificação das categorias profissionais e a delimitação de seus papéis para o processo de crescimento determinou e sinalizou as diferenças entre os salários. A equidade, a seu turno, aparecia na distribuição de benefícios proporcionais à contribuição já realizada dentro do sistema, sendo que os programas sociais buscavam convergências entre a política de bem-estar e as variações no nível de riqueza.

A força da tese resta demonstrada pelo autor por meio da identificação das pressões dos setores sociais pela regulamentação profissional de suas ocupações. A reiteração dos movimentos pelo reconhecimento e pela especificação de direitos particulares inerentes a um dado ofício apontam para a internalização da cidadania regulada na cultura cívica brasileira. $\mathrm{O}$ desmanche da ordem regulada vigente se deu a partir de 1978, período em que o "novo sindicalismo" passa a questionar os termos de sua relação com o Estado.

José Murilo de Carvalho, talvez percebendo a capacidade explicativa do conceito de Santos, cunhou o neologismo estadania, no livro Os Bestializados ${ }^{30}$, com ele designando a centralidade do Estado em relação aos cidadãos, por ele seletivamente cooptados, uma vez que buscavam dele obter o acesso a bens e interesses privados ${ }^{31}$. Nessa perspectiva, a estadania se define pela participação de alguns grupos específicos no aparato estatal, tais como os militares, o funcionalismo público em geral e alguns setores do operariado. Para Carvalho, o brasileiro comum nunca teve cidadania. No máximo, depois da Revolução de 1930, experimentou a estadania, isto é, uma incorporação ao sistema político pelo envolvimento na malha crescente da burocracia estatal ${ }^{32}$. O autor procurou também demonstrar, em escrito posterior, que o caso brasileiro é distinto do inglês pela maior relevância dos direitos sociais bem como pelo fato de o seu advento ter precedido historicamente a consolidação dos direitos civis e políticos, até mesmo deles tendo prescindido num primeiro momento ${ }^{33}$.

\footnotetext{
${ }^{30}$ CARVALHO, José Murilo de. Os bestializados: o Rio de Janeiro e a república que não foi. $3^{\text {a }}$ ed. São Paulo: Companhia das Letras, 1987, p. 50.

${ }^{31}$ CARVALHO, José Murilo de. Cidadania: tipos e percursos. Estudos Históricos, Rio de Janeiro, $\mathrm{n}^{\circ} 18$, 1996.

${ }^{32}$ CARVAlHO, José Murilo de. Cidadania, estadania e apatia. In: Jornal do Brasil, 24 jun 2001, p. 8.

${ }^{33}$ CARVALHO, José Murilo de. Cidadania no Brasil: o longo caminho. $15^{\text {a }}$ ed. Rio de Janeiro: Civilização Brasileira, 2012. O caso brasileiro teria contrariado o modelo marshalliano (MARSHALL, Thomas Humphrey. Cidadania, classe social e status. Rio de Janeiro: Zahar, 1967), segundo o qual na Inglaterra houve uma ordem de precedência dos direitos civis e políticos sobre os direitos sociais.
} 
Para o escopo do presente trabalho importa observar que ambas as teses apontam para a necessidade de análise do processamento intraburocrático da efetivação dos direitos sociais na ordem política varguista, ainda que tenham premissas e conclusões distintas.

\subsection{Capitalismo tardio e demanda por mão de obra}

Mais uma evidência - não proveniente de estudos predominantemente historiográficos - de que não houve qualquer antecipação das soluções para os conflitos em torno da questão social no início dos anos 1930 é trazida pela ótica do capitalismo tardio, interpretação da industrialização brasileira segundo a qual o desenvolvimento industrial brasileiro advém da evolução do capitalismo no Brasil.

De acordo com essa escola de pensamento, a acumulação de capital industrial ocorreu concomitantemente à acumulação de capital no setor exportador cafeeiro nos períodos de expansão das exportações ${ }^{34}$. A ótica do capitalismo tardio refuta o caráter reflexo atribuído às economias da América Latina pela doutrina da $\mathrm{Cepal}^{35}$, sugerindo que a transição para a economia capitalista exportadora dependente da procura externa, operada entre o fim da década de 1880 e a de 1920, deu origem e consolidou o capitalismo industrial brasileiro. Nesse período a acumulação de capitais proporcionada pelos ganhos de escala trazidos pelo maquinário de beneficiamento de café e pelo advento da malha ferroviária aumentou a procura por mão de obra. A escassez desta e a onerosidade do trabalho escravo, também causada pelas pressões pelo fim da escravidão, levaram ao incentivo à imigração de trabalhadores livres. Foi esta consolidação de uma economia

\footnotetext{
${ }^{34}$ A descrição da teoria do capitalismo tardio aqui exposta é baseada na resenha formulada por Wilson Suzigan em Indústria brasileira: origem e desenvolvimento. Nova edição. São Paulo: Hucitec/Editora da Unicamp, 2000, pp. 23-24 e 34-41. A edição original esgotada foi publicada em 1986 pela Editora Brasiliense. Suzigan discute no livro a congruência das evidências empíricas com as interpretações da industrialização brasileira.

35 “A base da doutrina da Cepal reside no padrão de relações de comércio exterior entre os países do centro (industrializados) e os países da periferia (América Latina). Esse padrão, segundo o argumento, criou uma divisão internacional do trabalho que impôs aos países da periferia a especialização na produção de produtos primários para exportação para os países do centro, os quais, por sua vez, supriam de produtos manufaturados os países da periferia. Nessa divisão internacional do trabalho, o padrão de crescimento dos países periféricos era 'voltado para fora', isto é, o setor exportador era predominante no processo de crescimento da renda interna, com a procura externa funcionando como o 'motor do crescimento'. Nos termos da economia política da Cepal, o 'centro de decisão' da economia dos países periféricos ficava fora desses países, caracterizando-se como economias 'reflexas e dependentes'." SUZIGAN, Wilson. Indústria brasileira: origem e desenvolvimento. Nova edição. São Paulo: Hucitec/Editora da Unicamp, 2000, p. 26.
} 
capitalista exportadora de café que criou as condições favoráveis para o transbordamento de capitais para o setor industrial.

Daí importa reter que houve a formação de um mercado de trabalho livre, combinado com a criação de um mercado interno para produtos industrializados e a ampliação da capacidade de importar bens de salário, matérias-primas e maquinaria. A emergência da questão social no Brasil no início do século XX é praticamente simultânea a esse fenômeno de constituição de um setor industrial no Brasil, o que serve à refutação do caráter antecipatório da política de relações de trabalho varguista ${ }^{36}$.

\subsection{As ideias sobre a construção dos direitos sociais e a reprodução da memória em obras jurídicas}

Afinal, aos esforços da historiografia para elucidar os fenômenos relacionados à questão social no Brasil corresponde uma difusão respectiva da memória sobre o período

\footnotetext{
${ }^{36}$ José Eduardo Campos de Oliveira Faria, em aula inaugural do programa de mestrado em direito e desenvolvimento da EDESP-FGV, trata especificamente da importância dos anos 1930 como o marco inicial dos problemas relativos ao desenvolvimento, nos quais se contêm as questões relativas à produção da proteção social. "Na América Latina, particularmente, a questão do desenvolvimento cresce de importância a partir da crise da década de 1930, quando o problema da apropriação, concentração e centralização dos excedentes econômicos converte-se no nó górdio do sistema de interdependência mundial. Até o início dessa década, as funções e atribuições do setor público permaneceram mais ou menos semelhantes ao que eram no começo do século. Isso mudou após o colapso dos mercados financeiros em 1929 e o devastador impacto causado pela quebra da bolsa de Nova York. Na América Latina, a crise da década de 1930 é uma espécie de divisor de águas na questão do desenvolvimento, pois, a partir daí, é que se começa a discutir a necessidade de um "empurrão", por meio de intervenção do poder público e investimentos privados estrangeiros, para romper o círculo vicioso entre pobreza e atraso que travava o crescimento econômico dos países da região. (...) Toda essa discussão em matéria de direito e desenvolvimento tem, a meu ver, um denominador comum histórico. Refiro-me à Revolução de 1930, um movimento nacionalista, do ponto cultural; industrializante, no campo econômico; e autoritária no âmbito político. Quando olhamos para a Revolução de 1930 pelo ângulo econômico, logo de saída constatamos dois pontos dignos de nota. O primeiro é representado pelas missões americanas que vieram ao Brasil, principalmente a de 1942, a 'Missão Cook', que recomendou ao regime Vargas a opção por um modelo de industrialização que aproveitasse melhor e mais racionalmente as vantagens comparativas brasileiras, como recursos naturais abundantes e mão-de-obra barata. $\mathrm{O}$ segundo ponto diz respeito aos debates doutrinários e ideológicos suscitados a partir de então sobre a presença do Estado na economia. Tenho em mente dois grandes debates. Por um lado, a conhecida polêmica travada no âmbito do Conselho Federal de Comércio Exterior, em 1944 e 1945, entre Eugênio Gudin e Roberto Simonsen - ou seja, um liberal que defendia a economia de mercado e um empresário que reivindicava maior presença do Estado, por meio de incentivos fiscais, medidas protecionistas e intervenção direta no setor de infra-estrutura. O segundo debate, que talvez seja menos conhecido, foi travado no mesmo período entre Waldemar Martins Ferreira, professor de direito mercantil, banqueiro e político altamente conservador, e Francisco José de Oliveira Vianna, um dos assessores e ideólogos de Getúlio, a respeito do papel e do alcance do direito do trabalho em um contexto de industrialização acelerada propiciada por estratégias de substituição de importações". (Papel do direito na construção do desenvolvimento. Cadernos Direito GV, São Paulo, v. 5, n. 6, pp. 15 e 23, nov 2008).
} 
ora estudado nas obras técnico-jurídicas, destinadas ao treinamento dos profissionais do direito a respeito da legislação e da dogmática trabalhista? Em suma, o que os livros de direito do trabalho dizem quando buscam contar a história desse ramo jurídico?

Os manuais e obras dogmáticas contemporâneas à Era Vargas são praticamente unânimes na reprodução do mito da outorga, com capítulos inteiros dedicados a difundir a ideologia por meio de um discurso laudatório a Getúlio Vargas, à Revolução de 1930 e à obra magnífica representada pela legislação social concedida ao povo brasileiro. Frequentemente o ramo jurídico relacionado à legislação de proteção trabalhista e previdenciária era referido como "novo direito" na Revista do Trabalho, principal periódico jurídico especializado na matéria, que passou a circular a partir de 1933.

Em 1940, o Ministério do Trabalho, Indústria e Comércio lançou um livro contendo um ementário da legislação social expedida desde 1930, intitulado Dez Anos de Legislação Social. A compilação de leis e regulamentos é precedida da transcrição de um discurso do Ministro Waldemar Falcão ${ }^{37}$ na Esplanada do Castelo "saudando o Presidente Getúlio Vargas, em nome da massa trabalhadora, no dia 9 de novembro de 1940”. O discurso repete o elemento crítico aos governos da República Velha, supostamente insensíveis e ineptos no trato da questão social:

\footnotetext{
"Não era possível fugir à realidade das questões pela porta escusa do negativismo.

A questão social aí estava a desafiar a habilidade dos estadistas, e era embalde que se procurava disfarçá-la como um pequenino problema de repressão policial.

Cerca de dez anos já haviam decorrido da adesão do Brasil ao Bureau Internacional do Trabalho, com sede em Genebra, e nenhum resultado prático apreciavel se havia colhido desse fato, em prol dos trabalhadores brasileiros.

Trinta e uma convenções já havia votado então a Assembléia de Genebra e, mau grado, a obrigação de serem enviados, no prazo máximo de um ano, os projetos de convenções votados pela Conferência Internacional do Trabalho à autoridade nacional incumbida da ratificação dos tratados, sucedia estranhamente que apenas seis dessas convenções haviam chegado ao Congresso Nacional de nosso país, muito embora delas fosse partícipe o Brasil.

E dessas seis convenções, nem uma só havia tido ainda andamento em nosso parlamento!

Não era possível encontrar sintoma que fosse mais flagrante, do desapreço pelos direitos das massas trabalhadoras.
}

\footnotetext{
${ }^{37}$ Waldemar Cromwell do Rego Falcão ocupou a pasta do Trabalho, Indústria e Comércio de 1937 a 1941. Foi deputado constituinte em 1933/1934, ligado ao movimento da Liga Eleitoral Católica. Sua vinculação com assuntos trabalhistas vinha de sua experiência política e parlamentar, que também mostrava sua forte vinculação com as orientações da Igreja Católica. Cf. GOMES, Angela de Castro. A invenção do trabalhismo. $3^{\text {a }}$ ed. Rio de Janeiro: Editora FGV, 2005, p. 184.
} 
Era insensato admitir que o Brasil pudesse marchar para diante esmagando as aspirações dos humildes, como se a grandeza das nações lograsse jamais alicerçar-se na injustiça que revolta e no desprezo pelas reivindicações mais legítimas e procedentes. ${ }^{38,}$

Adaucto Fernandes, jurista de obras sobre vários ramos dogmáticos nos anos 1930, dedica o seu Direito Industrial Brasileiro ${ }^{39}$

\begin{abstract}
"ao Exmo. Sr. Dr. Getúlio Vargas, D. D. Presidente da República, e, expressão suprema de socialismo sul-americano, a quem o Brasil deve a creação e a organização do Direito Industrial, - útlima conquista socioéthico-juridica do operariado moderno à face do Estado Novo. Homenagem de A. Fernandes."
\end{abstract}

E ao comentar as atribuições do Departamento Nacional do Trabalho afirma que

“[É] esse o órgão supremo, directa e immediatamente entrosado na complexa organisação geral do Ministério do Trabalho, Industria e Commercio, com séde na Capital da Republica e Jurisdição forçada em todo territorio nacional.

Neste particular, até antes da Revolução de Outubro de 1930, nada tínhamos sobre o Direito Industrial digno de nota e estudo." 40

Hirosê Pimpão, advogado pioneiro, com a experiência de presidente de Junta de Conciliação de Julgamento, foi também doutrinador com diversas obras sobre o "novo direito" no Rio de Janeiro. Em seus comentários à Lei n. 62, de 5 de junho de 1935 (conhecida como lei de despedida ou lei da despedida injusta à época), dedicou a obra ao "Doutor Getúlio Vargas, de cujas soberbas realizações resultou o moderno Direito Social Trabalhista Brasileiro"41. No ano seguinte, em 1942, Pimpão dedicou todo o livro intitulado Getúlio Vargas e o Direito Social Trabalhista à "divulgação de um dos aspectos da obra imperecivel realizada pelo sr. Getúlio Vargas, à frente do nosso Governo" 42 . Ao falar do nascimento do "novo direito", repetiu a crítica da insuficiência da conduta dos governos da Primeira República:

\footnotetext{
${ }^{38}$ BRASIl. MTIC. Dez anos de legislação social: ementário dos atos oficiais expedidos de 1930 a 1940 . Rio de Janeiro: Imprensa Nacional, 1940, pp. V e IX.

${ }^{39}$ FERNANDES, Adaucto. Direito industrial brasileiro. Rio de Janeiro: Editor A. Coelho Branco Filho, 1937 , p. 3.

${ }^{40}$ FERNANDES, Adaucto. Direito industrial brasileiro. Rio de Janeiro: Editor A. Coelho Branco Filho, 1937, p. 81.

${ }^{41}$ PIMPÃO, Hirosê. Despedida injusta: a lei n. 62 na teoria e na prática (comentários e jurisprudência). Curitiba: Editora Guaíra. 1941, p. 7.

${ }^{42}$ PIMPÃO, Hirosê. Getúlio Vargas e o direito social trabalhista. Rio de Janeiro: Gráfica Guarany, 1942, p. 7.
} 


\begin{abstract}
"Assim é que podemos concluir: - embora as tentativas fossem muitas e embora alguma coisa se tenha conseguido no campo do direito social trabalhista na primeira fase republicana, o que é verdade é que, as poucas leis que conseguiram impor-se ao nosso meio industrial primário, não foram suficientes de, por si sós, justificar o esgalhamento de um novo rebento da secular árvore do Direito, formando uma nova disciplina jurídica, o que só foi possível depois da revolução redentora de outubro de 1930 e graças ao vulto predestinado para a realização das profundas transformações sociais por que o Brasil devia passar, graças ao eminente Presidente Getúlio Vargas, o verdadeiro criador do Direito Social Trabalhista Brasileiro." ${ }^{33}$
\end{abstract}

Cesarino Júnior inicia o capítulo X de seu Direito Social Brasileiro dando notícia da legislação anterior, mas chamando-a de "capitalista", em contraposição ao caráter "social" da legislação pós-1930:

\begin{abstract}
“A Legislação Social no Brasil começou decididamente após a revolução de 1930. O Govêrno Provisório, então constituído, sob a chefia do atual Presidente da República, Dr. Getulio Vargas, criou o Ministério do Trabalho, Indústria e Comércio, que principiou realmente a elaboração de nossas leis sociais.

Isto não significa que antes, mesmo no tempo do Império, não tivéssemos leis sobre o trabalho. Mas, não era ainda a 'legislação social', mas sim apenas disposições legislativas fragmentárias e animadas ainda do espírito que tratadistas com Paul Pic, chama de capitalista." ${ }^{44}$
\end{abstract}

Cesarino prossegue analisando dispositivos das constituições brasileiras de 1934 e 1937 e cita as contribuições doutrinárias de outros pioneiros, como Waldyr Niemeyer, Araújo Castro e Helvécio Xavier Lopes, este último um dos editores da Revista do Trabalho, ao lado de Dorval Lacerda, que viria a ser nomeado Procurador da Justiça do Trabalho, sendo indicado ainda para integrar a comissão responsável pela elaboração da Consolidação das Leis do Trabalho posteriormente. Mas ao discorrer sobre a casuística do "novo direito" afirmou que "[A] jurisprudência, sobretudo administrativa, é copiosa, mas não se pode dizer que tenha uma atuação de relevo na elaboração do novo direito" 45 .

Ainda no Estado Novo, Orlando Gomes era a nota fora do tom entre os juristas. $\mathrm{Na}$ "síntese histórica” empreendida no capítulo XI ("A relação de trabalho na legislação

\footnotetext{
${ }^{43}$ PIMPÃO, Hirosê. Getúlio Vargas e o direito social trabalhista. Rio de Janeiro: Gráfica Guarany, 1942, p. 51.

${ }^{44}$ CESARINO JÚNIOR, Antonio Ferreira Cesarino. Direito social brasileiro. São Paulo: Livraria Martins Editora, 1943, p. 121.

${ }^{45}$ CESARINO JÚNIOR, Antonio Ferreira Cesarino. Direito social brasileiro. São Paulo: Livraria Martins Editora, 1943,. p. 124.
} 
brasileira") de sua Introdução ao Direito do Trabalho, o autor expõe aguda crítica à legislação da década de 1930:

\begin{abstract}
"A legislação do trabalho no Brasil nascera e crescera sob o signo da improvisação.

Elaborada por atacado, quase de um jacto, que inundou o país com decretos de inspiração exótica, avolumou-se tanto em tão pouco tempo, que seu conhecimento se tornou penoso até mesmo aos especialistas. Legislou-se a granel, sem calma, sem ordem, sem segurança, imprimindo-se às leis trabalhistas um sentido analítico, que lhes deu o caráter de regulamentos, com abundância de dispositivos casuísticos. Insatisfeito, o Executivo comprazia-se na expedição de regulamentos e portarias, que engrossaram a maré montante das normas de proteção ao trabalhador.

Mais grave ainda do que a pletora era a inconstância. Ditadas, não raro, de afogadilho, ressentiam-se as leis de imperfeições, quando se não revelavam inadaptáveis, de todo em todo. $\mathrm{O}$ espírito pragmático do legislador aconselhava-lhe a atitude reformista, a fim de que os defeitos fôssem corrigidos. Conquanto louvável o propósito, sua realização contribuía para aumentar a confusão da babel legislativa. Novas leis, freqüentemente, suprimiam artigos, emendavam textos, introduziam parágrafos, alteravam alíneas e eliminavam palavras, modificando, derrogando, inovando. Não raro, era tôda a lei que se substituía, por mudança na orientação política do país. A disciplina do fato sindical constitui o mais frisante exemplo dessa irriquietude. Em menos de 10 anos, três leis foram postas em vigor: os decs. ns. 19.776 e 24.694 e o dec.-lei n. 1.402, respectivamente de 1931, 1934 e 1940, cada qual obediente a diversa concepção política.

Para remediar males tão graves, de perniciosas conseqüências, sobretudo em legislação destinada a homens de instrução deficiente, era imperioso que se empreendesse a relevante tarefa de condensação de tantas regras esparsas e várias.

Fio o que afinal se fêz. As leis trabalhistas do país estão consolidadas."
\end{abstract}

Em 1944 a Revista do Conselho Nacional do Trabalho traz textos elogiosos à gestão de Alexandre Marcondes Filho à frente do Ministério do Trabalho, Indústria e Comércio, que completava dois anos, e mantinha-se “inescedível na continuação da meritória obra que vem sendo realizada" ${ }^{\circ}$.

Jarbas Peixoto, doutrinador e também Procurador da Justiça do Trabalho, no capítulo sobre a "evolução do direito do trabalho brasileiro" de seus comentários à Consolidação, defende que a violência presente no tratamento da questão social no pré1930 se devia à ausência de uma legislação própria, negando que o advento desta tenha

\footnotetext{
${ }^{46}$ GOMES, Orlando. Introdução ao direito do trabalho. Rio de Janeiro: Forense, 1944, pp. 195-6.

47 BEZERRA, Celso de. O trabalhador e o estado nacional. Revista do Conselho Nacional do Trabalho. Rio de Janeiro, n. 18, p. 89, jan-fev 1944.
} 
tido o condão de "produzir" uma questão social até então inexistente e rebatendo interpretação corrente à época:

\begin{abstract}
"Se o problema do trabalho não apresentava, com efeito, no Brasil, o aspecto de asfixia tão premente noutros povos, não é também menos verdade que só o fato dessa ausência de disciplina jurídica especial estimulava o apêlo aos recursos de pura violência.

(...)

A criação de um Ministério especializado do trabalho, englobando os dois outros elementos fundamentais da produção, a indústria e o comércio, longe de ter vindo instituir fatores de agitação e de desordem, como não falta ainda hoje quem afirme, revestiu-se precisamente do caráter de um desafôgo inadiável.

(...)

Admitir que a criação do Ministério do Trabalho, por si só, e a elaboração legislativa que lhe foi a conseqüência imediata, tenham podido produzir uma 'questão social' inexistente, seria presumir, por ilogismo, que só então tivessem aparecido os 600.000 trabalhadores da indústria e os 800.000 trabalhadores do comércio naquela data constatados no país. É franciscana a pobreza do argumento. Preexistia assim, ao Ministério e à legislação revolucionária do trabalho, a 'questão social' que a maioria só enxerga quando atinge os distúrbios de praça pública, às greves gerais espetaculares, às repressões extremas e cruentas."
\end{abstract}

Mas se o panorama da produção de conhecimento jurídico contemporâneo ao período estudado mostra um certo adesismo, revelador da penetração no imaginário dos profissionais do direito da ideologia da outorga, com raras exceções, o que se pode dizer dos manuais de direito do trabalho dos dias de hoje? Afinal, trata-se de materiais de referência, lidos em profusão por operadores do direito que, em sua maioria, contêm digressões introdutórias de cunho histórico, que buscam resgatar as origens e o desenvolvimento do ramo trabalhista ao longo do tempo. Considerando que se trata, em muitos casos, da única leitura sobre a história do direito do trabalho a que muitos profissionais do direito terão acesso, é relevante buscar entender se a historiografia trabalhista tem algum eco sobre os juslaboralistas.

Antes de passar à análise dos manuais, cumpre efetuar os mesmos testes propostos em relação à talvez única obra direcionada à história do direito do trabalho escrita exclusivamente por operadores do direito de que se tem notícia. Trata-se do livro História do Direito do Trabalho no Brasil, composto de três artigos que buscam resumir a história do trabalho em geral, do direito do trabalho no Brasil e da Justiça do Trabalho no Brasil, respectivamente. Interessam aos fins do presente trabalho os dois últimos artigos.

${ }^{48}$ PEIXOTO, Jarbas. Código do trabalho: interpretação e prática da Consolidação das Leis do Trabalho. Rio de Janeiro: Editora Nacional de Direito, 1945, pp. 81-2. v. 1. 
Ao comentar a história do direito coletivo no Brasil, Amauri Mascaro Nascimento $^{49}$ recorre ao método da enumeração legislativa, mas cita uma obra propriamente historiográfica para lastrear alguns dados, qual seja, o livro de Aziz Simão ${ }^{50}$ intitulado Sindicato e Estado, um dos mais representativos do grupo de trabalhos pré1970, que tinham por foco a legislação sindical e concluíam pelo enfraquecimento dos trabalhadores em virtude de seu atrelamento ao Estado. O relato do autor sobre a política sindical varguista revela a influência dessa interpretação ${ }^{51}$.

Ives Gandra Martins Filho, em artigo sobre a história do direito do trabalho, também recorre à análise legislativa, concluindo, por exemplo, que "[A] atuação das comissões [Mistas de Conciliação, instituídas por meio do Decreto n. 21.396, de 12 de maio de 1932, destinadas a conciliar conflitos coletivos] foi irrelevante no Brasil, por seu caráter não impositivo das soluções" ${ }^{~}$, , assumindo uma congruência entre lei e realidade. Não há citação de obras propriamente historiográficas e nem informações sobre a consulta a fontes da época no artigo.

Partindo para o universo dos manuais de direito do trabalho, passa-se a uma análise do Curso de Direito do Trabalho, de Maurício Godinho Delgado. Ao tratar do que chama do que denomina "modelo de ordem jurídica trabalhista autoritário", o autor reforça a existência de uma característica típica de antecipação de soluções aos conflitos nesse modelo:

"Os problemas propostos pelas duas vertentes democráticas anteriores
["normatização autônoma e privatística" e "normatização privatística
subordinada"] não se colocam ao padrão subordinado estatal: a minuciosa
legislação estatal institui formas e conteúdos de solução de conflitos,
procurando se antecipar (ou sufocar), através de uma cuidadosa
operosidade legislativa, às alternativas jurídicas que se poderiam,
privadamente estabelecer. Nesse padrão jurídico, a elaboração estatal do
Direito do Trabalho consubstancia um processo de restringida
participação da sociedade civil e cria uma dinâmica cujas linhas mestras

${ }^{49}$ NASCIMENTO, Amauri Mascaro. História do direito do trabalho no Brasil. In: FERRARI, Irani; NASCIMENTO, Amauri Mascaro e MARTINS FILHO, Ives Gandra da Silva. História do trabalho, do direito do trabalho e da justiça do trabalho. São Paulo: LTr, 1998, p. 77.

${ }^{50}$ SIMÃO, Aziz, Sindicato e Estado. São Paulo: Dominus, 1966.

${ }^{51}$ NASCIMENTO, Amauri Mascaro. História do direito do trabalho no Brasil. In: FERRARI, Irani; NASCIMENTO, Amauri Mascaro e MARTINS FILHO, Ives Gandra da Silva. História do trabalho, do direito do trabalho e da justiça do trabalho. São Paulo: LTr, 1998, pp. 83-95.

${ }^{52}$ Samuel Fernando de Souza refuta a tese da inoperância das Comissões Mistas de Conciliação em sua tese de doutorado (Coagidos ou subornados: trabalhadores, sindicatos, Estado e leis do trabalho nos anos 1930. 2007. 228 f. Dissertação de Doutorado - Instituto de Filosofia e Ciências Humanas, Universidade de Campinas, 2007, pp. 12-21. Disponível em: < http:// cutter. unicamp.br /document/ ?code $=$ vtls000436523 $>$. Acesso em: 16 novembro 2011, pp. 177-90). O autor relatou um "funcionamento surpreendente" das Comissões e analisou processos da $1^{\mathrm{a}}$ Comissão Mista de Conciliação do Distrito Federal. 
se caracterizam por assegurarem o contínuo impedimento a essa participação.

O exemplo clássico plenamente configurado do modelo de normatização estatal subordinada consiste naquele constituído pelas experiências fascistas que caracterizaram particularmente a Itália e a Alemanha, na primeira metade do século $\mathrm{XX}$, tendo influência em inúmeros outros contextos nacionais (Portugal, Espanha e, inclusive, o Brasil)., ${ }^{, 53}$

Embora não se trate propriamente de tópico destinado a expor a história do juslaboralismo, observa-se que a descrição do modelo proposta pelo autor também assume a congruência entre lei e realidade, e não contempla as análises historiográficas que mostram níveis de participação relevantes dos trabalhadores na solução dos conflitos trabalhistas, por meio do uso da própria legislação "antecipada", que ganha relativa independência a partir dos usos que a consciência legal dos trabalhadores direciona para os órgãos de proteção, ainda que diversas limitações e dificuldades sejam constatadas.

Amauri Mascaro Nascimento relata, em seu Curso de Direito do Trabalho ${ }^{54}$, as greves da Primeira República, a atuação dos anarquistas e destaca de forma interessante o que chama de doutrina jurídica reivindicatória, capitaneada pelo advogado e militante socialista Evaristo de Moraes, que integraria no pós-1930 a equipe do Ministério do Trabalho, Indústria e Comércio como o seu primeiro consultor. Evaristo frequentemente publicava artigos na imprensa pedindo medidas de proteção social e denunciando as condições de trabalho nas indústrias, tendo reunido alguns deles no livro Apontamentos de Direito Operário, em 1905. Menciona que a expansão do direito do trabalho a partir de 1930 veio também como consequência das conquistas angariadas nas duas décadas anteriores. No mais, segue na mesma linha do artigo de sua autoria antes analisado.

Francisco Antonio de Oliveira, à sua vez, dedica quase toda a digressão histórica à análise das disposições sobre proteção a direitos sociais presentes nas constituições brasileiras, mencionando ainda a "origem administrativa" da Justiça do Trabalho ${ }^{55}$.

O manual denominado Introdução ao Direito do Trabalho, de Evaristo de Moraes Filho e Antonio Carlos Flores de Moraes, contém um relato do período correspondente às três primeiras décadas do século $\mathrm{XX}$, que revela maior conhecimento sobre personagens relevantes nas lutas da Primeira República (incluindo seu pai Evaristo de Moraes) e destaca a "cristalização do novo direito [por meio dos] despachos do ministro

\footnotetext{
${ }^{53}$ DELGADO, Mauricio Godinho. Curso de direito do trabalho. $5^{\text {a }}$ ed. São Paulo: LTr, 2006, p. 102.

${ }^{54}$ NASCIMENTO, Amauri Mascaro. Curso de direito do trabalho. $27^{\mathrm{a}}$ ed. São Paulo: Saraiva, 2012, pp. 98-9 e 103.

${ }^{55}$ OLIVEIRA, Francisco Antonio de. Curso de direito do trabalho. São Paulo: LTr, 2011, pp. 64-77 e 131.
} 
de Estado, os pareceres do consultor jurídico e as decisões das Juntas, das Comissões Mistas e das autoridades administrativas do próprio Ministério"56.

${ }^{56}$ MORAES FILHO, Evaristo de, MORAES, Antonio Carlos Flores de. Introdução ao direito do trabalho. $10^{\mathrm{a}}$ ed. São Paulo: LTr, 2010, pp. 109-10. Em outras obras, principalmente em seu O problema do sindicato único ( $2^{\mathrm{a}}$ ed. São Paulo: Editora Alfa-omega, 1978) único, o autor denuncia a parcialidade da propaganda varguista que coloca 1930 como o marco da invenção da proteção social no Brasil. 


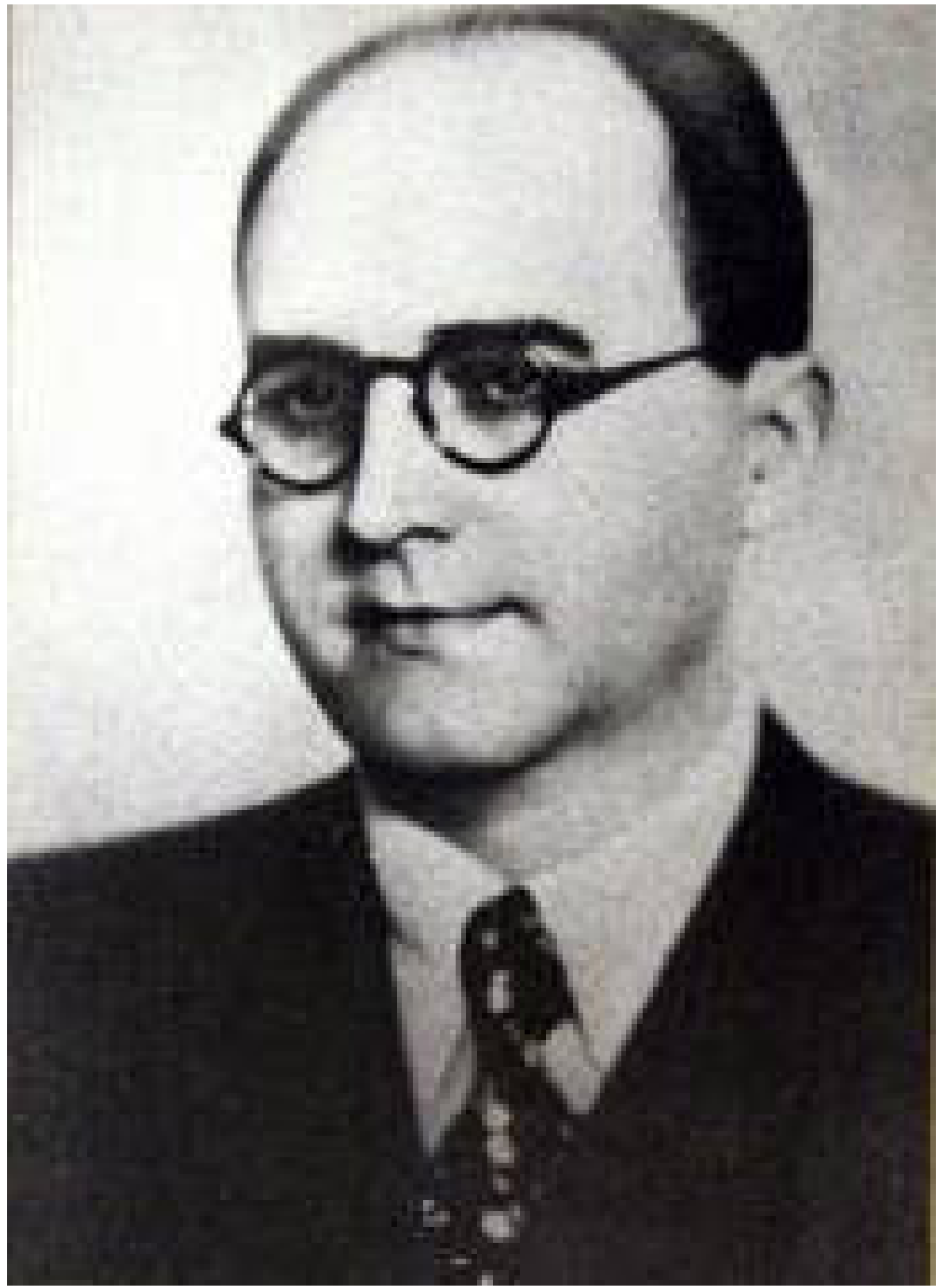

Fotografia 2 - Ministro Waldemar Falcão

Fonte: $\quad<$ http://www1.previdencia.gov.br/85anos/pages/04-WALDEMAR\%20FAL \%C7\%C3O\%2025111937-13061941.htm> 


\section{O DESENHO JURÍDICO-INSTITUCIONAL DO CONSELHO NACIONAL DO TRABALHO E SUA INSERÇÃO NA POLÍTICA VARGUISTA}

O presente trabalho tem por foco a atividade judicante, de solução de conflitos em matéria trabalhista, do Conselho Nacional do Trabalho no período que antecede a implantação da Justiça do Trabalho no âmbito do Poder Judiciário no Brasil.

Trata-se do período iniciado com a criação do CNT, em 1923, e que finda com a sua extinção em 1946, quando o órgão dá lugar ao Tribunal Superior do Trabalho. A transformação do CNT em órgão propriamente judicante em matéria de direitos trabalhistas e previdenciários deu-se em 1934, após a reforma do Conselho.

No início do século XX observa-se uma paulatina criação de regras estatais visando a regular as relações de trabalho ${ }^{57}$. Paralelamente a esse esforço de criação legislativa houve algumas tentativas de se estabelecer órgãos que fossem responsáveis pela aplicação e pela interpretação dessas regras. No entanto, apenas em 30 de abril de 1923 seria criado o Conselho Nacional do Trabalho, por meio do Decreto $\mathrm{n}^{\mathrm{o}} 16.027$, com atribuição consultiva voltada à própria administração pública “em assuntos referentes à organização do trabalho e da previdência social" (artigo $1^{\circ}$ ), devendo também ocupar-se dos "sistemas de conciliação e arbitragem" (artigo $2^{\circ}$ ). Foi ainda concebido como instância recursal em matéria de seguridade social e órgão administrativo responsável por autorizar a demissão de servidores públicos estáveis.

O CNT, dessa forma, constituiu-se como órgão consultivo e administrativo, tanto em matéria trabalhista quanto previdenciária, mas também lhe cabia atuar como órgão julgador ou deliberativo. As disposições do Decreto n. 18.074, de 1928, evidenciam sua função consultiva, colocando-o como uma "corporação destinada ao estudo dos problemas da economia social e de todos os assuntos que possam interessar à organização do trabalho e da previdência social" (artigo $1^{\circ}$ ), encarregada de "responder consultas dos Poderes Executivo e Legislativo da União" (artigo 10, p. $1^{\circ}$ ) e de propor ao governo as medidas que julgasse "convenientes no tocante à previdência social e à normalização do trabalho" (artigo 10, p. $3^{\circ}$ ).

\footnotetext{
${ }^{57}$ A cronologia e a descrição geral da legislação criada à época trazida no presente tópico consta de BRASIL. Tribunal Superior do Trabalho. Fundo Conselho Nacional do Trabalho. Descrição. Disponível em: <www3. tst.jus.br/ Srcar/ Documentos/ CNT_ Descricao_ Internet.pdf $>$, acesso em 18 maio 2011. V. também BRASIL. Tribunal Superior do Trabāho. CGEDM. Organograma Evolutivo do Conselho Nacional do Trabalho. (documento interno não publicado, disponível sob demanda)
} 
Sua função administrativa principal era fiscalizadora, e está expressa no citado artigo 10, do Decreto $18.074 / 1928$, sobretudo nos parágrafos $4^{\circ}, 5^{\circ}$ e $6^{\circ}$. Neles está posto que também eram atribuições do CNT:

\footnotetext{
"cumprir e fazer cumprir as disposições legais e regulamentares referentes às caixas de aposentadoria e pensões dos ferroviários, dos portuários e de outras classes que vierem a ser compreendidas no regime da lei n..$^{\circ}$ 5.109, de 20 de dezembro de 1926";

"fiscalizar as companhias e empresas que operarem sobre seguros contra acidentes do trabalho e quaisquer outros seguros sociais, mediante instruções baixadas pelo Ministro da Agricultura, Industria e Comercio"; e,

"fiscalizar a execução do regulamento para a concessão de férias aos empregados e operários dos estabelecimentos comerciais, industriais, bancários e outros".
}

A função arbitral ou deliberativa do CNT aparece regulada no p. $8^{\circ}$ do artigo $10^{\circ}$ do Decreto n. 18.074/1928, cabendo ao órgão:

\begin{abstract}
"intervir, quando solicitado por uma ou ambas as partes, nas questões coletivas entre operários e patrões, podendo servir de mediador para acordo ou arbitragem, desde que os interessados se obriguem previamente a aceitar o acordo ou a cumprir a decisão arbitral".
\end{abstract}

Até a criação do Ministério do Trabalho, Indústria e Comércio, por meio do Decreto n. 19.433, de 26 de novembro de 1931, o Conselho Nacional do Trabalho integrava o Ministério da Agricultura, Indústria e Comércio. Logo após, com o Decreto n. 20.886, de 30 de dezembro de 1931, deu-se novo quadro de pessoal administrativo, técnico e fiscal ao CNT.

Por meio do Decreto n. 22.132, de 25 de novembro de 1932, o Conselho Nacional do Trabalho passou a ter a competência para resolver conflitos em matéria trabalhista, investido de poderes para impor suas decisões aos litigantes. Abriam o decreto os seguintes dizeres:

"O Chefe do Govêrno Provisorio da República dos Estados Unidos do Brasil, na conformidade do art $1^{\circ}$, do decreto n. 19.398 de 11 de novembro de 1930, resolve instituir Juntas de Conciliação e Julgamento, para dirimirem os litigios oriundos de questões de trabalho em que sejam partes empregados sindicalizados e que não afetem as coletividades a que pertencerem os litigantes, e subordinar as suas funções ás disposições seguintes." 
A ressalva trazida na expressão "que não afetem as coletividades a que pertencerem os litigantes" se refere às Comissões Mistas de Conciliação, destinadas à conciliação de dissídios de ordem coletiva. O artigo 14, do Decreto n. 21.396, de 12 de maio de 1932, dispunha que à conciliação frustrada se seguiria uma "recomendação" da CMC para a submissão do dissídio a arbitragem ("Verificada a impossibilidade de conciliação, do que igualmente se lavrará acta, por todos assignada, o presidente da Commissão proporá ás partes submetter o litigio a juizo arbitral").

O Decreto n. 22.884, de 04 de julho de 1933, não alterou a organização estabelecida para o Conselho, mas apenas retirou de seu campo competencial a fiscalização do cumprimento das obrigações previstas no Decreto de Nacionalização do Trabalho (Decreto n. 20.291, de 12 de agosto de 1931). Dessa forma, caberia ao Departamento Nacional do Trabalho (e não mais ao Serviço de Fiscalização do CNT) a fiscalização do cumprimento por parte das empresas da exigência de contratação de dois terços de trabalhadores brasileiros natos. O Serviço de Fiscalização do CNT foi formalmente extinto na oportunidade.

Todavia, a intensificação da atividade propriamente judicante do CNT se inicia apenas com o advento do Decreto n. 24.784 , de 14 de julho de $1934^{58}$. Eis o marco inicial do período que interessa diretamente ao presente trabalho. Pelo artigo $4^{\circ}$ do citado decreto, o CNT deveria funcionar como tribunal de embargos, por meio de seu Pleno, e como órgão julgador ou deliberativo de primeira instância, por meio de suas Primeira, Segunda e Terceira Câmaras, reorganizadas e distribuídas em 1939 (Decreto n. 1.346, de 15 de junho

\footnotetext{
${ }^{58}$ Há trabalhos historiográficos que abordam a relação entre Estado, trabalhadores (individualmente ou representados por sindicatos) e patrões, por meio da análise de processos do CNT, já nos anos 1920. Trata-se de trabalhos que admitem que o CNT, mesmo com atribuições oficiais meramente consultivas (Decreto $\mathrm{n}$. 16.027, de 30 de abril de 1923) ou de promoção de estudos (Decreto n. 18.074, de 19 de abril de 1928), exerceu papel expressivo na constituição dos direitos de índole trabalhista, chegando a falar em “judicialização do trabalho" para denominar a submissão de conflitos diversos ao CNT. Cf., a propósito, SOUZA, Samuel Fernando de. Coagidos ou subornados: trabalhadores, sindicatos, Estado e leis do trabalho nos anos 1930. Dissertação de Doutorado - Instituto de Filosofia e Ciências Humanas, Universidade de Campinas, 2007. Disponível em: <http:// cutter. unicamp.br /document/ ?code = vtls000436523>. Acesso em: 16 nov 2011. Contudo, é preciso ressaltar que tais trabalhos (e especialmente o citado) têm por escopo específico verificar a afirmação de direitos trabalhistas, ainda que de forma incipiente e sem a garantia da coerção estatal, no período anterior a 1930. No trabalho citado, o autor verifica nos processos do CNT o nascimento entre os trabalhadores de uma cultura de solidariedade bem como de uma matriz discursiva que incorporava a filosofia jurídica oficial e a lógica paternalista do Estado protetor à sua cultura, dentre outras "vitórias" válidas e legítimas da classe operária à época, mesmo que não diretamente advindas de decisões jurídicas estatais oficiais e coercitivas. Por isso, creio ser imprópria a referência a "judicialização", por maior amplitude que se dê à expressão. Penso que as discussões e movimentações verificadas nos processos do CNT nos anos 1920 sejam mais um elemento do novo espectro político próprio das relações de trabalho surgidas à época, com limitada eficácia no âmbito propriamente jurídico.
} 
de 1939) segundo uma Câmara de Previdência Social e uma Câmara de Justiça do Trabalho. Estas atribuições eram até então inéditas no desenho institucional do CNT, e foram introduzidas para conferir-lhe definitivamente competências para dirimir conflitos em matéria trabalhista.

A organização do CNT, a partir de 1934, passou a ser a seguinte:

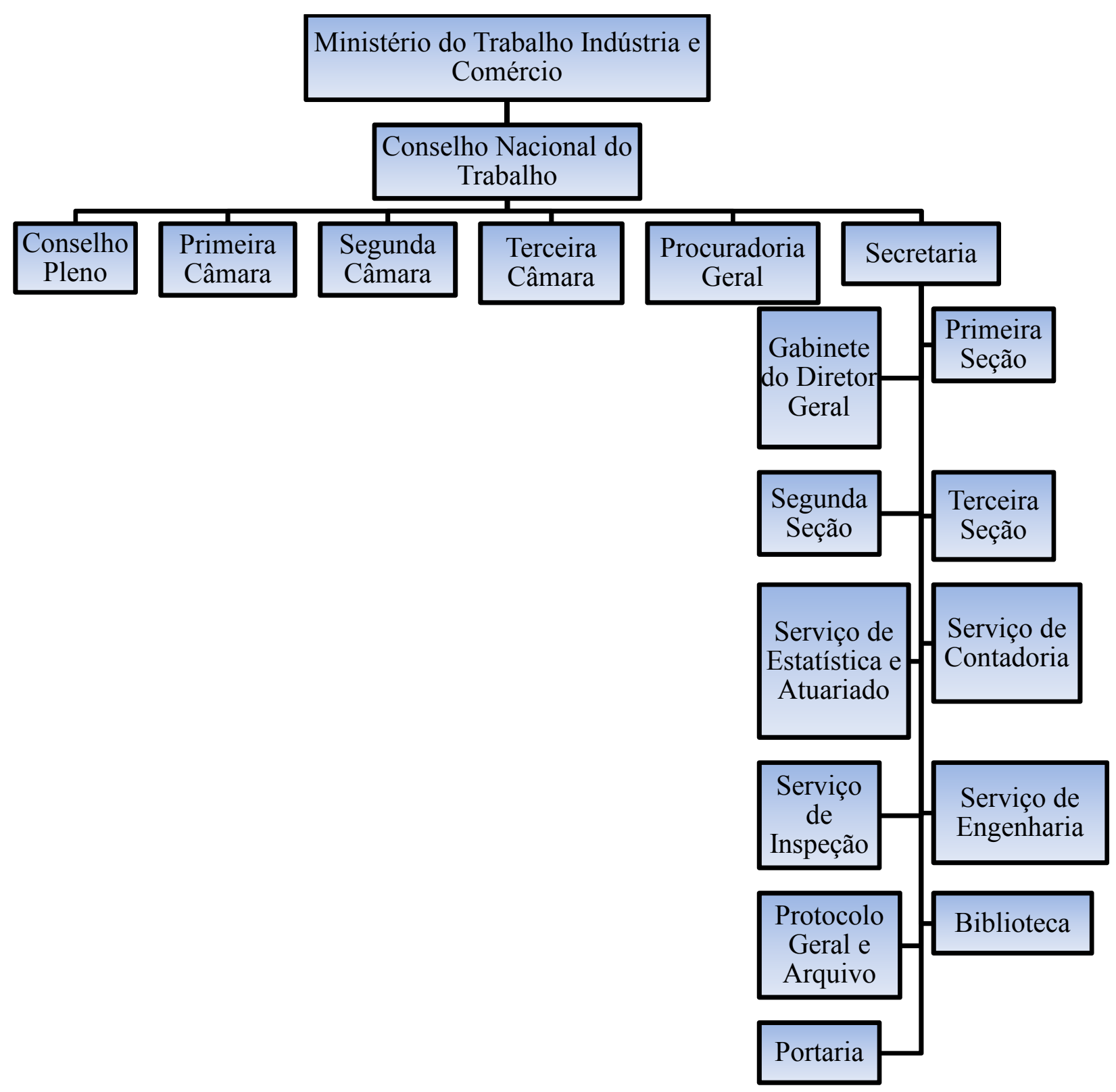

Gráfico 1 - Organização do CNT conforme disposto no Decreto n. 24.784, de 14 de julho de 1934 
O Conselho Pleno, composto por dezoito membros, acumulava competências consultivas, atos de gestão administrativa do órgão e atuava ainda como tribunal de embargos. As consultas sobre "economia, organização do trabalho e previdência social" (artigo 12, parágrafo $1^{\mathrm{o}}$, inciso I) poderiam ser formuladas pelo próprio Ministério. $\mathrm{O}$ "Governo" poderia "sugerir e propor (...) as medidas que julgar convenientes no tocante à previdência social e à normalização do trabalho" (artigo 12, parágrafo $1^{\circ}$, inciso III).

Podia ainda o Conselho Pleno:

\footnotetext{
"intervir nas Caixas e Institutos de Aposentadoria e Pensões e em quaisquer outras instituições de previdência social que sejam criadas, para normalizar a sua administração, corrigir erros e abusos, fiscalizar as eleições e quaisquer outros atos" (artigo 12 , parágrafo $2^{\circ}$, inciso II).
}

Tinha também a atribuição de "[D]ecidir, funcionando como tribunal arbitral e irrecorrível, os dissídios entre empregados e empregadores, quando houver falhado o recurso legal da conciliação" (artigo 12, parágrafo $3^{\circ}$, inciso I). A função de tribunal de embargos aparece no artigo 12, parágrafo $3^{\circ}$, inciso VIII ("Tomar conhecimento, se couber, dos embargos opostos aos acórdãos das Câmaras e julgá-los”).

As Câmaras, compostas por cinco membros, funcionavam como órgãos julgadores de primeira instância, decidindo as reclamações contra atos das Caixas e Institutos de Aposentadoria e Pensões "e das "empresas e estabelecimentos a umas e outros ligados, no tocante à estabilidade e outras garantias asseguradas por lei aos respectivos empregados" (artigo 13).

O Procurador Geral oficiava no Conselho Pleno e nas Câmaras. Tinha também por atribuição representar a União nas ações de nulidade "de atos e soluções do Conselho" (artigo 16).

A Secretaria, além de "serviços administrativos e técnicos" (artigo 18), tinha por incumbência "sistematizar a legislação relativa à matéria de previdência e economia social" (artigo 19, inciso I). Às seções da Secretaria cabiam os serviços processuais acessórios, tais como recebimento de petições e documentos e sua respectiva autuação.

O rol de conflitos submetidos ao CNT era amplo, não se restringindo somente aos dissídios individuais e coletivos. O Conselho era competente para julgar processos referentes a "reclamações referentes às empresas de serviço público" (artigo 19, parágrafo $2^{\circ}$ ), "reclamações e recursos concernentes a assunto que interesse às Caixas e Institutos de 
Aposentadoria e Pensões", "prestação de assistência médica e hospitalar" (artigo 19, parágrafo $3^{\circ}$ ) e "eleições nas juntas e conselhos administrativos das Caixas e Institutos de Aposentadoria e Pensões" (artigo 19, parágrafo $4^{\circ}$ ).

O crescimento das Caixas e Institutos bem como a extensão dos serviços, prestações e benefícios por elas ofertados fez necessária a criação de um Serviço de Estatística e Atuariado "para o estabelecimento de táboas de mortalidade, quotas de aposentadoria, taxas de salários e elaboração dos demais elementos indispensáveis ao preparo de balanços técnicos das Caixas e Institutos de Aposentadoria e Pensões" bem como para "revisão dos cálculos apresentados pelas Caixas e Institutos para a fixação dos coeficientes dos benefícios de aposentadoria e pensões" (artigo 19, parágrafo $5^{\circ}$ ). Foi constituído até mesmo um Serviço de Engenharia (artigo 19, parágrafo $8^{\circ}$ ), responsável por "[O]rganizar as bases para o concurso de projetos de construção de casas para associados das Caixas (...) e de prédios para suas sedes”.

Havia também uma Contadoria, responsável pela análise das "propostas orçamentárias e pedidos de créditos suplementares das Caixas e Institutos” (artigo 19, parágrafo $6^{\circ}$ ). O extinto Serviço de Fiscalização deu lugar ao Serviço de Inspeção, responsável pela fiscalização das Caixas e Institutos (artigo 19, parágrafo $7^{\circ}$ ).

Das decisões do Conselho Pleno cabia recurso para o Ministro do Trabalho, Indústria e Comércio "quando a deliberação tiver sido adotada pelo voto de desempate" ou “quando, alegando violação da lei aplicável ou modificação da jurisprudência até então observada (...) o recorrente obtiver do Ministro a avocação do respectivo processo". Eis a avocatória, que aparecia regulada no artigo $5^{\circ}$.

Esse desenho da organização do CNT permaneceu até 15 de junho de 1939, quando foi editado o Decreto n. 1.346, para reorganização do Conselho. A Procuradoria Geral passou a oficiar também junto aos Conselhos Regionais do Trabalho, por meio da constituição de Procuradorias Regionais (artigo 14)

As Câmaras foram reduzidas a uma Câmara de Justiça do Trabalho e uma Câmara de Previdência Social, ambas com nove membros cada uma.

O robustecimento da ação sindical começava a criar os primeiros problemas de ordem jurídica. O instituto jurídico da categoria (profissional ou econômica), aliado ao critério geográfico de demarcação da abrangência das entidades sindicais, fez surgir questões sobre a competência de um ou outro Conselho Regional para analisar as pretensões contidas na negociação coletiva que extrapolava os limites provinciais. Para resolver o problema a Câmara de Justiça do Trabalho passou a ser competente para, 
originariamente, "conciliar e julgar os dissídios coletivos que excedam a jurisdição dos Conselhos Regionais (artigo $8^{\circ}$, inciso I, alínea "a") bem como para "[E]stender a toda a categoria, nos termos da lei, os contratos coletivos celebrados por associações sindicais cuja área de ação exceda a jurisdição dos Conselhos Regionais do Trabalho" (artigo 8*, inciso I, alínea “c”).

A técnica das competências originárias foi ainda complementada pela técnica correspondente ao estabelecimento de competências sobre matérias submetidas a juízo de única instância da Câmara de Justiça do Trabalho. Assim, esta seria responsável por "homologar acordos celebrados nos dissídios coletivos que excedam a jurisdição dos Conselhos Regionais", "julgar conflitos de jurisdição entre os Conselhos Regionais" (artigo $8^{\circ}$, inciso II, alínea "b"), mantida a competência recursal de última instância sobre as decisões dos Regionais (artigo $8^{\circ}$, inciso III).

A Câmara de Previdência Social conservou as competências estabelecidas na organização anterior e passou também a "fiscalizar a administração dos Institutos e Caixas de Aposentadoria e Pensões" (artigo 9 ${ }^{\circ}$, inciso I), embora houvesse sido criada uma Inspetoria com tal atribuição (artigo 29).

Os antigos Serviços, ligados à Secretaria, foram distribuídos entre os Departamentos de Justiça do Trabalho e de Previdência Social (artigos 27 e 28).

A organização do CNT, a partir de 1939, passou a ser a seguinte: 


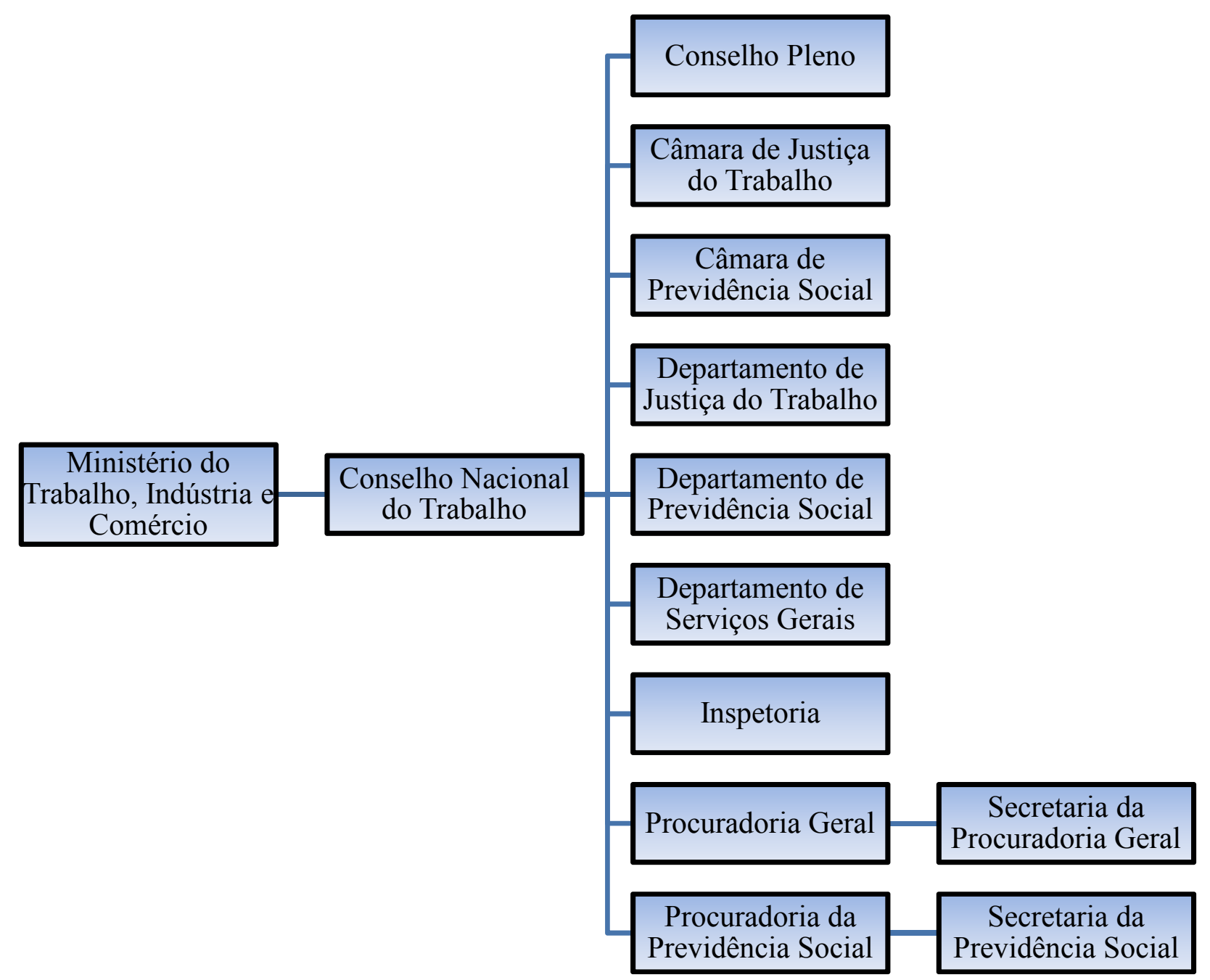

Gráfico 2 - Organização do CNT conforme disposto no Decreto n. 1.346, de 15 de junho de 1939

Já ao final de 1940, respectivamente em 10, 12 e 13 de dezembro, foram publicados o Decreto n. 2.852, o Decreto n. 6.596 bem como o Decreto n. 6.597. O primeiro concentrou a fiscalização das Caixas e Institutos no Departamento de Previdência Social. O segundo compilou as normas processuais sobre competências e recursos relativas ao CNT. Já o terceiro revela a crescente complexidade que tomava a "questão social" à época. O Departamento de Justiça do Trabalho ganhava duas Seções Especializadas, respectivamente, em dissídios individuais e dissídios coletivos. Uma Seção de Administração Judiciária ficaria responsável pelo registro e pela constituição das Juntas de Conciliação e Julgamento, além de assumir competências correicionais sobre atos das Juntas e Conselhos Regionais (artigo 53).

O Departamento de Previdência Social seria ainda composto de uma Seção de Controle Patrimonial (artigo 54, parágrafo $2^{\circ}$, inciso II), de uma Divisão Imobiliária (artigo 
54, parágrafo $4^{\circ}$ ) e de uma Divisão Atuarial (artigo 54, parágrafo $5^{\circ}$ ), dada a premente necessidade de "velar pela liquidação do ativo a realizar dos Institutos e Caixas". O patrimônio das Caixas e Institutos se agigantava, mas assim também o volume de benefícios e prestações devidas. A necessidade controle e de zelo pela rentabilização adequada dos ativos estava na origem de tais mudanças no desenho do CNT.

Em 14 de outubro de 1941 novas mudanças viriam por meio do Decreto n. 3.710. Ao recém-criado Conselho Atuarial do Ministério do Trabalho, Indústria e Comércio foram atribuídas as funções de fixar valores de benefícios, de contribuições e de taxas de juros, antes cometidas à Câmara de Previdência Social.

No início de 1946 o desenho institucional do CNT começaria a sofrer um refluxo, correspondente a uma diminuição da complexidade burocrática. Por meio do Decreto n. 8.737, de 19 de janeiro de 1946, as Câmaras de Justiça do Trabalho e de Previdência Social bem como as Seções especializadas são extintas, mantendo-se apenas o Conselho Pleno, composto por apenas nove membros. A Câmara de Previdência Social foi transformada em Conselho Superior da Previdência Social pelo Decreto n. 8.738, de 19 de janeiro de 1946.

Dessa forma, percebe-se que, à multiplicação das atribuições do Conselho Nacional do Trabalho, ainda no fim da República Velha, correspondeu um consequente crescimento de sua estrutura que, ao longo da Era Vargas, foi-se tornando mais complexa. Em 1923, o órgão contava com um Conselho Pleno (composto por 12 membros), uma Secretaria do Conselho Nacional, uma Biblioteca e um Museu. Já em 1940, além do Pleno (composto por 18 membros), o CNT passou a ser composto por uma Câmara de Justiça do Trabalho que, dentre outras competências, deveria julgar os dissídios coletivos que excediam a jurisdição dos Conselhos Regionais do Trabalho bem como julgar os recursos ordinários e extraordinários das decisões proferidas pelos Conselhos Regionais do Trabalho. Também integrava o Conselho Nacional do Trabalho uma Câmara de Previdência Social, órgão orientador e fiscalizador das administrações dos Institutos e Caixas de Aposentadoria e Pensões; uma Procuradoria da Justiça do Trabalho; uma Procuradoria da Previdencia Social; um Departamento de Justiça do Trabalho; uma Seção de Administração Judiciária e muitos outros departamentos e seções.

Foi só em 1939, contudo, que a Justiça do Trabalho foi organizada com este nome, por meio dos Decretos-lei de números 1.237 e 1.346, que também reorganizaram o CNT, então seu órgão de cúpula. Compunham-na também as Juntas de Conciliação e Julgamento, instituídas em 1932, por meio do Decreto n. 22.132, e os Conselhos Regionais 
do Trabalho. A efetiva implantação da Justiça do Trabalho veio apenas em 01 de maio de 1941.

A Justiça do Trabalho, no entanto, só passou efetivamente para o âmbito do Poder Judiciário com a Constituição de $1946^{59}$. Antes da promulgação da Constituição de 1946, contudo, a nova estrutura já constava do Decreto-lei n. 9.797, de 9 de setembro de 1946, por meio do qual o Conselho Nacional do Trabalho convertia-se em Tribunal Superior do Trabalho, e os Conselhos Regionais do Trabalho em Tribunais Regionais do Trabalho, continuando as Juntas de Conciliação e Julgamento com a mesma denominação.

${ }^{59} \mathrm{Cf}$. artigos 94 e 122 e ss., da Constituição de 1946. 


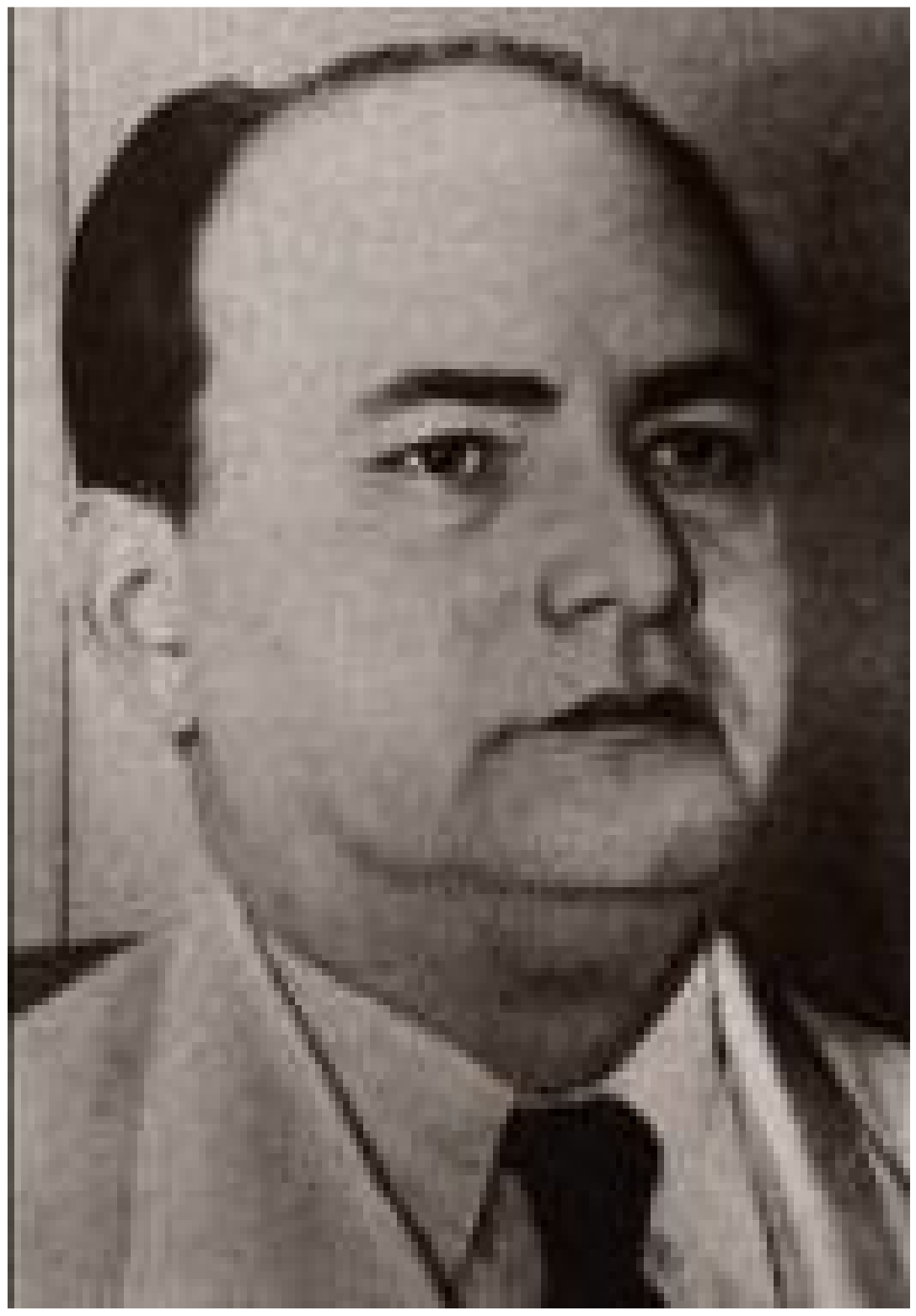

Fotografia 3 - Ministro Agamenon Magalhães

Fonte: $\quad<$ http://aagamenonmagalhaes.blogspot.com.br/2010/02/arte-literatura-helenaconserva-coluna.html> 


\title{
3 A Distribuição de JUSTIÇA PELO CONSElHO NACIONAL do TRABALHO E O PROCESSO DE AFIRMAÇÃo BUROCRÁTICA DO "NOVO DIREITO"60
}

Como já visto, a decisão de criar órgãos estatais voltados ao objetivo de solucionar conflitos do trabalho tem raízes na necessidade de garantir a estabilidade da mão de obra demandada pela intensificação da industrialização brasileira, embora ao longo dos anos 1920 as propostas de regulação e ações referentes ao trabalho tenham sido tímidas e pouco efetivas. Samuel Fernando de Souza, após a análise de documentos relacionados e processos do CNT dos anos 1920, constatou que a tímida regulamentação era frequentemente justificada pelos agentes políticos com um argumento consistente em minimizar a relevância dos conflitos de trabalho no Brasil ${ }^{61}$ :

\begin{abstract}
"A idéia de que havia condições peculiares ao nosso meio foi muito comum na argumentação dos opositores da regulamentação do trabalho ao longo dos anos 1920. Para negar a existência de conflitos entre patrões e operários, com o que pretendiam evitar a urgência na elaboração de medidas que interferissem nas relações de trabalho, os opositores à regulamentação avaliavam que a incipiente indústria brasileira, nas primeiras décadas do século XX, não possuía mercado suficiente para gerar atividades produtivas permanentes e, portanto, não era capaz de produzir a condição primordial do conflito de classe de um grupo sobre o outro, dado que os trabalhadores das indústrias eram, em sua maioria, prestadores de serviços. Conseqüentemente, o tempo de trabalho, exercido pelos trabalhadores no Brasil, obedecia à restrita demanda do mercado, não conformando, assim, relações regulares de trabalho. Os defensores deste ponto de vista estavam, na maioria das vezes, ligados aos setores de produção industrial no Brasil.

Pupo Nogueira, árduo defensor da liberdade de ação dos patrões, fez da sua habilidade de escrita um relevante instrumento de resistência aos projetos de regulamentação propostos no legislativo. Esta regulamentação, sabidamente, modificaria a liberdade com que os patrões exploravam a força de trabalho.

De acordo com Pupo Nogueira, a questão social no Brasil não tinha a mesma relevância que em países europeus, de onde apareciam as principais inspirações de regulamentação. O esforço de guerra havia criado uma situação específica nas relações de classe naqueles países,
\end{abstract}

\footnotetext{
${ }^{60}$ A expressão aparece em diversos artigos jurídicos de revistas especializadas da época. Trata-se de uma referência ao chamado direito social, que englobava os ramos que hoje conhecemos como direito do trabalho e direito previdenciário. Cf., v.g., PIMPÃO, Hirosê. Espírito do novo direito. Revista do Trabalho, ano X, n. 2, p. 11, fev. 1942. A denominação direito industrial aparece em FERNANDES, Adaucto. Direito industrial brasileiro. Rio de Janeiro: A. Coelho Branco Filho Editor, 1938.

${ }^{61}$ SOUZA, Samuel Fernando de. "A questão social é, principalmente e antes de tudo, uma questão jurídica": o CNT e a judicialização das relações de trabalho no Brasil. Cad. AEL, v. 14, n. 26, 2009. Disponível em: http://segall.ifch.unicamp.br/publicacoes_ael/index.php/cadernos_ael/article/view/51/52. Acesso em: 2 dez 2011.
} 
onde foram adotadas soluções que não se aplicavam, definitivamente, ao Brasil. Aqui, por outro lado, o trabalhador recém-chegado do campo, sem uma cultura industrial formada, deveria ser estimulado a fixar-se no emprego e reproduzir sua força de trabalho. A intervenção nas relações de trabalho deveria ser convertida em obras e benefícios sociais. Isto resultaria na composição de uma massa de operários ordeiros que trabalhariam em perfeita harmonia".

Contudo, Souza também mostra que os trabalhadores, à míngua de instituições aptas a receberem suas demandas, direcionavam consultas, cartas e petições ao CNT, que nos anos 1920 tinha atribuição consultiva, com o acesso a ela restrito ao Governo. O movimento crescente do CNT aumentou a pressão para que o desenho do órgão fosse alterado de modo a atender ao fluxo ${ }^{62}$. A pressão dos trabalhadores foi paulatinamente tirando a regulamentação das relações de trabalho e o respeito às leis criadas da claudicância.

Concentrar a decisão dos conflitos trabalhistas no Poder Executivo foi uma decisão natural da política varguista sobre as relações de trabalho. Tratava-se de centralizar a contenção de toda e qualquer possibilidade de conflito que pudesse impedir ou prejudicar o processo de industrialização em curso, imunizando o sistema da política regional. Assim, nos anos 1930 o rol de atribuições e competências do CNT foi largamente ampliado, de modo a atender a esse desígnio.

O material produzido pelo órgão no período pós-1934, analisado na íntegra ao longo do trabalho de pesquisa, compreende:

(i) 45 (quarenta e cinco) processos referentes a servidores e membros do CNT, das Juntas e dos Conselhos Regionais, do período de 1940 a 1946;

(ii) 16 (dezesseis) processos referentes à criação e instalação de Juntas de Conciliação e Julgamento, do período de 1941 a 1946;

(iii) 3 (três) processos contendo comunicados internos, ofícios aos Conselhos Regionais e respectivas respostas, dos anos de 1942 e 1943;

\footnotetext{
${ }^{62}$ Souza cita os relatórios de atividades do Ministério da Agricultura, Indústria e Comércio de 1923 e 1924 , nos quais estão expostos o crescente aumento de pedidos de soluções de "casos" encaminhados por trabalhadores de todo o Brasil. Em 1924, para não haver embaraços à atividade do CNT, foi tomada a decisão de fechar a sua secretaria ao recebimento de novos pedidos. Cf. UNIVERSIDADE DE CHICAGO. Relatório do Ministro da Agricultura, Indústria e Comércio. 1923. Arquivos Brasileiros. Disponível em: $<$ http://brazil.crl.edu/bsd/bsd/u2019/000325.html $>$. Acesso em: $11 \mathrm{dez} 2011$; e, UNIVERSIDADE DE CHICAGO. Relatório do Ministro da Agricultura, Indústria e Comércio. 1924. Arquivos Brasileiros. Disponível em: <http://brazil.crl.edu/bsd/bsd/u2020/000453.html>. Acesso em: 11 dez 2011.
} 
(iv) 3 (três) processos sobre registro de entidades previdenciárias, dos anos de 1939 e 1944;

(v) 33 (trinta e três) livros de atas de sessões das Câmaras e do Conselho Pleno do CNT, do período de 1931 a 1944;

(vi) 3 (três) livros de registro das portarias expedidas pela Presidente do CNT, do anos de 1940, 1942 e 1944;

(vii) 7 (sete) processos contendo relatórios de atividades enviados pelos Conselhos Regionais do Trabalho, do período de 1938 a 1946;

(viii) 6 (seis) livros contendo os registros de posse dos membros do CNT, de servidores, de contratados e de ajudantes técnicos, do período de 1923 a 1946;

(ix) 28 (vinte e oito) processos contendo prontuários de servidores, do período de 1931 a 1946;

(x) 8 (oito) processos relativos a inventário patrimonial, aquisição de mobiliários para as instalações do CNT e para a implementação da Justiça do Trabalho, do período de 1932 a 1942;

(xi) 1 (um) processo apartado (17.011/1936) movido por alguns dos empregados do Bank of London \& South America Limited, em face do British Bank editado em 1937, na forma de um livro, pelos advogados do British Bank, que o defendiam da alegação de sucessão trabalhista;

(xii) 857 (oiticentos e cinquenta e sete) dissídios apresentados ao CNT, distribuídos por 109 caixas, do período de 1933 a 1946.

Há ainda, sob guarda do Tribunal Superior do Trabalho, 50 (cinquenta) livros de acórdãos do Conselho Nacional do Trabalho, do período de 1928 a 1946, ainda não digitalizados. Trata-se de material não consultado, assim como os processos contendo comunicados, portarias, atas de sessões e registros de entidades previdenciárias.

Além do material produzido pelo próprio CNT, foi também analisado o que se segue:

(i) a coleção de 28 (vinte e oito) volumes editada pela Imprensa Nacional à época contendo jurisprudência selecionada das Juntas, dos Conselhos Regionais e do CNT; 
(ii) volumes da Revista do Trabalho, de 1934 a 1946, contendo artigos doutrinários, jurisprudência comentada e atualização legislativa.

Outros materiais foram analisados, tais como manuais, comentários à legislação, estatutos de entidades de previdência, repositórios de legislação, relatórios ministeriais bem como discursos de Getúlio e de seus ministros, oportunamente citados ao longo do texto.

O presente capítulo se presta a expor os resultados da análise desse extenso material, e busca relacionar o discurso de julgados, artigos e textos jurídicos aos atores que os produziram e propagandearam, bem como ao contexto sociopolítico da época ${ }^{63}$.

O foco principal da análise foi depositado sobre os processos que contêm as reclamações de trabalhadores e os inquéritos para a apuração de falta grave sujeitos à revisão do CNT. Trata-se da fonte mais extensa e rica de informações de todo o material pesquisado, e por isso foi escolhido para ter a maior atenção. O material relativo à criação de Juntas e os relatórios de atividades dos Conselhos Regionais é de grande interesse, inclusive para fins quantitativos, mas não foi possível ampliar o objeto da pesquisa de modo a contemplá-los. O mesmo se pode dizer dos registros sobre servidores e patrimônio.

$\mathrm{O}$ processo de liquidação do British $\mathrm{Bank}^{64}$ poderia render por si só um capítulo ou toda uma dissertação. A discussão sobre a responsabilidade por direitos e verbas trabalhistas na sucessão de empresas, em períodos de saúde financeira do empreendimento abalada ou em sua extinção é matéria que até os dias de hoje rende intensas discussões dogmáticas. As peças e arrazoados dos advogados do British Bank bem como as decisões do CNT revelam uma sofisticação dogmática ímpar no universo de reclamações analisado. Foi discutida a configuração do grupo econômico no direito comercial e suas repercussões no âmbito dos contratos de trabalho, especialmente naqueles gravados com a cláusula da estabilidade decenal. Os dois bancários reclamantes fizeram-se representar pelo sindicato da categoria, enquanto o banco constituiu os advogados Antenor Vieira dos Santos e Julio Santos Filho. O banco levou também aos autos pareceres atacando a "legislação revolucionária" e defendendo o direito do sucessor de despedir, encomendados ao Ministro do Supremo Tribunal Federal Pires e Albuquerque ${ }^{65}$, à época

\footnotetext{
${ }^{63}$ Todas as transcrições das fontes são fiéis à grafia dos documentos.

${ }^{64}$ CNT, Processo n. 17.011/1936.

65 “ANTONIO JOAQUIM PIRES DE CARVALHO E ALBUQUERQUE, (...) [E]m decreto de 16 de maio de 1917, foi nomeado Ministro do Supremo Tribunal Federal, preenchendo a vaga ocorrida com o falecimento de Manoel José Murtinho; tomou posse a 26 do referido mês. (...) O Ministro Pires de
} 
aposentado compulsoriamente pelo governo provisório de Vargas ${ }^{66}$, e ao advogado Levi Carneiro $^{67}$, destituído do mandato de deputado constituinte pelo golpe que levaria ao Estado Novo. Essas credenciais igualmente colocam o processo de liquidação do British Bank na agenda da pesquisa historiográfica jurídica, mas optou-se pelo não aprofundamento da análise desse caso.

A maior parte dos processos se refere à análise da legalidade de dispensas de empregados com mais de dez anos de serviço levada à cabo pelos empregadores, com ou sem inquérito processado antes perante as Caixas de Aposentadoria e Pensões, dada a restrição na competência do CNT. As Juntas e Conselhos Regionais se viam às voltas com questões as mais diversas, como a contagem de períodos aquisitivos de férias, a incorporação das gorjetas, a base de cálculo do adicional de insalubridade, a forma de pagamento das horas extras do tarefeiro, a compatibilidade entre o mandato e o contrato de trabalho ${ }^{68}$, a acumulação de pensões das caixas, a proteção do trabalho artístico em cassinos, a ilegitimidade da bígama para pleitear pensão ${ }^{69}$ bem como os requisitos para concessão do seguro-velhice ${ }^{70}$. Vários dos acórdãos dos Conselhos Regionais, das Câmaras

Albuquerque foi aposentado pelo Decreto $\mathrm{n}^{\circ}$ 19.711, de 18 de fevereiro de 1931, ato discricionário do Chefe do Governo Provisório. Publicou, em 1934, o livro Culpa e Castigo de um Magistrado, relatando as circunstâncias que haviam inspirado a sua aposentadoria, em virtude da atuação no cargo de ProcuradorGeral”. Cf. STF. MINISTROS. Antonio Joaquim Pires de Carvalho e Albuquerque. Verbete biográfico disponível em < http://www.stf.jus.br/portal/ministro/verMinistro.asp ?periodo=stf\&id=118>. Acesso em: 04 set 2012 .

${ }^{66}$ Decreto n. 19.711, de 18 de fevereiro de 1931. O Chefe do Governo Provisório da República dos Estados Unidos do Brasil:

Considerando que o decreto n. 19.656, de 3 de fevereiro de 1931, reduziu o número de ministros do Supremo Tribunal Federal $\left(\operatorname{artigo} 1^{\circ}\right)$;

Considerando que imperiosas razões de ordem pública reclamam o afastamento de ministros que se incompatibilizaram com as suas funções por motivo de moléstia, idade avançada, ou outros de natureza relevante;

Decreta:

Art. $1^{\circ}$ São aposentados, com as vantagens que lhes assegura a legislação vidente, dispensado o exame de sanidade, os ministros Godofredo Cunha, Edmundo Muniz Barreto, Antonio C. Pires e Albuquerque, Pedro Affonso Mibieli, Pedro dos Santos e Geminiano da Franca.

Art. $2^{\circ}$ Revogam-se as disposições em contrário.

${ }^{67}$ Levi Carneiro foi um dos fundadores da Ordem dos Advogados do Brasil e ocupou uma cadeira na Academia Brasileira de Letras. Cf. ACADEMIA BRASILEIRA DE LETRAS. Levi Carneiro. Verbete biográfico disponível em: <http://www.academia.org.br/abl/cgi/cgilua.exe/sys/start.htm?sid=271>. Acesso em: 06 set 2012.

${ }^{68}$ Eram comuns as discussões sobre a caracterização própria do contrato de trabalho bem como sobre sua (in)compatibilidade com contratos típicos de direito privado. Cf., v.g., BRASIL, Jurisprudência: Conselho Nacional do Trabalho, v. XXVIII, Rio de Janeiro, Imprensa Nacional, 1946, pp. 29 e ss.

69 BRASIL, Jurisprudência: Conselho Nacional do Trabalho, v. XXVIII, Rio de Janeiro, Imprensa Nacional, 1946, pp. 42-44.

70 BRASIL, Jurisprudência: Conselho Nacional do Trabalho, v. XXVIII, Rio de Janeiro, Imprensa Nacional, 1946, pp. 44 e ss. 
e do Pleno do Conselho Nacional do Trabalho adotavam a estrutura tríplice de relatório, consideranda e dispositivo ${ }^{71}$.

Boa parte dos julgados das Câmaras de Previdência Social prestavam-se a resolver conflitos entre as Caixas e seus segurados, incluindo os casos em que aquela se punha no papel de financiadora de habitações populares.

\title{
3.1 Sobre a pesquisa de processos jurídicos
}

A análise de autos de processos é uma atividade exaustiva, mas bastante reveladora não só do conflito ali tratado, mas de todo o contexto socioeconômico que em torno dele gravita. Se o que não está nos autos não está no mundo, segundo o velho brocardo jurídico, muito do que está nos autos traz luz a aspectos específicos das narrativas mais gerais sobre o mundo.

O processo é documento histórico oficial escrito, tirado em linguagem técnicojurídica, por um rol mais ou menos amplo de personagens, entre eles as partes, os julgadores, pareceristas e servidores do quadro burocrático do órgão em que tramita.

Fabiana Luci de Oliveira e Virginia Pereira da Silva levantam dois problemas metodológicos que advém da análise de processos:

\begin{abstract}
"Se quisermos classificar o tipo de pesquisa feita a partir da utilização de processos judiciais, a primeira definição é a de pesquisa documental. Processos são documentos históricos e oficiais, e o trabalho com esses documentos traz, ao menos, duas implicações metodológicas: a questão do poder e a da interpretação. Estes questionamentos surgem principalmente quando se trabalha qualitativamente com os dados, quando a preocupação está em buscar a lógica e os códigos que estão informando as palavras para inferir sobre grupos sociais específicos" ${ }^{\text {"72 }}$.
\end{abstract}

As questões do poder e da interpretação surgem da linguagem específica emitida por um corpo de julgadores técnicos que agem em nome do Estado ${ }^{73}$. A atenuação

\footnotetext{
${ }^{71}$ BRASIL, Jurisprudência: Conselho Nacional do Trabalho, v. XXVIII, Câmara de Justiça do Trabalho, Processo n. 16.564-44, pp. 19-20.

72 OLIVEIRA, Fabiana Luci de, SILVA, Virginia Pereira da. Processos judiciais como fonte de dados: poder e interpretação. Sociologias, Porto Alegre, ano 7, n. 13, jan/jun 2005, p. 245. Disponível em: http://www.scielo.br/pdf/soc/n13/23563.pdf. Acesso em: $12 \mathrm{dez} 2011$.

73 "Como se trata de um documento oficial, a questão do poder aparece porque o Estado pode ser considerado o verdadeiro produtor do que está escrito, encobrindo a expressão de qualquer grupo social que esteja contida
} 
dos efeitos adversos de tais problemas no presente trabalho se dá pela busca de elementos extraprocessuais que dialogam diretamente com o conteúdo dos processos analisados, seja para confirmá-los, infirmá-los ou adicionar-lhes dados e informações, sempre que possível. Outro caminho buscado foi o da pesquisa sobre os personagens dos processos, no intuito de atribuir-lhes suas filiações político-ideológicas, seu campo de atuação fora do processo e saber das relações entre eles. Assim, se não é possível captar o acontecimento por si, mas sim apenas por intermédio da linguagem mediada dos processos, ao menos uma característica particular de vários dos processos analisados também colabora para uma diminuição da subjetividade da interpretação: a reclamação levada aos órgãos de distribuição de justiça em matéria de relações de trabalho pelo próprio trabalhador, sem o intermédio de advogados ou serventuários. E essa era a situação de muitos dos trabalhadores que apelavam ao CNT para a solução dos conflitos levados ao julgamento do órgão, como se verá adiante. Um outro dado particular aos processos do CNT é a elevada interferência da burocracia no andamento dos processos. A cada encaminhamento interno o servidor remetente faz um resumo do que consta dos autos e muitas vezes opina sobre qual deve ser o deslinde da questão, sempre "salvo melhor juízo".

Colocada essa brevíssima introdução sobre limites e opções metodológicas, passa-se propriamente aos resultados encontrados ao longo da análise dos processos.

\subsection{Os processos do CNT - 1934-1946}

Ainda em 1933, após dez anos de funcionamento do CNT, chegavam ao órgão os mais diversos pleitos relacionados ao mundo do trabalho. Sabino Moreira da Silva, demitido da Companhia Paulista, quando contava com 3 (três) anos de serviços na "Linha Mogyana" na altura de Ribeirão Preto, encaminhou carta ao Ministro do Trabalho, Indústria e Comércio, em 8 de maio de 1933, com o seguinte teor:

no documento em forma de um depoimento, por exemplo, ou mesmo na argumentação do juiz que, além de membro de um dos poderes do Estado também pode ser visto como membro de uma corporação profissional. Já a questão da interpretação surge porque estamos trabalhando com o que está escrito e não, com o acontecimento em si, ou ainda porque não estamos interpretando por meio da observação direta, mas por meio da palavra escrita, e isto é fonte de inúmeros questionamentos, que envolvem a questão da subjetividade." Cf. OLIVEIRA, Fabiana Luci de, SILVA, Virginia Pereira da. Processos judiciais como fonte de dados: poder e interpretação. Sociologias, Porto Alegre, ano 7, n. 13, , p. 245, jan-jun 2005. Disponível em: http://www.scielo.br/pdf/soc/n13/23563.pdf. Acesso em: 12 dez 2011. 
"Sabino Moreira da Silva trabalhando na companhia paulista a quatro anos 8 mez di trabalho si achou doenti i foi dispensado da companhia paulista pelo atestado do médico (...). Peso V.S. ver si aranja um imprego dipois" ${ }^{, 74}$.

Um diretor de seção do CNT encaminhou os autos ao Procurador Geral para a emissão do parecer, que recomenda oficiar o reclamante para que traga aos autos prova do tempo de serviço, ressalvando que o CNT só poderia atuar se contasse com mais de dez anos de serviços na mesma empresa, nos termos do artigo 53, do Decreto n. 20.465, de 1 de outubro de $1931^{75}$, a regular o regime da estabilidade decenal à época. Por ordem do presidente do CNT o ofício é expedido ainda em junho de 1933. A carta e os autos jamais chegaram às mãos do Ministro Joaquim Pedro Salgado Filho ${ }^{76}$, e nada mais consta do processo após o comprovante do envio do ofício.

A solicitação quase desesperada de Sabino revela ao mesmo tempo uma escassez de instâncias para o trato dos problemas referentes às relações de trabalho, seja no âmbito do Estado seja no âmbito da sociedade civil, mas também mostra que começava a circular na cultura operária a notícia da existência de um órgão destinado à proteção de direitos do trabalho. É provável que a propaganda getulista em torno da legislação trabalhista tenha chegado ao conhecimento de Sabino, que não hesitou em encaminhar seu pleito diretamente à mais alta autoridade conhecida, em um dia no início do mês de maio, quando eram comuns as solenidades populares de exaltação a Vargas e de suas realizações no campo do trabalho.

Em 1934, como já exposto, a conformação do CNT sofre alterações e vão se tornando paulatinamente mais técnicos e próximos de seu campo competencial os pleitos a ele direcionados. Pedidos como os de Sabino, comuns nos anos 1920, vão se tornando mais escassos $^{77}$. Todavia, ainda há em 1934 processos de consulta ao Conselho Nacional do

\footnotetext{
${ }^{74}$ CNT, Processo n. 5.313/1933, fl. 2.

75 Art. 53. Após dez anos de serviço prestado à mesma empresa, os empregados a que se refere a presente lei só poderão ser demitidos em caso de falta grave, apurada em inquérito, feito pela administração da empresa, ouvido o acusado com a assistência do representante do sindicato da classe, cabendo recurso para o Conselho Nacional do Trabalho.

${ }^{76}$ Joaquim Pedro Salgado Filho sucedeu Lindolfo Collor no Ministério do Trabalho, ocupando a chefia da pasta de abril de 1932 a julho de 1934. Salgado Filho provinha dos quadros da polícia política varguista, tendo ocupado a $4^{\mathrm{a}}$ Delegacia Auxiliar, responsável pela investigação dos crimes contra a ordem política e social. Foi em sua administração que foram editada quase toda a legislação sobre relações de trabalho e sobre mecanismos institucionais para lidar com os conflitos decorrentes. Cf. GOMES, Angela de Castro. A invenção do trabalhismo. $3^{\mathrm{a}}$ ed. Rio de Janeiro: Editora FGV, 2005, p. 164.

77 No Diário Oficial de 23 de agosto de 1934 (p. 17.418) foi publicada a decisão de arquivamento do Processo 8.185/1934, em que "[U]m anonymo" pedia "a reforma do art. 31 do decreto numero 20.465".
} 
Trabalho. A Companhia Paulista de Estradas de Ferro consulta o $\mathrm{CNT}^{78}$ a respeito da possibilidade de demissão do empregado Domingos Teixeira Pinto sem prévio inquérito administrativo, por ter sido ele condenado à pena de dois anos de prisão, por sentença transitada em julgado do Tribunal do Júri da comarca de Rio Claro. O CNT responde negativamente à consulta, determina a abertura do inquérito e a concessão de prazos em dobro para a defesa no inquérito. Processado o inquérito, conclui este pelo não cometimento de falta grave pelo empregado, uma vez que o crime não tinha relação com seu trabalho na Companhia Paulista. Houve então reintegração tão logo o empregado obteve o livramento condicional.

No caso, o CNT ensaia o exercício de uma função criadora de normas sobre as relações de trabalho, ao ordenar a concessão de prazos em dobro para a defesa do empregado estável no inquérito a ser processado. O acúmulo da experiência na análise dos inquéritos, cuja tramitação era controlada por estrutura disponibilizada pelo empregador, levou o CNT a emitir instruções sobre o processamento dos inquéritos, de modo a fazer cumprir garantias de contraditório, exercício de defesa pelo empregado, comunicação dos atos, atendimento a formalidades, produção de provas.

A criação de normas pelo CNT vinha necessariamente travestida de medida de proteção ao direito à estabilidade decenal, ao menos no período em que a competência central atribuída ao órgão se restringia praticamente à análise da legalidade dos inquéritos para a apuração de falta grave dos empregados estáveis de diversas categorias profissionais. Logo, era natural que todo o raciocínio protetivo - seja para restringir ou para ampliar direitos - passava pela construção de um discurso jurídico justificador em torno da estabilidade. Esse avanço era necessário, ainda que sujeito a críticas a respeito de sua juridicidade, uma vez que igualmente avançavam as formas de fraude ao regime da estabilidade.

31. Em caso de falecimento do associado ativo ou do aposentado, que contar cinco ou mais anos de serviço efetivo, terão direito à pensão os membros de sua família.

$\S 1^{\circ}$ Para os fins da presente lei, consideram-se membros da família do associado, para fazerem jus à pensão, na ordem sucessiva abaixo indicada, se tiverem vivido, até à morte do mesmo na sua dependência econômica exclusiva:

1. mulher, marido inválido, filhos legítimos, legitimados, naturais (reconhecidos ou não) e adotados legalmente; 2 . pai inválido e mãe viúva; 3 . irmãs solteiras.

$\S 2^{\circ}$ A existência de beneficiários de uma qualquer das classes enumeradas no $\S 1^{\circ}$ exclui do benefício qualquer dos membros das classes subseqüentes.

$\S 3^{\circ} \mathrm{O}$ associado que não tiver herdeiro na forma do presente artigo poderá, mediante declaração expressa, do seu próprio punho, com testemunhas, firma reconhecida e registro respectivo, instituir herdeiro, para o fim deste artigo, outro perene do sexo feminino, até $3^{\circ}$ grau, devidamente comprovado, que viva sob sua exclusiva economia.

${ }^{78}$ CNT, Processo n. $2.130 / 1934$. 
Em processo movido pelo ferroviário Raul Zenha de Mesquita em face da Estrada de Ferro São Paulo-Rio Grande, este reclamava ao CNT da concessão pela Estrada de uma licença por tempo indeterminado, com prejuízo de vencimentos, que jamais havia sido requerida. A determinação da Estrada fora emitida no período em que a rede estava ocupada pelos revolucionários de 1930, ali mantidos por ato do Governo Provisório. Mesquita era empregado da Estrada desde 1923.

A reclamação deu entrada no CNT em 12 de abril de 1934, isto é, um ano após o termo final da aquisição da estabilidade por parte de Mesquita. Se em casos de suspensão de até noventa dias o CNT as vinha considerando legítimas expressões do poder de direção do empregador ${ }^{79}$, no caso de Raul Mesquita aflorou a necessidade de uma intervenção mais aguda. A Primeira Câmara do Conselho Nacional do Trabalho considerou implementada a estabilidade, ainda que não houvesse efetiva prestação de serviços por parte do reclamante desde janeiro de 1930, e assim decidiu:

\begin{abstract}
"Considerando que, no caso, não se trata de dispensa e sim de afastamento do serviço sem causa justificada, meio que as empresas, muitas vezes, empregam com o unico intuito de perseguir empregados zelosos e cumpridores de seus deveres ou de evitar que attinjam elles o limite fixado para o direito à estabilidade no cargo;

Resolvem os membros da $1^{\text {a }}$ Câmara do Conselho Nacional do Trabalho julgar procedente a presente reclamação, para o effeito de reconhecer ao supplicante o direito que lhe assiste ao exercicio de sua funcções, determinando à Estrada que faça cessar a situação de licenciado em que se encontra o reclamante., 80
\end{abstract}

Tanto o Pleno do CNT quanto o Ministro, em sede de avocatória, mantêm a decisão da Primeira Câmara, que não é cumprida pela Estrada. Informado pelo próprio reclamante sobre o não cumprimento, o CNT aplica multa à Estrada. Não há notícia nos autos do cumprimento efetivo da ordem de reintegração bem como do pagamento da multa.

Em inquérito encaminhado pela Viação Férrea do Rio Grande do Sul ${ }^{81}$, o CNT se viu novamente na contingência de adaptar sua competência para impedir um mal maior para o trabalhador e até mesmo para evitar uma decisão em que a heterodoxia estaria

\footnotetext{
${ }^{79}$ Há vários processos em que empregados reclamam de suspensões que consideram longas. Quando elas são menores do que noventa dias o CNT ou se dava por incompetente (por não se tratar de demissão de estável) ou afirmava uma prerrogativa do empregador de aplicar suspensões de até noventa dias, por aplicação analógica do artigo 99, do Regulamento do Instituto de Aposentadorias e Pensões dos Bancários (Decreto n. 54, de 12 de setembro de 1934).

${ }^{80}$ CNT, Processo n. 3.918/1934, fl. 39.

${ }^{81}$ CNT, Processo n. 328/1935, fls. 1-3.
} 
exatamente na aplicação literal da lei. O bagageiro Serafim Motta de Oliveira, acusado de transportar um garrafão de cachaça em um dos trens da empresa, foi condenado, porém não à pena de dispensa, mas sim a um rebaixamento de função - de bagageiro passou a guardafreios. Não houve dispensa, conforme disposto no artigo 53, do Decreto n. 20.465/1931, mas sim a aplicação de uma penalidade mais branda, que não arriscava a estabilidade decenal. O CNT, vendo-se diante de decisão do próprio empregador de não dispensar o empregado condenado em inquérito, acolheu o pedido da Viação Férrea quanto ao rebaixamento de função.

Em outro processo, em que se verificava a legalidade da pena de demissão aplicada ao ferroviário Domingos Pereira pela Rede Mineira de Viação, o CNT avançou na modulação da sanção, dando ao reclamante sorte distinta. O CNT determinou que a reclamada aplicasse penalidade mais branda ao reclamante, por não se verificar que os fatos tratados no inquérito (transporte irregular de madeira e barricas de cal em vagão de lastro) não podiam ser considerados falta grave ${ }^{82}$.

O rigor na análise dos inquéritos é crescente e o CNT passa a não admitir aqueles processados à revelia do empregado (mesmo quando o abandono do posto é alegado) ou sem a promoção das diligências destinadas à correta apuração dos fatos. É o caso do ferroviário Domingos Gomes, "trabalhador de lenha" da Estrada de Ferro Sorocabana, que não concordava com a ordem de sua "remoção para o depósito de Santo Antonio" $"$. A chefia da Sorocabana deu então início a um inquérito para apurar a falta grave de abandono de emprego, em que Domingos Gomes negou o abandono e mencionou estar adoentado, tendo inclusive encaminhado atestado médico sobre as "dores rheumaticas nas mãos" emitido pelo serviço médico da Caixa de Aposentadoria e Pensões dos Empregados da Estrada de Ferro Sorocabana, juntado logo após a publicação em O Estado de São Paulo do "edital de chamada" de Gomes para retornar ao trabalho. Contudo, o consultor jurídico da Estrada afirmou que

"[O]s atestados médicos apresentados pelo acusado para justificar a sua
ausencia do serviço em Santo Antonio não são bastantes para lhe
atenuarem a falta, dados como foram após a data da portaria de abertura
deste inquerito. O de fls. 18 foi passado por médico particular que atesta

${ }^{82}$ CNT, Processo n. 1.667/1934, fls. 80-2. Os autos do inquérito foram remetidos ao CNT. Não houve necessidade de requisição. Todavia, o reclamante relatou que suas testemunhas não foram ouvidas.

${ }^{83}$ CNT, Processo n. 357/1936.

${ }^{84}$ CNT, Processo n. 357/1936, fl. 11. Um segundo atestado, relatando "febres", consta da fl. 18. 
por informação... É, portanto, um documento gracioso. O de fls. 11 não demonstra que o acusado estivesse impossibilitado de viajar."

A Primeira Câmara do CNT determinou a submissão de Domingos Gomes a novo exame médico. O laudo concluiu pela invalidez de Gomes e a CAP deferiu sua aposentadoria. Com isso, a Primeira Câmara do CNT, em 01 de agosto de 1938, julgou improcedente o inquérito e ordenou o pagamento dos vencimentos desde o afastamento do serviço.

A análise acurada dos fatos não distinguia partes. Provado robustamente no inquérito que o empregado acusado faltara por seis meses ao trabalho, o CNT validou a dispensa pela The Rio de Janeiro Tramway Light and Power Company Limited do empregado Otaciano Pereira de Assis. Em defesa, o empregado alegou que uma doença o impedira de comparecer ao trabalho. Testemunhas, no entanto, confirmaram que, na verdade, Otaciano de Assis vinha laborando para outro empregador no período ${ }^{85}$.

A Segunda Câmara foi igualmente rigorosa na análise das provas trazidas aos autos de processo em que a Estrada de Ferro Araraquara acusava Alexandre Rodrigues de ato de improbidade, consistente na apropriação de $19 \$ 200$ (dezenove mil e duzentos réis) referentes a "duas passagens". A prova testemunhal foi considerada "fraca"; a documental (os próprios talões de passagens manejados pelo empregado) foi afastada, por carecer de "um exame pericial, máxime tendo em vista a qualidade do papel, visivelmente inferior", que "poderia dirimir a duvida que a envolve, o que não ocorreu" 86 . O acórdão menciona ainda que

"a fé de ofício do acusado não é inteiramente limpa; a par de anotações
de somenos gravidade, peculiares ao exercício da profissão a que se
dedicou, registra, entre outras, uma suspensão 'por haver chefiado o trem
P6, 15/1, alcoolizado'; entretanto, contrastando, menciona um
significativo louvor por ter entregue 'ao agente da estação de Mirassol,
uma carteira contendo $965 \$ 000$ em dinheiro, a qual foi por êle encontrada
no carro dormitorio E.2, e que pertencia a um passageiro que
desembarcou em Rio Preto."

O conjunto probatório insuficiente e um passado funcional favorável salvaram Alexandre Rodrigues da dispensa.

No processo 564/1939, consta inquérito remetido pela The Manáos Tramways and Light Company movido em face dos fiscais Adelino Medeiros Barbosa, João Manoel

\footnotetext{
${ }^{85}$ CNT, Processo n. 1365/1940.

${ }^{86}$ CNT, Processo n. $446 / 1937$, fl. 82.
} 
das Neves e Pedro Veríssimo da Silva. A prova testemunhal, que nada esclareceu sobre o alegado conluio dos acusados para o desvio de valores, foi ignorada pela Segunda Câmara do CNT. Foi determinada a reintegração com pagamento dos vencimentos do período de afastamento dos empregados acusados, uma vez que "nem siquer foram suspensos" Assim, a gradação das penalidades passou a ser outro direito acessório à estabilidade incluído na pauta do CNT.

Em outro caso, Antonio Soares, empregado da Saint John d’El Rey Mining Co. Ltd., reclama ao CNT de sucessivas reduções de vencimentos, havidas após ter "levantado um machado" - "num gesto de instintiva defeza de conservação" 88 -, para um empregado dinamarquês que lhe sacou um revólver quando foi reclamar da referida redução de vencimentos (de $30 \$ 000$ para 21\$000, referentes a uma jornada de doze horas diárias). Contando com mais de dezoito anos de serviços prestados para a companhia, recorreu ao sindicato da categoria, União dos Mineiros da Morro Velho e Classes Conexas, sediado em Nova Lima, Minas Gerais, para apresentar sua pretensão. Alguns meses após a condenação no inquérito, a empresa ofereceu a Soares a conversão da dispensa em reintegração sem pagamento de atrasados. O empregado rejeita a proposta e envia carta à companhia informando que aguardaria a decisão do CNT sobre o caso.

$\mathrm{Na}$ petição inicial da reclamação, o CNT é alertado sobre as condições de trabalho locais ("V. Exa. já sabe que os ingleses da Morro Velho exercem nestes rincões um verdadeiro terrorismo"). $\mathrm{O}$ fecho da peça de ingresso busca dar uma dimensão coletiva ao conflito:

\footnotetext{
"Appello para o egregio C.N.T.. O meu direito quero-o inteiro e de accordo com a lei. Nós os seis mil operarios desta empreza depositamos inteira e illimitada confiança na consciencia illibada e integra dos juizes do C.N.T., e sabemos que elle fará cumprir a lei." ${ }^{89}$
}

A empresa então envia o inquérito ao CNT e propõe seja aplicada uma pena de suspensão, "attendendo aos bons antecedentes do queixoso" ${ }^{\text {"90 }}$. O acórdão da Primeira Câmara do CNT não conhece da reclamação quanto à suspensão, sob o fundamento da tolerância quanto a suspensões de até noventa dias; cita leading case do próprio Conselho

\footnotetext{
${ }^{87}$ CNT, Processo n. 564/1939, fl. 52.

${ }^{88}$ CNT, Processo n. 9.588/1936, fl. 2.

${ }^{89}$ CNT, Processo n. 9.588/1936, fl. 3.

${ }^{90}$ CNT, Processo n. 9.588/1936, fl. 64.
} 
sobre o tema (Processo n. 14.321/1933) ${ }^{91}$. Quanto à redução de vencimentos, ordenou a conversão do julgamento em diligência, para esclarecimentos sobre a alegação da Saint John de que a redução se fundava na alteração de função de Soares de "empregado de turma" para "feitor", uma vez que a jurisprudência do Conselho consolidara entendimento segundo o qual "a reducção de vencimentos ou rebaixamento de cargo, com reducção de salarios, são actos que attentam contra a estabilidade funccional"92.

Antonio Soares então constitui o advogado Davydoff Lessa, que inicia uma ação de justificação perante o juízo municipal de Sabará, em que são ouvidas testemunhas sobre a alegada redução de salários. Recebida a justificação, o CNT leva o processo à pauta de 02 de maio de 1938, e julga prejudicada a reclamação quanto à dispensa e à suspensão, uma vez que houve reintegração do reclamante em agosto de 1937. Já quanto à redução de salários sobreveio a improcedência, pois “a redução de vencimentos só é vedada quando praticada como meio de violar a estabilidade funcional"93. A justificação, combinada com informações trazidas pela Saint John, comprovaram que houve apenas a supressão de uma gratificação pelo exercício de uma função adicional, e não supressão de vencimentos.

A tutela da higidez salarial assentada na jurisprudência do CNT continuaria em efeito. Em 4 de janeiro de 1937, Ambrosio Scarpim, Inspetor Geral da Via Permanente, ingressa com reclamação contra a Rede de Viação Paraná-Santa Catharina, que teria lhe reduzido os salários em abril de $1932^{94}$. Após queixa de Scarpim, o Ministro de Viação e Obras Públicas ordenou ao Superintendente da Rede que restituísse o salário do empregado ao patamar anterior, porém nada dispôs sobre a indenização das diferenças do período de redução. A empresa, oficiada, não se manifestou nos autos da reclamação, pelo que a Segunda Câmara do CNT, invocando a jurisprudência do Conselho, determinou o pagamento indenizado das diferenças ${ }^{95}$.

Em 03 de janeiro de 1934, o Capitão Tenente Luiz Carlos de Carvalho, comandante de Primeira Classe do Lloyd Brasileiro dirigiu ao CNT uma petição requerendo sua reinclusão na lista dos comandantes efetivos de sua classe, assegurados

\footnotetext{
${ }^{91}$ O entendimento sobre a incompetência do CNT para conhecer de reclamações contra suspensões de até noventa dias perdurou por longo tempo. Há processos, cuja tramitação invadiu os anos 1940, que ainda o levavam em conta. É exemplo o Processo n. 2.735/1940, que inicia com denúncia encaminhada pela Delegacia do Trabalho Marítimo. Nela o capitão de longo curso do Lloyd Brasileiro, José Moreira Pequeno, reclama de desembarque e suspensão de noventa dias. O CNT não tomou conhecimento da reclamação.

${ }^{92}$ CNT, Processo n. 9.588/1936, fl. 65.

${ }^{93}$ CNT, Processo n. 9.588/1936, fl. 112 do volume apensado.

${ }^{94}$ CNT, Processo n. 144/1937, fl. 2.

${ }^{95}$ CNT, Processo n. $144 / 1937$, fls. $7-8$.
} 
todos os direitos e vantagens decorrentes do cargo. Carvalho fora desembarcado em 1915 do comando do vapor Orion, por tempo indeterminado. O desembarque ocorreu logo após o naufrágio da embarcação, que se deu próximo à Ilha do Macuco, no hoje município de Bombinhas, em Santa Catarina. O naufrágio do melhor navio da frota do Lloyd Brasileiro à época, conforme apurado em inquérito próprio, ocorreu em função da neblina, que impediu o capitão de desviar o navio de um banco de pedras.

Antes do encaminhamento dos autos para o parecer da Procuradoria, foram pedidas informações à Companhia de Navegação Lloyd Brasileiro. A resposta ocupou parcas seis linhas, nas quais o Diretor do Lloyd esclarecia que o desembarque por tempo indeterminado foi ordenado por meio de portaria do Ministro da Fazenda à época do naufrágio, João Pandiá Calógeras. Findo o inquérito, apurou-se que o comandante do Orion não teve culpa no naufrágio.

O Procurador Geral emite parecer no qual observa não ter havido demissão, mas apenas suspensão que, por sua natureza, jamais poderia ser permanente. Termina requerendo que "o Egregio Conselho Nacional do Trabalho se pronuncie reconhecendo que o comandante Luiz Carlos de Carvalho continua para todos os efeitos empregado do Lloyd Brasileiro"96. E o acórdão do CNT, publicado apenas em 25 de julho de 1935, acolhe a opinião da Procuradoria.

Os embargos do Llloyd não são conhecidos com fundamento em matéria processual pela qual o recurso de embargos versando sobre fatos deve estar instruído com documentos novos. Na inexistência destes só cabia a discussão da matéria de direito.

Em 1 de abril de 1936, o comandante Luiz Carlos constitui o advogado Diogo Gomes Xerez ${ }^{97}$ para cuidar do cumprimento total do julgado do CNT. Reintegrado à Seção de Navegação do Lloyd, reclamava os salários do período da suspensão. A companhia assim se manifestou sobre o pleito:

\footnotetext{
"Em face dessa decisão foi o commandante Luiz Carlos de Carvalho, mantido na lista de commandantes desta Companhia, passando a perceber vencimentos que lhe foram pagos desde a data do primeiro accordão, isto é, 25 de junho de 1934.

Maior de 70 anos e afastado das funcções de commando, por portaria do Ministerio da Fazenda, desde 1915, não podia aquelle commandante
}

${ }^{96}$ CNT, Processo n. 48/1934, fl. 29.

97 Xerez ganharia certa notoriedade nos anos 1940 ao atuar na defesa dos direitos autorais reclamados pela família de Bernardo Guimarães, autor de A Escrava Isaura, contra o Jornal do Brasil, que publicara em fascículos, sem autorização, a referida obra, conforme relato de um seu descendente constante de página dedicada à memória do escritor. GUIMARÃES, Armelim. A morte de BG. Disponível em: $<$ http://reocities.com/Athens/olympus/3583/victoria.htm>. Acesso em: 25 out 2011. 
prestar a esta Companhia qualquer serviço, ficando, assim, addido, sem funcções.

Em nenhum dos accordãos ha qualquer referencia a reintegração, vantagens legaes ou atrazados.

Seria, evidentemente, pesadissimo onus para esta Companhia arcar com o pagamento de vencimentos a um empregado do extincto Lloyd Brasileiro - Patrimonio Nacional, pelo periodo em que o mesmo esteve afastado do serviço - cerca de dez annos, situação para a qual não concorreu de modo algum, o actual Lloyd Brasileiro." 98

Sobrevém novo acórdão do CNT, em 1 de outubro de 1936, negando o pagamento dos atrasados, sob o fundamento de que não houve reintegração, mas apenas manutenção do reclamante na lista dos comandantes do Lloyd. Ao que parece, o CNT, embora compreendesse o instituto da sucessão de empresas, houve por bem não atribuir ao provimento declaratório emitido no caso os mesmos efeitos da reintegração.

O questionamento de atos do Estado, como no caso da suspensão aplicada pelo Ministro da Fazenda ao comandante Luiz Carlos ainda em período no qual o Lloyd Brasileiro era empresa estatal, aparece em outros casos.

José Diogo Junior, um ajudante de almoxarife da Estrada de Ferro Goyaz, pede sua reintegração, após ser dispensado sem justa causa pela Estrada, mesmo contando mais de dez anos de tempo de serviço. O ato de dispensa datava de agosto de 1931 e o pedido de reintegração foi apresentado em 31 de janeiro de 1934, pelo advogado Henrique Viegas, militante na comarca de Catalão, em Goiás.

Estabelece-se a controvérsia em torno do tempo de serviço, tendo o reclamante juntado aos autos "certidões de contagem" e a Estrada de Ferro de Goyaz encaminhado ao CNT a sua "fé de ofício" - ficha de registros e averbações de ocorrências havidas ao longo da execução do contrato de trabalho -, na qual se observa admissão em 1 de abril de 1929, com nomeação feita pelo Presidente Washington Luis. Logo em 2 de maio de 1930 foi exonerado por abandono de emprego, retornando à Estrada em 1 de fevereiro de 1931. Desde sua admissão há vários registros de suspensões por erros cometidos em serviço (todas antes de 1930) e várias por indisciplina (todas posteriores a 1930 e à sua volta à Estrada por ato do Governo Provisório). Um mês antes de ser dispensado, por meio de decreto do Chefe do Governo Provisório,

"foi repreendido pelo fato de ventilar assuntos delicados que dizem com a honorabilidade de funcionarios e peculiares a Estrada, com membros de

${ }^{98}$ CNT, Processo n. 48/1934, fl. 57. 
partido politico partidario, agindo nessa qualidade; e pelo fato de procurar ditar normas à Diretoria" 99 .

Para dirimir a controvérsia sobre o tempo de serviço do reclamante, o presidente do CNT ordena a expedição de ofício à Estrada para que esclareça sobre a alegada prestação de serviços desde março de 1912, incluindo uma transferência para a Estrada de Ferro Oeste de Minas. A resposta informa a inexistência de arquivos anteriores a 1920, ano em que a Estrada foi encampada pela União, bem como reafirma a prestação de serviços apenas a partir de 1929.

O acórdão dá por procedente o pedido,

"para o effeito de ser reconhecido a José Diogo Junior o direito à reintegração no cargo pretendido, officiando-se, porem, ao Sr. Ministro da Viação e Obras Públicas no sentido de encarecer a necessidade de ser reparado o acto da administração da Estrada de Ferro de Goyaz. Rio de Janeiro, 18 de dezembro de 1934." 100

Os embargos da Estrada invocam jurisprudência do CNT no sentido de interromper a contagem de tempo de serviço do empregado quando há abandono de emprego, repisam vinte e oito punições dadas ao reclamante por motivos diversos e sustentam a invalidade da certidão de contagem por ele apresentada por não existirem arquivos anteriores a 1920 nos escritórios da Estrada.

Em contrarrazões, José Diogo Junior afirma que sua demissão por abandono de emprego se deu em maio de 1930,

"por questões de ordem politica; pois, como bem o sabe o Egregio Conselho, na republica velha, os funcionários publicos que não comungassem nos mesmos sentimentos politicos dos seus chefes hierarquicos, sofriam toda a sorte de humilhações e perseguições. E foi esse o caso do contestante. Logo que irrompeu a Aliança Liberal no Brasil, empolgado pelo movimento civico chefiado pelos grandes brasileiros - drs. Getulio Vargas e Antonio Carlos Ribeiro de Andrada, a ele se incorporou o contestante de corpo e alma, tendo, nessa ocasião, telegrafado ao Presidente Antonio Carlos, hipotecando-lhe a sua solidariedade politico-revolucionária.

A atitude dessambrada do contestante, naquela época de corrupções e de servilismos, agitou o nucleo 'prestista' da E. F. de Goiaz, nucleo esse chefiado pelo Diretor da Estrada, que passou, em represalia, a exercer contra o contestante forte pressão, chegando, até, a o suspender do

\footnotetext{
${ }^{99}$ CNT, Processo n. 975/1934, fl. 12.
}

${ }^{100}$ CNT, Processo n. 975/1934, fl. 28. 
serviço, sem causa justa, por duas vezes, e, finalmente, a o transferir, repentinamente, para o Escritório do Trafego, em Araguari'”,"101.

A Procuradoria arguiu matéria preliminar de não conhecimento dos embargos por ausência de "argumentos novos" e nota que eles "se reduzem a apresentar inquerito, sem forma regular, em que não foi ouvido o acusado"102. Invoca ainda a aplicação do artigo 18 das Disposições Transitórias da Constituição de 1934, pelo qual restaram aprovados todos os atos do Governo Provisório, excluindo qualquer apreciação judicial a seu respeito ${ }^{103}$. Por isso, o ato de dispensa de José Diogo seria insuscetível de apreciação pelo CNT, embora fosse órgão administrativo, e não instância do Poder Judiciário. Veio ainda aos autos, a pedido da Procuradoria, informação prestada pela Inspetoria das Estradas de Ferro dando conta da transferência da administração da linha FormigaPatrocínio (trecho em que trabalhou o reclamante) da Estrada de Ferro de Goyaz para a Estrada de Ferro Oeste de Minas ${ }^{104}$. Com isso, termina favorável a José Diogo a controvérsia sobre a soma dos períodos laborados. O parecer, contudo, é pelo provimento dos embargos da Estrada. A prova trazida por José Diogo é desqualificada, por não poder ser confrontada com os registros da Estrada, alegadamente inexistentes para o período anterior a 1920. Questiona o Procurador como poderia o contador da própria Estrada ter certificado se os arquivos anteriores a 1920 não mais existiam. Termina assim o parecer:

"Atualmente só compete conhecer do caso a comissão revisora nomeada
para reparação dos atos atentatorios aos direitos individuaes, por ventura
lezados por atos do Governo Provisorio, a cuja porta poderá o embargado
José Diogo Junior ir bater, si assim julgar conveniente."

O acórdão do Pleno do CNT é cópia do parecer da Procuradoria.

José Diogo Junior remete então uma carta de próprio punho a Vargas. O documento, última manifestação do reclamante no processo, contém chancelas da Secretaria da Presidência da República, da Secretaria do Ministério de Viação e Obras

\footnotetext{
${ }^{101}$ CNT, Processo n. 975/1934, fl. 46.

${ }^{102}$ CNT, Processo n. 975/1934, fl. 53v.

103 Art 18. Ficam aprovados os atos do Governo Provisório, dos interventores federais nos Estados e mais delegados do mesmo Governo, e excluída qualquer apreciação judiciária dos mesmos atos e dos seus efeitos. Parágrafo único. O Presidente da República organizará, oportunamente, uma ou várias Comissões presididas por magistrados federais vitalícios que, apreciando de plano as reclamações dos interessados, emitirão parecer sobre a conveniência do aproveitamento destes nos cargos ou funções públicas que exerciam e de que tenham sido afastados pelo Governo Provisório, os seus Delegados, ou em outros correspondentes, logo que possível, excluído sempre o pagamento de vencimentos atrasados ou de quaisquer indenizações.

${ }^{104}$ CNT, Processo n. 975/1934, fl. 57.

${ }^{105}$ CNT, Processo n. 975/1934, fl. 59.
} 
Públicas e do próprio CNT, revelando o caminho percorrido pela missiva. Nela requer o cumprimento do primeiro acórdão, sem ainda saber do provimento dos embargos da Estrada:

\begin{abstract}
"Entretanto, a 19 de julho de 1932, quando a estabilidade governamental revolucionária estava ameaçada pela revolução paulista, fui dos primeiros a organizar o batalhão patriótico de Goiandira - Goiaz, onde me rezido, e, com ele, a marchar para o 'front' paulista, sob o comando do ilustre revolucionário Dr. Nero de Macedo Carvalho, a nossa maior expressão politica em Goiaz, que lhe poderá informar a respeito de minhas alegações. (...)

Entretanto, Exmo. Sr. Dr. Getulio, com tantos serviços prestados à bôa causa nacional e a revolução, que todavia servi com sacrificios de minha familia, que é numerosa, estou lutando com sérios embaraços para conseguir o integral acatamento a respeitavel decisão da nossa mais alta Corte da Justiça Administrativa (...). Por esse motivo, é que tomo a liberdade de vir solicitar de V. Excia. a sua valiosissima proteção a meu respeito, para que eu seja reintegrado no cargo de Ajudante de Almoxarife, ou outro de igual vencimentos, conforme decisão do C. N. Trabalho. Animado pelos serviços que tenho prestado à revolução, e que continuarei a prestar, toda a vês que a autoridade de V. Excia. estiver em xeque, espero que $\mathrm{V}$. Excia. determinará o meu aproveitamento na vaga de Sub-Chefe da Contabilidade, da E. F. de Goiaz, que, presentemente, se acha sem candidato com os direitos adquiridos como eu, isto é, de armas nas mãos, por duas vêzes, na defeza dos postulado revolucionários. Com a devida venia, caso lhe seja possível, solicito a V. Excia. de falar com o nosso ilustre deputado Nero de Macedo Carvalho, sobre o meu caso, o qual dará a V. Excia. todos os esclarecimentos precisos, tanto da minha atuação revolucionária de 30 e 32, como os da minha exoneração ilegal. Com os meus agradecimentos sinceros, peço a V. Excia. perdoar o meu aborrecimento e aceitar os meus vivos cumprimentos respeitosos."
\end{abstract}

Logo após a carta consta dos autos informação prestada pelo Diretor da Estrada de Ferro de Goyaz à Inspetoria Federal das Estradas, sobre a solicitação de ocupar o cargo de subchefe da contabilidade. Informa o Diretor que o cargo não está vago e que os vencimentos não são equivalentes. Rebate ainda a tentativa do reclamante de se valer das gestões do deputado Nero de Macedo Carvalho:

"O illustre deputado Nero de Macedo, a personificação do dynamismo, exemplar e dedicadisimo como é à causa publica, desconhece, por certo, o verdadeiro José Diogo Junior.",106

O processo se encerra com a expedição de notificação da decisão do Pleno ao reclamante.

$\overline{{ }^{106} \text { CNT, Processo n. 975/1934, fl. } 71 .}$ 
Ao fundamento do artigo 18 das Disposições Transitórias da Constituição de 1934 juntou o CNT o argumento da lei especial, para se colocar como incompetente para o julgamento de reclamação em que era autor funcionário público da União lotado na Estrada de Ferro Central do Brasil ${ }^{107}$.

Se no processo de José Diogo Junior o CNT evitou um possível conflito institucional, ao não acolher o pedido de reintegração de empregado dispensado por meio de ato do Governo Provisório, no caso de Benjamin Aprigio Pavão a situação foi distinta, o que mostra o adiamento e não a cessação do choque de instituições do Estado. Em 03 de setembro de $1937^{108}$, Pavão encaminha carta ao Ministro do Trabalho, Indústria e Comércio pedindo fossem baixados os autos à Secretaria do CNT para que houvesse a expedição da carta de sentença destinada à ultimação de sua reintegração aos quadros do Lloyd Brasileiro - Patrimônio Nacional ${ }^{109}$, denominação do Lloyd após a encampação pela União.

O reclamante contava com mais de dez anos de tempo de serviço e fora condenado em inquérito para a apuração de falta grave. O Lloyd, mesmo instado por diversas vezes pela Procuradoria e pelo Presidente do CNT, não enviou os autos do inquérito, mas apenas cópias de um "Livro Histórico" bem como da "fé de ofício" de Pavão, com registro de serviços prestados apenas de 1923 a 1927 e nenhuma referência ao inquérito para a apuração de falta grave ou ao resultado deste. A Primeira Câmara do CNT julgou improcedente o pleito de reintegração, sob o argumento de que a Lei n. 5.109, de 20 de dezembro de 1926, carecia de regulamentação à época da dispensa ( 25 de maio de 1927).

A jurisprudência do CNT vinha oscilando desde 1931 entre a aplicabilidade plena e imediata da Lei n. 5.109/1926 e a necessidade de regulamento. A Lei n. 5.109/1926 estendia aos marítimos e portuários as disposições da Lei Eloy Chaves (Decreto n. 4.682, de 24 de janeiro de 1923) nos seguintes termos:

\footnotetext{
${ }^{107}$ CNT, Processo n. 1.975/1934, fl. 22 e verso. Raul Ribeiro da Costa fora se tratar de cólicas hepáticas na estância de Águas da Prata e foi exonerado por abandono de emprego, sem a realização de inquérito. A exoneração ocorrera em maio de 1929; contudo, a reclamação foi apresentada apenas em 28 de fevereiro de 1934. A demora foi notada em sede de embargos e foi aplicada regra sobre o prazo prescricional de um ano prevista no artigo $6^{\circ}$ do Decreto n. 20.910, de 6 de janeiro de 1932, em vigor até os dias de hoje. Houve voto vencido do conselheiro Luis Augusto do Rego Monteiro, para quem o dispositivo referido pelo relator tinha por fim relações de ordem administrativa e ações contra a Fazenda Pública, e não a legislação social de previdência. A demora na apresentação de reclamação é recorrente nos processos do CNT; contudo, o tema da prescrição aparece pela primeira vez nesse processo. Até então o CNT vinha aceitando reclamações contra dispensas de empregados estáveis apresentadas muitos anos após o ato de desligamento.

${ }^{108}$ CNT, Processo n. 12.908/1937, fl. 3.

${ }^{109}$ CNT, Processo n. 9.345/1934.
} 
"Art. $1^{\circ}$ Todas as estradas de ferro do paiz, a cargo da União, dos Estados, dos Municipios, ou de particulares, terão Caixas de Aposentadoria e Pensões para os seus ferroviarios, regidas pelas disposições da presente lei.

$\S 1^{\circ}$ Os dispositivos da presente lei são extensivos a todas as emprezas de navegação maritima ou fluvial e ás de exploração de portos pertencentes a União, aos Estados, aos municipios e a particulares, em tudo quanto lhes possa ser applicavel."

Contudo, o parágrafo $4^{\circ}$ do mesmo artigo bem como o artigo 75 assim dispunham:

“ $\S 4^{\circ} \mathrm{O}$ Governo expedirá os regulamentos que julgar convenientes para o cumprimento deste artigo, ouvido o Conselho Nacional do Trabalho".

“Art. 75. Para execução desta lei, o Governo expedirá os regulamentos necessarios, ficando autorizado a fazer no decreto n. 16.027, de 30 de abril de 1923, as alterações que julgar convenientes para efficiencia de todos os serviços decorrentes da presente lei e de outras referentes ao Conselho Nacional do Trabalho, podendo despender até a quantia de 150:000\$000.”

A pretensão de Pavão vinha fundada no artigo 43, da Lei n. 5.109, que não continha referência a regulamento posterior:

"Art. 43 . Depois de 10 annos de serviço effectivo o ferroviario, a que se
refere a presente lei, só poderá ser demittido no caso de falta grave
apurada em inquerito feito pela administração da respectiva estrada,
sendo ouvido o accusado, com recurso para o Conselho Nacional do
Trabalho, respeitados os direitos adquiridos.
$\S 1^{\circ}$ Para aquelle que tiver mais de 10 annos, em mais de uma estrada, o
tempo de serviço para os effeitos da vitaliciedade, neste artigo
estabelecido, e só para esse effeito, será calculado mediante accôrdo entre
a estrada de ferro e o ferroviario.
$\S 2^{\circ}$ Nos casos de dispensa do ferroviario, por conveniencia da estrada,
cabe-lhe a vantagem, voltando para os serviços da mesma estrada, de
continuar com todos os direitos, inclusive a contagem do tempo em que
serviu.
$\S 3^{\circ}$ Não se comprehendem neste artigo os cargos de imediata confiança
das administrações, taes como os de directores, gerentes e outros
semelhantes".

Em 31 de dezembro de 1930, sobreveio o Decreto n. 19.554, assim dispondo:

“Art. $3^{\circ}$. É extensiva ao pessoal das empresas de navegação marítima ou fluvial a que se refere o $\S 1^{\circ}$ do art. $1^{\circ}$ do decreto número, 5.109, de 20 de 
dezembro de 1926, a disposição do artigo $2^{\circ}$ do decreto n. 19. 497, de 17 de dezembro de $1930^{110}$."

A Primeira Câmara, acolhendo a tese da necessidade e afirmando a ausência de regulamentação da Lei n. 5.109, julga improcedente o pleito de Aprigio Pavão. Este opõe embargos, invocando julgados que velavam pela aplicação direta do artigo 43, da Lei n. 5.109. Para isso constituiu os advogados Sylvio Rangel e Evaristo da Veiga. A procuradoria também recorre, pleiteando a uniformização da jurisprudência do CNT sobre o tema.

O Pleno do CNT, acolhendo opinião da Procuradoria, reforma o acórdão da Primeira Câmara, determinando a reintegração de Pavão. O voto, construído na forma de consideranda, afasta a interpretação pela qual o artigo 75, da Lei n. 5.109, que tratava apenas da eficiência dos serviços, impediria a plena eficácia do artigo 43 da mesma lei, apoiando-se nos comentários à Constituição de 1891 de Carlos Maximiliano (“É principio geralmente admittido que as disposições que conferem poderes, estabelecem garantias e prescrevem prohibições, independem de regulamento para a sua integral e immediata execução").

Houve voto vencido, pouco consistente, do conselheiro Humberto Smith de Vasconcelos, no qual defendeu a necessidade de regulamentação e atacou a divergência trazida pela Procuradoria:

\footnotetext{
"Quero adduzir, a proposito, mais uma citação além das que foram invocadas pela Procuradoria.

São ensinamentos de Clovis Bevilacqua que 'a lei póde determinar o momento em que se tornará obrigatoria. Assim é que o Codigo Civil, publicado a 1 de janeiro de 1916, sómente 12 mezes depois dessa data entrou em vigor, se dispoz em seu art. 1806'.

A Lei n. 5.109, de 1926, está nesse caso. Embóra publicada em 1926, fez depender a sua applicação de expedição de regulamentos.

(...)

A redacção desse artigo de lei [artigo $2^{\circ}$, do Decreto n. 19554], deixa claro e fóra de qualquer duvida que, até 31 de dezembro de 1930 , o pessoal das emprezas de navegação maritima e fluvial não gozava das regalias do Dec. 5.109.
}

\footnotetext{
${ }^{110}$ Art. $2^{\circ}$ Para os efeitos decorrentes do artigo anterior, todo o pessoal dos aludidos serviços, contando mais de dez anos de antiguidade não poderá ser demitido, salvo caso de falta grave, apurada em inquérito administrativo, cujos autos deverão ser remetidos ao Conselho Nacional do Trabalho, para defesa do acusado. O "artigo anterior" referido estatuía que "[A] partir de 1 de janeiro de 1931, todos os serviços de força, luz, bondes e telefones, a cargo dos Estados, municípios e particulares, e os serviços de telegrafia e radiotelegrafia mantidos por particulares ficarão sujeitos ao regime do decreto n. 5.109 , de 20 de dezembro de $1926 "$.
} 
Si assim não fosse, o referido decreto, não tinha nenhuma razão de ser, isto é, não tinha existido.

Já, no entretanto, com relação ao accordão proferido no Proc. 5.337/931, junto a fls. 48, destes autos, pela Procuradoria Geral, o caso é muito diverso, pois o reclamante por elle beneficiado havia sido demittido em 2 de janeiro de 1931, quando a lei que o amparava fôra promulgada em 31 de dezembro de 1930, lei esta que, nos termos do art. $2^{\circ}$ do Codigo Civil, já tinha o caracter executivo.

A sua publicação se deu, é bem verdade, em 8 de janeiro de 1931, seis dias após a demissão do reclamante, mas esta formalidade, que torna a lei obrigatoria com a sua publicação, não podia affectar de modo algum, um direito já adquirido por força da data da promulgação da Lei - (Cod. Civil art. $2^{\circ}$ citado).,"111

O Lloyd recorre, pedindo a avocação ao Ministro ${ }^{112}$. A uniformização efetuada pelo Pleno do CNT certamente colocaria centenas de marítimos em posição de requerer sua reintegração ao Lloyd, com pagamento de vencimentos do período entre a dispensa e o retorno ao trabalho ${ }^{113}$. Não consta dos autos parecer, seja do Consultor Geral seja da Procuradoria, a respeito do recurso; mas há uma curta decisão do Ministro ("Mantenho a decisão do C.N.T.”, à fl. 70), seguida de uma notificação dirigida ao Lloyd informando a manutenção pelo Ministro, em 14 de janeiro de 1937, da decisão do Pleno do CNT e ordenando o cumprimento em dez dias.

Feita essa digressão, de modo a permitir a compreensão do contexto em que Benjamin Aprigio Pavão conseguira sua reintegração ao Lloyd Brasileiro, é tempo de voltar ao conflito institucional iniciado, que exigiu a mediação de Getúlio.

Após a expedição da carta de sentença chega aos autos carta remetida pelo Ministro de Viação e Obras Públicas a Vargas, em que este relata o caso de Pavão e pede a anulação do acórdão que beneficiara o reclamante, ao argumento de que ao Estado não se aplicariam as decisões do CNT. Vargas, em 23 de agosto de 1938, encaminha o documento "ao Ministro do Trabalho ${ }^{114}$ para informar"115.

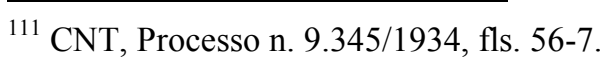

${ }^{112}$ Art. $5^{\circ}$ Das decisões proferidas pelo Conselho pleno caberá recurso para o Ministro do Trabalho, Industria e Commercio:

a) [omissis];

b) quando, allegando violação da lei applicavel ou modificação de jurisprudencia até então observada, que deverão ser citadas, o recorrente obtiver do Ministro a avocação do respectivo processo.

${ }^{113}$ A peça do Lloyd é explícita quanto às consequências da uniformização do entendimento do CNT: "A modificação da jurisprudência até então observada, traria, Exmo. Sr. Ministro, como é facil de calcular, graves damnos para a recorrente. No caso em apreço de Benjamin Aprigio Pavão em que, pela decisão é mandado reintegrar com todas as vantagens legaes, reclama o mesmo, de vencimentos atrasados perto de cem contos de réis!". CNT, Processo n. 9.345/1934, fl. 64.

114 "O Ministério do Trabalho, Indústria e Comércio foi criado ainda em 1930, menos de dois meses após a vitória da revolução. Embora abrangesse a indústria e o comércio, toda a sua energia era dirigida para a área do trabalho e da legislação social. O próprio ministro referia-se a ele com frequência simplesmente como 
A carta ${ }^{116}$ inicia expondo o conflito que já vinha se desenvolvendo desde 1926, à medida que foram se tornando mais recorrentes e efetivas as decisões do CNT contrárias às Estradas de Ferro e ao Lloyd Brasileiro, empresas sob controle do Estado e administração centralizada do Ministério de Viação e Obras Públicas:

"É mais um caso em que se patenteia flagrante desacôrdo de vistas entre os altos interesses da administração pública e deliberações daquele orgão de Justiça do Trabalho, com a missão precípua de julgar as questões pertinentes a empregados e empregadores.

(...)

Enquanto o derradeiro considerandum da deliberação faz uma referência à 'exoneração sem previo inquerito', as informações do Sr. Diretor do Lloyd Brasileiro afirmam ter sido satisfeita aquela formalidade, dando o depoimento de dois membros da respectiva comissão e declarando 'ter ficado apurada a falta grave'".

Prossegue o Ministro João de Mendonça Lima na defesa da limitação dos poderes do CNT quando o empregador é o Estado, de modo a impedir "indébita interferência" de um Ministério em outro:

"Creado o Conselho Nacional do Trabalho com a missão especifica de
julgar os dissidios entre empregados e empregadores, é de notar que vem
êle imprimindo às suas atividades uma extensão que não pode ter. É
assim que se faz confusão entre os superiores interesses do Estado e os
dos particulares, arrolando a União no grupo dos empregadores.
Razões fortes e elevadas, entre elas as de ordem, disciplina e defesa do
seu patrimonio moral e economico, colocam, entretanto, o Estado em
nivel superior, de geito que as questões com os seus servidores só podem
comportar dois juizos - o administrativo e o judiciário.
Outro fôro representaria indebita interferência destinada a quebrar o ritmo
das relações entre autoridades, com iguais responsabilidades e cada qual
com a sua esfera de ação delineada, limitada. É assim, que, o Ministério
do Trabalho, aprovando o acordam do seu Conselho, no caso presente e
em outros mais, passaria a interferir em todos os Ministérios,
estabelecendo uma posição incomoda para os seus titulares".

Propõe ainda os termos da limitação não apenas dos poderes do CNT, mas da ação da própria legislação trabalhista sobre os entes estatais:

Ministério do Trabalho e dizia ser ele por excelência o "Ministério da Revolução'." CARVALHO, José Murilo de. Cidadania do Brasil: o longo caminho. Rio de Janeiro: Civilização Brasileira, 2012, p. 112.

${ }^{115}$ CNT, Processo n. 12.908/1937, fl. 119.

${ }^{116}$ CNT, Processo n. 12.908/1937, fl. 119-22. 
"Da legislação social trabalhista deveriam ser aproveitados com referencia aos que direta ou indiretamente servem à União sómente os beneficios conferidos pelas suas Caixas de Pensões e Aposentadorias.

A parte relativa à disciplina e às demais relações desses servidores com $o$ Estado não deve ser retirada da competencia de cada Ministério, melhor habilitado para julgar a ação de seus serventuários."

Por fim, pede a anulação da decisão do Ministro do Trabalho, Indústria e Comércio no caso do marítimo Benjamin Aprigio Pavão:

"Em face do exposto, penso que o acordam do Consêlho Nacional do
Trabalho não pode ser considerado cousa soberanamente julgada quando
visa o Estado como empregador, esquece que se trata de pena aplicada
por deshonestidade e transforma a grave falta num premio correspondente
ao pagamento gracioso de 10 anos de vencimentos.
É uma decisão evidentemente injusta.
Diante do exposto, submetendo o caso à esclarecida deliberação de V.
Excia., cabe-me propor a anulação daquele acordam, atentatório dos
interesses da administração."

Antes do encaminhamento ao Ministro, emite a Procuradoria seu parecer ${ }^{117}$ :

"Cumpre-nos acentuar, quanto a esta alegação que si este Conselho não discutiu a questão de fáto - a invocada inidoneidade para o exercicio da função administrativa - não foi por culpa a ele imputavel, mas porque o Lloyd não atendeu a solicitações feitas por este Conselho para que remetesse o inquerito administrativo, que alegou haver feito (fls. 10), limitando-se a enviar copia do que constava do Livro Historico (fls. $11 \mathrm{e}$ 12).

(...)

Portanto, dada a inexistencia do inquerito, onde estivesse apurada regularmente a falta ou o fáto imputado ao reclamante, porque o Lloyd, embora solicitado, não o apresentou, o Conselho Nacional do Trabalho não 'fugiu ao sentido especifico', como afirma o titular do Ministerio da Viação, porque não havia fáto a considerar, mas uma questão de direito: saber se, em face dos expressos têrmos do art. 43 da Lei n. 5.109, embóra não regulamentada ao tempo da alegada falta, cabia ao reclamante, como funcionario do Lloyd, direito à estabilidade funcional.

(...)

Aliás, o proprio Ministro evidencia perfeito conhecimento dessa função legal do C.N.T. porque cita a propósito do v. acordão, contra o qual recorre para o Sr. Presidente da República, artigo e paragrafo do Dec. n. 24.784 de 14 de julho de 1934, que estabelecem, de modo inequivoco, a soberania de suas decisões passadas em julgado, tal como acontece, no caso presente, em que, máo grado a clareza solar da lei, S. Excia. interpõe um recurso extraordinario, pedindo àquela alta personalidade a anulação do v. acordão do C.N.T.

(...)

${ }^{117}$ CNT, Processo n. $12.908 / 1937$, p. 126-30. 
Cioso de suas prerrogativas, é verdade, mas adstrito apenas as que a lei lhe traçou, o Conselho Nacional do Trabalho tem pautado toda sua atuação de guarda vigilante e interprete fiel das leis do trabalho, dentro das fronteiras dessa mesma missão especifica.

(...)

A competencia do Conselho para conhecer desses casos está expressa nas leis (Lei n. 5.109, art. 43 [garantia de estabilidade decenal aos marítimos] e Dec. n. 20.465 de 1 de outubro de 1931 [garantia de estabilidade a empregados em empresas de transporte, de luz, força, telégrafos, telefones, portos, água, esgotos], art. 53, e Dec. n. 22.972 de 29 de junho de 1933, art. 89 [cria o IAP dos marítimos e repete a regra de estabilidade]).

Ademais, trata-se, na hipotese dos autos, de um dissidio entre uma empreza de navegação nacional - Lloyd Brasileiro - e um seu empregado

- Benjamin Aprigio Pavão -, sendo de notar que, ao tempo da reclamação - 30 de agosto de 1934 - como tambem ao tempo do julgamento pelo Conselho Pleno - 30 de junho de 1936 - aquela Companhia, embora fosse a União o seu maior acionista, era, então, uma sociedade anonima, como as outras.

Sómente ha pouco é que a citada Companhia ex-vi da Lei n. 420 de 10 de abril de 1937 passou a ser uma empreza oficial com o caráter de patrimonio nacional."

E resolve o Procurador Geral enfrentar a espinhosa discussão sobre a aplicação da legislação trabalhista e das decisões do CNT ao Estado. Recorre, ao final, sem maior cerimônia, ao mito da outorga da proteção trabalhista por Vargas:

\begin{abstract}
"Mas, admitindo, por via de argumentação, que ao tempo da reclamação e julgamento da especie, o Lloyd Brasileiro já fosse Patrimonio Nacional, ainda assim, não havendo o Decreto, que o encampou, o retirado da sanção das leis trabalhistas, nem lhe criado uma jurisdição especial para julgamento dos dissidios entre a Empreza e seus serventuarios, é obvio que não foi o Conselho Nacional do Trabalho que o arrolou, como empregador, mas a propria União que não o executou, por sabia politica, do ról dos demais empregadores sujeitos, igualmente, às numerosas leis que ela, desde 1930, sob a esclarecida visão de um véro e grande estadista - o Sr. Presdiente Getulio Vargas - vem ininterruptamente criando para defesa do trabalhador brasileiro."
\end{abstract}

Para combater o argumento de que os conflitos entre o Estado e seus servidores só poderiam ser tratados por esfera administrativa própria ou pelo Poder Judiciário, o Procurador cita julgados do Supremo Tribunal Federal que, segundo ele, determinam que “as decisões do C.N.T., passadas em julgado, em materia de dissidios entre empregadores e 
empregados, não podem mais sofrer re-exame pela justiça comum, só competindo a esta a sua execução."118

Em seguida, acolhendo os termos do parecer, o Ministro Waldemar Falcão responde ao Presidente da República, que então encaminha a questão para a análise do Consultor Geral da República, Orozimbo Nonato.

$\mathrm{O}$ parecer ${ }^{119}$ inicia afastando a necessidade de regulamentação do direito à estabilidade decenal dos marítimos previsto na Lei n. 5.109/1926. O consultor se apoia em citações de vários comentadores do Código Civil - Ferreira Coelho, Carvalho Santos e Eduardo Espínola - para, ao final, manifestar que o artigo 43, da Lei n. 5.109/26 “[E]nunciava um princípio auto-executável, estabelecendo uma garantia para o empregado que não poderia, no regulamento, ser alterada."

Orozimbo passa então a contrariar as razões trazidas na carta do Ministro de Viação e Obras Públicas a Vargas. Observa a ausência de provas da alegada inidoneidade de Benjamin Aprigio Pavão e entra na questão da competência do CNT "para decidir

${ }^{118}$ Os julgados citados são os Agravos de Petição n. 7.424, 7.179 e 8.045, e não tratam especificamente da eficácia das decisões do CNT; mas, considerando que decidem matérias incidentais a processos de execução em trâmite perante a Justiça Federal, e que não as trancam sob o argumento da carência de eficácia, é de se admitir que o STF vinha admitindo a execução das decisões do CNT sem a reabertura da discussão de mérito. A principal matéria dos julgados se refere à validade da penhora de receitas das empresas encampadas após a Revolução de 1930. As decisões negam essa possibilidade, mesmo que o exequente tenha sido empregado em período anterior à encampação, por se tratar de execução contra a Fazenda Pública, com rito e regras próprias. Há vários julgados do STF se pronunciando negativamente sobre a possibilidade de revisão judicial de decisões do CNT e do Ministro do Trabalho, Indústria e Comércio. Cf., por exemplo, Apelação Cível n. 7.928 - DF, Standard Oil Company of Brasil v. Arnaldo Alves Couto, relator Ministro Philadelpho Azevedo, julgado em 28 de janeiro de 1943. O voto do relator deixa entrever, em alguma medida, com que olhos o Poder Judiciário via a "questão social" bem como a atuação do CNT: "De início acentúo que consideraria bem dispensado o empregado, em face do que consta dos autos, do Parecer do Procurador e do próprio acórdão do Consêlho Nacional do Trabalho - bastariam indícios e presunções, confessa-se, e na hipótese havia mais do que isso - o que não se poderia exigir é que a Junta julgadora pensasse da mesma maneira que o encarregado do inquérito, pois do contrário seria mais fácil entregar a êste a decisão. (...) [A] verdade é que o preceito constitucional continha o mínimo de proteção, que a lei ordinária podia ultrapassar, como, aliás, veiu a fazer a carta de 1937, embora pessoalmente considére de suma inconveniencia a execução específica dessa obrigação de fazer [reintegrar o empregado], pois o devedor devia, nêsse terreno, ter sêmpre a faculdade de transformar a reintegração em sucedâneo pecuniário." O Ministro ainda rejeita a argumentação sobre a característica "híbrida" do regime de proteção trabalhista anterior à instituição da Justiça do Trabalho (conhecimento perante órgão administrativo e execução perante o Poder Judiciário): "De acôrdo com reiterados votos, já por mim proferidos, considero méramente administrativa a atividade daquêles órgãos mixtos, de natureza individual ou colegial; por isso, ainda mesmo na vigência do decreto-lei n. 39, sustentei a amplitude de defesa na execução das sentenças trabalhistas anteriores a 1940. Mas si, assim entendo, tenho tambem de, coerêntemente, afastar o rigor dos conceitos jurídicos, como são apreciados nos verdadeiros tribunais - não seria razoável considerar-se méras decisões administrativas, suscetíveis de anulação judicial, e observar a rigidez de coisa soberanamente julgada, como pretende a União Federal, ou apurar ao extremo régras de competência e de prazo, como por outro lado, sustenta a Standard Oil. No meio termo, como em tudo, estará a justiça. Assim, não póde prevalecer a verdadeira tortura de textos, a que se dedicou com extremo rigor lógico o douto patrono da Apelada, dissecando a técnica das leis trabalhistas; a norma não poderia, principalmente nêsse terreno ser interpretada com tal rigor gramatical, mas, antes, a buscar seu objetivo social." E a solução não escapou da invocação ao "razoável", ao "meio termo" e ao "objetivo social”, lugares comuns da aplicação da legislação trabalhista à época.

${ }^{119}$ CNT, Processo n. 12.908/1937, fls. 141-55. 
questões entre a União e seus servidores", abrindo longa digressão sobre a "natureza das autarquias". Segundo o consultor, o Lloyd só passou a autarquia - com "carater de empresa oficial" - com a edição da Lei n. 420, de 10 de abril de $1937^{120}$; antes era "uma sociedade anônima, que não perdia essa natureza pelo fato de ser a União sua maior acionista". Cita o institucionalista Maurice Hariou, o administrativista Tito Prates da Fonseca, o publicista espanhol José Gascón y Marin, o administrativista alemão Fritz Fleiner, o publicista francês Georges Renard e o jurista italiano Santi Romano; todos em abono da tese segundo a qual o Lloyd seria um ente paraestatal, com personalidade e patrimônio próprios, "selfgovernment" e "especialização orgânica”.

Todavia, a solução para o caso não poderia provir de outro instituto senão aquele mais em voga na época:

“[E]mbora se reconheça que sua atividade, auxiliar da do Estado, se
desenvolva fóra das normas da vida privada, como se exprime José
Gascón y Marin, parece-me que a situação do empregado de uma
entidade autárquica não é, linearmente, a de um funcionário do Estado.
(...)
A autarquia nem é Estado nem empresa particular.
Como, entretanto, repugna não se lhe dar um quadro de garantias e
direitos, a assimilação ao empregado de particular, em falta de lei
expressa, apresenta-se como imperativo de equidade.
O ‘Lloyd Brasileiro' é uma autarquia industrial.
O caso de seus empregados não oferece dificuldades, pois estão êles, por
disposição de lei, abrigados na proteção legislativa outorgada aos
empregados em atividades particulares.”

Invocado o argumento da equidade, avança Orozimbo Nonato para também estender a proteção a todos os empregados de empresas públicas:

"Ha, entretanto, a considerar-se a situação dos empregados de outras
entidades autárquicas.
Em conferências realizada em 25 de julho no Serviço de Estatística da
Previdência e do Trabalho, publicada no 'Jornal do Comércio' de 18 do

${ }^{120}$ Art. $1^{\circ}$ Fica o Poder Executivo autorizado a assumir a responsabilidade de todo o ativo e passivo da sociedade anônima Companhia de Navegação Lloyd Brasileiro, incorporando todo o seu acervo ao patrimônio da União.

Parágrafo único. Dentro de quinze dias da publicação desta lei serão convocados, em assembléia geral, os acionistas do Lloyd Brasileiro para discutir e resolver sôbre a proposta de encampação.

(...)

Art. $3^{\circ}$. Fica organizada a emprêsa de navegação denominada Llod Brasileiro, de propriedade da União, com a aquisição de todo o ativo da Companhia de Navegação Lloyd Brasileiro, na forma estabelecida no artigo anterior.

Art. $4^{\circ}$ A nova emprêsa terá inteira autonomia administrativa, será dirigida e administrada pela União, por intermédio de um diretor de livre nomeação e demissão do Presidente da República, ficando diretamente subordinada a Ministério de Estado da Viação e Obras Públicas. 
corrente mês, referia-se ao assunto o Senhor Oscar Saraiva, sublinhando que ainda não se traçou o estatuto dos servidores das autarquias.

E razão era que se lhes definissem os direitos e garantias, a par das obrigações de deveres, pois, em rigor, não lhes cabe, senão por inspirações da equidade, a proteção concedida ao empregado particular e, por outro lado, não lhes é extensivo o estatuto dos funcionários.

(...)

Enquanto, porém, êsse estatuto não se traça, a situação do empregado de entidade autárquica não poderá estar - seria inequitativo e contrário ao espirito de nossas instituições - ao desabrigo das leis de proteção ao trabalho."

Em 3 de setembro de 1940, onze dias após o parecer do consultor, Vargas põe fim ao conflito, acolhendo as conclusões de Orozimbo Nonato e mandando arquivar o expediente. Em seguida, o processo foi restituído ao CNT para o cumprimento definitivo da decisão do Ministro do Trabalho, Indústria e Comércio que, ao que tudo indica, foi bem sucedido, uma vez que o próprio reclamante peticiona nos autos pedindo de volta sua carteira profissional, antes do arquivamento definitivo, sem nada mais requerer ${ }^{121}$.

Esse conflito seria resolvido apenas com a edição do Decreto-lei n. 4.373, de 11 de junho de 1942, que acolhe a tese do Ministro de Viação e Obras Públicas veiculada no caso de Benjamin Aprigio Pavão ${ }^{122}$. A partir daí o CNT passaria rejeitar liminarmente as reclamações de empregados de empresas públicas. A força da regra atingiu até mesmo uma decisão passada em julgado emitida pelo Conselho Regional do Trabalho da $5^{\text {a }}$ Região (Bahia), que determinava a reintegração de Raul Antônio dos Santos pela Viação Férrea Leste Brasileiro. A determinação para o não cumprimento foi emitida pelo próprio Ministro de Viação e Obras Públicas após a edição do Decreto-lei n. 4.373/1942 ${ }^{123}$. Anos antes da edição do referido decreto-lei o Ministro de Viação já vinha expedindo “exposições de motivos”, direcionadas ao Presidente da República, a cada decisão desfavorável às empresas públicas emitidas pelo CNT e pela Justiça do Trabalho. As “exposições” reuniam argumentos para justificar o não cumprimento.

121 Em vários outros processos analisados aparecem reclamações de trabalhadores sobre a ausência do cumprimento ou atraso na efetivação da decisão do CNT por parte das empresas. O cumprimento é também noticiado em outros, com telegramas de agradecimento, acompanhados às vezes de pedidos de desentranhamento de documentos dos autos, como carteiras profissionais juntadas para a prova do tempo de serviço. Presume-se no caso em análise que houve cumprimento, pois o reclamante não noticia nenhuma irregularidade nos autos.

${ }^{122}$ Art. $1^{\circ}$ Aos empregados dos serviços da União Federal, das empresas por ela administradas e das que, de sua propriedade, são administradas pelos Estados, não se aplica a legislação de proteção ao trabalho.

Parágrafo único. A esses servidores, todavia, são assegurados os direitos que derivam da legislação de previdência social.

Art. $2^{\circ}$ As questões resultantes das relações de trabalho entre os empregados a que se refere o presente decreto-lei e as respectivas administrações serão dirimidas por via administrativa, com recurso para a Justiça Ordinária.

${ }^{123}$ CNT, Processo n. $1.434,1942$. 
Finda a queda de braço, Carmen Aurora da Conceição, postulando pelo reconhecimento do direito à reintegração (com necessária conversão em indenização) de seu falecido marido, o foguista da Estrada de Ferro Central do Brasil José Plácido da Silva, também não obteve sucesso ${ }^{124}$.

A retórica laudatória a Vargas e à revolução, e a repetição à exaustão do mito da outorga, eram comuns nos arrazoados submetidos ao CNT pelos trabalhadores. Domingos Benedetti enviou, no início de 1939, uma carta ao Presidente da República suplicando pela resolução de seu caso em face da Companhia de Comércio e Navegação, em trâmite perante o CNT desde 1936. A Secretaria da Presidência encaminhou a missiva ao CNT, contendo uma mistura de elogio e desilusão:

\begin{abstract}
"Exmo. Snr. Presidente,
Accentuou V. Excia. em seus discursos, repetidas vezes, que se acabaram os intermediarios entro o Governo e o povo. Fio-me nas palavras de V. Excia. para vos dirigir esta representação, certo de que presto um serviço ao Governo, pondo o eminente chefe da Nação inteirado do que ocorre no Ministerio do Trabalho, onde as protelações constantes e a lentidão das decisões levam ao desespero os que recorrem à sua ação para fazer valer os seus direitos.

Humilde trabalhador, pertencendo ha quasi vinte anos à classe dos maritimos, venho ha longo tempo tentando reivindicar direitos meus, juntamente com outros colegas igualmente prejudicados, e ainda não conseguimos, a despeito do longo tempo decorrido, obter decisão judicial sobre o caso.

A companhia contra a qual propuzemos ação, vem cansando aqueles que a acionaram excluindo-os das vantagens de gratificação anual e obtendo a desistencia de muitos, a troco de insignificantes quantias, em momentos de dramaticas necessidades para os mesmos. De cerca de duzentos reclamantes, são poucos hoje, - uns trinta mais ou menos, - os que prosseguem com a ação de tão lento curso. Esses mesmos cujos direitos em face da lei é liquido e certo, já se acham desiludidos das leis por V. Excia. instituidas, leis que são inegavelmente muito boas, mas que pouco ou nada servirão ao trabalhador brasileiro se não forem cumpridas e se acima delas se elevar o poder avassalante e corruptor das grandes empresas. Daí crear-se nos meios trabalhadores um ambiente de incerteza e desconfiança, de que se valem os inimigos do Governo, porque esse Governo timbra em contrariar o interesse particular em proveito do interesse geral, para formar ambiente de hostilidade e de agitação, tentando convencer aos trabalhadores que as leis sociaes são engodos e não realidades." 125
\end{abstract}

A tradução da questão social em termos jurídicos pelo emprego da equidade e de formas de interpretação alternativas à literalidade da lei aparece em situações as mais

\footnotetext{
${ }^{124}$ CNT, Processo n. 4.486/1942.

${ }^{125}$ CNT, Processo n. 2.705/1942, fl. 4.
} 
diversas. No caso do contrato de marchandage da Companhia Docas de Santos, havia uma discussão prejudicial ao mérito sobre a regra de prescrição aplicável aos trabalhadores reclamantes. Invocando textualmente a equidade, assim decidiu o Conselho:

"Diante de um grupo de reclamantes estáveis e não estáveis, devendo
aplicar a uma a prescrição anual e a outros a trintenária, a Câmara de
Justiça encontrou a solução de eqüidade, que o seu caráter de Justiça
tutelar aconselha, deixando de proclamar a prescrição quanto aos não
estáveis para não criar, assim, dentro do mesmo grupo de empregados
que reclamavam sob os mesmos fundamentos de direito, uma verdadeira
situação de injustiça.
E estava certa a decisão. Contrariá-la seria contrariar a Justiça social e a
grande base de humanidade que a reveste dentro do mundo moderno".

Em caso chegado à Câmara de Previdência Social, o relator Bello da Conceição votou pela concessão do seguro-velhice à recorrente septuagenária, que não teria recolhido a totalidade das contribuições ao Instituto de Aposentadoria e Pensões dos Comerciários. A argumentação novamente se apoia na invocação da equidade e procura afastar a interpretação gramatical ${ }^{126}$ :

\begin{abstract}
"Ora, pelos documentos de fôlhas 9 e 15 verificamos que a recorrente, velha, inválida e talvez doente, sem recursos, fêz de tudo ao seu alcance para vir a obter o benefício pleiteado, não n'o conseguindo.

São vicissitudes da vida face à rigidez da lei. Mas a lei previdencial não pode ser interpretada ao pé da letra, e sim segundo o espírito que a anima e vivifica.

(...)

Humanizar a lei não é violar os seus dispositivos nem mesmo desvirtuálos, é adaptá-la ou amoldá-la, antes de tudo, aos fatos sociais, à realidade das necessidades humanas.

Deixar a pobre velha de 72 anos de idade ao desamparo, quando se tem concedido aposentadoria a gente muito mais moça, é colocar a Previdência Social fora do seu pedestal, tirando-lhe a majestade e a fôrça. (...) O seguro-velhice, em certos e determinados casos, é um direito que, ultrapassando o próprio segurado, passa a pertencer a tôda a coletividade obreira, que na instituição para a qual contribuiu depositou as esperanças dos seus últimos dias.

(...) A eqüidade e os postulados básicos da Previdência Social dão à recorrente todo o direito à aposentadoria, sem prejuízo do recolhimento das contribuições devidas ao Instituto (...)".
\end{abstract}

\footnotetext{
${ }^{126}$ A curta ementa do acórdão é reveladora quanto às circunstâncias em que se recorria a topoi como a equidade e a interpretação teleológica: "SEGURO VELHICE - CONCESSÃO - Concessão de segurovelhice tendo em vista as circunstâncias especiais de que se reveste o caso". Mais adiante, no também curto relatório, já aparece um juízo preliminar de valor sobre a decisão anterior de não concessão do benefício: "A decisão recorrida baseou-se em rígida disposição de lei". Parece haver uma cisão na aplicação do "novo direito"; para os "casos comuns" a rigidez da lei, para os "casos especiais" a equidade e a interpretação em termos.
} 
O próprio Poder Executivo imbuiu-se da missão de apontar a "natureza social" da legislação trabalhista e até mesmo de improváveis dispositivos do Código Comercial e do Código Civil. O Ministro do Trabalho, Alexandre Marcondes Filho ${ }^{127}$, propôs ao Presidente Getúlio Vargas a "expedição de um decreto-lei de caráter interpretativo", diante de uma situação que envolvia temas de direito intertemporal e aplicação do direito comum a litígios sobre a relação de emprego.

Após a instalação da Justiça do Trabalho, esta passou a ser competente para a execução de seus próprios julgados. Contudo, o Regulamento da Justiça do Trabalho (artigo 224, do Decreto n. 6.597, de 13 de dezembro de 1940) previa que as execuções dos julgados das antigas Juntas e Comissões Mistas iniciados na justiça comum nela permaneceriam. Contudo, chegavam ao Ministro Marcondes Filho notícias de que os Tribunais de Apelação dos Estados e do Distrito Federal vinham anulando as decisões das Juntas que determinavam o pagamento de indenização "por rescisão abusiva e sem aviso prévio (...) além da indenização por antiguidade de que trata a Lei n. 62, de 5 de Junho de 1935”, "sob a alegação de que as normas referentes ao aviso prévio são as previstas nos arts. 81 e 1.221, dos Códigos Comercial e Civil, respectivamente"128.

Afirmavam os tribunais de apelação falecer competência aos tribunais do trabalho para a aplicação de disposições do direito comum, mesmo tendo o Supremo Tribunal Federal decidido que "é negado à Justiça Ordinária que se substitua aos tribunais trabalhistas na apreciação de qualquer aspecto da controvérsia que a estes tribunais

\footnotetext{
${ }^{127}$ Alexandre Marcondes Filho assumiu o Ministério após a saída do interino Dulphe Pinheiro Machado, que ocupou o cargo de junho a dezembro de 1941, após a saída de Waldemar Falcão. Marcondes Filho era um bem sucedido advogado falencista em São Paulo. Seu escritório era frequentado pela nata do empresariado paulistano bem como por Assis Chateaubriand, proprietário dos Diários Associados. Definitivamente, não era um homem da política, exceto pela aproximação com o perrepismo paulista nos anos 1920, ao lado de Menotti Del Picchia. Sua importância na política nacional cresceu quando passou a cumular o cargo de Ministro da Justiça, em julho de 1942. A situação foi essa até 1945. Sua relação de amizade com Roberto Simonsen asseguraria ao empresariado um fácil acesso ao Ministério, que também era da Indústria e do Comércio. Cf. GOMES, Angela de Castro. A invenção do trabalhismo. $3^{\mathrm{a}}$ ed. Rio de Janeiro: Editora FGV, 2005, pp. 184-5.

${ }^{128}$ CCom, art. 81. Não se achando acordado o prazo de ajuste celebrado entre o proponente e os seus propostos, qualquer dos contratantes poderá dá-lo por acabado, avisando o outro de sua resolução com um mês de antecedência. Os agentes despedidos terão direito aos salários correspondentes a este mês, mas o proponente não será obrigado a conservá-lo no seu serviço.

CC1916, art. 1.221. Não havendo prazo estipulado nem se podendo inferir da natureza do contrato, ou do costume do lugar, qualquer das partes, a seu arbítrio, mediante aviso prévio, póde rescindir o contrato.

Parágrafo único. Dar-se-á o aviso: I - com antecedência de oito dias se o salário se houver fixado por tempo de um mês ou mais; II - com antecipação de quatro dias, se o salário se tiver ajustado por semana ou quinzena; III - de véspera, quando se tenha contratado por menos de sete dias".
} 
privativamente compete nos termos de sua destinação constitucional" "129 Essas e outras experiências interpretativas seriam mais tarde incorporadas à Consolidação. No específico caso da aplicação do direito comum, a Consolidação trouxe nada menos do que três dispositivos (artigos $8^{\circ}, 769$ e $889^{130}$ ).

O Ministro Marcondes Filho entendia ser do Executivo, na pessoa do próprio Presidente da República, o grande garante da efetividade das normas de "natureza social", o papel político de vencer as resistências na aplicação da legislação trabalhista. No caso do decreto-lei interpretativo, adotou uma fórmula casuística, embora simples e direta, que continha a mensagem retórica do "novo direito":

\footnotetext{
"Artigo único. Os arts. 81 e 1.221, respectivamente, dos Códigos Comercial e Civil, constituem normas de natureza social, podendo ser aplicados pelos tribunais do trabalho, naquilo em que não estiverem revogados" $" 131$.
}

No desempenho desse papel, Marcondes Filho frequentemente vinha às revistas especializadas expor e comentar de forma didática os vários atos do Poder Executivo em matéria trabalhista. Quando da edição da Portaria Ministerial n. 790, que limitava a legitimidade para direcionar consultas ao Ministério do Trabalho aos "sindicatos legalmente reconhecidos" (excluindo a postulação de empregados e empregadores individualmente), Marcondes Filho expôs razões na Revista do Trabalho, explicando a necessidade de "disciplinação administrativa" e de colocar os sindicatos no exercício de “suas verdadeiras funções”. Não se limitou o ministro, porém, à exposição de motivos. Inseriu também no texto dura crítica "às exigências pecuniárias que fazem os

\footnotetext{
${ }^{129}$ Apud BRASIL. Exposição de Motivos do Sr. Ministro Marcondes Filho, Decreto-lei n. 4.037, de 19 de janeiro de 1942, STF, $1^{\text {a }}$ Turma, Acórdão 94.994 in Jornal do Comércio, de 15 de abril de 1941.

${ }_{130}$ Art. $8^{\circ}$. As autoridades administrativas e a Justiça do Trabalho, na falta de disposições legais ou contratuais, decidirão, conforme o caso, pela jurisprudência, por analogia, por eqüidade e outros princípios e normas gerais de direito, principalmente do direito do trabalho, e, ainda, de acordo com os usos e costumes, o direito comparado, mas sempre de maneira que nenhum interesse de classe ou particular prevaleça sobre o interesse público.

Parágrafo único - O direito comum será fonte subsidiária do direito do trabalho, naquilo em que não for incompatível com os princípios fundamentais deste.

Art. 769. Nos casos omissos, o direito processual comum será fonte subsidiária do direito processual do trabalho, exceto naquilo em que for incompatível com as normas deste Título.

Art. 889. Aos trâmites e incidentes do processo da execução são aplicáveis, naquilo em que não contravierem ao presente Título, os preceitos que regem o processo dos executivos fiscais para a cobrança judicial da dívida ativa da Fazenda Pública Federal.

${ }^{131}$ BRASIL, Exposição de Motivos do Sr. Ministro Marcondes Filho, Decreto-lei n. 4.037, de 19 de janeiro de 1942. Revista do Trabalho, ano X, n. 1, p. 6, janeiro de 1942.
} 
sindicatos"132, que seriam impeditivas à ampla filiação, tornando os sindicatos pouco representativos. Segundo a lógica do Ministro, a única via que o modelo de organização sindical abria para uma ampliação da legitimação da postulação administrativa era uma ampliação das bases de filiados aos sindicatos. Estes eram os interlocutores junto ao Poder Executivo por excelência; temia-se a reunião de massas fora dos sindicatos bem como a geração espontânea de líderes entre os trabalhadores.

Também já deixava entrever o Ministro que a estrutura do Poder Executivo não comportava a demanda crescente pela solução de conflitos nas relações de trabalho. Esse era um dos motivos que animaria a criação, tempos depois, de um tribunal de cúpula em matéria trabalhista, e a transferência definitiva da competência para conhecer de litígios trabalhistas para uma estrutura componente do Poder Judiciário.

A ideia de controle da massa trabalhadora por meio da garantia pelo Estado de direitos mínimos, agregada em sindicatos praticamente jungidos ao Poder Executivo, continuava a ser a base política a sustentar o "novo direito". Todavia, percebia o Ministro que esse controle poderia ser feito de forma mais descentralizada, fora da estrutura de cúpula do Poder Executivo. Vargas parece não ter se oposto à ideia e avalizou a criação do que viria a ser o Tribunal Superior do Trabalho.

Esperava também o Ministro que os sindicatos cumprissem a contento sua função de amortecimento dos conflitos individuais pela sua coletivização, para solução conjunta e harmoniosa. Mas não haveria coletivização sem prévia associação de um número relevante de trabalhadores aos sindicatos; por isso, a crítica aos montantes cobrados dos associados ${ }^{133}$.

O texto da Portaria n. 790 chamava os sindicatos à assunção das "funções delegadas do poder público", elevadas que foram "ao plano superior da colaboração direta

\footnotetext{
132 "Todavia, para que bem se realizasse o que pretende esse ato - e mais: para que, na verdade, pudessem os sindicatos constituir, pela expressão numérica de seus associados, uma realidade representativa - mister se faz que o Governo facilite, como até agora tem feito, a sindicalisação; isto é que seja permitido o ingresso nos quadros sindicais de todos aqueles, empregadores e empregados, que têm direito, e mesmo dever, a essa admissão. Para tanto, seria necessário atentar para as condições econômicas dos profissionais e para as exigências pecuniárias que fazem os sindicatos, com o estabelecimento de um limite máximo de contribuição mensal. Há sindicatos de empregados que cobram $10 \$ 000$ por mês, de seus associados isto é, mais de um dia de trabalho, dada a base do salário mínimo; outros cobram $3 \$ 000$, o que é mais razoavel. Igualmente, com relação aos sindicatos patronais: o Sindicato das Empresas Proprietárias de Jornais e Revistas desta capital, fixou a sua mensalidade em $300 \$ 000$, evidentemente exagerada, proibitiva até para os periódicos menos lucrativos enquanto o sindicato dos banqueiros cobra apenas $50 \$ 000$ mensais. Não seria, portanto pedir muito que se fixassem os limites de contribuição, de modo a permitir a todos o gozo e vantagem de serem sindicalizados, destruídos, destarte, os privilégios existentes em certas associações de classe”. O texto da Portaria n. 790 pode ser consultado na Revista do Trabalho, ano X, n. 1, p. 26, jan-1942.

${ }^{133}$ Posteriormente, com o advento da CLT, a contribuição dos associados se limitaria ao chamado imposto sindical, correspondente a um dia de salário do empregado por ano.
} 
com o Govêrno". A portaria determinava que os sindicatos deveriam organizar "serviços de informações e de assistência jurídica”, e por ser a organização sindical política de Estado, o sindicato era reconhecido como "essencial à ordem social vigente, como base da democracia econômica instaurada pelo Estado Nacional, cumprindo, consequentemente, ao poder público intensificar a vida e atividade normal dos sindicatos".

Mas o que seria apenas uma portaria de disciplina e organização da máquina burocrática, associada ao fortalecimento dos sindicatos, escondia uma medida de boicote aos sindicatos não alinhados às pretensões do governo à época. O Ministério do Trabalho conheceria apenas as consultas formuladas pelos "sindicatos legalmente reconhecidos", isto é, não estavam legitimados os sindicatos clandestinos ou as entidades cujas atividades tivessem sido encerradas por determinação do Poder Executivo.

As portarias, palestras e discursos do Ministro Marcondes Filho se prestavam a direcionar a aplicação e a interpretar o "novo direito", além de propagandear os feitos atribuídos a Vargas. Não lhe escapavam minudências tais como a extensão da permissão de funcionamento aos domingos e feriados dos hotéis e hospitais para as barbearias e cabeleireiros "que fazem parte integrante de hoteis, hospitais, assim como dos clubes fechados" $" 134$.

Mas ainda havia percalços. Se os trabalhadores levavam as decisões do CNT à execução perante a justiça comum, os empregadores também buscavam a anulação destas. A The Leopoldina Railway Company Limited, invocando a Lei de Organização da Justiça Federal (Lei n. 221, de 20 de novembro de 1894), pede a anulação da decisão do CNT (mantida pelo Ministro em sede de avocatória ${ }^{135}$ ) que resultou na reintegração do

\footnotetext{
${ }^{134}$ Portaria Ministerial n. 839, de 17 de julho de 1942, cujo texto consta da Revista do Trabalho, ano X, n. 3, ago-1942, p. 16.

${ }^{135}$ A avocatória ministerial vinha prevista no artigo $5^{\circ}$, alínea "b", do Decreto n. 24.784 , de 14 de julho de 1934. Art. $5^{\circ}$ Das decisões proferidas pelo Conselho pleno caberá recurso para o Ministro do Trabalho, Industria e Commercio:

a) quando a deliberação tiver sido adoptada pelo voto de desempate;

b) quando, allegando violação da lei applicavel ou modificação de jurisprudencia até então observada, que deverão ser citadas, o recorrente obtiver do Ministro a avocação do respectivo processo.

$\S 1^{\circ}$ Em qualquer das hypotheses deste artigo, o recurso para o Ministro do Trabalho, Industria e Commercio deverá ser interposto ou requerido dentro de sessenta dias, contados da data em que a decisão recorrivel for publicada no Diario Official, ou da em que houver o recorrente tido sciencia inequivoca da mesma decisão.

$\S 2^{\circ}$ Sempre que o Ministro do Trabalho, Industria e Commercio, em virtude de recurso previsto em lei, tiver de se manifestar sobre decisão do Conselho, o presidente deste, ao encaminhar o recurso, prestará os esclarecimentos que julgar necessarios para a sua conveniente apreciação.

$\S 3^{\circ}$ As decisões do Conselho pleno e das Camaras, de que não tiver havido o recurso que couber, ou que houverem sido confirmadas, tornar-se-ão cousa soberanamente julgada e obrigarão em todo o territorio da Republica, sendo executadas perante a sua justiça de $1^{\mathrm{a}}$ instancia, na conformidade das respectivas normas processuaes.
} 
empregado estável José Ignacio, passada no bojo do Processo n. 3.602/34. A petição inicial da ação movida pela Leopoldina consta do Processo n. 13.599/1939, o qual se presta apenas a conter a citação da União, nas pessoas do Ministro do Trabalho, Indústria e Comércio, do Presidente do CNT e das respectivas Procuradorias, não havendo informações adicionais a respeito do andamento da "acção summaria" de anulação. O reclamante, segundo relato da empregadora, "penetrou no carro de aves, onde arrombou um engradado, delle furtando duas gallinhas" ${ }^{\text {136 }}$, foi preso imediatamente e dispensado sem inquérito, por ser evidente a falta grave.

A Primeira Câmara do CNT decidiu pela reintegração do reclamante, pela ausência do prévio inquérito para a apuração da falta grave. Em sede de embargos, o Pleno do CNT afirma que José Ignacio não logrou comprovar o tempo de serviço superior a dez anos, uma vez que não bastavam as datas de admissão e demissão constantes de sua carteira de ferroviário, sendo imperiosa a demonstração de que no interregno houve a prestação de efetivos serviços. O reclamante pede a avocação do processo pelo Ministro, que ordena a reforma do acórdão para manter a reintegração do reclamante, nos termos do parecer do Procurador Geral, que defende a tese segundo a qual o artigo 53, do Decreto n. $20.465 / 1931^{137}$ não contém menção a serviços efetivos, constantes ou ininterruptos ${ }^{138}$.

Ao final, enquanto a Leopoldina agia pela anulação da decisão do Ministro ${ }^{139}$, o reclamante requeria a extração da carta de sentença para promover a execução também perante a Justiça Federal. Não há notícia nos autos sobre o resultado da execução bem como da anulação pretendida pela Leopoldina.

Anulações e ações ordinárias ${ }^{140}$ - movidas em sua maioria por empregadores, mas também por empregados, todas contestando decisões do CNT -, eram recorrentes, mas o próprio Supremo Tribunal Federal tratou de refrear as tentativas de revisão perante a Justiça Federal, principalmente as rediscussões de mérito em sede de execução. Ao mesmo

$\S 4^{\circ}$ As cartas de sentença serão extrahidas pela Secretaria do Conselho, com as peças indispensaveis, devidamente selladas e rubricadas, subscriptas pelo director geral e assignadas pelo presidente do Conselho, o relator e o procurador geral.

${ }^{136}$ CNT, Processo n. 3.602/1934, fl. 11.

${ }^{137}$ Art. 53. Após dez anos de serviço prestado à mesma empresa, os empregados a que se refere a presente lei só poderão ser demitidos em caso de falta grave, apurada em inquérito, feito pela administração da empresa, ouvido o acusado com a assistência do representante do sindicato da classe, cabendo recurso para o Conselho Nacional do Trabalho.

${ }^{138}$ Processo n. 3.602/1934, fl. 77.

${ }^{139}$ Nova ação de anulação movida pela Leopoldina aparece no Processo n. 12.828/1935, em que o CNT presta informações à Procuradoria da República, responsável pela defesa da União.

${ }^{140}$ Cf. CNT, Processo n. 3.083/1942, em que a Procuradoria da República pede informações e subsidios para a defesa da União em processo contendo "acção summaria" movida pela mineradora A. Thun \& Cia pleiteava a anulação de uma decisão do CNT que ordenava a reintegração de um empregado que supostamente ocupava cargo de confiança. 
tempo, após 1941, o CNT começava a ter que lidar com a recém-instalada Justiça do Trabalho. No processo n. 1.434/1942, a Câmara de Justiça do Trabalho do CNT, reformando decisão da extinta Terceira Câmara, validou a dispensa do empregado da Estrada de Ferro Sorocabana João Branco dos Santos. No acórdão, exarado em 17 de janeiro de 1944, a Câmara reafirma duas importantes regras aplicáveis aos casos que lhe eram submetidos. A primeira se continha nas instruções para o processamento de inquéritos para a apuração de falta grave que vinham sendo expedidas desde 1933 pelo $\mathrm{CNT}^{141}$. Dizia respeito ao prazo improrrogável de noventa dias para o término dos inquéritos, dada a má-fé, observada em vários processos, consistente em tramitar inquéritos administrativos por muitos meses e até anos, sempre em detrimento da estabilidade decenal ou de sua aquisição. A segunda consistia em regra processual de transição, presente no Decreto-lei n. 3.229/1941, aplicável aos processos iniciados perante o CNT. O citado decreto-lei dispunha sobre a competência para o julgamento de processos referentes a dissídios de trabalho e a questões de previdência social, pendentes de decisão ou de recurso, à data da instalação da Justiça do Trabalho ${ }^{142}$. O Ministério da Revolução ia se desincumbindo paulatinamente da função de julgar os conflitos nas relações de trabalho de forma centralizada. A essa altura às Juntas já eram submetidas reclamações sobre violações de uma série de direitos trabalhistas, e não mais apenas sobre a estabilidade decenal. Tratava-se de ampliação que a estrutura do CNT, tal como concebida à época, certamente não suportaria. Além disso, optou-se por uma estrutura especializada dentro do Poder Judiciário, sem a dualidade anterior entre órgão administrativo julgando o mérito e Justiça Federal competente para executar os julgados do CNT.

\footnotetext{
${ }^{141} \mathrm{O}$ CNT, baseado na experiência dos inquéritos que lhe eram submetidos, foi emitindo instruções sobre o seu processamento. Formalidades, prazos, obrigatoriedade de publicação de editais de chamamento em jornais de grande circulação em caso de abandono de emprego, dentre outros aspectos, eram regulados pelas instruções, frequentemente mencionadas nos acórdãos.

${ }^{142}$ Art. $1^{\circ}$ Os processos de reclamação, de inquérito administrativo e de outros dissídios do trabalho, pendentes de decisão, ou em que houver decisão recorrivel, à data da instalação da Justiça do Trabalho, serão julgados:

a) pelo Ministro do Trabalho, Indústria e Comércio, aqueles em que o recurso para essa autoridade tenha fundamento no decreto n. 24.784, de 14 de julho de 1934;

b) pela mesma autoridade, os pedidos de reconsideração das decisões que houver proferido em dissídios de trabalho;

c) pela Câmara de Justiça do Trabalho do Conselho Nacional do Trabalho, os processos em que seria competente o Conselho Pleno do atual Conselho.
} 
Em julho de 1945, às vésperas da criação do Tribunal Superior do Trabalho, o Conselho Nacional do Trabalho discutia a pertinência do contrato de marchandage ${ }^{143}$, no chamado caso dos ensacadores de café.

O caso dos ensacadores de café ${ }^{144}$ mostra como o CNT se portava diante do fenômeno do trabalho intermediado, sem relação de emprego com o tomador de serviços. Francisco Ribeiro e outros ensacadores de café ajuizaram reclamação trabalhista em face da Companhia Docas de Santos, pleiteando "reintegração e salários atrasados, uns, e indenização, os demais".

A própria Companhia Docas de Santos, por meio de seu preposto, afirmou que:

$[\mathrm{O}] \mathrm{s}$ reclamantes trabalhavam normalmente em armazenagem de café, nos armazéns n. 3, 4 e 5, de propriedade da reclamada, e que o trabalho era dirigido por um intermediário, sem contrato verbal ou escrito com a reclamada, que apenas o tolerava. Adiantou que o referido intermediário (Diedrichs), que já substituía outro anterior (Soares), teria sido afastado do serviço por ser alemão.

A descrição da situação de fato aponta para uma forma de exploração da mão de obra, em que um intermediário, embora não organizado ele mesmo na forma de empresa, arregimentava trabalhadores para uma concessionária de serviço público. A questão colocada em juízo pelos trabalhadores era a seguinte: diante da inadimplência, da insolvência ou do simples sumiço do alemão Diedrichs, quem seria o responsável pelo pagamento dos salários atrasados e das indenizações devidas aos ensacadores?

O juízo de direito (funcionando como juízo laboral) bem como o Conselho Regional consideraram que a Companhia Docas de Santos não sucedera Diedrichs, e que não era aquela responsável pela demissão dos ensacadores. Decidiram, ainda, declarar a prescrição relativamente às pretensões de alguns ensacadores não estáveis.

A Câmara de Justiça do Trabalho, à sua vez, considerou irrelevante a investigação da sucessão de empresas. Importante era a identificação de existência da marchandage $e^{145}$, como pedido pelos reclamantes. O voto do relator E. J. Cossermelli, sob a presidência de Oscar Saraiva, contém aguda crítica à marchandage:

${ }^{143}$ BRASIL, Jurisprudência: Conselho Nacional do Trabalho, v. XXVIII, Rio de Janeiro, Imprensa Nacional, 1946, pp. 15-18.

${ }_{144}^{145}$ CNT, Processo n. $7.103 / 44$.

145 "O sistema de contratar serviços chamado marchandage constitui uma espécie de Contrato de Empreitada. É um verdadeiro contrato de empreitada considerando-se a relação que liga o 'marchandeur', ao empreiteiro principal, e é contrato de marchandage quando são consideradas as relações existentes entre o marchandeur e os operários ou artífices que realizarão o serviço contratado. Caracteriza-se esse tipo de relações de trabalho pela presença de três partes contratantes: a) um empreiteiro principal, dono da obra; b) um sub-empreiteiro (o 
"E, se os autos não revelam sucessão de emprêsa, apresentam a existência clara do empreiteiro principal e do subempreiteiro, figuras essenciais para a caracterização da marchandage.

A marchandage sempre foi repudiada, no Brasil, pelos tribunais trabalhistas, como pelas decisões administrativas do Ministério do Trabalho.

$\mathrm{Na}$ falta de lei expressa que permitisse ligar o marchandeur ao empregador principal, o verdadeiro empregador, encarregou-se disto a jurisprudência firmando-se na doutrina estrangeira e na então incipiente doutrina nacional. Aqui, os chamados 'contratos de equipe' se apresentavam com mais freqüência e com todo o seu acervo de prejuízos e falsas garantias para o trabalhador (...).

Reconhecendo e proclamando a marchandage, a jurisprudência pôs fim à exploração, declarando que o empreiteiro principal era o verdadeiro empregador".

$\mathrm{Na}$ busca da realidade da execução dos contratos de trabalho, o relator

Cossermelli recorre ao instituto da delegação, para caracterizar a posição do alemão banido

Diedrichs:

"É ainda a reclamada que informa que Diedrichs não se achava constituído em emprêsa ou companhia (fôlhas 205). Isto quer dizer, apenas, que êle era, realmente, um delegado da Companhia Docas de Santos, a concessionária do serviço, aquela que, à primeira exigência das companhias de navegação suas clientes, substituiu êste delegado.

E só assim se pode entender a situação de Diedrichs, uma situação de delegado da reclamada, que não constituía emprêsa ou companhia, que era passível de demissão a qualquer momento, e de demissão imposta pela reclamada. (...)

Ora, quem detém, por lei, um serviço e o passa a outrem, realmente o está delegando, subempreitando-o, compondo, com tôdas as cores e em todos os detalhes, a figurada marchandage".

Insere, ainda, o relator no voto uma espécie de advertência, um obter dictum sobre as consequências da continuidade da adoção da marchandage pela Companhia Docas de Santos:

“O simples assentimento a que outrem execute êsses serviços, atribuídos por lei, seria uma prova cabal de irresponsabilidade, de desrespeito à palavra da lei delegadora, ao texto do contrato, irresponsabilidade

marchandeur); c) os operários ou artífices, que executarão a obra contratada. Os executores da obra, ou sejam, os operários, não contratam com o empreiteiro principal, mas com o marchandeur. Este é quem contrata com aquele. Esse contrato é também chamado, com vantagem, de contrato de sub-empreitada. Por isso mesmo nem todas as relações de trabalho o comportam". (PIMPÃO, Hirosê. Marchandage. Revista do Trabalho, ano X, n. 8, p. 10, ago-1942). 
impossível de ser imputada à Companhia Docas de Santos, das maiores e mais acreditadas emprêsas concessionárias do Brasil”.

Cita o relator um manual de Dorval Lacerda ( $\mathrm{O}$ contrato individual de trabalho), editado pela própria Editora Revista do Trabalho. Dorval Lacerda aparece citado como referência em diversos julgados das Juntas e Conselhos Regionais, e em artigos da época. Além de Dorval Lacerda, os julgadores citavam artigos e resenhas da Revista do Trabalho, também editada por Dorval Lacerda, Helvecio Xavier Lopes e Gilberto Flores. No CNT as citações aos doutrinadores especializados aparecem com recorrência muito menor.

O relator do caso dos ensacadores de café, Oscar Saraiva, era homem de confiança do Ministro Alexandre Marcondes Filho. Saraiva, que acumulava o cargo de Consultor Jurídico do Ministério do Trabalho ${ }^{146}$, também se via traído pelas próprias pretensões interventivas do corpo de legislação trabalhista da época. Foi instado a responder consulta na qual negou que o Estado, por intermédio do Ministério do Trabalho, Indústria e Comércio, tivesse poderes para autorizar aumentos de salários definitivos, em substituição à vontade dos contratantes, empregador e empregado.

A consulta se deu a propósito do Decreto-lei n. 3.813, de 10 de novembro de 1941, que concedia aos empregadores a curiosa faculdade de conceder aumentos salariais temporários, "considerados como abônos"147, que não se incorporavam aos salários em definitivo. Viu-se Saraiva obrigado a esclarecer aos interessados que o decreto-lei continha uma faculdade, sem que dela se pudesse depreender que os aumentos em caráter definitivo necessitassem de qualquer autorização ministerial, bem como que "[E]ssa faculdade não revogou a possibilidade do empregador de aumentar os salários de seus empregados, fazendo tal aumento com caráter definitivo" ${ }^{\text {"48 }}$. Seria a anotação na carteira de trabalho que distinguiria os dois tipos de aumentos. O patronato, a buscar formas de lidar de forma menos rigorosa com a legislação trabalhista, aferrava-se a interpretações restritivas das normas, muitas vezes cabendo aos consultores e procuradores desarmar tais tentativas. A essa altura os empregadores já bem compreendiam que as disputas em torno de direitos e condições de trabalho tinham por uma de suas arenas preferenciais a própria máquina de

\footnotetext{
146 Saraiva foi posteriormente indicado por Marcondes Filho para integrar a comissão de elaboração da Consolidação das Leis do Trabalho.

147 SARAIVA, Oscar. Parecer exarado no Processo Administrativo n. 5.612-94, Aumento de salário em caráter definitivo, em 08/12/1941. Revista do Trabalho, ano X, n. 1, p. 25, janeiro de 1942.

148 SARAIVA, Oscar. Parecer exarado no Processo Administrativo n. 5.612-94, Aumento de salário em caráter definitivo, em 08/12/1941. Revista do Trabalho, ano X, n. 1, p. 25, janeiro de 1942.
} 
proteção do Estado. Tratava-se de testar se eram de fato totalizantes as pretensões do sistema de proteção de direitos sociais criada no âmbito do Ministério do Trabalho, Indústria e Comércio.

A edição de janeiro de 1942 da Revista do Trabalho trouxe um artigo de Arnaldo Sussekind intitulado "Jurisdição e competência da Justiça do Trabalho", em que apontava os estritos limites da competência em razão da matéria da Justiça do Trabalho, pela "qualidade dos litigantes"149. Sussekind se refere aos Regulamentos da Justiça do Trabalho (Decretos n. 6.596 e 6.597 de 12 e 13 de dezembro de 1940) como "lei de organização judiciária do trabalho". Ainda não se fala em processo do trabalho ou direito processual do trabalho, embora as referências doutrinárias citadas por Sussekind sejam de processualistas como João Mendes de Almeida Junior ${ }^{150}$ e Paula Batista ${ }^{151}$. Os primeiros manuais de processo do trabalho intitulavam-se muitas vezes apenas "Justiça do Trabalho" ou alguma variação em torno da expressão ${ }^{152}$. Esse é mais um indício de que havia uma vontade de fazer do direito do trabalho algo "novo", desvinculado da sistemática tradicional de outros ramos já largamente consolidados.

De fato, trata-se de mais um artigo de caráter didático sobre as bases do "novo direito". A aplicação e a interpretação do "novo direito", contudo, ainda se entrechocam com concepções jurídico-culturais arraigadas à época. Ao tratar da diferença entre a "pessôa do patrão" ("seria, aí, então, a de um intermediário entre o empregado e a emprêsa de que é chefe") e o empregador ("universalidade de bens, coisas e pessôas que são a emprêsa, na qual o patrão, o chefe respectivo, é um dos elementos, mas não integralmente a emprêsa"), Sussekind faz referência à disposição da Constituição de 1937, segundo a qual "nas emprêsas de trabalho contínuo, a mudança de proprietário não rescinde os contratos de trabalho, conservando os empregados para com o novo empregador, os direitos que tinham em relação ao antigo"153. Alerta o autor que até mesmo a morte do

\footnotetext{
149 "Hão de ser eles sempre e em todos os casos, empregadores e empregados, uns de um lado e outros do outro". SUSSEKIND, Arnaldo. Jurisdição e competência da Justiça do Trabalho. Revista do Trabalho, ano X, n. 1, p. 3, janeiro de 1942. Esta limitação da competência da Justiça do Trabalho à relação de emprego durou até a Emenda Constitucional n. 45/2004, embora a jurisprudência já admitisse algumas exceções anteriormente.

${ }^{150}$ Direito Judiciário Brasileiro. Rio de Janeiro: Freitas Bastos, 1940.

${ }^{151}$ BATISTA, Francisco de Paula. Compendio de theoria e pratica do processo civil comparado com o commercial e de hermeneutica juridica: para uso das faculdades de direito do Brazil. Paris: Garnier, 1901.

${ }^{152}$ Cf. CASTRO, Raimundo de Araujo. Justiça do Trabalho. Rio de janeiro: Freitas Bastos, 1941. Cf. também FERREIRA, Waldemar. Principios de legislação social e direito judiciario do trabalho. Rio de Janeiro: Freitas Bastos, 1939; e SUSSEKIND, Arnaldo. Manual da Justiça do Trabalho. Rio de Janeiro: Freitas Bastos, 1944.

${ }^{153}$ Alínea "g", do art. 137, da Constituição de 10 de novembro de 1937.
} 
empregador não tem o condão de resolver ou extinguir os contratos de trabalho ${ }^{154}$. Trata-se de uma tentativa de sistematização acerca da distribuição dos riscos do negócio, que não poderiam recair sobre o trabalhador.

Contudo, Sussekind apressa-se em afirmar que não se trata de uma regra de caráter absoluto, pois "nas emprêsas que têm um caráter particular intimamente ligado à pessôa do seu fundador, do seu chefe, como por exemplo, os escritórios de profissionais liberais, ou quando a morte do empregador acarretar fatalmente o fechamento da emprêsa" 155 , haverá justo motivo na cessação do contrato de trabalho. Nos primórdios do "novo direito" ainda eram comuns algumas interpretações de caráter restritivo dos textos normativos ou até mesmo o recurso ao "velho direito", como já visto em diversos julgados do CNT; por isso Sussekind admitia exceção à indenização do trabalhador mesmo que ela não decorresse diretamente do texto legal. A equidade agia sub-repticiamente também para limitar o alcance de certos direitos do empregado.

O mesmo se verifica em relação ao conceito de subordinação. Sussekind, ao comentar o artigo $1^{\circ}$, parágrafo único, da Lei n. 62, de 05 de junho de 1935, afirmava que “a lei não admite distinções relativamente à espécie de emprêgo ou à condição do trabalhador, nem entre o trabalho manual, intelectual ou técnico, e os profissionais respectivos". Mais adiante revela que "[O] conceito de subordinação, contudo, varia de acôrdo com a natureza do serviço prestado e a condição do profissional que o presta. De fato a subordinação deve ser entendida em termos, posto que não se póde exigir do médico, do advogado, do professor, etc., a mesma subordinação ao empregador que aquele que se verifica em relação ao trabalhador braçal" ${ }^{\prime 156}$. Nesse sentido, a situação jurídica dos empregados das "instituições pias, beneficentes e culturais" também desafiou as Juntas. A literatura e as decisões dos tribunais à época não encontravam maiores obstáculos na caracterização da empresa e na identificação do empregado como um prestador de serviço a ela ligado, e não à "pessôa do patrão". A ideia de ausência de lucro e de beneficência, no entanto, permitiu à Sexta Junta de Conciliação e Julgamento do Distrito Federal afastar a aplicação da Lei n. 62/1935 (conhecida como Lei da Despedida Injusta) a estas

\footnotetext{
${ }^{154}$ Lembre-se de que no caso dos ensacadores de café, a atividade do intermediador de mão-de-obra Diedrichs foi tratado como "emprêsa".

${ }^{155}$ SUSSEKIND, Arnaldo. Jurisdição e competência da Justiça do Trabalho. Revista do Trabalho, ano X, n. 1, p. 4, janeiro de 1942.

${ }^{156}$ SUSSEKIND, Arnaldo. Jurisdição e competência da Justiça do Trabalho. Revista do Trabalho, ano X, n. 1, p. 4, janeiro de 1942.
} 
instituições, que não estariam obrigadas a indenizar o trabalhador pela não concessão do aviso prévio ${ }^{157}$.

O “entendimento em termos" dos dispositivos da legislação trabalhista é um recurso constante, que ora conflita ora abranda os rigores da nova diretriz interpretativa, textualmente trazida na Lei de Introdução ao Código Civil ${ }^{158}$. O “entendimento em termos" também era outro dos mantras do "novo direito".

Por outro lado, em outras passagens, percebe-se que o esforço interpretativo advém da busca de uma definição estrita e fechada do que sejam as relações entre empregador e empregado. Sussekind exemplifica com um caso para o qual seria incompetente a Justiça do Trabalho, qual seja, a discussão entre empregador que aluga imóvel a um seu empregado ${ }^{159}$, olvidando-se de que a locação de imóvel residencial, nas mais das vezes, nada mais era do que pacto acessório e componente do contrato de trabalho.

A retórica do "novo direito" também encontrava espaço de difusão nas revistas jurídicas especializadas ${ }^{160}$ e seus principais formuladores e divulgadores eram os ministros de Vargas e os juslaboralistas da época. Alguns deles participariam mais tarde da edição da Consolidação. Era o caso de Arnaldo Sussekind que, acumulando o cargo de Procurador da Justiça do Trabalho com a função de Assistente Técnico do Ministro do Trabalho, fez publicar, em janeiro de 1942, na Revista do Trabalho, texto de palestra proferida no Instituto Nacional de Ciência Política. Nela criticava o individualismo liberal do século de XIX, o ideal de igualdade formal, "o poder econômico que vicia a manifestação dos mais fracos" e proclamava que a solução para a "questão social" estava na "intervenção do Estado" ${ }^{161}$. Não faltavam também laudas a Vargas ${ }^{162}$.

\footnotetext{
${ }^{157}$ Eis a ementa do julgado: "As instituições de caridade (no caso Hospício Nossa Senhora da Saúde), as puramente culturais, científicas, etc., cujo fim é exclusivamente o bem comum ideal, não estão sujeitas às sanções da Lei 62, de 5 de junho de 1935" (6 Junta de Conciliação e Julgamento do Distrito Federal, Processo 518-42, cuja íntegra consta da Revista do Trabalho, ano X, n. 17, ago-1942, p. 17.

${ }^{158}$ Sobre as relações entre a questão social, a legislação trabalhista e a Lei de Introdução ao Código Civil, cf. NETO, Paulo Macedo Garcia. A questão social na Era Vargas entre a regulação de trabalho da CLT e os "fins sociais" da Lei de Introdução ao Código Civil. In: MOTTA, Carlos Guilherme; SALINAS, Natasha Schmitt Caccia (org.). Os juristas na formação do Estado-nação brasileiro: 1930 - dias atuais. São Paulo: Saraiva, 2010, p. 223-51.

${ }^{159}$ SUSSEKIND, Arnaldo. Jurisdição e competência da Justiça do Trabalho. Revista do Trabalho, ano X, n. 1 , p. 4, janeiro de 1942.

${ }^{160}$ Revista do Trabalho e Revista da Indústria. Esta última editada pela Federação das Indústrias do Estado de São Paulo.

161 "O equilíbrio social não poderia viver sem a intervenção do Estado, feita no sentido de harmonizar as classes produtoras e trabalhadoras e tendo como escudo a Justiça Social. Nem se diga que os alicerces lançados constituíam meras promessas de um candidato à Presidência da República. Com efeito, vencida a revolução a 24 de Outubro de 1930, foi criado, a 26 de Novembro do mesmo ano, o Ministério do Trabalho. E não tardou a aparecer uma notável legislação que compensa a desigualdade econômica e reprime o abuso
} 
Joaquim Pimenta, Professor Catedrático de Direito da Universidade do Brasil, em prefácio ao "Manual da Justiça do Trabalho" do jovem procurador Arnaldo Sussekind, proclamava o direito do trabalho um ramo distinto dos demais, por sua flexibilidade:

"[T]alvez nesse campo, todo ele então por desbravar, é que seria possível
comunicar à obra em construção essa plasticidade, esse ritmo, essa
configuração que o tornou inconfundível e liberta da rigidez dogmática
que sempre acaba por deter na róchea inflexibilidade dos textos o
dinamismo perene da vida e do direito que o reflete"163.

Compunha também a retórica do "novo direito" uma ode constante à Encíclica Rerum Novarum e ao seu autor, o Papa Leão XIII. Os anais do I Congresso de Direito Social, organizado por Cesarino Junior, então professor da cadeira de Direito Social da Faculdade de Direito do Largo São Francisco, revelam a dedicação dos juristas ao estudo, à compreensão e à divulgação da encíclica. Novos bacharéis eram convocados a apresentar "teses" sobre a "influência da Rerum Novarum". Membros do clero eram chamados a presidir ou integrar mesas de discussão sobre o tema. Professores consagrados se dedicavam a esmiuçar os "remédios"164 para a questão social trazidos na Rerum Novarum $^{165}$. A incorporação da doutrina social da igreja contribuiu para a legitimação do "novo direito", e a moderação do discurso nela contido em muito contribuiu para a justificação dos controles e limites criados no âmbito do próprio sistema de proteção a direitos sociais.

da liberdade. Democratizou-se, pois, o Direito, por isto que sua sombra passou a acolher toda a Nação com uma proteção jurídica que o Direito individualista tolhia". Cf. SUSSEKIND, Arnaldo. Presidente Getúlio Vargas e o Direito Brasileiro do Trabalho. Revista do Trabalho, ano X, n. 1, p. 11, jan-1942.

162 "Desta fórma, graças à antevisão magistral de Getúlio Vargas, nasceu o Direito Brasileiro do Trabalho, sem que houvesse o desequilíbrio econômico, social e político causado pela luta de classes. Contudo, o pai do Direito Brasileiro do Trabalho não deu ao Brasil apenas uma legislação que é, sem favor, uma das mais completas e perfeitas de quantas existem. (...) Adaptando as noções de sindicalismo às realidades brasileiras, Getúlio Vargas fez com que os nossos Sindicatos jamais constituissem em instrumento de agitação e de luta de classes". Cf. SUSSEKIND, Arnaldo. Presidente Getúlio Vargas e o Direito Brasileiro do Trabalho. Revista do Trabalho, ano X, n. 1, pp. 11-2, jan-1942.

${ }^{163}$ O prefácio está reproduzido na Revista do Trabalho, ano X, n. 2, fev-1942, p. 4. Na verdade, a reprodução do prefácio está inserida em peça publicitária da editora Revista do Trabalho sobre o livro de Sussekind.

${ }^{164}$ A expressão é empregada pelo Professor Anacleto de Oliveira Faria: "Leão XIII, na Rerum Novarum, prescrevia três remédios para a Questão Social: a ação dos próprios interessados, unidos em associações profissionais; a intervenção do Estado; e a volta aos princípios e instituições cristão. Três remédios que deveriam ser usados de maneira concomitante." Cf. Democracia humana. Rio de Janeiro: José Olympio, 1958, pp. 144-5. No livro, de 1958, há um texto intitulado "Pratiquemos a Rerum Novarum" em que empreende uma reflexão sobre o esquecimento das diretrizes da encíclica por patrões e empregados.

${ }_{165}$ Anais do I Congresso de Direito Social, organizado pelo Professor Cesarino Junior. Anais compilados pela Biblioteca Central da Faculdade de Direito da USP. 
Havia um tripé doutrinário, repetido à exaustão nos primórdios do "novo direito" - o papel de Vargas, a influência da Encíclica Rerum Novarum e a reação ao "liberalismo" da Constituição de 1891.

Os registros de julgados não se resumem apenas ao Conselho Nacional do Trabalho. Nas Juntas de Conciliação e Julgamento do Distrito Federal aparecem as primeiras discussões sobre a caracterização do empregador. A Primeira Junta de Conciliação e Julgamento viu-se diante de demanda em que se questionava se o "chefe de orquestra" ${ }^{\# 166}$, responsável pelos pagamentos dos músicos, assumia ou não a característica de empregador. Igualmente, discutia-se a condição de empregador do condomínio perante o "encarregado de edifício" 167.

Já a Terceira Junta foi defrontada com o problema da extinção da empresa e os motivos que levaram ao seu encerramento. Qual a consequência para os "salários e percentagens" 168 ?

A tentativa de reduzir empregado a uma condição menos favorável do que a relação de emprego foi levada à Quinta Junta, por meio de caso em que uma empresa pretendia o reconhecimento da condição de "biscateiro" de empregado "com carteira anotada pelo Ministério do Trabalho ${ }^{169}$ ".

Os temas da sucessão de empresas e da estabilidade diante da extinção da empresa chegaram à Sexta Junta ${ }^{170}$. Também na Sexta Junta aparecia o tema da disciplina, como obrigação inerente à subordinação que nasce do contrato de trabalho. O tema ainda era visto na perspectiva das relações pessoais entre trabalhador e empregador, chegando os julgados a mencionar expressões como "respeito recíproco",171.

O confronto entre forma e realidade desafiava a homogeneidade dos entendimentos das Juntas de Conciliação e Julgamento. A Primeira Junta considerou válida a transação extrajudicial entabulada por empregado estável e empregador pela qual aquele

\footnotetext{
166 BRASIL, Jurisprudência: Conselho Nacional do Trabalho, v. XXVIII, Rio de Janeiro, Imprensa Nacional, 1946, pp. 72 e ss.

167 BRASIL, Jurisprudência: Conselho Nacional do Trabalho, v. XXVIII, Rio de Janeiro, Imprensa Nacional, 1946, pp. 69 e ss.

168 BRASIL, Jurisprudência: Conselho Nacional do Trabalho, v. XXVIII, Rio de Janeiro, Imprensa Nacional, 1946, pp. 75 e ss.

169 BRASIL, Jurisprudência: Conselho Nacional do Trabalho, v. XXVIII, Rio de Janeiro, Imprensa Nacional, 1946, pp. 84 e ss.

170 BRASIL, Jurisprudência: Conselho Nacional do Trabalho, v. XXVIII, Rio de Janeiro, Imprensa Nacional, 1946, pp. 95 e 102.

171 BRASIL, Jurisprudência: Conselho Nacional do Trabalho, v. XXVIII, Rio de Janeiro, Imprensa Nacional, 1946, pp. 97 e ss.
} 
concordava em receber $50 \%$ da indenização a que teria direito, por ter "passado recibo de quitação" a este ${ }^{172}$.

Já a Terceira Junta, sobre o mesmo tema, afirmou que:

\begin{abstract}
"[E]xtinguindo a emprêsa, sem que ocorra motivo de força maior, como o conceitua a Consolidação das Leis do Trabalho, é devida a indenização paga em dôbro. O recibo de quitação impôsto pela emprêsa, na suposição de que está cumprindo a lei, não a isenta de completar o quantum a que efetivamente fêz jus o empregado, quando o direito à indenização em dôbro já lhe foi reconhecido pelos tribunais do trabalho ao julgarem casos idênticos" ${ }^{\text {173 }}$.
\end{abstract}

A insuficiência formal de documento apresentado pelo trabalhador foi-lhe também oposta pela Sexta Junta, ao decidir caso sobre transação do prazo para aquisição do direito à estabilidade:

\begin{abstract}
"Validade, em tese, do acordo no sentido de encurtar o prazo para aquisição de estabilidade. Tratando-se, porém, de sociedade anônima, administrada em conjunto por dois Diretores, a carta, firmada apenas por um dêles, assegurando ao empregado a estabilidade antes de decorrido o lapso de tempo previsto em lei, não pode obrigar a empregadora, não só por não estar devidamente assinada, como ainda em face do art. 119 do Decreto-lei n. 2.627, de 1940 ${ }^{174,}$.
\end{abstract}

Os artistas de cassino, de acordo com o Conselho Nacional do Trabalho, eram segurados obrigatórios do Instituto de Aposentadorias e Pensões dos Comerciários ${ }^{175}$.

O Conselho Nacional do Trabalho foi instado a se manifestar sobre a situação dos reservistas após a cessação do estado de guerra perante seus empregadores. Decidiu que as disposições da CLT se lhes aplicavam imediatamente ${ }^{176}$. O direito do trabalho foi usado como forma de incentivo à integração rápida e discreta dos soldados que retornavam das frentes européias, por meio da vedação da extinção dos contratos de trabalho nos

172 "INDENIZAÇÃO. Não tem direito a indenização o trabalhador estável que acordou legalmente em retirarse espontâneamente do serviço mediante o pagamento de $50 \%$ do que lhe era devido, tendo passado o respectivo recibo de quitação”. BRASIL. Jurisprudência: Conselho Nacional do Trabalho, v. XXVIII, Rio de Janeiro, Imprensa Nacional, 1946, pp. 28 e ss.

173 BRASIL, Jurisprudência: Conselho Nacional do Trabalho, v. XXVIII, Rio de Janeiro, Imprensa Nacional, 1946, pp. 72 e ss.

174 Art. 119. Os diretores não poderão praticar atos de liberalidade à custa da sociedade. Não lhes será, igualmente, lícito hipotecar, empenhar ou alienar bens sociais, sem expressa autorização dos estatutos ou da assembléia geral, salvo se esses atos ou operações constituírem objeto da sociedade. Decreto-lei n. 2.617, de 26 de setembro de 1940. Este dispositivo veio a ser revogado apenas pela Lei n. 6.404/76.

175 BRASIL, Jurisprudência: Conselho Nacional do Trabalho, v. XXVIII, Rio de Janeiro, Imprensa Nacional, 1946, pp. 45 e ss.

176 BRASIL, Jurisprudência: Conselho Nacional do Trabalho, v. XXVIII, Rio de Janeiro, Imprensa Nacional, 1946, pp. 29 e ss. 
períodos em que estivessem convocados. A aplicação imediata da legislação trabalhista aos veteranos também visava a impedir a criação de situações de discriminação e tratamento diferenciado.

Havia, ainda, a situação das "emprêsas liquidadas pelo govêrno"177. Não suficiente a sanção de liquidação liminar e compulsória, ficava a empresa sujeita a reclamações trabalhistas em foros distintos daqueles da execução dos contratos de trabalho, em claro uso da nova legislação trabalhista como forma de sanção dirigida aos que desagradavam o Estado Novo.

O direito do trabalho não passou incólume pela exceção invocada durante a Segunda Guerra Mundial. Houve uma legislação de emergência, que foi aplicada sem maiores ressalvas pelos juízes de direito e pelo próprio Conselho Nacional do Trabalho.

A juíza de direito da comarca de Pelotas - RS, Alsina Lemos, indeferiu o pleito de reintegração formulado por diversos "súditos do Eixo", trabalhadores de origem alemã e italiana da The Rio Grandense Light \& Power Synd., Ltd.. Tratava-se de empregados estáveis, que foram dispensados com justa causa, lastreada em "fôrça maior". A sentença adota a forma dos consideranda:

"[C]onsiderando que a Alemanha e Itália, nações integradoras do pacto de guerra denominado 'Eixo', têm distinguido a sua ação dissolvente, perversa, deletéria, de destruição, de morte, sem qualquer escrúpulo, nem atenção de quaisquer imperativas de ordem moral, pois que os de ordem jurídica, há muito, já haviam relegado, como carga inútil;

considerando que aqueles dois países subverteram, dessa forma, todas as normas de moralidade que costumam presidir as relações lícitas e normais entre os homens, implantando entre as nações e os povos a surpresa, a desorientação, a insegurança, o esfacelamento, a carnificina e o horror, pela utilização de métodos de uma barbaria requintada aos extremos de uma ferocidade satânica;

considerando que essas mesmas nações, como instrumento de eleição e dócil aos seus manejos, de uma docilidade de autômatos e de escravos, têm se utilizado, precisamente, dêsses tais inofensivos, pacíficos, tidos como integrados na sociedade e nos costumes dos países em que vivem, elementos que penetram nos lares, que trabalham no comércio, nas indústrias, nas emprêsas de utilidade pública, imiscuindo-se em todos os recônditos escaninhos da vida íntima da terra que lhes dá o pão, para, no momento propício, golpeando-a pelas costas, a envolverem no sangue e no desespêro, e, até, no opróbrio de si mesmas;

considerando que o ambiente que lhes facilita essa ação criminosa é a da boa fé, o da desprevenção do espírito e da ação do meio em que labutam; (...)

177 BRASIL, Jurisprudência: Conselho Nacional do Trabalho, v. XXVIII, Rio de Janeiro, Imprensa Nacional, 1946, pp. 81 e ss. 
considerando que essa ação advindo dêsse elemento alienígena é tão regularmente sistemática que, a não ser por insensatez, ou indefensável e condenável ignorância, para todo brasileiro, ser alemão ou italiano ao mesmo deverá corresponder, que a um elemento suspeito, perigoso, indesejável e hostil, até prova em contrário;

(...) considerando o mais que dos autos consta, julgo improcedente a reclamação feita e condeno os reclamantes nas custas e demais pronunciações de direito" ${ }^{\text {"178 }}$.

Em 31 de agosto de 1942, Vargas editaria o Decreto-lei n. 4.638, conferindo fundamento jurídico ao temor relatado na sentença da juíza de direito de Pelotas. O decreto-lei facultava a "rescisão de contrato de trabalho com súditos das nações com as quais o Brasil rompeu relações diplomáticas ou se encontra em estado de beligerância”.

A dispensa sem justa causa deveria ser precedida de autorização do Ministério do Trabalho, Indústria e Comércio, "sendo lícita, desde logo, a suspensão do empregado" (artigo $1^{\mathrm{o}}$, caput). O requerimento deveria necessariamente apontar a nacionalidade do empregado cuja dispensa era pretendida pela empresa, bem como os dados de seus dependentes.

A esses empregados deveria ser paga "uma indenização correspondente a meio mês de salário por ano de serviço ou fração superior a seis meses”, limitado o salário ao teto de "dois contos de réis". A indenização seria paga em parcelas mensais, tantas quantas correspondessem ao número de anos de trabalho do empregado. Aos empregados que praticassem "ato contrário ao bom andamento do serviço, da produção ou à segurança nacional" seria aplicada a dispensa por justa causa, com perda dos direitos inerentes à estabilidade, se existente. O decreto-lei obrigava a contratação de um empregado brasileiro para cada empregado "súdito do Eixo" dispensado.

No mesmo dia 31 de agosto de 1942, Vargas autorizou a "prorrogação da duração normal do trabalho nas empresas que interessem à produção e à defesa nacional", por meio do Decreto-lei n. 4.639. As jornadas de trabalho poderiam ser estendidas até a décima hora, mediante autorização do Ministério do Trabalho, Indústria e Comércio, sendo devido adicional de $20 \%$ (vinte por cento) para as horas excedentes à oitava.

Contudo, o próprio decreto-lei permitia fosse extrapolada a jornada de dez horas para a conclusão de "serviços inadiáveis" e até mesmo a realização de "trabalho contínuo", com "descanso semanal mediante escala de revezamento", nas "emprêsas de serviço público ou que interessem à produção e à defesa nacional”.

\footnotetext{
${ }^{178}$ Julgado sem número, publicado em audiência em 10/07/1942.
} 
A legislação trabalhista de exceção de Vargas, no período da Segunda Guerra Mundial, prestou-se a apoiar a produção de gêneros diversos e de material bélico para exportação aos países conflagrados. Ao mesmo tempo, era preciso mostrar em todos os campos a posição oficial de não apoiar Itália e Alemanha. Expressões como "fôrça maior" e "bem comum" aparecem com frequência. A condenação prévia e abstrata dos "súditos do Eixo" aparecia com clareza na "legislação de emergência".

A tese do "interesse da coletividade" aparece, ainda, em diversos julgados sobre dissídios coletivos. Pela teoria, o Estado extraía sua legitimidade para intervir nas negociações coletivas da necessidade de se evitar que "interesses de classe" se sobrepujassem aos "interesses da coletividade" $"$.

Fica claro que nem tudo eram flores no universo do "novo direito". Seu discurso próprio e seus fundamentos eram constantemente desafiados pela realidade das relações de trabalho e pelas oscilações da economia. O Procurador do Conselho Regional do Trabalho da Bahia foi defrontado com um caso em que o empregador alegou, como excludente da obrigação de indenizar o trabalhador bruscamente dispensado, a "crise de construções reinante nesta Capital [Salvador]". Para o construtor Geraldo Rios a crise econômica era a força maior a caracterizar uma justa causa para a dispensa do empregado Braz Domingos Luiz.

Analisado o ambiente e os processos em linhas mais gerais, identificando a construção de literatura e julgados que já ditavam as primeiras interpretações sobre o "novo direito", entre a interferência estatal, a supervisão constante do Ministério do Trabalho, a solução dos primeiros problemas econômicos e de política judiciária, bem como a convivência constante com as ideias rotuladas na retórica do direito do trabalho da época como "ranço liberal", importa dedicar o próximo item à análise mais profunda de um processo em específico, emblemático seja pelos acontecimentos nele inseridos seja pela abertura à compreensão do funcionamento da burocracia do CNT por ele trazida.

\subsection{Eugenio D'Alessandro contra o "polvo canadense"}

179 "DISSÍDIO COLETIVO. É de competência da Justiça do Trabalho estabelecer condições de trabalho capazes de harmonizar as classes dissidentes, desde que se esgotaram tôdas as possibilidades de conciliação, achando-se em foco o interêsse da coletividade" BRASIL. Jurisprudência: Conselho Nacional do Trabalho, v. XXVIII, Rio de Janeiro, Imprensa Nacional, 1946, pp. 63 e ss. 
Eugênio D'Alessandro era um imigrante italiano, morador do bairro do Riachuelo, cortado pela Estrada de Ferro Central do Brasil, na zona norte do Rio de Janeiro, que em 1934 deu início a um processo em face da Caixa de Aposentadoria e Pensões da The Rio de Janeiro Tramway, Light and Power Company Limited - a conhecida Companhia de Carris, Força e Luz do Rio de Janeiro -, empresa de origem canadense responsável pela distribuição final da energia elétrica na capital desde $1905^{180}$.

Nascido na comuna de Paduli, província de Benevento, ao sul da Itália, ingressou na Light em março de 1912, passando pelas oficinas de Vila Izabel e se firmando na "steam plant" de reserva (usina termoelétrica acionada na falta de energia hidrelétrica), como "Assistente do Engenheiro Chefe", após conquistar a habilitação de maquinista de máquinas à vapor em 20 de abril de 1918. Todas essas informações constam da "Ficha Individual e Declaração de Família do Contribuinte", curiosamente datada de 11 de agosto de 1932 - mais de vinte anos após o ingresso de D’Alessandro nos quadros da companhia -, sem conter a firma do empregado, apresentada pela CAP da Light nos autos do inquérito.

"Brasileiro adotivo" - conforme consta do atestado de revacinação contra a varíola, emitido pelo Inspetoria dos Serviços de Profilaxia do Departamento Nacional de Saúde Pública - Eugenio D’Alessandro parecia ter exacerbados sentimentos nacionalistas, a ponto de dar à sua segunda filha o nome de Victtoria Italia D'Alessandro ${ }^{181}$, nascida já no Rio de Janeiro, em 27 de novembro de 1916. O ato de sua naturalização foi firmado por Getúlio e Oswaldo Aranha em 1 de setembro de 1931.

Eis que, em 02 de fevereiro de 1934, a CAP da Light fez publicar no Jornal do Brasil a decisão pela sua aposentadoria, com apoio no parágrafo $5^{\circ}$ do artigo 53 do Decreto n. 21.081/1932, após longa tramitação administrativa de um inquérito.

\footnotetext{
${ }^{180}$ Em 27 de novembro de 1909, a Light assinou um novo contrato de fornecimento do serviço de iluminação pública da capital, pelo qual se obrigava a manter uma usina termoelétrica de reserva, isto é, para ser acionada em caso de insuficiência de abastecimento de energia hidrelétrica. CNT, Processo n. 1.370/34, fl. 48.

${ }^{181}$ D'Alessandro era membro de movimentos antifascistas da colônia italiana brasileira. O antifascismo de D’Alessandro é comprovado pela sua atuação como fundador do primeiro grupo antifascista brasileiro, a Unione Democratica, no Rio de Janeiro, em dezembro de 1924, ao lado de Giovanni Infante, Giovanni Scala, Armado De Gasperi e outros. Sua conversão ao fascismo é apenas possível, dada a popularidade que o fascismo alcançou posteriormente entre os imigrantes italianos no Rio de Janeiro. Cf. TRENTO, Angelo. Do outro lado do Atlântico: um século de imigração italiana no Brasil. São Paulo: Nobel, 1989, pp. 370-371. Para as apreensões do jornal La Difesa pelo Departamento Estadual de Ordem Política e Social, publicado pela Unione Democratica, cf. CARNEIRO, Maria Luiza; KOSSOY, Boris (org.). A imprensa confiscada pelo DEOPS. São Paulo: Ateliê Editorial/Imprensa Oficial do Estado de São Paulo/Arquivo do Estado, 2003, p. 152.
} 
O Decreto n. 21.081 dispunha sobre as Caixas, os seus associados e os benefícios a eles disponíveis. O mencionado artigo 53 cuidava da estabilidade decenal, retirada do empregado em caso de falta grave, "após deliberação do Conselho Nacional do Trabalho, se êste reconhecer a falta argüida". O parágrafo $5^{\circ}$ continha uma capciosa regra de exceção, permitindo a aposentadoria de "empregados que se tenham tornado desnecessários por ter sido suprimido o serviço ou o departamento das empresas em que trabalhavam em virtude de ter desaparecido o seu objeto ou pela superveniência de novas invenções" $" 182$.

D’Alessandro, adiantando-se à própria CAP, fez chegar ao Conselho Nacional do Trabalho, em 14 de fevereiro de 1934, carta em que dava notícia ao órgão da procedência do inquérito processado na Caixa, que resultou em sua aposentadoria, e já manifestava seu inconformismo. Pedia que lhe fosse informada a chegada do inquérito ao CNT, de modo a "apresentar documentos probatórios (...) pela verdade e pela justiça"183. Houve por bem a Secretaria do CNT também se adiantar e já em março de 1934 solicitou à CAP da Light a remessa dos autos do inquérito de Eugênio D’Alessandro.

Os autos do inquérito revelam que D'Alessandro foi suspenso de suas atividades, em 07 de maio de 1932, e logo submetido ao inquérito administrativo, por contar com mais de dezoito anos de serviços prestados à Light. Apenas em 31 de março de

\footnotetext{
${ }^{182}$ Art. 53. Após dez anos de serviço prestado à mesma empresa, os empregados a que se refere a presente lei só poderão ser demitidos em caso de falta grave, apurada em inquérito, feito pela administração da empresa, ouvido o acusado com a assistência do representante do sindicato da classe, cabendo recurso para o Conselho Nacional do Trabalho.

$\S 1^{\circ} \mathrm{O}$ empregado contra o qual for argüida falta grave poderá ser desde logo suspenso de suas funções pela emprêsa, mas a demissão somente se dará após deliberação do Conselho Nacional do Trabalho, se êste reconhecer a falta argüida.

$\S 2^{\circ}$ No caso de reconhecer o Conselho Nacional do Trabalho a não existência de falta grave ao empregado, fica a empresa obrigada a readmiti-lo no serviço e a indenizá-lo dos salários durante o período de sua suspensão.

$\S 3^{\circ} \mathrm{O}$ empregado demitido, com mais de 10 anos de serviço, poderá continuar como associado da Caixa, pagando em dobro, até perfazer o período de 35 anos, a contribuição, se assim o requerer no prazo máximo de 60 dias da demissão. $\mathrm{O}$ associado nestas condições, a partir de 55 anos de idade, perceberá uma renda vitalícia equivalente à importância da aposentadoria a que teria direito se continuasse em serviço no cargo que ocupava ao ser exonerado, feita a conveniente habilitação perante a Caixa.

$\S 4^{\circ}$ Não se compreendem nêste artigo os cargos de principal responsável pela direção da empresa e outros equivalentes, da confiança imediata dos governos ou das administrações superiores das empresas.

$\S 5^{\circ}$ Não se compreendem igualmente neste artigo os empregados que se tenham tornado desnecessários por ter sido suprimido o serviço ou o departamento das empresas em que trabalhavam em virtude de ter desaparecido o seu objeto ou pela superveniência de novas invenções. Mas nêste caso, os empregados que forem dispensados terão direito de se aposentar, com tantos trinta avos da média dos vencimentos dos últimos três anos quantos forem os anos de serviço de cada um, cabendo às empresas a obrigação de entrar antecipadamente e de uma só vez para as Caixas com a importância global das contribuições dos empregados assim aposentados, bem como manter a sua própria, como se tais empregados continuassem em serviço sujeitando antecipadamente o processo de aposentadoria, com tôdas as informações, ao Conselho Nacional do Trabalho.

${ }^{183}$ CNT, Inicial do Processo n. 1.370/1934, fl. 2.
} 
1933 a Junta Administrativa da CAP decidiu pela suspensão de trinta dias, com prejuízo de vencimentos. Sem manifestar oposição ao decidido, segundo consta do relatório do acórdão do inquérito, D’Alessandro recebeu os ordenados atrasados em abril de 1933 (com o desconto do período de suspensão), sem retornar aos serviços até dezembro do mesmo ano, período em que recebeu salários.

Durante o afastamento de D’Alessandro, o Departamento de Eletricidade da Light propôs a extinção do cargo de "Assistente ao Chefe" por ele ocupado na Usina Térmica de Reserva. A proposta continha as seguintes razões:

"Com referência às nossas trocas de apreciações sobre a organisação da Usina Termica de Reserva, tenho a confirmar que, considerando as condições como atualmente se apresentam, sou de parecer que é desnecessário o serviço de "Assistente ao Chefe" dessa Usina. Desde o mês de Maio do corrente ano, o encarregado desse serviço se acha afastado do seu posto, não causando esse fáto nenhuma alteração nas normas de serviços correlatos à Usina acima referida. Baseado nessa circunstancia, penso que póde ser extinto aquele serviço". ${ }^{184}$

A Superintendência Geral da Light também se manifestou no seguinte sentido:

"Como é de seu conhecimento, novo, moderno e aperfeiçoado aparelho para a distribuição e utilização do oleo combustivel na Usina Termica foi instalado para a bateria de caldeiras n. 1, obra esta prestes a ser terminada. Estes melhoramentos em si recomendam a reconsideração geral sobre as existentes condições, com o fim de reduzir e simplificar, si possivel, a organização do pessoal, sem afetar a eficiencia ou a segurança de operação dessa usina.

(...)

Acresce tambem que o serviço de inspeção de todos os aparelhos para extinção de incendio nas diversas propriedades, sob a jurisdição do Departamento de Eletricidade, se acha reduzido a um serviço de rotina, o qual tem sifo observado ha mais de tres anos. O Chefe da Usina Termica de Reserva, portanto, se acha bastante desobrigado de deveres relativos a esse serviço, os quais estão agora em grande parte a cargo de outros, assim podendo ele dedicar praticamente todo a sua atenção à usina termica. (...) Como ficou esclarecido, durante os seis ultimos mêses, a pratica indicou que a supressão do serviço de "Assistencia ao Chefe" dessa usina deve ser feita, não só do ponto de vista tecnico, como por medida de ordem administrativa" ${ }^{, 185}$.

\footnotetext{
${ }^{184}$ Encaminhamento do Presidente da CAP da Light, K. H. MacCrimmon, endereçado ao relator do inquérito, o gerente Raul de Caracas. Processo n. 1.370/1934, fl. 8.

${ }^{185}$ Encaminhamento do Presidente da CAP da Light, K. H. MacCrimmon, endereçado ao relator do inquérito, o gerente Raul de Caracas. CNT, Processo n. 1.370/1934, fl. 9.
} 
Chama a atenção o fim da manifestação da Superintendência que, após longo parecer técnico sobre minúcias operacionais da usina bem como sobre a ociosidade do cargo de assistência ao chefe, informa que a extinção do cargo dever-se-ia dar "não só do ponto de vista técnico, como por medida de ordem administrativa". Aqui a Light deixa entrever que a dispensa imotivada de D'Alessandro era desejada em suas esferas de gestão, seja qual fosse o argumento técnico ou jurídico subjacente.

O Presidente da CAP cita ainda precedentes do CNT, relativos à aposentadoria de associados da Caixa de Aposentadoria e Pensões da Estrada Férrea Madeira-Mamoré e da própria CAP da Light, e anuncia que a Light providenciaria “de uma só vez":

(i) o recolhimento da "importancia global das contribuições obrigatorias referentes ao tempo que falta a Eugenio D'Alessandro para aposentar-se normalmente";

(ii) recolher "o restante da joia ou contribuição inicial por ele devida";

(iii) manter a contribuição da empresa, como se o referido empregado continuasse em serviço;

(iv) reconhecer o tempo de serviço de vinte anos e seis meses, tomando como termo final a data da manifestação (07 de dezembro de 1933).

Em 07 de fevereiro de 1934, sobreveio decisão da Junta Administrativa pela aposentadoria de D'Alessandro. Nenhuma manifestação deste se observa até então nos autos, embora constem duas convocações endereçadas ao empregado, firmadas pelo gerente da CAP da Light, P. Swanson.

Ato contínuo, o Presidente da CAP determina o depósito da quantia de $\mathrm{R}^{\mathrm{s}}$ 9:505\$500 (nove contos, quinhentos e cinco mil e quinhentos réis), de modo a cumprir a determinação do parágrafo $5^{\circ}$ do artigo 53 do Decreto n. 21.081/1932.

D'Alessandro requereu por mais duas vezes vistas de seu processo de aposentadoria, o que foi deferido apenas em fim de março de 1934. Em 3 de abril de 1934, apresentou seu arrazoado de defesa em dezesseis páginas ${ }^{186}$, em causa própria, sem estar representado por advogado.

Inicia sua autodefesa afirmando que a usina de térmica reserva deveria manter não apenas maquinário apropriado, mas também pessoal de prontidão para operá-la a qualquer momento, pelo que não poderia prescindir de um maquinista legalmente

${ }^{186}$ CNT, Processo n. $1.370 / 1934$, fls. 48-64. 
habilitado como ele. Anexa a suas razões cópia do contrato de fornecimento de iluminação pública firmado pela Light e cita a cláusula contendo a referida obrigação.

Mais adiante invoca o "direito de preferência que a Lei concede aos cidadãos brasileiros" e coloca em dúvida a capacidade e a habilitação dos chefes da usina de reserva, o inglês J. D. Murray e o canadense William Fairlam, aos quais afirma ter substituído em diversas ocasiões, inclusive em períodos de pleno funcionamento da usina. Estrategicamente, menciona que a usina de reserva foi posta a funcionar em outubro de 1930, quando as "forças revolucionárias" tomaram a Usina de Parahyba. Colocou-se ainda como empregado indispensável para o funcionamento da térmica de reserva:

“[E] apezar que essa Usina estivesse, nesse dia, em especiaies condições (...) podendo fornecer energia electrica em meia hora, foram precisas tres horas para que o primeiro gerador pudesse ser ligado nas linhas de distribuição, e isso, so se verificou quando eu cheguei na estação a tomar conta da situação, embora estivessem presentes outros machinistas" ${ }^{\text {"187. }}$.

Apresenta também ofício, datado de 25 de fevereiro de 1930, firmado pelo Superintendente da Divisão de Produção da Light, J. Borgerth, contendo histórico de sua atuação profissional na companhia, fazendo elogios, ressaltando suas qualidades, apontando os aumentos salariais e promoções concedidos, as ocasiões em que substituiu os chefes da usina.

Segue afirmando que houve violação do parágrafo $5^{\circ}$ do artigo 53 do Decreto n. 21.081/32, uma vez que não houve supressão do serviço de assistente do chefe da usina a vapor, por se tratar este de cargo em comissão, podendo ele retornar às atividades de origem como maquinista, bem como pela violação ao contrato de fornecimento de iluminação representada por tal extinção.

Contudo, já na décima página de sua defesa, D’Alessandro comenta os fatos relacionados a um outro inquérito, que antecedeu o que culminou em sua aposentadoria. Trata-se de um inquérito para a apuração de falta grave, que resultou na sanção de suspensão por um mês, à qual supostamente o empregado não se opôs. A punição teria se dado em função da participação de D’Alessandro na greve de 7 de maio de 1932 na Light, tendo liderado empregados na destruição de próprios da companhia, abandonado seu cargo

${ }^{187}$ CNT, Processo n. 1.370/1934, fl. 51. 
de confiança na usina de reserva e mandado recolher os bondes elétricos que integravam o transporte público da capital.

\title{
3.3.1 A greve de 1932 e a condenação do inimigo da Itália
}

As greves de maio de 1932 ocorreram por todo o Brasil. Em São Paulo, houve adesão de duzentos mil trabalhadores, incluindo os trabalhadores da Light. O mesmo ocorreu no Rio de Janeiro. Bondes e máquinas da companhia foram destruídos. Os fatos chegaram ao Ministério do Trabalho, Indústria e Comércio, que houve por bem intervir no sindicato dos trabalhadores da Light. O Diário Oficial de 15 de junho de 1932 (p. 11440) trouxe publicado o despacho sobre a intervenção:

\begin{abstract}
"Em outro processo, instaurado no Departamento Nacional do Trabalho para apurar as responsabilidades dos diretores do Centro dos Operarios e Empregados da Light e Companhias nos acontecimentos ligados à última greve do pessoal da Light and Power, o diretor geral daquele Departamento, de acôrdo com a lei de sindicalização, resolveu destituir a diretoria do mesmo sindicato. Subindo o processo á decisão do Sr. Ministro, proferiu S. Ex., em 10 do mês corrente, o despacho seguinte:

-- Sem entrar na apreciação da decisão, que só por meio de recurso poderei conhecer, nomeio o Sr. Clodoveu de Oliveira, atuario do Departamento Nacional do Trabalho, delegado, de conformidade com o $\S$ $3^{\circ}$, do art. 16, do decreto número 19.770, de 1931, devendo imediatamente assumir sua função, apresentando-me dentro do mais curto prazo um relatorio do estado em que se encontra o sindicato" $" 188$.
\end{abstract}

$\mathrm{O}$ acontecimento não passaria despercebido nem mesmo pelo compositor de marchinhas Luís Silva, que já em 17 de maio de 1932, apenas dez dias após o movimento grevista, teria sua paródia da música "Tá Com Raiva, Fala” publicada no Jornal de $\operatorname{Modinhas}^{189}$ :

\author{
"Os empregados da Light \\ também têm critério \\ A defesa do pão
}

\footnotetext{
${ }^{188}$ Decreto n. 19.770/1931. Art. 16. Salvo os casos previstos nos $\S \S 1^{\circ}$ e $2^{\circ}$ do artigo 13 , o não cumprimento dos dispositivos deste decreto será punido, conforme o caracter e a gravidade de cada infracção, e por decisão do Departamento competente do Ministerio do Trabalho, Industria e Commercio, com multas de $100 \$ 000$ (cem mil réis) a 1:000\$000 (um conto de réis), fechamento do syndicato, da federação ou da confederação, até seis mezes, destituição da directoria ou sua dissolução definitiva.

$\S 3^{\circ} \mathrm{Si}$ a pena consistir na destituição da directoria, nomeará o ministro um delegado, que dirigirá a associação até que, no prazo maximo de 60 dias, em assembléa geral, por elle convocada e presidida, sejam eleitos novo directores.

189 TINHORÃO, José Ramos. Música Popular: um tema em debate. $3^{\text {a }}$ ed. São Paulo: Ed. 34, 1997, pp. 16970 .
} 


\author{
é um caso sério \\ As coisas não andam boas \\ Não se ganha pra comer \\ Querem ganhar mais um pouco \\ assim não podem viver, oi... \\ Os bondes pararam todos, \\ não se tinha condução; \\ os ônibus e automóveis \\ cobravam um dinheirão".
}

D’Alessandro negou com firmeza a participação na greve, alegando que estaria acamado, a "debellar uma gripe". Os chefes da usina, Murray, Fairlam e Borgerth, seus inimigos e detratores, segundo o reclamante, deram início ao inquérito, implicando-o na greve. Teriam estes agrupado testemunhas, incluindo o "páo mandado" Bernarde de Souza Lima, que o teria qualificado de "subversivo" no depoimento prestado perante a Junta Administrativa da CAP da Light. Outros três fiscais relataram que "mais ou menos" viram D’Alessandro cuidar, "entre o lusco-fusco", do recolhimento dos bondes.

Dez foram as testemunhas ouvidas a rogo de D’Alessandro. Nenhum desses depoimentos foi mencionado na decisão da Junta, tudo segundo o próprio D’Alessandro, ao trazer em sua defesa os antecedentes que compunham o pano de fundo do processo de aposentadoria.

Durante toda a longa tramitação do inquérito administrativo para a apuração da falta grave, os salários de D'Alessandro foram pagos sob aprovação do Superintendente Geral da Light, J. M. Bell, que emitia memorandos mensais de próprio punho em língua inglesa ${ }^{190}$, autorizando o pagamento. A figura de Eugenio D’Alessandro povoava de forma especial as pautas e preocupações dos altos dirigentes da Light.

Cópias de peças do inquérito foram negadas pessoalmente a D’Alessandro pelo advogado da Light, Alcebíades Delamare, em reunião cujo teor ficou registrado em carta enviada ao empregado pela própria Superintendência Geral da Light ${ }^{191}$.

D’Alessandro provavelmente conhecia Alcebíades Delamare, seja pela sua fama como jurista, advogado, jornalista e literato, seja por embates anteriores no seio da própria Light.

Perceba-se que os autos não estavam disponíveis aos interessados na sede da CAP da Light, como seria o mais natural. Estavam guardados pelo advogado da

\footnotetext{
${ }^{190}$ CNT, Processo n. 1.370/1934, fls. 85-86.

${ }^{191}$ CNT, Processo n. $1.370 / 1934$, fl. 76.
} 
companhia, que alegava somente o seu arquivamento para negar vistas a D'Alessandro. A possível simpatia pelo fascismo ${ }^{192}$, e a alegada liderança grevista simultaneamente aproximavam e distanciavam o maquinista D'Alessandro do advogado Delamare.

Alcebíades Delamare Nogueira da Gama fora Secretário de Governo de Epitácio Pessoa. Foi fundador e diretor da revista Gil Blas, de 1919 a 1923, que veiculou conteúdo nacionalista, católico, antianarquista e lusófobo ${ }^{193}$, seguindo o pensamento de Alberto Torres e defendendo as demandas dos trabalhadores dentro dos princípios da Rerum Novarum. A Gil Blas apoiou a candidatura de Epitácio Pessoa já no ano de sua fundação. Membro de primeira hora da Ação Integralista Brasileira ${ }^{194}$, lançada em 7 de outubro de 1932, com o Manifesto de Outubro, redigido por Plínio Salgado, Delamare circulara antes entre os líderes do movimento de tradicionalismo católico encabeçado por

192 Cf. BERTONHA, João Fábio. Sob a sombra de Mussolini: os italianos de São Paulo e a luta contra o fascismo, 1919-1945. São Paulo: Annablume, 1999, p. 251, nota n. 638. Bertonha revela que D'Alessandro era um militante antifascista que possivelmente se converteu ao fascismo.

${ }^{193}$ Cf. JESUS, C. G. N. de. Revista Gil Blas e o nacionalismo de combate (1919-1923). Assis, 2011. 202 p. Dissertação de Doutorado - Faculdade de Ciências e Letras, Campus Assis, Universidade Estadual Paulista. Disponível em: http:/www. athena. biblioteca. unesp.br/ exlibris/bd/bas/ 33004048018P5/ 2011/jesus cgn_dr_assis_parcial.pdf. Acesso em: 18 nov 2012; e, GOMES, Angela de Castro. A invenção do trabalhismo. $3^{\text {a }}$ ed. Rio de Janeiro: Editora FGV, 2005, p. 137.

194 Delamare viria a ser membro do Diretório Nacional do Partido de Representação Popular, fundado por Plínio Salgado, em 26 de setembro de 1945, para reagrupar os ex-integrantes da Ação Integralista Brasileira, dissolvida em final de 1937. A "ameaça comunista", surgida com a intentona de 1935 e reorganizada por meio do Plano Cohen, inspirou o novo regime partidário concebido por Francisco Campos, que decretou o fim do pluripartidarismo e impediu a ação de quaisquer forças oposicionistas. De apoiador do golpe varguista, tendo tratado diretamente com Getúlio a sua indicação para a pasta da Educação, Plínio Salgado se vê na clandestinidade e acusado de ser o mentor do Plano Cohen, levante do qual deliberadamente se distanciara. Preso na Fortaleza de Santa Cruz e enviado ao exílio em Portugal em julho de 1939, Salgado reordenaria sua ideologia, abandonando o antigo antissistemismo revolucionário da AIB e passando a conformar-se ao jogo eleitoral democrático. Ainda que as questões políticas não tenham sido esquecidas, averígua-se um crescente envolvimento de Salgado com a religiosidade e a linguagem cristã desponta em vários de seus escritos. Salgado seria candidato do PRP para a Presidência nas eleições de 1955, vencidas por Juscelino Kubitschek. O partido foi novamente extinto pela ditadura militar, por intermédio do Ato Institucional Número Dois, o AI-2, de 27 de outubro de 1965. Cf. CALIL, Gilberto. Partido de Representação Popular: estrutura interna e inserção eleitoral (1945-1965). Rev. Bras. Ciênc. Polít., Brasília, n. 5, jul 2011. Disponível em: <http:// www. scielo.br/ scielo.php? script=sci_arttext\&pid =S0103 -33522011000100013 $\& \operatorname{lng}=$ en\&nrm=iso $>$. Acesso em: 15 nov. 2011; e, MOREIRA, C. V.. Revanche verde: O Partido de Representação Popular na experiência democrática brasileira (1945-1964). Anais do XV Encontro Regional de História da ANPUH-Rio, Rio de Janeiro, julho 2012. Disponível em: http:// www. encontro2012.rj.anpuh.org/ resources/anais/ 15/1332851589_ARQUIVO_Artigocleitonvieiramoreiraprp.pdf . Acesso em: 15 set 2012. "Segundo Olbiano de Melo, depois de tentar obter o apoio da AIB para o golpe de 1937, Getúlio prosseguiu em suas negociações com os integralistas mesmo após a extinção dos partidos, oferecendo-lhes o Ministério da Educação. A liderança do movimento chegou a escolher o nome de Gustavo Barroso para a pasta, mas a indicação, transmitida por Alcebíades Delamare a Francisco Campos para que este a levasse até Vargas, jamais chegou a seu destino. Entretanto, a mudança de posição dos integralistas em relação ao novo regime foi rápida. No início de 1938, um grupo de oficiais da Marinha chefiado pelo comandante Vítor Pujol reuniu-se com Miguel Reale e Gustavo Barroso para propor um levante armado, que seria levado a cabo com ou sem o apoio de civis e teria como alvo principal o palácio Guanabara". Cf. FGV. CPDOC. Dicionário Histórico Biográfico Brasileiro: verbete Gustavo Barroso. Rio de Janeiro, 2010. Disponível em: <http://www.fgv.br/cpdoc>. Acesso em: 13 abr 2011. O Dicionário do CPDOC oferece outra versão, segundo a qual Gustavo Barroso seria o indicado para a pasta da Educação. 
Jackson de Figueiredo, no Centro Dom Vital, principal entidade do laicato católico brasileiro à época, e que seria uma das sementes da democracia cristã no Brasil ${ }^{195}$. Tinha atuação destacada na capital como jornalista, ensaísta e professor de Direito Administrativo da Faculdade de Direito da Universidade do Brasil. Obtivera o título de bacharel em Direito pela Faculdade de Direito da Universidade de São Paulo, tendo sido presidente do Centro Acadêmico XI de Agosto em 1910. Já em 1917 obteve o grau de doutor em direito pela Universidade do Rio de Janeiro ${ }^{196}$.

Diante desse quadro de atuações políticas e filiações ideológicas, é quase certo que Alcebíades Delamare também conhecia Eugenio D'Alessandro fora do âmbito do patrocínio dos interesses da Light. Por isso o teria recebido pessoalmente para tratar de seu caso e, em especial, de seu pedido de vista e extração de cópias dos autos do inquérito administrativo, conforme comprovado nos autos do processo de aposentadoria.

O que talvez não soubesse D’Alessandro é que a perseguição que lhe era dirigida extrapolava em muito os muros da Light e de seu relacionamento cotidiano com os chefes ingleses e canadenses. D'Alessandro era conhecido entre os imigrantes italianos e até mesmo pelo governo da Itália. A Embaixada da Itália no Brasil já vinha buscando sua demissão na Light desde 1928, por meio de gestões junto à polícia política varguista, a DESPS.

\subsubsection{O "exista" inofensivo}

\footnotetext{
${ }^{195}$ Em 1922, Jackson de Figueiredo, convertido em 1918 ao catolicismo por Dom Sebastião Leme, que seria seu mentor a partir de então, funda o Centro Dom Vital e a revista $A$ Ordem, como seu meio de divulgação de ideias, no Rio de Janeiro, que duraria até 1964. Foi, sob a direção de Jackson, até sua morte, uma revista tradicionalista e, ao depois, sob a direção de Alceu Amoroso Lima, até 1937, abrigo constante de tradicionalistas. Nesse ano, a Guerra Civil Espanhola dividiu os católicos brasileiros, deixando na Ordem os maritainianos progressistas; os tradicionalistas procuram abrigo noutras revistas. Cf. CRIPPA, A. As idéias políticas no Brasil. v. 2. São Paulo: Ed. Convívio, 1979. Verbete "O Tradicionalismo Brasileiro" disponível em: <http://www.cdpb.org.br/html/estudos_destacados_tradbrasileiro.html >. Acesso em: 3 mai 2011. Alceu Amoroso Lima aderiu ao modernismo em 1922, sendo responsável por importantes estudos sobre os principais poetas do movimento. Travou debates em trocas de cartas com Jackson de Figueiredo, dos quais decorreu sua conversão ao catolicismo em 1928. Após a morte de Jackson de Figueiredo, substituiu-o na direção do Centro Dom Vital e da revista A Ordem. Foi representante brasileiro no Concílio Vaticano II, o que o marcaria profundamente. Foi um dos fundadores do Movimento Democrata-Cristão no Brasil. Cf. LEONÍDIO, A. Notas de pesquisa sobre a correspondência entre Alceu Amoroso Lima e Jackson de Figueiredo (1919-1928). Rev. de Hist. e Est. Cult., São Paulo, n. 1, v. 4, jan-mar 2007. Disponível em: $<$ http://www.revistafenix.pro.br/PDF10/ARTIGO3.SECAO.LIVRE.Adalmir.Leonidio.pdf>. Acesso em: 23 de agosto de 2012.
}

${ }^{196}$ BARATA, C.E.A.; BUENO, A.H.C. Dicionário das famílias brasileiras. São Paulo: Originis-X, 1999. 
A Delegacia Especial de Segurança Política e Social (DESPS) foi criada em 10 de janeiro de 1933 por meio do Decreto n. 22.332, com o objetivo de entrever e coibir comportamentos políticos divergentes, considerados capazes de comprometer a ordem e a segurança pública. Era diretamente subordinada à Chefia de Polícia do Distrito Federal e possuía uma tropa de elite, a Polícia Especial. Tinha por atribuição examinar publicações nacionais e estrangeiras e manter dossiês de todas as organizações políticas e indivíduos considerados suspeitos. A DESPS serviu de modelo para a criação de delegacias estaduais, já que à Chefia de Polícia do Distrito Federal cabia determinar as diretrizes básicas do controle social a ser exercido pelas polícias dos estados, ainda que estas fossem formalmente subordinadas aos governos locais. Para essa centralização foi decisiva a atuação de Filinto Müller, homem de confiança de Vargas e chefe de Polícia do Distrito Federal de 1933 a 1942.

As atividades da polícia política iriam se intensificar em meados da década de 1930, sob o pretexto de combater manifestações perturbadoras da ordem. O rápido crescimento da Aliança Nacional Libertadora justificou a promulgação, em 4 de abril de 1935, da Lei de Segurança Nacional, definindo crimes contra a ordem política e social. Em seguida, a Intentona Comunista de novembro serviu para justificar o aumento da ação repressiva contra todos aqueles que possuíssem vínculos reais ou presumidos com o Partido Comunista do Brasil e o comunismo internacional. A instauração do Estado Novo em 1937, o levante integralista em 1938 e o desenrolar da Segunda Guerra Mundial reforçaram a tendência à criminalização de toda e qualquer dissidência política em relação ao governo. Juntaram-se assim aos comunistas, como alvo das ações repressivas, os integralistas e os "estrangeiros nocivos", considerados difusores de "ideologias exóticas".

A transformação da Chefia de Polícia do Distrito Federal em Departamento Federal de Segurança Pública (DFSP) pelo Decreto $\mathrm{n}^{\circ} 6.378$, de 1944, foi parte de uma reforma do Poder Judiciário realizada durante o Estado Novo. A DESPS tornou-se então a Divisão de Polícia Política e Social, com duas delegacias, uma responsável pela matéria política e outra pela matéria social. Essas delegacias dariam continuidade à política de especialização dos serviços referentes à segurança pública e seguiriam orientando o controle político e social após a queda de Vargas em $1945^{197}$.

\footnotetext{
${ }^{197}$ As informações sobre a DESPS foram extraídas de FGV. CPDOC. Navegando na História - A Era Vargas: dos anos 20 a 1945, Anos de Incerteza - Polícia política. São Paulo, 1997. Disponível em: < http:// cpdoc.fgv.br/ producao/dossies/ AEraVargas1/ anos30-37/RadicalizacaoPolitica/PoliciaPolitica $>$. Acesso em: 16 out. 2011.
} 
$\mathrm{O}$ inquérito policial para investigar Eugenio D’Alessandro foi aberto em $1943^{198}$. Havendo indícios, seria enviado ao Tribunal de Segurança Nacional. Os autos contêm apenas termos de depoimentos de colegas de trabalho e chefes de D'Alessandro, além de dois relatórios, da Secção de Segurança Social e do delegado Zildo José Jorge, respectivamente. Não há notícia de quem teria denunciado D’Alessandro como agitador subversivo, mas a tradução de cartas trocadas entre D’Alessandro e a Embaixada da Itália faz presumir uma provável denúncia por parte da representação italiana no Brasil.

Em um primeiro depoimento nos autos D'Alessandro relata que mantinha excelente relacionamento com seu antigo chefe, William Lipincot, que o teria estimulado a se qualificar como maquinista, além de tê-lo promovido. $\mathrm{O}$ falecimento de Lipincot em dezembro de 1924 levou à ascensão de "Arnaldo" Borgerth e “João" Drumond Murray à chefia da usina de reserva. D'Alessandro faz elogios a Borgerth, mas revela que Murray o perseguiu desde o início. Continuou negando participação na greve de 7 de maio de 1932, relatando que teria sido chamado à DESPS às vésperas do movimento paredista, tendo sido "aconselhado" a não aderir à paralisação, sob o argumento, lançado pelo Capitão João Alberto, segundo o qual os empregados da usina tinham a "missão humanitária" de prover energia a hospitais, escolas e residências. O Tenente Pedro Teixeira Mazolleni o interpelara "se o Governo podia contar com o pessoal da usina"199. Repetiu ainda que estava doente no dia deflagração da greve e que já no dia 8 de maio de 1932 foi proibido de entrar na usina de reserva, sendo comunicado da abertura do inquérito para a apuração de falta grave.

Foram treze sessões até a conclusão do inquérito em 28 de abril de 1933. Nos depoimentos foi elogiado por Murray e acusado de sabotagem por Borgerth. Os participantes da greve foram processados criminalmente e D'Alessandro não estava arrolado entre os réus, que foram todos absolvidos em maio de 1933. D’Alessandro prossegue relatando os processos que mantinha no CNT em face da Light, bem como o bem sucedido processo de execução perante a justiça comum.

Resta ainda apurado no inquérito que D'Alessandro mantinha ligação com a Embaixada da Itália, onde foi recebido em audiência. Também trocou correspondências com diretores do Partido Fascista bem como com autoridades de órgão governamental italiano de preservação de florestas, tendo se apresentado como especialista no tema e "professor".

${ }^{198}$ APERJ, Acervo DESPS, Inquérito n. 41/1943, notação n. 108.

199 APERJ, Acervo DESPS, Inquérito n. 41/1943, notação n. 108, fl. 5. 
As acusações de sabotagem são lastreadas apenas em depoimento de Manoel Novoa Blanco, que afirmou que D’Alessandro lhe sugeriu colocar arame em uma válvula, de modo a lhe prejudicar o funcionamento.

Os empregados ouvidos são unânimes em afirmar a condição de "eixista" de D'Alessandro, afirmando tê-lo ouvido falar em diversas ocasiões que "americanos e ingleses entrariam no chicote" quando a Itália ganhasse a guerra; o mesmo ocorreria com o Brasil, que cometera "grave erro" ao apoiar os aliados. Quanto aos boicotes propriamente ditos, muitos levantam suspeitas, mas nenhum afirma ter presenciado ou saber com certeza que tenha D'Alessandro cometido qualquer ato para colocar em risco a segurança da usina de reserva.

Nos autos estão traduzidos documentos redigidos em italiano por D'Alessandro. O primeiro é uma carta publicada em "A Manhã"200, sem referência à data, com o título "Carta aberta ao cavalheiro Attilio Bianchini". Na carta rebate ofensas e acusações feitas por Biachini junto à "colônia", de que D’Alessandro teria deixado de empregar um seu indicado por ser fascista.

Daí seguem-se várias traduções dos documentos juntados aos autos em língua italiana, provavelmente pela denunciante Embaixada da Itália.

O primeiro consiste em uma carta enviada pelo Presidente da Comissão Nacional Florestal da Itália, A. Starace, a Eugenio D’Alessandro:

\footnotetext{
"Comissão Nacional Florestal - Emblema do Fascio - 'Eu amo as arvores, defendei-as, ajudar-vos-ei a defendê-las' Mussolini - Roma, 20 de janeiro de 1933 - XIo - Palácio do Littorio - Corço Victorio Emmanuele 170 - Ao Snr. Eugenio D’Alessandro (...) Veio às minhas mãos a sua carta de 23 de dezembro último passado da qual depreendo que, com fervor silvestre, vossa senhoria segue os progressos florestais da Itália e os difunde nêsse País.

Agradeço-vos pelas revistas que gentilmente me enviou e que sempre receberei com prazer.

Ordenei que em troca seja enviado a V. S. o nosso periódico "O Bosque" [Il Legno]. Com as melhores saudações, o Secretário do Partido Presidente da Comissão Nacional Florestal"201.
}

Segue-se outra carta da Real Embaixada da Itália no Rio de Janeiro de conteúdo neutro, nada "subversivo":

\footnotetext{
${ }^{200}$ APERJ, Acervo DESPS, Inquérito n. 41/1943, notação n. 108, fls. 21-22.

${ }^{201}$ APERJ, Acervo DESPS, Inquérito n. 41/1943, notação n. 108, fl. 39.
} 
"Rio de Janeiro, 12 de agosto de 1932 - Xo - n. 1866 Prezadíssimo Senhor,

Recebi o fascículo da "Revista Florestal" na qual foi publicado o vosso interessante artigo sôbre a organização dos serviços florestais da Itália.

Enquanto me apraz notar a obra que V. S. desenvolve para tornar conhecida no Brasil uma das organizações estatais à qual o Fascismo decidiu dar vida mais fecunda, agradeço-vos vivamente pela cortezia da remessa.

(...)

O Real Embaixador - P. Cerruti",202.

Mais adiante consta tradução de uma correspondência por meio da qual o Primeiro Secretário da Embaixada da Itália comunicou a D’Alessandro que o Embaixador o receberia em audiência em 21 de maio de 1941, às $12 \mathrm{~h} 15^{203}$.

E, por fim, resta traduzida uma carta de resposta do Secretário do Partido Nacional Fascista a D'Alessandro:

"Partido Nacional Fascista - Diretoria Nacional - Palácio Littorio - 14 via del sudario - Roma - Corço Victorio Eman. 116 - Secretaría Política - Roma, 24-10-936 - XIVo - D. P.

Ao Professor Eugenio D'Alessandro,

(...)

Recebi a sua carta de 18 de setembro - XIVo e a ampl,a relação sôbre 'A Primeira Conferência Brasileira Para a Proteção da Natureza".

Agradeço-vos pela gentileza e expresso-vos o meu prazes pela vossa patriótica colaboração com tão importante conferência. E não saberia si não encorajar-vos no vosso propósito de tornar conhecido e sempre mais amado pelos jovens brasileiros as escolas florestais da Itália. Preservar é atitude fascista.

O Secretário do PNF, Achille Starace" ${ }^{204}$.

Em novo depoimento ${ }^{205}$, D’Alessandro afirma ter sido membro da Associação Brasileira de Imprensa e que não mantinha relações com os embaixadores fascistas, por ser antifascista. Mas relata ter mantido boa amizade com Hugo Sola, embaixador fascista, "amizade essa sem qualquer côr política". Queria apenas conseguir bolsas para moços brasileiros em escolas florestais italianas. Dizendo-se inofensivo, arrola Pedro Mazolleni como sua testemunha.

A relação de D’Alessandro com o fascismo é dúbia, talvez propositadamente, um deliberado jogo duplo de sobrevivência política e social.

\footnotetext{
${ }^{202}$ APERJ, Acervo DESPS, Inquérito n. 41/1943, notação n. 108, fl. 39.

${ }^{203}$ APERJ, Acervo DESPS, Inquérito n. 41/1943, notação n. 108, fl. 40.

${ }^{204}$ APERJ, Acervo DESPS, Inquérito n. 41/1943, notação n. 108, fl. 40.

${ }^{205}$ APERJ, Acervo DESPS, Inquérito n. 41/1943, notação n. 108, fl. 45 verso.
} 
O Relatório da Secção de Segurança Social da DESPS assim conclui:

"Pelo expôsto, se verifica que o estado de ânimo dos funcionários da Usina da Reserva, para com D'Alessandro, quer como funcionário, quer como elemento social, é francamente desfavorável. D'Alessandro sempre se revelou possuidor de espírito irriquieto, intrometido, reclamador, arvorando-se à elemento importante e quiçá insubstituível no local em que vinha trabalhando, julgando-se mesmo, singular no seu setor. Nos dias que correm, já não mais se manifesta, isolado como está, e conservado à distância pelos demais funcionários, faltando-lhe auditório para dar expansão à sua egocentria. D'Alessandro, depois que moveu a ação contra a Light, sendo reintegrado por sentença no seu cargo, a 23.12.940, recebendo a indenização de Cr\$ 140.000,00, tornou-se indiscutivelmente inconveniênte à disciplina no meio operário, atribuindo-se a si mesmo, a qualidade de unico elemento capaz de se digladiar com essa poderosa emprêza, e se comprazendo em criar casos, onde não faltou mesmo o plano de sabotagem de que trata a Informação n. 275/S-2 [não consta dos autos do inquérito], aqui apensa. D'Alessandro tem usado o ardil de endereçar telegramas à todas as autoridades do Paíz, onde não se exclue a pessoa do próprio Presidênte da República, atribuindo-se a qualidade de vítima, e quando se dá o caso de obter uma resposta, exibe-a aos seus colegas, para significar que é um elemento de prestígio, relacionado com as altas autoridades e o protagonista de notavel façanha, qual seja a de viver em constante pugna com uma Companhia contra a qual, ninguem consegue apor vantagens. Não ha a contestar que Eugenio D'Alessandro, jamais se integrará em suas funcções de funcionário daquela Companhia, para se dedicar a um trabalho produtivo, pois alem das várias manifestações de desagrado e mesmo hostilidade que tem revelado com a mesma, sua unica preocupação enquanto lá estiver, será a de criar situações que permitam prosseguir nas suas polemicas e demandas. D'Alessandro, tem se conduzido de tal maneira, que se diria, obteve seu titulo de cidadania brasileira, por conveniência, e dele vem se servindo para melhor ver concretisado seus designios não raros inconfessaveis. Diante do exposto, ocorre-me sugerir o afastamento de Eugenio D'Alessandro, das suas funções da Companhia de Carris Luz e Força do Rio de Janeiro.

(...)

Em face da fragilidade dos argumentos que positivam a culpabilidade de D'Alessandro, ainda que tudo pudesse justificar intenções suas pouco louvaveis para com a Companhia que se lhe tornou desaféta, os resultados colhidos com as diligências em torno do mesmo, não autorizam subordinar-lhe a paternidade de planos de 'sabotagem' e a responsabilidade, ainda que intelectual, da preparação de átos daquela naturêza" ${ }^{206}$.

O relatório ainda o aponta como "mau funcionário", "elemento social nocivo", "inconveniente à disciplina do meio operário" e "partidário do eixo", o que foi inferido dos depoimentos dos empregados da Light que trabalhavam na Usina de Reserva.

${ }^{206}$ APERJ, Acervo DESPS, Inquérito n. 41/1943, notação n. 108, fls. 7-8. 
Embora o relatório reconheça que “os fatos articulados contra D'Alessandro, não configuravam perfeitamente qualquer delito de naturêza política ou social”, conclui que "existindo provas circunstânciais contra o sindicado, parece-me, devem ser ratificadas em inquérito regular, tanto mais quanto, no caso, cabe o seu julgamento ao Egrégio Tribunal de Segurança Nacional, que pode julgar por livre convicção, consoânte o art. 13 do Decreto Lei n. 88 de 20 de dez. de 1937"207.

Em seu relatório, o delegado Zildo José Jorge considerou frágil a prova:

"Em face da fragilidade dos argumentos que positivem a culpabilidade de D'Alessandro, ainda que tudo pudesse justificar intenções pouco louváveis para com a Cia., que se lhe tornou desaféta, os resultados colhidos com as diligências em torno do mesmo, não autorizam subordinar-lhe a paternidade de planos de 'sabotagem', ainda que intelectual, da preparação de atos daquela naturêza" ${ }^{208}$.

O delegado ainda expôs que:

"É certo que, posteriormente, o Chefe da Segurança Social, sugeriu o 'afastamento de Eugenio D'Alessandro das suas funções da Cia. Carris Luz e Força do Rio de Janeiro', em virtude das sindicancias realizadas em torno dos itens formulados pelo Snr. Dele. Especial. E, ainda em seguida, novas investigações foram realizadas no sentido de objetivar a responsabilidade do indiciado. Não nos parece, contudo, como já acentuamos, que esteja perfeitamente configurado o delito que the é atribuido" ${ }^{209}$.

E termina afirmando:

“De outro lado, tudo que existe contra D'Alessandro, segundo o próprio
Assitênte Técnico da DESPS, são apenas 'suspeitas partidas de
companheiros de trabalho', e isto, parece pouco para autorizar um
procedimento regular" ${ }^{210}$.

Finda o inquérito, não há notícia nos autos de que tenha havido efetivamente o seu encaminhamento ao Tribunal de Segurança Nacional.

\subsubsection{A suspensão}

\footnotetext{
${ }^{207}$ APERJ, Acervo DESPS, Inquérito n. 41/1943, notação n. 108, fl. 10.

${ }^{208}$ APERJ, Acervo DESPS, Inquérito n. 41/1943, notação n. 108, fls. 10-11.

${ }^{209}$ APERJ, Acervo DESPS, Inquérito n. 41/1943, notação n. 108, fl. 12.

${ }^{210}$ APERJ, Acervo DESPS, Inquérito n. 41/1943, notação n. 108, fl. 13.
} 
Juntando-se a afirmada participação na greve de maio de 1932 e o histórico de perseguições a Eugenio D'Alessandro, a repentina aposentadoria, unilateralmente levada adiante pela Light, com motivações obscuras e até certo ponto subjetivas, começa a ter sua legitimidade colocada em dúvida.

Uma carta de D'Alessandro, dirigida ao Superintendente Geral da Light, J. M. Bell, datada de 03 de abril de 1933, e anexada com a defesa nos autos do processo de aposentadoria, registra que Alcebíades Delamare convocara o comparecimento pessoal de D’Alessandro a seu gabinete para ouvir a leitura da decisão da Junta no inquérito para a apuração de falta grave. Lera ainda parecer emitido pelo próprio J. M. Bell após a decisão, reduzindo a pena para um mês de suspensão e "reembolso da diferença dos ordenados", em vista da "brilhante fé-de-officio" 211 do empregado na companhia.

D’Alessandro, alegando resguardo de sua honra, manifestou a Delamare que "não podia acceitar nem uma hora de suspenção a titulo de punição"212. Disse ainda:

"Por isso si falta grave, semi-grave, ou simples, se affigura existir, na minha conducta, sobre a qual foi alinhavada a queixa e o inquérito respectivo, só mereço agravante e não attenuante" ${ }^{\text {213 }}$.

Passada a defesa da honra, D’Alessandro coloca em dúvida a independência da Junta Administrativa da CAP da Light, presidida por empregados estrangeiros da companhia, a apreciação unilateral do caso e a idoneidade das testemunhas trazidas pela Light.

Insurge-se, ainda, quanto à negativa de vistas e cópias do inquérito, limitada sua ciência à "palestra do Dr. Delamare" 214 , e finaliza pedindo a revisão do inquérito (mas não o encaminhamento ao CNT), sob pena de tornar pública a "situação creada":

"[R]esta-me pedir que o exame do mesmo se fizesse fora dos muros da Light and Power, onde com maior liberdade e em um ambiente insuspeito, pudesse com segurança, apurar a verdade que tanto interessa a V. S. e a toda a Digna Directoria da Empresa.

(...)

${ }^{211}$ CNT, Processo n. 1.370/1934, fl. 90.

${ }^{212}$ CNT, Processo n. 1.370/1934, fl. 90.

${ }^{213}$ CNT, Processo n. 1.370/1934, fl. 90.

${ }^{214}$ CNT, Processo n. 1.370/1934, fl. 91. 
Visto que a minha suspenção, já está alcançando ONZE MESES dando margem para que as pessoas que me honraram com a propria amizade, façam as mais variadas supposições a meu respeito, me vejo na DURÍSSIMA necessidade dar a conhecer publicamente a situação creada" ${ }^{215}$.

Essa teria sido a única manifestação de D’Alessandro no inquérito para a apuração de falta grave, consistente em sua irresignação com o resultado, na forma de um apelo dirigido ao Superintendente Geral, J. M. Bell.

Todavia, apensado aos autos do processo de aposentadoria está o apelo de D’Alessandro ao CNT contra a sanção pela suposta participação na greve de maio de $1932^{216}$. Trata-se de um recurso interposto em face da decisão do Conselho Regional do Trabalho da $1^{\text {a }}$ Região (Rio de Janeiro), que manteve a decisão tirada no inquérito para a apuração da falta grave.

Novamente D'Alessandro postula por si, sem o auxílio de advogado. Reafirma não haver prova da falta grave bem como reclama da desconsideração dos depoimentos da 10 (dez) testemunhas que apresentou ao longo da instrução. Ao final, demonstra conhecimento da novel legislação, e faz pedido de "revisão do inquerito" com fundamento jurídico típico do "novo direito", afirmando ser o seu um "caso omisso":

\begin{abstract}
"Mas a vista de que a Lei 20.465 de $1^{\circ}$ de outubro de 1931 no seu art. 80, taxativamente dispõe que, os casos omissos serão resolvidos pelo C.N.T., e atendendo que a mesma Lei nada diz respeito sobre a revisão dos inqueritos administrativos, REQUEIRO a revisão do dito inquerito afim de obter o cancelamento da nota lançada na Carteira de Empregado, e o reembolso do vencimento correspondente a esse mez de suspensão, se a Justiça desse C.N.T. se pronuncia a meu favor"217.
\end{abstract}

E ainda fecha a petição colocando em dúvida a boa-fé processual da Light:

"Dada a gravidade de que se reveste o facto; attendendo que a accusada
empregara todos os meios para fugir a essa revisão e considerado que
poderá ella destruir algumas provas, é imprescindivel empregar as
precauções precisas." 218

O fundamento invocado é mais uma das formas pelas quais se pleiteava um julgamento por equidade, uma espécie de clamor por justiça apesar da lei.

\footnotetext{
${ }^{215}$ CNT, Processo n. 1.370/1934, fl. 91.

${ }^{216}$ CNT, Processo n. 5.321/35.

${ }^{217}$ CNT, Processo n. 5.321/1935, fl. 2.

${ }^{218}$ CNT, Processo n. 5.321/1935, fl. 3.
} 
O CNT dá vistas à Light e requisita os autos do inquérito. A Light traz aos autos uma "copia photostatica" do recibo de quitação passado por D’Alessandro à época da punição, passado na presença de "3 testemunhas idoneas", do qual consta haver recebido a quantia de 12:967\$700 (doze contos e novecentos e sessenta e sete mil e setecentos réis), descontados os salários correspondentes ao período de punição. A Light defende que tal recibo se presta a comprovar “haver [Eugenio D'Alessandro] se conformado com a pena de 30 dias de suspensão"219.

O processo vai à pauta e a $1^{\text {a }}$ Câmara do CNT nega provimento ao recurso de D'Alessandro, sob o fundamento da carência de competência para intervir em casos em que não tenha havido demissão de estável. Segundo a Câmara, “em relação a suspensões, desde que pelo seu exagero não ameacem a garantia de estabilidade, não cabe a este Conselho intervir" ${ }^{, 220}$. Decidiu-se ainda aplicar por analogia o artigo $99^{221}$ do Regulamento do Instituto de Aposentadorias e Pensões dos Bancários (Decreto n. 54, de 12 de setembro de 1934), que "tolera as suspensões até 3 mezes (...), e o reclamante foi suspenso por 30 dias tão somente",222.

E D'Alessandro apresenta pedido de reconsideração, defendendo a tese da "revisão do inquérito":

“[T]enho que declarar que houve um extenso 'qui-pro-quo', primeiro na leitura do exposto; deixando de apreciar os consideratum, devido ao equivoco inicial; o qual, uma vez exclarecido, modificará a physionomia do facto e das consequencias.

Não reclamei contra a punição de um mez de suspenção, imposta pelo Empregador Light and Power desta Capital, em consequencia de um inquerito administrativo, ao qual SERENAMENTE respondi; e sim REQUERI ao C.N.T. a REVISÃO DESSE INQUERITO; cousa parecida, mas um tanto differente; e por se tratar de materia não prevista pela Lei; e porque essa Lei, autoriza o C.N.T. a se pronunciar nos casos omissos; ahi está a razão do meu pedido."223

Sobrevém novo indeferimento:

"Considerando que o reclamante pretende, agora, ver equivoco no referido accorrdão, porque o mesmo se refere a 'reclamação contra suspensão' e não a 'pedido de revisão de inquerito', todavia, embora não

\footnotetext{
${ }^{219}$ CNT, Processo n. 5.321/1935, fls. 8-9.

${ }^{220}$ CNT, Processo n. 5.321/1935, fl. 13.

${ }^{221}$ Art. 99. Considera-se demittido o empregado suspenso por mais de noventa dias sem vencimentos ou com reducção dos mesmos.

${ }^{222}$ CNT, Processo n. 5.321/1935, fl. 13.

${ }^{223}$ CNT, Processo n. 5.321/1935, fl. 16.
} 
repetisse as suas palavras, o referido julgado significou a mesma cousa, por isto que o reclamante protestava era, em ultima analyse, contra a suspensão, pedindo a suppressão de seus effeitos -- nota na caderneta e privação de vencimentos -- o que o mesmo reclamante acreditava pudesse ser feito mediante revisão do inquerito a que foi submettido (...), [R] esolvem os membros da $1^{\text {a }}$ Câmara do Conselho Nacional do Trabalho julgar improcedente a reclamação",224.

Já em 22 de janeiro de 1936, D’Alessandro apresenta recurso de embargos, renovando sua indignação e expondo sua preocupação com a anotação da penalidade na carteira de empregado:

"[S]e essa Carteira de Empregado, (...) possue valor legal e acima de tudo, valor MORAL, penso que todos os actos que a ella se relcionam devem ser revestidos de perfeita seriedade, honestidade e Justiça; se não por outra razão, pelo menos em homenagem à dignidade Nacional., 225

O acórdão demonstra já certa impaciência com a insistência do reclamante:

"Considerando, outrossim, que os argumentos por este lançados são de todo impertinentes, senão curiosos, pelo modo ignaro com que interpreta a attribuição, pela lei conferida a este Conselho, de resolver os casos omissos e as duvidas que se suscitarem na sua execução;

Resolvem os membros do Conselho Nacional do Trabalho, reunidos em sessão plena, desprezar os embargos, por falta de fundamento"226.

Em 6 de agosto de 1936, Eugenio D’Alessandro peticiona ao Ministro do Trabalho, Indústria e Comércio, renovando seu inconformismo e negando ser sindicalista:

"[É] verdade, fazia parte do Sindicato Centro dos Operarios Empregados Light, mas poucas vezes la compareci, e nunca occupei cargos sociaes" 227 .

Todavia, dos autos só consta um parecer do Consultor Jurídico interino pela rejeição, por ser a decisão em grau de embargos definitiva e por não se tratar de hipótese de avocatória ministerial.

\subsubsection{Da suspensão à aposentadoria}

\footnotetext{
${ }^{224}$ CNT, Processo n. 5.321/1935, fl. 20.

${ }^{225}$ Processo n. 5.321/1935, fl. 30.

${ }^{226}$ Processo n. 5.321/1935, fl. 48.

${ }^{227}$ Processo n. 5.321/1935, fl. 54.
} 
Já no processo de aposentadoria, em mais uma petição dirigida ao CNT, datada de 24 de abril de 1934, informa D’Alessandro a partida para a Inglaterra de seu chefe J. D. Murray, de modo a comprovar a vacância do posto na usina de reserva bem como a necessidade de um substituto qualificado; no caso, o próprio D'Alessandro ${ }^{228}$.

Com os autos em mãos, o $2^{\circ}$ Adjunto do Procurador Geral, Natércia da Silveira, pediu informações à empresa sobre a alegação de D’Alessandro, isto é, se seu posto originário seria o de maquinista. A curta resposta da Light, porém, afirma laconicamente o exercício em efetivo do cargo de assistência ao chefe.

Diante disso, a Procuradora emitiu emblemática manifestação:

\begin{abstract}
"Os motivos alegados pela Empreza são motivos de ordem technica, que não é possível contestar, uma vez que não ha como obter fundamento para isso.

A lei é esta; se dá lugar a abusos por parte das Emprezas, que della se venham a valer para afastar empregados, entretanto, nada é possível a este Conselho fazer. O remédio será reformar a lei.

$\mathrm{Na}$ sua vigencia, porém, o acto da Empreza não pode deixar de ser approvado",229.
\end{abstract}

Em seguida, o processo foi levado à pauta de julgamento. Por unanimidade, em 19 de outubro de 1934, o CNT anulou o ato de aposentadoria de Eugenio D’Alessandro. O acórdão é bastante exíguo, composto de relatório em um parágrafo acrescido de mais três de consideranda, mas confere interpretação ao parágrafo $5^{\circ}$ do artigo 53 do Decreto $n$. 21.081/1932:

"Considerando que não houve supressão de um serviço ou de um
departamento da Empresa, mas sim tentativa de extinção de um cargo,
com manifesta infracção da estabilidade funccional de um empregado
com 21 annos de effectivo serviço;
Considerando que, evidentemente, ao caso não tem aplicação o disposto
no citado p. $5^{\circ}$ do art. 53, o qual regula uma aposentadoria toda
excepcional, tanto assim que só póde ser applicado em se tratando de
funccionarios já dispensados, em virtude de suppressão do serviço ou
departamento onde trabalhavam, e nunca àquelles que ainda se encontram
no exercício do cargo;
Considerando que, aberto o precedente, teriam as Caixas de
Aposentadoria e Pensões de assumir a responsabilidade das Empresas,

${ }^{228}$ Processo n. 1.370/1934, fl. 96.

${ }^{229}$ Processo n. $1.370 / 1934$, fl. 104. 
quando estas não tivessem os meios legaes de dispensar os respectivos empregados com mais de 10 anos de serviço".

São três argumentos simples. O primeiro detecta e afasta a fraude ao regime da estabilidade decenal. O segundo coloca a aposentadoria prevista no parágrafo $5^{\circ}$ do artigo 53 no seu devido lugar, o da excepcionalidade, com limitação adicional quanto a empregados já dispensados em virtude da extinção do departamento ou do serviço respectivo. O terceiro é consequencialista, de proteção às finanças das Caixas, que eram constantemente esmiuçadas nas seções e departamentos do CNT.

D’Alessandro, entendendo-se vencedor, encaminha carta ao Presidente do CNT, em 18 de dezembro de 1934, dizendo-se não reintegrado, sem salário e sem aposentadoria.

A Light apresentara recurso de embargos apenas um dia antes, em 17 de dezembro de 1934. Voltava à carga com as razões referentes à extinção do serviço, pela "superveniência de novas invenções", acostando aos autos parecer técnico sobre o tema firmado pelo Chefe da Usina de Reserva, J. D. Murray.

Nas suas razões de contrariedade aos embargos, D'Alessandro repisa que "a palavra abalizada e autorizada (...) do Sr. J. D. Murray (...) deve ser mantida em quarentena", por se tratar de um seu desafeto.

Já em 15 de fevereiro de 1935, a Light requer sejam concedidas vistas do processo "ao Prof. Acebíades Delamare (...) afim de, em tempo, apresentar razões de contradicta às juntadas aos ditos autos pelo reclamante Eugenio D'Alessandro"230 ${ }^{\text {. A Light }}$ até então apresentava suas razões sempre por meio do Superintendente Bell, sem a participação de advogados, ao menos oficialmente nos autos. A intenção de apresentar "contestação da contestação"231, valendo-se do prestígio de Delamare, seja para procrastinar ou aditar os embargos outrora apresentados, foi detectada pela burocracia do CNT, mas não foi negada pelo presidente, que houve por bem conceder vistas de quarenta e oito horas em secretaria. A Light ofertou sua "contradicta", repetindo argumentos anteriores, em especial o da ausência do exercício do cargo efetivo de maquinista. A assinatura, no entanto, ainda é do Superintendente Bell. As mesmas vistas foram dadas ao reclamante, não resultando em novidades no processo. Mas, se havia intuito protelatório, esse intento foi alcançado, pois a apresentação de tais razões tomou mais de três meses.

${ }^{230}$ CNT, Processo n. 1.370/1934, fl. 152.

${ }^{231}$ CNT, Processo n. 1.370/1934, fl. 153. O próprio D’Alessandro, à fl. 157, afirmando ter sido informado por "companheiros fiéis e dedicados" sobre o pedido da Light, apressou-se em requerer vistas com o intuito de contrariar eventual manifestação por ela apresentada. 
Em nova análise do caso, a procuradora Natércia da Silveira altera seu entendimento, e passa a opinar pelo não acolhimento dos embargos, expondo que "o documento [parecer técnico de J. D. Murray] tem o vício de origem de ser emanado de um empregado da Empreza interessada"232.

O julgamento dos embargos manteve a decisão anterior de reintegração de D’Alessandro. O acórdão, publicado em 24 de julho de 1935, contém longo rol de consideranda, que servem de relatório e de suma da decisão tomada pelo Conselho Pleno.

A repercussão e a importância do caso levaram o Conselho Pleno a forjar uma "justa interpretação" 233 , de forma incidental ("preliminarmente"), para o parágrafo $5^{\circ}$ do artigo 53 do Decreto n. 21.081/1932:

"se deprehende ter sido estatuido pelo legislador um regimen excepcional, sendo que a aposentadoria nelle prevista só se coaduna com a suppressão de 'serviço' ou de 'departamento' pelo desaparecimento do seu objecto ou pela superveniência de novas invenções, hypothese esta em que, de modo algum, fosse possivel o aproveitamento dos empregados na mesma empreza, em funcções de remuneração e categoria equivalentes.

(...) as expressões 'o serviço' e 'o departamento' no p. $5^{\circ}$ do citado art. 53 , separadas pela disjunctiva 'ou' são, logicamente, referidas ao outro termo da oração -- 'das emprezas', e, por tal forma, ha de se entender, forçosamente, que é 'o serviço das emprezas' ou 'o departamento das emprezas' de que se cogita no texto legal e não de uma funcção individual.

(...) no caso em exame, 'o serviço' da empreza é a producção e distribuição de energia electrica, continuando a operar o respectivo departamento, ou secção de departamento -- Usina Thermica de Reserva (fl. 132) por força, aliaz, do contracto de concessão.

(...) aceita a doutrina proposta seria subverter, por completo, o espirito $d a$ lei, admittindo-se a aposentadoria por suppressão do cargo, o que implantaria, definitivamente, a derrocada do regimen da estabilidade funccional.

(...) consentida a hypothese alvitrada pela embargante, fracassariam, fatalmente, as instituições de previdencia social, as quaes arcariam com os elementos que as emprezas pretendessem dispensar, concorrendo, outrossim, innumeras possibilidades de fraudes contra as mesmas instituições, as quaes, de ordem e utilidade publica e de tão grande relevancia social, cumpre a este Conselho, como finalidade propria e precipua defender (...)".

A interpretação dada ao dispositivo é uma mistura de análise gramatical, consequencialismo e enunciação de palavras para além do texto legal, com o espírito da lei e a vontade do legislador, elementos característicos do "novo direito".

${ }^{232}$ CNT, Processo n. 1.370/1934, fl. 183.

${ }^{233}$ CNT, Processo n. 1.370/1934, fl. 202. 
O conselheiro Paranhos Fontenelle ofertou longo e áspero voto divergente, pelo qual acolhe os embargos da Light. Invocou argumentos de ordem processual, tais como a mudança do entendimento reiterado do CNT a respeito do tema bem como a incompetência da $2^{\text {a }}$ Câmara do CNT para "intervir, como interveio, em favor de um denunciante, para quem a faculdade do p. $1^{\circ}$ do art. 51 , citado ${ }^{234}$, ainda estava adormecida ou latente, de vez que não havia decisão da Junta Administrativa" ${ }^{\text {235. }}$.

Prossegue afirmando que a $2^{\text {a }}$ Câmara "transpoz a lei", pois deveria ter se quedado inerte:

"Tomando a iniciativa de exigir o processo de E. D’Alessandro da Caixa
de Aposentadoria e Pensões da Comp. Light \& Power, como si já
houvesse o objecto da reclamação ou a lesão de direito a reclamar, a $2^{\mathrm{a}}$
Câmara arrogou-se a falsa 'competencia assessoria' que o Conselho lhe
negou (...) contra o princípio de escolástica -- Natura non facet saltus --
para intervir extra officio".

Defendeu também que não se tratava de julgar se à Light assistia o direito de requerer a aposentadoria de D'Alessandro, uma vez que “o acto [aposentadoria] é deferido, por lei, ao empregado dispensado" 236 e é facultado à Light exercer "o poder de dispensar empregados, embora validos, mas tornados inuteis" 237 .

O apelo de Paranhos Fontenelle à interpretação gramatical é veemente:

“Ora, essa excepção é declarada pela negativa: 'P. $5^{\circ}$ (art. 53 do Dec.
21.081). Não se comprehendem igualmente neste artigo so empregados
que se tenham tornado desnecessarios por ter sido supprimido o serviço
ou o departamento das empresas em que trabalhavam, em virtude de ter
desaparecido o seu objecto ou pela superveniencia de novas invenções'.
Si não se comprehendem neste artigo 53; si não se comprhendem na
sanção de que 'só poderão ser demittidos', é claro, clarissimo mesmo,
grammatical e juridicamente, que 'os empregados que se tenham tornado
desnecessarios por ter sido supprimido o serviço, em virtude de ter
desapparecido o seu objecto', podem ser demittidos pela Companhia,
queira ou não queira a Camara, porque não seria esta a tutora das
empresas para admittir ou demittir os seus empregados, nem o technico,

${ }^{234}$ Decreto n. 20.465, de 31 de dezembro de 1931. Art. 51. Quando o presidente das juntas administrativas ou outro dos seus membros não se conformar com qualquer resolução da maioria, poderá recorrer para o Conselho Nacional do Trabalho, no prazo de 10 dias, contados da data da decisão. $\S 1^{\circ}$ Ao empregado ou ao membro de sua família que se não conformar com as decisões das juntas administrativas, nos casos em que for interessado, será igualmente facultado recorrer para o Conselho Nacional do Trabalho, dentro do prazo de 30 dias, contados da data da sua notificação, em carta registrada, para o local do seu domicílio.

${ }^{235}$ CNT, Processo n. 1.370/1934, fl. 204.

${ }^{236}$ CNT, Processo n. 1.370/1934, fl. 205.

${ }^{237}$ CNT, Processo n. 1.370/1934, fl. 205. 
na exploração do serviço publico, de cuja exactidão, para com esse publico que paga, são fiscaes competentes outras repartições.

Mas o artigo de lei não se interpreta sinão à luz da razão e por hermeneutica segura, que tem de retroceder até a origem da lei, declinada ad extremum e nunca ad initium, lei completa, sem a mutilação de seus complementos intelligiveis, para applical-a, integral, aos empregados 'dispensados em virtude de ter desaparecido o objecto do serviço, mas não differenciada, posta de abreviação manifesta sobre os funcionarios que se dizem ainda no exercicio de cargo supprimido" 238 .

Dessa forma, Paranhos Fontenelle chega a uma diferenciação entre dois regimes, o da "estabilidade funccional" e o da "garantia" em caso de dispensa:

"Bastava ver que a estabilidade funccional, de que vieram a cogitar as Camaras, depois de 14 de agosto de 1934 (Art. 13 do Dec. $24.784^{239}$ ) é bem differente da garantia que, vencida aquella, assegura a lei, então, aos empregados demitidos, por falta grave e aos dispensados, por desnecessarios, e que essa garantia se acha definida pela faculdade de continuarem como associados da Caixa, no primeiro caso, e o direito de se aposentarem, na segunda hypothese" 240 .

O voto ainda mira a manifestação da Procuradoria:

"Impugnar à empreza a prova de que a desnecessidade do serviço deve ser offerecida pelos seus technicos e responsaveis, é impugnar a opinião do ajudado quando declara que o seu ajudante não lhe presta auxilio. Si amanhã este Conselho desejasse saber si o Adjunto de procurador é necessario à Procuradoria, não iria indagar do Consultor da Republica, porque sua autoridade não the daria a observação funccional que tem $o$ procurador local para responder em causa propria ${ }^{241}$.

Fontenelle também aponta que D'Alessandro, por falta de habilitação para exercer a função de engenheiro, jamais poderia ter substituído a chefia da Usina Térmica de Reserva e ataca, por entender ser de má-fé, sua negativa de receber a indenização ofertada pela Light bem como sua pretensão de reversão ao cargo originário de maquinista:

"Seria esse o argumento [ausência de habilitação pra o exercício da engenharia] para desencantar a ingenuidade daqueles que começavam a

\footnotetext{
${ }^{238}$ CNT, Processo n. 1.370/1934, fls. 205-6.

239 Artigo 13. Compete às Camaras julgar as reclamações contra actos das Caixas e Institutos de Aposentadoria e Pensões e das empresas e estabelecimentos a umas e outros ligados, no tocante á estabilidade e outras garantias asseguradas por lei aos respectivos empregados, e, bem assim, os recursos interpostos ex-officio pelas juntas e conselhos administrativos, das suas decisões, e pelos terceiros a que ellas affectem.

${ }^{240}$ CNT, Processo n. 1.370/1934, fl. 206.

${ }^{241}$ CNT, Processo n. 1.370/1934, fl. 207.
} 
acreditar no espírito de renuncia do denunciante -- que não quer ser assistente, com 1:200\$000 mensaes, mas sim um simples machinista (fls. 180) com ordenado especial, maior, em todo o caso que o do chefe actual da Uzina, seu superior hierarchico"242.

Por fim, paradoxalmente, a divergência se encerra com uma citação do juslaboralista argentino, agraciado com o Prêmio Nobel, Carlos Saavedra Lamas ${ }^{243}$, bem como com a invocação da equidade:

\begin{abstract}
"E no final de tudo, reconhecer que a aposentadoria desapparece, contra o espirito da excepção, diante da dispensa do empregado; que o direito do funccionario, na justiça neo-social da Camara, sobrevive à funcção extincta; e que a faculdade legitima ainda ha bem pouco tempo declarada pela Lei n. 62 de 5 de junho do corrente anno (diario oficial de 11 de junho de 1935) que tem os empregadores de despedir os empregados, por causa justa e força maior, em que se inclue a suppressão do emprego ou cargo, aconselhada pelas condições economicas desses empregados (p. $1^{\circ}$ do Artigo $4^{\circ}$ da Lei citada) não é tão respeitavel como as tradições de um direito que, tanto na Russia como em nosso paiz, segundo recorda Saavedra Lamas no seu projecto de Codigo do Trabalho (paginas 78 e 81 do Tomo primeiro) velam pela equidade da lei" ${ }^{244}$.
\end{abstract}

Em 02 de setembro de 1935, D’Alessandro apresenta nova petição informando a recalcitrância da Light em reintegrá-lo e, portanto, cumprir o acórdão. Ocorre que a Light, não se dando por vencida, interpusera recurso hierárquico ao Ministro do Trabalho, Indústria e Comércio. $\mathrm{O}$ apelo foi liminarmente rejeitado, por ausência de previsão legal e regimental.

Só em 20 de março de 1936 a Light é intimada pelo CNT a dar cumprimento ao decidido. Sem sucesso, e provocado por D’Alessandro, o Conselho Pleno decide aplicar à Light "multa de 50\$000 (cincoenta mil réis) diarios até o integral cumprimento do accordão proferido" ${ }^{245}$. A multa pela recalcitrância no cumprimento da decisão do CNT foi

\footnotetext{
${ }^{242}$ CNT, Processo n. 1.370/1934, fl. 208.

${ }^{243}$ Carlos Saavedra Lamas foi Ministro das Relações Exteriores da Argentina de 1932 a 1938, durante a presidência do General Agustín Justo, quando presidiu a Conferência de Paz Del Chaco, da qual participaram Brasil, Chile, Peru, Uruguai e Estados Unidos, alcançando-se um acordo de armistício em 12 de junho de 1935 que colocou fim à Guerra do Chaco (1932-1935). Por isso, foi agraciado com o Nobel da Paz em 1936. Foi presidente da XI Conferência Internacional do Trabalho, celebrada em Genebra em 1928, da Conferência Panamericana de 1936 e da Assembléia da Sociedade das Nações em 1936. Era membro do laicato católico argentino. Sua proposta de Código do Trabalho para a Argentina serviu de material doutrinário em toda a América Latina nos anos 1930 e 1940 . Cf. http://www.dec.ufcg.edu.br/biografias/NPCSLama.html. Acesso em 13 out 2012.

${ }^{244}$ CNT, Processo n. 1.370/1934, fls. 208-9.

${ }^{245}$ CNT, Processo n. 1.370/1934, fl. 239.
} 
paga apenas em 13 de janeiro de 1942, diante da movimentação da Procuradoria no sentido da execução ${ }^{246}$.

Em seguida, D’Alessandro deixa de atuar em causa própria e constitui seu patrono o advogado Joaquim Rodrigues Neves, que viria a ser presidente da Ordem dos Advogados da Capital em $1941^{247}$. Rodrigues Neves faz pedido inusitado para quem havia sido constituído nos autos para levar a Light ao cumprimento da decisão: peticiona requerendo que a Procuradoria dê seguimento à execução da decisão do CNT favorável ao seu cliente.

Não há nos autos manifestação da Procuradoria a respeito do requerido, mas há um processo em apenso ${ }^{248}$, no qual foi extraída a carta de sentença que possibilitou a D’Alessandro promover a execução perante a Justiça Federal onde, em 12 de dezembro de 1940, a Light pagou-lhe "ordenados vencidos e efetuou a reintegração simbólica"249.

A simples extração da carta de sentença, no entanto, não foi tarefa fácil. Diante da demora do CNT, D’Alessandro recorreu à intercessão de Pedro Mazolleni que, à sua vez, foi ao Padre Arruda Câmara.

Pedro Teixeira Mazolleni, que já tivera contato com D’Alessandro na DESPS, era Primeiro Sargento da Polícia Militar do Distrito Federal e foi excluído de suas fileiras em 1925, acusado de crime político de conspiração, pelo envolvimento em "movimentos revolucionários" durante o governo Artur Bernardes. Em 1927 foi reincluído na corporação, mediante renúncia à percepção dos vencimentos do período de afastamento ${ }^{250}$. Já em 1930 sua sorte mudaria. Primeiramente, foi contemplado pelo Decreto n. 19.395, de 8 de novembro, que anistiou todos os civis e militares envolvidos em movimentos

\footnotetext{
${ }^{246}$ CNT, Processo n. 1.370/1934, fl. 275.

${ }^{247}$ Rodrigues Neves foi Grão Mestre do Grande Oriente do Brasil, tronco originário da maçonaria no Brasil. Defensor de uma linha tradicional para a entidade, provocou a cisão dos anos 1940. Esta ruptura é contada em detalhes no livro A tragédia da piedade: mentiras e calúnias da "A vida dramática de Euclides da Cunha" (Rio de Janeiro: Edições O Cruzeiro, 1951), escrito pelo também membro da maçonaria Dilermando de Assis, após o cumprimento da pena pelo assassinato de Euclides da Cunha. O livro é um misto de libelo de autodefesa, autobiografia, crítica de Os Sertões e resposta ao livro A Vida Dramática de Euclides da Cunha (PONTES, Eloi. Rio de Janeiro: José Olímpio, 1838).

${ }^{248}$ CNT, Processo n. $16.313 / 36$.

${ }^{249}$ CNT, Processo n. 1.370/1934, fl. 272.

${ }^{250}$ BRASIL. AGU. Parecer do Consultor Geral da República Francisco Campos a pedido do Ministério da Fazenda (Aviso n. 240, de 21 de outubro de 1935). Exarado em 07 de janeiro de 1936. Ementa: ASSUNTO: Pagamento de vencimentos atrasados a Pedro Teixeira Mazolleni, $1^{\circ}$ tenente da Polícia Militar do Distrito Federal. Disponível em: http://www.agu.gov.br/sistemas/site/PaginasInternas/NormasInternas/AtoDetalhado. aspx?idAto=2826. Acesso em: 18 out 2011. A expressão "movimentos revolucionários" é do Consultor. É possível que Mazolleni tenha se envolvido com o movimento tenentista, que empreendeu ativa oposição a Artur Bernardes. Por isso a mudança de sorte de Mazolleni do pós-1930, uma vez que os tenentes apoiaram Getúlio.
} 
revolucionários até então ${ }^{251}$. Seria a partir daí agraciado com promoções na corporação ${ }^{252} \mathrm{e}$ até um cargo de interventor na Sociedade Civil Mantenedora da Guarda do Caes do Porto do Rio de Janeiro ${ }^{253}$.

Ao final do ano de 1936, Eugenio D’Alessandro recorre aos préstimos de Mazolleni. Este envia uma carta ao Padre Arruda Câmara, à época Vice-presidente da Câmara dos Deputados e "Benemérito das Polícias Militares do Brasil". Na carta, Mazolleni apresenta-o como “humilde, mas honrado cidadão Eugenio D’Alessandro, victima do capricho do "polvo canadense",254.

A Light ${ }^{255}$ foi apresentada por meio da alcunha popularmente utilizada para a ela se referir. $\mathrm{O}$ apelido era de fato representativo do que era a multinacional Light para o capitalismo brasileiro. A empresa chegou a São Paulo em 1899 e no Rio de Janeiro em 1904, passando a atuar, ao longo dos anos, nos ramos de geração, transmissão e distribuição de energia hidrelétrica e termoelétrica, bem como transportes urbanos por bondes e tramways (espécie de ônibus elétrico), em muitos casos em regime de monopólio. A presença do grupo canadense no cotidiano nacional era tão intensa que o termo light se tornou sinônimo de eletricidade na linguagem oral local. A chegada da Light a São Paulo foi assim descrita, a partir de documento interno da empresa:

"Às primeiras horas da madrugada do dia 7 de maio de 1900, um som
inusitado ecoou pelas estreitas ruas de São Paulo. Da rua Barão de
Limeira em direção ao largo de São Bento, pequena praça no centro da
então segunda maior cidade do Brasil, vinha um ruidoso bonde elétrico,
de laterais abertas, uma lanterna à frente, rompendo a escuridão.
Enquanto isso, cidadãos curiosos pulavam da cama para apreciar,
amontoados nas calçadas, o espetáculo que se descortinava. N, o controle
das alavancas estava Robert Calthrop Brown, engenheiro americano de
35 anos que havia pouco mais de um ano fora gerente da companhia de
bondes da distante Halifax, na Nova Escócia. Brown se aventurara a
fazer, à lh da manhã, uma inspeção surpresa de última hora na linha

${ }^{251}$ O p. $1^{\circ}$ do artigo $1^{\circ}$ do decreto assim dispunha: "Ficam em perpétuo silêncio, como se nunca tivessem existido, os processos e sentenças relativos a esses mesmos fatos e aos delitos políticos de imprensa".

${ }^{252}$ Para a promoção a Primeiro Tenente, cf. DOU de 26 de julho de 1933, p. 14.811. Para a promoção a Tenente-coronel, cf. DOU de 21 de dezembro de 1943, p. 18.724.

${ }^{253}$ Para a nomeação ao cargo de interventor, cf. DOU de 16 de abril de 1936, pp. 8.082-3.

${ }^{254}$ CNT, Processo n. 16.313/1936, fl. 3.

${ }^{255}$ Para as informações aqui trazidas sobre a Light, cf. WEID, Elisabeth von der. A expansão da Rio de Janeiro Tramway Light and Power ou as origens do "Polvo Canadense". Fundação Casa de Rui Barbosa, Rio de Janeiro. Disponível em: http://www. casaruibarbosa. gov.br/ dados/ DOC/ artigos/o-z/ FCRB_Elisabethvonder Weid_Expansao_RiodeJaneiro_TramwayLightandPower.pdf. Acesso em: 27 out 2012; MACDOWALL, Duncan. Light: a história da empresa que modernizou o Brasil. Rio de Janeiro: Ediouro, 2008; e, SAES, Alexandre Macchione. Conflitos do capital: Light versus CBEE na formação do capitalismo brasileiro (1898-1927). Campinas, 2008. 428 p. Dissertação de Doutorado - Instituto de Economia, Universidade de Campinas. Disponível em: http://www. bibliotecadigital. unicamp.br/ document/ ?code $=$ vtls000446813\&fd=y. Acesso em: 28 out 2012. 
recém-concluída, a ser inaugurada mais tarde, ainda naquele dia. $\mathrm{O}$ bonde elétrico que conduzia (um bonde com nove bancos, chassis e carroceria Brill e motor General Electric) fora construído na América do Norte e era o primeiro a circular na próspera cidade, em franca expansão, com 240 mil habitantes. Após um percurso sem problemas, Brown inverteu o bonde e trouxe-o de volta à garagem, na Rua Barão de Limeira, seguro de que tudo estava pronto para a festividade daquele dia. Acima dos portões da garagem de bondes um letreiro indicava a propriedade da nova empresa. A São Paulo Tramway, Light and Power Company Limited, incorporada segundo as leis de Ontário, com escritório central em Toronto, viera fazer negócios no Brasil’256.

A Light ampliaria rapidamente seus investimentos no Brasil, passando a atuar em diversas capitais, após obter sucesso na formação de uma base de sustentação dos negócios logo no início do século XX. O polvo espraiaria seus tentáculos por todo o Brasil:

"As empresas do Grupo Light, e os empresários norte-americanos que as
organizaram, chegaram no Brasil através de São Paulo. Os capitalistas
estrangeiros vieram atender a uma proposta de concessionários locais de
linhas de transporte ferro-carris por tração elétrica, que procuravam
capital para desenvolver sua concessão e o encontraram no Canadá.
William Mackenzie, capitalista ligado a empresas de estradas-de-ferro e
seguros, reuniu-se a outros empresários canadenses e formaram em seu
país uma companhia para desenvolver o projeto de carris eletrificados na
pequena cidade ao sul do Equador.
Em pouco tempo, os canadenses estabeleceram relações estreitas com
políticos influentes e obtiveram autorização para produzir e distribuir
energia hidroelétrica, que era essencial para levar a bom termo o projeto.
A São Paulo Tramway Light and Power Co. Ltd. foi autorizada a
funcionar no Brasil em julho de 1899, e em seguida obtinha a
transferência da concessão para a exploração de transportes ferro-carris
por tração elétrica.
Em pouco tempo, os empresários da São Paulo Light desenvolveram uma
campanha de concorrência e influências políticas que levou à unificação
dos contratos de transportes urbanos em 1901 e, neste mesmo ano, à
absorção por compra de ações da Companhia Água e Luz de São Paulo.
Estas duas áreas deram à empresa canadense uma base suficiente para
concorrer com as outras companhias que estivessem no seu caminho, ou
absorve-las"257.

A carta de Mazolleni buscava contrapor o constante trânsito da Light entre autoridades federais e municipais, com quem tinha que se entender para o bom andamento de seus negócios no Brasil, uma vez que à União cabia a regulamentação dos serviços e os

\footnotetext{
${ }^{256}$ MACDOWALL, Duncan. Light: a história da empresa que modernizou o Brasil. Rio de Janeiro: Ediouro, 2008, p. 25 .

${ }^{257}$ WEID, Elisabeth von der. A expansão da Rio de Janeiro Tramway Light and Power ou as origens do "Polvo Canadense". Fundação Casa de Rui Barbosa, Rio de Janeiro. Disponível em: http://www. casaruibarbosa. gov.br/ dados/ DOC/ artigos/o-z/ FCRB_Elisabethvonder Weid_Expansao _RiodeJaneiro_TramwayLightandPower.pdf. Acesso em: 27 out 2012.
} 
Municípios funcionavam como poderes concedentes. Mazolleni pede que o Padre Arruda Câmara ajude D'Alessandro no intento de fazer a Light cumprir a decisão do CNT:

\begin{abstract}
"Consoante n/ palestra, ha tempos, em companhia do Cap. Peres, envio a V. Ex., por copia, os accordãos do Conselho Nacional do Trabalho que dizem respeito ao caso do humilde, mas honrado cidadão Eugenio D'Alessandro, victima do capricho do 'polvo canadense'.

Rodo, data venia, a attenção, a brilhante inteligencia e a generosidade de V. Ex., como brasileiro, sacerdote, cultor das letras juridicas e sub-chefe do Legislativo Nacional, para o desrespeito às decisões das autoridade brasileira e para a angustiosa situação do proletario que vê o s/ direito esbulhado, quando impera a vontade caprichosa do empregador, apezar de todo o esforço do governo na feitura das leis de assistencia aos trabalhadores.

No caso em apreço, que é de annullação de aposentadoria, poderia a legislação cuidar, previdentemente, de multa maior, devendo uma parte correspondente aos vencimentos (de aposentado) caber ao aposentando, armando-o, assim, de recursos financeiros $\mathrm{p} /$ manter a propria subsistencia e a da familia, enquanto se processava a discussão em torno do capricho da empreza." ${ }^{258}$.
\end{abstract}

Com a carta, Mazolleni encaminhou cópias das decisões do CNT bem como dos respectivos registros de publicação em diário oficial.

O apelo ao Padre Arruda Câmara se explica pelo apoio deste aos movimentos de anistia do pós-Revolução de 1930, em especial à anistia geral da Constituição de 1934 (artigo 119) ${ }^{259}$, que beneficiou Mazolleni. Arruda Câmara, que fora deputado constituinte em 1934, era também próximo do Ministro Agamenon Magalhães ${ }^{260}$ e antes já houvera

${ }^{258}$ CNT, Processo n. 16.313/26, fl. 3.

259 SILVA, Sandro Héverton Câmara da Silva. Anistia polítca: conflito e conciliação no âmbito do Congresso Nacional Brasileiro (1964-1979). Rio de Janeiro, 2007, 155 p. Dissertação de Mestrado - Instituto de Filosofia e Ciências Humanas, Universidade do Estado do Rio de Janeiro. Disponível em: http://bd. camara.gov.br/bd/handle/bdcamara/3663. Acesso em: 18 out 2012.

260 José do Rego Maciel, advogado e político Pernambucano, pai do ex-vice-presidente Marco Maciel, confirma a ligação de ambos. Cf. MACIEL, José do Rego. José do Rego Maciel (depoimento a Dulce Chaves Pandolfi, 1976). Rio de Janeiro, CPDOC, 1992. 28 p. dat. Disponível em: http://www.fgv.br/cpdoc/historal/arq/Entrevista155.pdf. Acesso em: 27 out 2012. "D.P. - E quem era a liderança do PDC? J.M. - Padre Arruda Câmara. Padre Arruda Câmara exerceu uma liderança incontestável no partido dele, era um homem que tinha muitas qualidades de líder e era um homem combativo, muito combativo. D.P. - O Padre Arruda Câmara foi ligado ao Agamenon? J.M. - Durante o Estado Novo ele mantinha boas relações com o Agamenon. Depois houve divergências, porque na candidatura Barbosa Lima, Padre Câmara ficou com Neto Campelo, e o PSD lançou Barbosa Lima. Porque aí, logo depois, em 46, houve uma dissidência muito grave no PSD com a divergência de Novais Filho. Ele saiu do partido e levou com ele Neto Campelo. Neto Campelo era uma pessoa muito amiga dele, não tinha a projeção que tinha o Novais Filho, mas Neto Campelo conseguiu ser ministro da Agricultura no governo Dutra. Acho que foi indicação até do Novais, porque ele era senador nessa época. Depois, quando se falou em sucessão em Pernambuco, Agamenon tinha um candidato já lançado antes, muito antes de haver eleição para a Assembléia Constituinte, e havia sido lançada pelo PSD a candidatura de Barbosa Lima Sobrinho [inaudível], e aí Agamenon manteve a candidatura. E foi justamente por isto, porque o Novais achava que devia haver um reexame da situação, porque havia a Constituição, havia isso, aquilo outro... Aí o Agamenon disse: 'Não, a candidatura está 
flertado com o integralismo ${ }^{261}$. Foi ainda um dos fundadores do Partido Democrata Cristão, pelo qual se elegeu constituinte de 1946 e deputado federal.

O Padre Arruda Câmara deu seguimento ao pedido e encaminhou a carta ao Ministro do Trabalho, Indústria e Comércio, Agamenon Magalhães ${ }^{262}$. Este, à sua vez, pediu explicações ao Presidente do CNT, que logo solicitou parecer da Procuradoria do órgão.

Em 10 de fevereiro de 1937, o Procurador Geral emite o parecer, afirmando que o CNT encerrara sua atuação, que caberia a D’Alessandro extrair a carta de sentença e prosseguir na execução do julgado. Agamenon Magalhães não se manifesta sobre o mérito do pedido e apenas pede que seja comunicado o teor do parecer a D'Alessandro. Este peticiona pela extração da carta de sentença em 11 de janeiro de 1937. Apenas em 22 de julho de 1937 a carta de sentença, consistente em narrativa datilografada sobre as manifestações e decisões constantes dos autos, é franqueada a D’Alessandro.

\subsubsection{A Light volta à carga}

mantida.' Ele, aí, divergiu e lançou, nessa época, Neto Campelo, que contou com o apoio da UDN. A UDN veio toda, e veio o Padre Câmara."

${ }^{261}$ Guilherme Figueiredo, dramaturgo e irmão do último presidente militar do Brasil João Batista Figueiredo, confirma a ligação do Padre Arrruda Câmara com os integralistas. Cf. FIGUEIREDO, Guilherme. Guilherme Figueiredo (depoimento a Rosa Maria Barbosa de Araújo, 1977). Rio de Janeiro, CPDOC. Disponível em: http://www.fgv.br/cpdoc/historal/arq/Entrevista107.pdf. Acesso em: 27 out 2012. "Agora, no Exército, o negócio marcou mais. Esses tenentezinhos ficaram empolgados com o integralismo e mesmo depois continuaram com idéias integralistas. Muitos deles são hoje generais e, por isso, por causa do integralismo, estão pensando o que não devem. Uma coisa terrível. E outros, os mais habilidosos, eram sujeitos apenas inteligentes e ambiciosos, que queriam ter uma participação no poder público e, até mesmo generosamente, queriam contribuir para alguma coisa que achavam que deviam fazer. Então aderiam ao integralismo, porque era o que estava mais próximo do poder. Eles se infiltravam e eram excelentes oficiais de gabinete, sujeitos que sabiam redigir coisas. Eram o San Thiago Dantas, o padre Arruda Câmara, o Jeová Mota. Muitos, depois, quando viram que não era mais possível chegar ao poder pelo integralismo, vieram para o outro lado e passaram a ser de esquerda. O Martins Moreira vira para esquerda, o nosso dom Hélder Câmara vira para a esquerda, o Jeová Mota, e aquele professor de grego, coitado, o Álvaro Moreira. Não é o Álvaro Moreira escritor. É um outro que escreveu uma tese sobre o conceito de energia em Platão, uma tese enorme. Está aí, coitado, exilado. Fui visitá-lo. Esse coitado foi integralista na hora errada e foi comunista na hora errada; apanhou sempre. [risos]"

${ }^{262}$ Agamenon Magalhães ocupou a chefia do Ministério do Trabalho de julho de 1934 a novembro de 1937. Sua base política era Pernambuco e conhecia bem as questões trabalhistas. Decidido a fazer política, delegou todas as atividades burocrático-administrativas do ministério. Estimulou a criação de um sem número de sindicatos de fachada, sem existência real, destinados apenas a ter delegados-eleitores que escolheriam deputados classistas. Ao mesmo tempo ordenou invasões de sindicatos atuantes e oficialmente reconhecidos, "reais", capitaneados por lideranças de esquerda, que faziam greves, mesmo antes da promulgação de Lei de Segurança Nacional de 1935. Cf. GOMES, Angela de Castro. A invenção do trabalhismo. $3^{a}$ ed. Rio de Janeiro: Editora FGV, 2005, p. 176. 
Se é certo que D’Alessandro foi reintegrado aos quadros da Light em 12 de dezembro de 1940, também é certo que a Light não desistiu de seus intentos após esse ato. E nem D'Alessandro deixou de recorrer ao CNT e ao Ministério.

Em 23 de março de 1943, D’Alessandro enviou uma carta ao Ministro Alexandre Marcondes Filho relatando os percalços distribuídos pelos dez anos anteriores. Relata ainda que, ao ser reintegrado a seu posto de trabalho na usina de reserva, descobriu que os demais trabalhadores da mesma função haviam recebido sucessivos aumentos salariais, que lhe estavam sendo negados. Daí nasceu novo processo perante a $4^{\text {a }}$ Junta de Conciliação e Julgamento da Capital, pela "egualdade de salários" ${ }^{263}$. Do processo iniciado

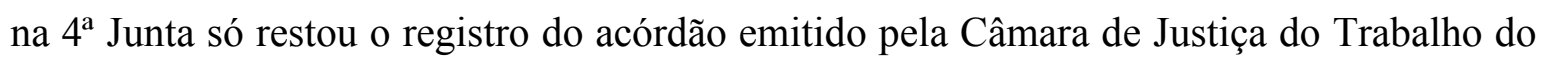
CNT, em grau de recurso extraordinário, em 9 de junho de 1943, cuja cópia consta dos autos do próprio autuado que contém a carta de D’Alessandro ao Ministro Marcondes Filho $^{264}$. O preenchimento do campo "assunto", constante da capa dos autos, já indica que os dias de Eugenio D’Alessandro após a reintegração não foram de paz:

“Eugenio D'Alessandro apela para o Snr. Ministro, para que mande investigar 'in loco' a sua situação como empregado da 'Light and Power'.",265

D’Alessandro pede ao Ministro que envie um seu representante para ouvi-lo nas dependências da Light, uma vez que, após a reclamação da diferença salarial, já tinha sido chamado a comparecer à delegacia de polícia em quatro oportunidades, acusado de "prática de atos de sabotagem"266. Ainda assim relata que nenhuma arbitrariedade lhe havia sido imposta até então e faz elogios ao coronel Etchegoyen.

Alcides Gonçalves Etchegoyen substituiu Filinto Muller na chefia de polícia do Distrito Federal em 1942. Permanecendo no cargo de chefe de polícia até 31 de agosto de 1943, quando se demitiu de suas funções. Combateu o jogo do bicho e a prostituição ${ }^{267}$, além de perseguir as atividades políticas de oposição ao governo, como seu antecessor.

\footnotetext{
${ }^{263}$ O processo não foi localizado durante o trabalho de pesquisa. Não há registro de sua preservação no Tribunal Regional da $1^{\text {a }}$ Região nem no TST. O próprio D’Alessandro, na carta enviada ao Ministro Marcondes Filho, informa que no bojo do processo da isonomia salarial pendia de análise um recurso extraordinário. Também deste processo não há registro.

${ }^{264} \mathrm{O}$ acórdão garantiu a D’Alessandro a percepção do mesmo salário que os demais trabalhadores da mesma função, bem como ordenou o pagamento das diferenças desde a reintegração. Cf. Processo n. 7.278/1943, fls. 24-5.

${ }^{265}$ CNT, Processo n. 7.278/1943.

${ }^{266}$ CNT, Processo n. 7.278/1943, fl. 35.

${ }^{267}$ Cf. TÉRCIO, Jason. A espada e a balança: crime e política no banco dos réus. São Paulo: Jorge Zahar Editor, 2002, p. 188.
} 
Antes, liderou a chamada Coluna Relâmpago que, em 1926, tentou promover um levante com a finalidade de impedir a posse de Washington Luís, eleito presidente da República. Em 1930, combateu pela revolução no Rio Grande do Sul, participando do comando revolucionário. Anistiado em novembro daquele ano, foi nomeado delegado militar revolucionário junto à $3^{\mathrm{a}}$ Região Militar, devido à sua intransigente defesa dos princípios que nortearam a Revolução de 1930. Promovido a major em 1933, Etchegoyen serviu como oficial-de-gabinete do ministro da Guerra, Eurico Gaspar Dutra, de dezembro de 1936 a maio de 1938. Nos anos seguintes foi agraciado com outras promoções na hierarquia militar, chegando a general de brigada e à Escola Superior de Guerra ${ }^{268}$.

Ao pedido desesperado direcionado ao Ministro Marcondes Filho, pendente de análise em meio à morosidade dos andamentos e prolixidade da burocracia do CNT, seguiu-se um grave comunicado enviado ao Conselho pelo Superintendente Geral da Light J. G. de Aragão, que alteraria novamente a sorte do D'Alessandro:

"Em data de 2 do corrente [julho de 1943], recebi o ofício reservado n.
3294, datado de 30 do mês p.p., pelo qual o Sr. Delegado Especial de
Segurança Política e Social, da Polícia do Distrito Federal, 'propoz o
afastamento imediato de Eugenio D'Alessandro das funções do emprego
que exerce nesta Companhia por se tratar de elemento cuja suspeição do
ponto de vista político-social ficou suficientemente esclarecida' através
das sindicâncias procedidas por aquela Delegacia Especial.
Comunico a V. Exa., para os devidos efeitos, que, em consequência,
expedi as ordens necessárias para que fosse, sem demora, adotada a
providência proposta pelo Sr. Coronel Delegado de Segurança Política e
Social, por motivo relevante de ordem pública."

O comunicado logo subiu à consideração do presidente do CNT, Filinto Muller, o antecessor de Etchegoyen na chefia da polícia política varguista. Surpreendentemente, Filinto Muller ordenou que os autos do processo da isonomia salarial baixassem à execução, pois a "comunicação de fls. não tem força para sustar a execução de um julgado de Câmara competente"269. O inquérito da DESPS, embora sem ter apurado qualquer crime praticado por D’Alessandro, serviu para afastá-lo da Light.

O processo daí seguiu ao Consultor Geral para a emissão de parecer sobre o pedido de vistoria in loco de D'Alessandro. O parecer sugeriu o indeferimento, por se

${ }^{268}$ Cf. FGV. CPDOC. Dicionário Histórico Biográfico Brasileiro: verbete Alcides Etchegoyen. Rio de Janeiro, 2010. Disponível em: http://cpdoc. fgv.br/ producao/ dossies/ AEraVargas2/ biografias/ alcides_etchegoyen. Acesso em: 29 de outubro de 2012.

${ }^{269} \mathrm{CNT}$, Processo n. 7.278/1943, fl. 23 e verso. 
tratar de "medidas policiais (...) estranhas às atribuições deste Ministério". Contudo, ainda consignou que "cabe enviá-la [carta de D’Alessandro] ao Sr. Ministro da Justiça"270.

Em mais uma carta a Marcondes Filho, D’Alessandro se declara "satisfeito com o desfecho desse caso ruidoso e tumultuoso em que o minúsculo David abateu o

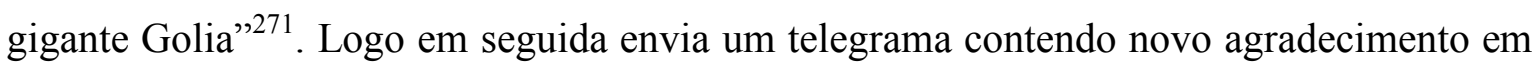
meio a laudas a Vargas e ao próprio Ministro, que motivou um telegrama de resposta:

“Agradeço referências feitas em seu telegrama 16 abril findo à minha palestra na Hora do Brasil em homenagem data aniversário natalício preclaro Presidente Getulio Vargas pt Saudações.”

Alexandre Marcondes Filho, com suas palestras radiofônicas, foi responsável por um crescimento do apoio popular a Vargas quando de sua gestão como Ministro. Marcondes ia frequentemente às rádios falar sobre a legislação trabalhista. Sempre se valendo de vocabulário amigável, ressaltava seus benefícios e os meios para dela se valer $^{272}$. Havia inicialmente uma participação semanal na Hora do Brasil, ampliada com o surgimento da nova emissora do Ministério, a Rádio Mauá ${ }^{273}$.

Com a troca de telegramas se encerra o périplo de Eugenio D'Alessandro pelo Conselho Nacional do Trabalho na defesa de seus interesses diante de seu algoz e empregador - conhecido como "polvo canadense" -, a The Rio de Janeiro Light and Power.

\footnotetext{
${ }^{270}$ CNT, Processo n. 7.278/1943, fls. 25-6.

${ }^{271}$ CNT, Processo. n. 7.278/1943, fl. 34.

${ }^{272}$ GOMES, Ângela de Castro. A invenção do trabalhismo. $3^{\mathrm{a}}$ ed. Rio de Janeiro: Editora FGV, 2005, op. cit., pp. 211-26.

273 "O sucesso radiofônico de Marcondes Filho foi grande: seu programa recebia muitas cartas - um forte indicador do interesse que despertou nos ouvintes - e provocava elogios. A partir de 1944, foi organizada a Rádio Mauá, a emissora do Ministério do Trabalho. A revista Vamos Ler saúda a inauguração da nova emissora: 'A Rádio Ipanema já não existe! A cidade ouvirá agora outra voz, a voz jovem e sonora da Rádio Mauá, a emissora do trabalhador!' (...) Com a nova emissora, o Ministério do Trabalho passou a implementar um projeto de construção de uma identidade da classe trabalhadora. Manter altos os índices de audiência de uma emissora de rádio não é das tarefas mais fáceis. Respaldado no sucesso alcançado pelo programa Falando aos Trabalhadores Brasileiros, o ministro acreditava que conseguiria colocar a Rádio Mauá entre as emissoras mais ouvidas do Distrito Federal. O principal objetivo da nova emissora era traduzir em linguagem simples a legislação trabalhista, orientando a conduta do trabalhador. Era uma rádio com a programação cuidadosamente voltada para a classe trabalhadora. (...) A grande audiência da emissora concentrava-se no período matutino, em especial nos primeiros horários da manhã, quando os trabalhadores se preparavam para sair para o trabalho. Durante toda a parte da tarde, a Rádio Mauá se mantinha fora do ar, retomando as emissões após as $17 \mathrm{~h}$, sendo que os noticiários para os trabalhadores ocupavam os horários entre $21 \mathrm{~h} 30 \mathrm{e}$ 22h30." CALABRE, Lia. Políticas públicas culturais de 1924 a 1945: o rádio em destaque. Revista Estudos Históricos - Mídia, Rio de Janeiro, n. 31, 2003/1. Disponível em: http:// bibliotecadigital. fgv.br/ ojs/ index.php/ reh/article/viewArticle/2190. Acesso em: 30 out 2012.
} 
A partir daí não se tem mais notícia do destino de D'Alessandro. A Light, que não lograra seu intento se valendo da novel burocracia laboral, conseguiu se livrar de D’Alessandro recorrendo à polícia política getulista.

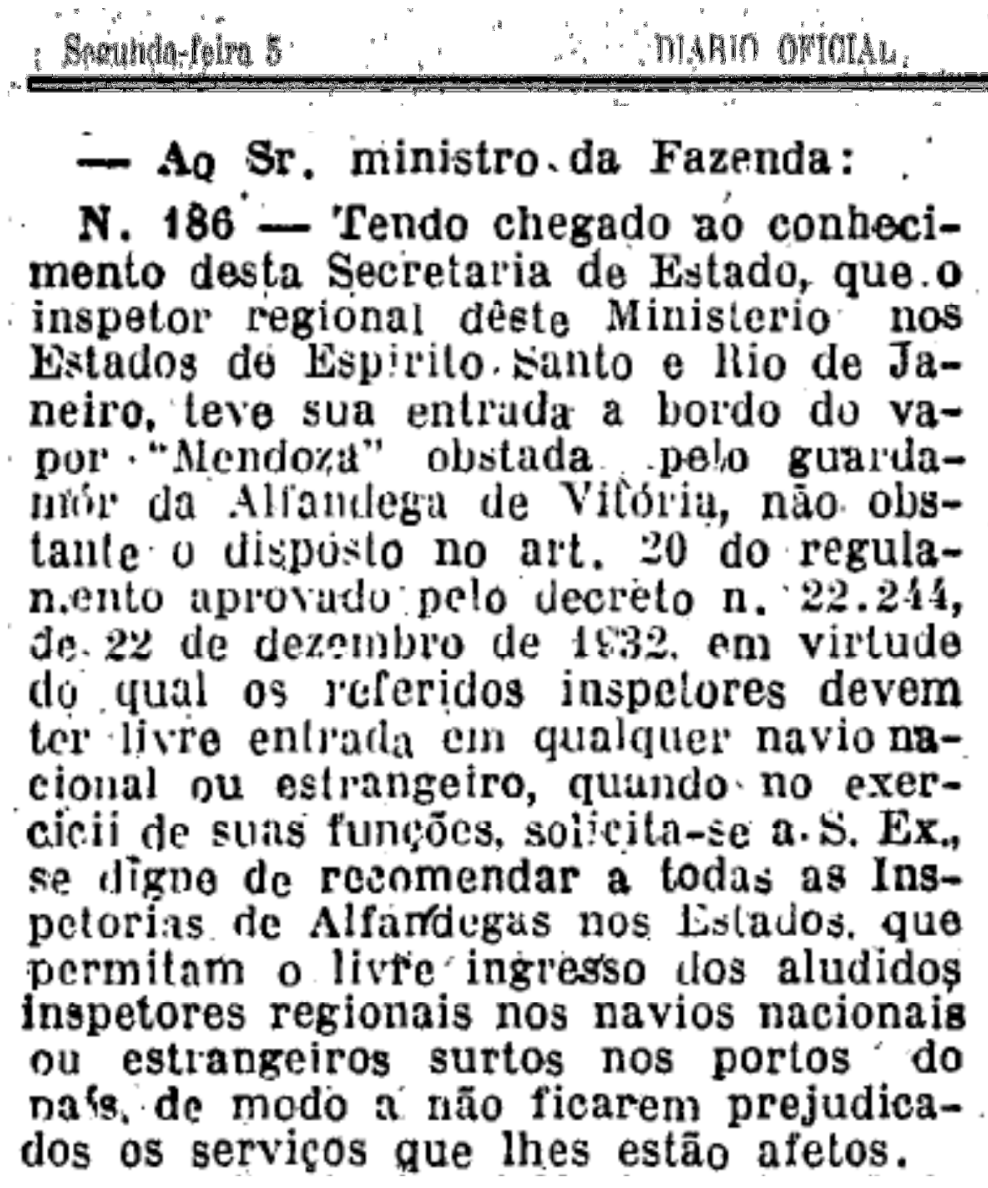

Fotografia 4 - Aviso publicado no Diário Oficial da União de 5 de junho de 1933. O Ministro do Trabalho, Indústria e Comércio, Joaquim Pedro Salgado Filho, pede ao Ministro da Fazenda, Osvaldo Aranha, que permita a inspeção do trabalho em navios no Porto de Vitória, que vinha sendo obstada por servidores da alfândega local. Nele se lê:

"Ao Sr. Ministro da Fazenda

N. 186 - Tendo chegado ao conhecimento desta Secretaria de Estado, que o inspetor regional dêste Ministério nos Estados de Espírito Santo e Rio de Janeiro, teve sua entrada a bordo do vapor 'Mendoza' obstada pelo guarda-mór da Alfandega de Vitória, não obstante o disposto no art. 20 do regulamento aprovado pelo decreto $n .22 .244$, de 22 de dezembro de 1932, em virtude do qual os referidos inspetores devem ter livre entrada em qualquer navio nacional ou estrangeiro, quando no exercício de suas funções, solicita-se a $S$. Ex., se digne de recomendar a todas as Inspetorias de Alfandegas nos Estados, que permitam o livre ingresso dos aludidos inspetores regionais nos navios nacionais ou estrangeiros surtos nos portos do país, de modo a não ficarem prejudicados os serviços que lhe são afetos.

O conflito entre os Ministérios extrapolou os gabinetes e chegou aos processos e diários oficiais. 


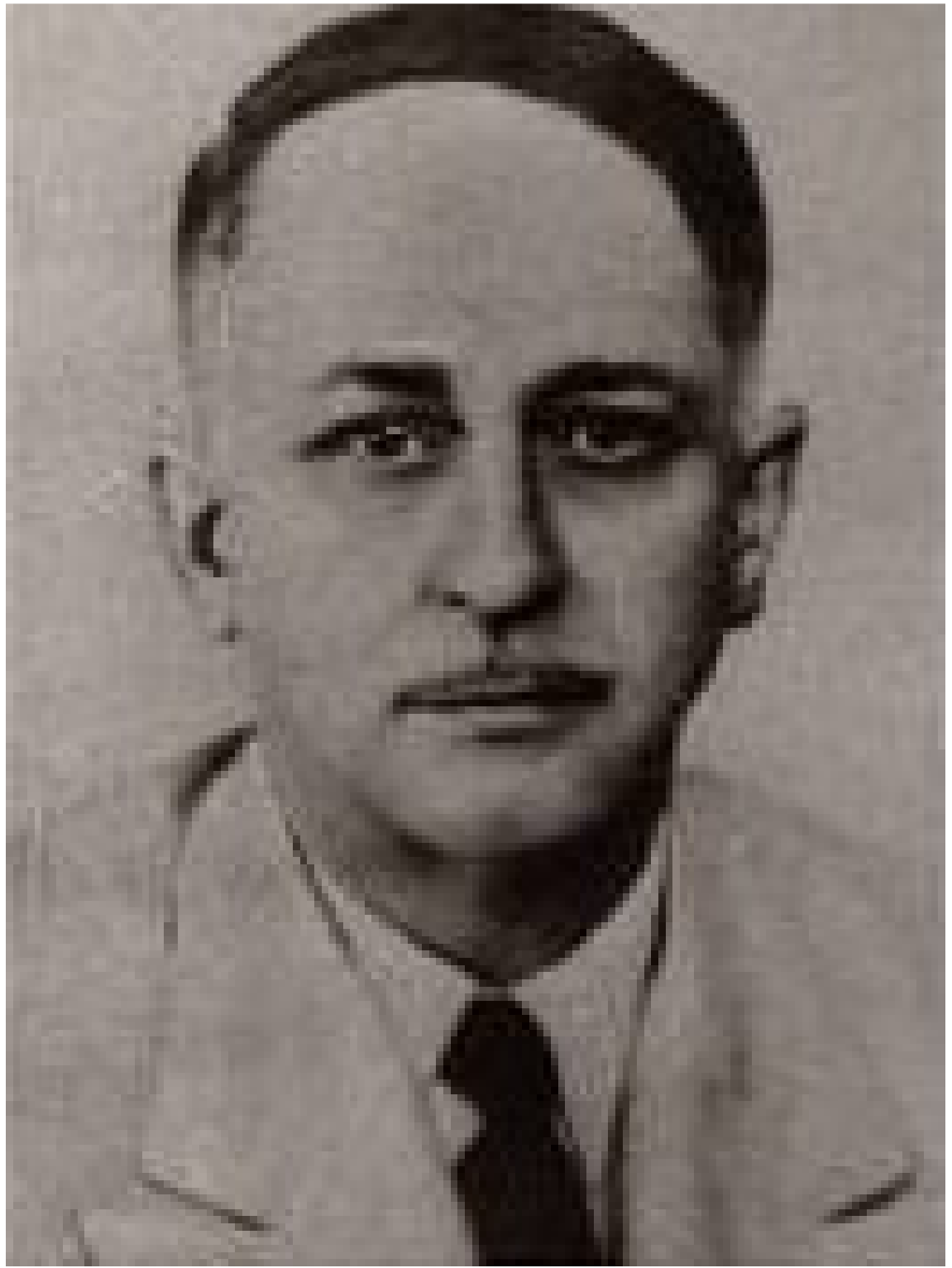

Fotografia 5 - Ministro Alexandre Marcondes Filho

Fonte: $\quad<$ http://portal.mte.gov.br/mte-80-anos/multimidia/fotos/galeria-de-ministros-dotrabalho-de-1930-a-2010.htm> 


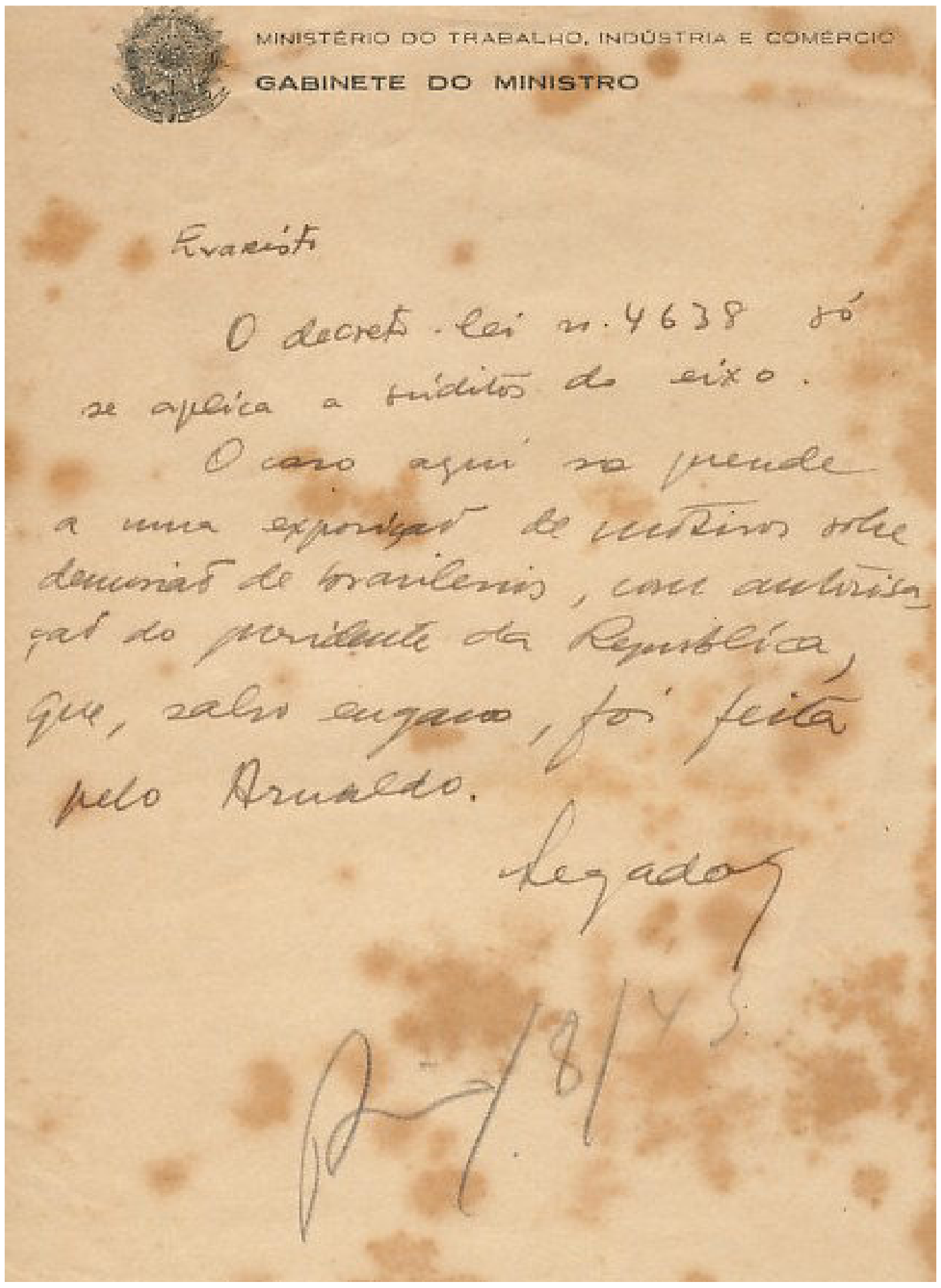

Fotografia 6 - Bilhete escrito por Segadas Viana a Evaristo de Moraes. Nele se lê: "Evaristo O decreto-lei $n .4638$ só se aplica a súditos do eixo.

O caso aqui se prende a uma exposição de motivos sobre demissão de brasileiros, com autorização do presidente da República que, salvo engano, foi feita pelo Arnaldo.

Segadas

Rio/8/45"

Fonte: < http://www.bvemf.ifcs.ufrj.br/imagens/Correspond\%C3\%AAncias/Segadas\% 20Viana\%201943.jpg> 


\section{CONCLUSÃO}

1. "A legislação trabalhista foi toda graciosamente dada ao povo por Vargas. Antes nada havia."

2. "O aparato burocrático criado para tutelar os direitos sociais criados era incipiente e pouco sensível às demandas dos trabalhadores; antes da Consolidação das Leis do Trabalho pouco ou nada foi feito para garantir a efetividade de direitos trabalhistas."

3. “A justiça do trabalho é um ente 'menor', tecnicamente deficiente, que decide de forma parcial, por vezes até mesmo contra legem, sempre favorável ao trabalhador."

4. "A justiça do trabalho é um ente elitista, capturado pelos interesses dos empregadores e, por isso, insensível às demandas dos trabalhadores.”

5. “Antes da inserção da Justiça do Trabalho no âmbito do Poder Judiciário havia órgãos administrativos que decidiam causas trabalhistas, cujas decisões jamais foram cumpridas. A justiça comum, responsável pela execução das decisões administrativas, permitia o reinício da discussão de mérito ou declarava a sua nulidade.”

Essas frases são exemplos de um conjunto mais amplo de máximas do senso comum repetidas hoje sobre a proteção aos direitos sociais - especialmente, trabalhistas e previdenciários -, no Brasil. Tais avaliações sobre o que seja a tutela de direitos sociais ao Brasil nasceram tão logo o sistema de sua proteção foi posto em funcionamento.

A presente dissertação não se destina especificamente a contrariá-las, mas permite chegar a uma conclusão que coloca em dúvida estas e outras afirmações semelhantes: o aparato de distribuição de justiça em matéria de relações de trabalho constituído a partir dos anos 1930 no Brasil não é dado a generalizações. Muitos dos trabalhos historiográficos citados ao longo do texto permitem a mesma conclusão e é nesse conjunto que o presente trabalho buscou se inserir.

De fato, a sistema composto pelo CNT estava longe de ser totalmente ineficaz, como se verificou da análise dos processos das câmaras e do pleno, mas tinha sim problemas de lentidão no trâmite e de efetividade. O cumprimento de suas decisões, embora paulatinamente reforçado ao longo dos anos 1930, ainda sofria ataques nas esferas da justiça comum, que também não deslegitimava as ordens do CNT.

E, de fato, não seria uma tarefa fácil simplesmente ignorar ou desconsiderar as decisões de uma repartição que vinha acumulando desde os anos 1920 uma força 
institucional como órgão de tutela de direitos trabalhistas e previdenciários. O simples represamento das demandas, verificado desde o início do século XX e não afastado pelo CNT de seu âmbito de tutela, dá a dimensão dessa força. As ordens de reintegração vinham muitas vezes após anos de tramitação dos processos. Houve casos de cumprimento espontâneo, noticiados nos autos pelas empresas e pelos trabalhadores. Estes enviavam telegramas de agradecimento aos Ministros do Trabalho, Indústria e Comércio, por vezes acompanhado de exaltações às figuras míticas de Vargas e de sua "criatura" - a legislação trabalhista. $\mathrm{O}$ tempo do processo no CNT constituiu um grande paradoxo. Se a lentidão na resolução dos casos era uma constante, a perseverança daqueles que no passado não viam válvulas de escape para suas demandas é notável. A demora não era obstáculo para quem não tinha a quem reclamar. Os processos movidos por Luiz Carlos de Carvalho contra o Lloyd Brasileiro (Processo n. 48/1934) e por José Diogo Junior contra a Estrada de Ferro Goyaz (Processo n. 975/1934) são exemplos da acumulação dos conflitos. Luiz Carlos foi desembarcado e suspenso em 1915, após o naufrágio do navio que comandava. Nada mais foi dito pelo Lloyd. Contando com mais de dezenove anos de "suspensão" e com quase setenta de idade Luiz Carlos dirige um pleito simbólico ao CNT. Não se tratava de pedir sua reintegração ou vencimentos atrasados, mas tão somente de saber se ainda continuava empregado do Lloyd. Em menor extensão o mesmo ocorreu com José Diogo Junior. Dispensado em agosto de 1931, apresentou reclamação em 1934.

Mas se havia a aceitação da exposição de conflitos represados há muitos anos, o próprio CNT não primava pela solução rápida dos casos. A falta de estrutura, objeto de até mesmo de relatórios ministeriais de atividades dirigidos ao Presidente da República desde 1926 (apenas três anos após a criação do órgão) ${ }^{274}$, a prolixidade do trâmite processual, representado pelo número elevado de laudas de “informações", "encaminhamentos" e despachos de mero expediente em comparação com o número de atos propriamente decisórios do mérito, e a admissão de recursos sem o atendimento dos requisitos legais (principalmente a avocatória), causavam a demora na solução dos conflitos.

A construção dos direitos sociais no Brasil, dadas as características do sistema de proteção colocado à disposição dos trabalhadores, levou à criação por parte dos trabalhadores de um discurso específico, contido pela necessidade de veicular as violações

${ }^{274}$ UNIVERSIDADE DE CHICAGO. Relatório do Ministro da Agricultura, Indústria e Comércio. 1926. Arquivos Brasileiros. Disponível em: < http://brazil.crl.edu/bsd/bsd/u2022/000371.html >. Acesso em: 28 dez 2012. 
em termos jurídicos, próprios dos processos judiciais, com todas as suas virtudes e vícios. Como virtude pode-se mencionar a obrigação de absorver um conhecimento sobre leis e procedimentos, embora haja participação de advogados em alguns processos. Evidentemente esse não era um conhecimento simples e descolado de outros antecedentes formativos e educacionais, mas propiciava a construção de uma consciência sobre os direitos em jogo. Percebe-se, assim, que as postulações perante o CNT eram feitas em sua maioria por integrantes de camadas médias, que trabalhavam em atividades com algum nível de exigência de qualificação. Mas há, por exemplo, a postulação por parte de mineiros da Morro Velho de São João Del Rey, por intermédio do recém-criado sindicato da categoria (Processo n. 9.588/1936). O outro lado da moeda fica por conta da apropriação por parte dos trabalhadores da prolixidade e do estilo quase barroco da linguagem jurídica.

E é razoável supor a existência de uma dimensão coletiva subjacente aos dissídios individuais, como já observou Samuel Fernando de Souza ao analisar os processos dos anos $1920^{275}$. O auxílio do sindicato, as notícias sobre vitórias e derrotas de colegas perante o CNT e a própria propaganda varguista sobre a legislação do trabalho propiciavam alguma coletivização das demandas sobre relações de trabalho. Outra consequência advinda da procedimentalização e do fracionamento das demandas é o isolamento, em certa medida, do conflito de suas repercussões sobre as disputas políticas da época, o que simplificava sua solução e preservava o governo de Vargas de contestações.

\footnotetext{
275 “Acredito que a dimensão formal da reclamação individual em nenhuma hipótese nega o caráter coletivo da relação dos trabalhadores com patrões e instituições de Estado. Há uma aparente confusão quanto se aplica realce ao "dissídio individual", o que nos leva à idéia de uma única pessoa lesada que leva sua reclamação à instituição jurídica e ali, por meio do Estado, resolve a questão. É importante salientar que, embora a instituição jurídica de dissídio individual esteja justificada em contraste com o dissídio coletivo, cabe considerar que no tocante à "sociabilidade", os termos não se aplicam com o mesmo significado com que estão expostos nos textos jurídicos. Percebi este descompasso entre a norma e o funcionamento da estrutura jurídica quando realizava minha dissertação de mestrado. Ali analisei os dissídios individuais dos trabalhadores na indústria calçadista nos anos 1970 e percebi que toda ação judicial tem um caráter "coletivo", desde a construção de sua intenção até a conclusão do processo. A dimensão individual é um conceito de ordem jurídica que deve ser observado com cautela pelo historiador. Afora a relação de trabalhadores no local de trabalho, com trocas de experiências sobre jornadas judiciais nos tribunais de trabalho, vale notar que os dissídios individuais não implicavam a participação de um único reclamante. (...) A 'experiência coletiva' em torno da legislação implica em relações moldadas nos espaços de trabalho e sociabilidade dos trabalhadores. Não é, portanto, determinada pela nomenclatura 'legal', em cumprimento de uma suposta vontade do legislador." em SOUZA, Samuel Fernando de. Coagidos ou subornados: trabalhadores, sindicatos, Estado e leis do trabalho nos anos 1930. 2007. 228 f. Dissertação de Doutorado Instituto de Filosofia e Ciências Humanas, Universidade de Campinas, 2007, pp. 57-8. Disponível em: < http:// cutter. unicamp.br /document/ ?code $=$ vtls000436523>. Acesso em: 16 novembro 2011.
} 
Nessa mesma linha, percebe-se que a repetição do mito da outorga pelos trabalhadores, por meio da exaltação do Estado como grande solucionador de conflitos personificado em última instância em Vargas -, retirava-o da arena de disputas, desresponsabilizava-o pelas violações noticiadas, como se a "outorga" da legislação e de um meio relativamente coativo para a tutela de seu desrespeito fosse papel suficiente para o Estado.

Essa repetição do mito da outorga, geralmente na peça de início do processo e no final do processo - para agradecer a vitória ou para protestar e rogar por intercessão na derrota -, embaçavam ou continham o direcionamento das lutas ao seio do Estado por mais proteção, pela efetividade dos direitos ou pelo ajuste da conduta dos empregadores. $\mathrm{O}$ cidadão trabalhador, nesse contexto, parece ter ficado reduzido a um súdito conformado de Vargas, a quem não cabia confrontar. Se a derrota nas Juntas, Conselhos Regionais e CNT sobrevinha, certamente a responsabilidade não podia ser atribuída a Vargas que, tão logo soubesse da injustiça, mandaria repará-la. Esse é o tom de muitas das cartas dirigidas a Vargas juntadas aos processos analisados. Curiosamente, no entanto, dentro do universo analisado, percebe-se que Vargas não levava sua posição de líder carismático para além do proveito eleitoral e da propaganda visando a sua popularidade, isto é, não há evidências de que mandava rever decisões ou de interferências na atividade do Ministério do Trabalho, Indústria e Comércio. As missivas eram apenas encaminhadas ao CNT "para análise". Parecia haver respeito institucional e até mesmo os conflitos entre ministros foram solucionados dentro da "legalidade", com acatamento de pareceres do Procurador ou do Consultor Geral. O próprio conflito entre o "Ministério da Revolução" e o Ministério de Viação e Obras Públicas sobre a competência do CNT para julgar casos de funcionários públicos, que vinha se desenvolvendo desde a segunda metade dos anos 1920, foi objetivamente resolvido em 1942 com a edição de um decreto-lei, e não com interferências nesse ou naquele processo pontualmente. As avocatórias seguiam a mesma linha de sobriedade. Os Ministros do Trabalho, ao decidirem avocatórias, acatavam pareceres técnicos. Em vários casos o ministro sequer expunha um arrazoado decisório, limitando-se a um "defiro" ou "indefiro" após o parecer do Procurador Geral.

O corpo burocrático de apoio ao Conselho, à sua vez, de despacho em despacho, de encaminhamento em encaminhamento, mostrava o seu comprometimento com a efetivação do "novo direito", embora colaborasse para uma tramitação truncada dos processos. O que em qualquer processo seria desprezível - dezenas de "à vossa consideração", "para análise" e "para providências" -, nos processos do CNT revelam que 
toda a burocracia se sentia autorizada a emitir opiniões e juízos sobre as questões que sobressaíam dos autos. Em cada um dos processos há dezenas de "informações" redigidas pelos burocratas (chefes de sessão e funcionários de secretarias) em que, além de conter um resumo do que havia nos autos até então, formulavam propostas de providências a serem tomadas nos autos e propostas de solução para o caso, salvo melhor juízo. Esse envolvimento do corpo burocrático fica evidente no caso Eugenio D’Alessandro (Processo n. 1.370/1934). Diante da reclamação, adiantou-se às providências da CAP da Light e requisitou o envio do inquérito. O Auxiliar de $2^{\mathrm{a}}$ Classe Luiz Carlos Peres chega a opinar pela improcedência da reclamação, "salvo melhor juízo da Douta Procuradoria" (fl. 95). Parecia haver uma intenção coletiva de fazer novo o "novo direito", na qual todos se sentiam seus intérpretes autênticos.

E, afinal, quem era mais bem sucedido no CNT: patrões ou empregados? Embora não faça parte do escopo da presente dissertação a análise quantitativa dos julgados, pode-se mais uma vez afirmar que há decisões de todo o tipo beneficiando ambas as partes nos conflitos. O tempo do processo e as dificuldades na execução dos julgados pareciam ser os maiores obstáculos ao sucesso dos trabalhadores.

Por outro lado, demonstrou-se que o CNT gozava de relativa autonomia, mesmo em relação à própria máquina do Estado, que lutava para ser excepcionada dos "agravos" trazidos pelo "novo direito", ora se apoiando na cláusula constitucional de insindicabilidade dos atos do governo provisório, ora recorrendo a uma argumentação consequencialista, ora simplesmente desqualificando a instituição emissora da decisão desfavorável. Nos casos do comandante Luiz Carlos de Carvalho (Processo n. 48/1934, contra o Lloyd Brasileiro) e do ajudante de almoxarife José Diogo Junior (Processo n. 975/1934, contra a Estrada de Ferro de Goyaz) o conflito entre ministros do governo de Vargas ficou explícito nos autos.

Essa relativa autonomia também não foi graciosamente dada por Vargas ou garantida solenemente neste ou naquele decreto. A cada nova reclamação o CNT era colocado diante de distintas situações que colocavam sob ameaça o solitário direito de estabilidade decenal dos trabalhadores que o demandavam. Ao longo dos anos é perceptível o esforço do CNT em ampliar a afirmação de direitos acessórios - direitossatélites em princípio retirados da competência do Conselho - como forma de tutelar a estabilidade decenal. Esta passa a ser vista como um núcleo atacável por meio de diversas práticas indiretas dos empregadores visando à sua cessação ou impedindo a sua aquisição. A esse respeito é emblemático o processo movido por Antonio Soares, empregado da Saint 
John d'El Rey Mining Co. Ltd. (Processo n. 9.588/1936), em que o CNT aprofunda a investigação dos motivos da redução salarial provada pelo empregado, mas mal explicada pela empresa. Casos anteriores, em que o CNT se via imobilizado por sua restrita competência, fizeram com que o CNT construísse uma interpretação pela qual a tolerância com reduções salariais deveria ser estreita. Sem justificativas robustas jamais deveriam ser aceitas, pois as reduções salariais repentinas, sem motivo, constituíam expediente corrente e bastante eficaz para abalar a estabilidade decenal já adquirida ou para impedir o seu implemento às vésperas de estarem completos os dez anos de serviço. A elas se combinavam inquéritos com características inquisitoriais, rebaixamentos de cargos e posições, além de suspensões por prazo indeterminado. Esse entendimento viria a beneficiar, por exemplo, Ambrosio Scarpim, na reclamação movida em face da Rede de Viação Paraná - Santa Catharina (Processo n. 144-1937).

Todavia, diante da importância do direito-núcleo tutelado (estabilidade decenal), tolerar suspensões fazia parte de uma política de contenção de danos maiores. Afinal, a estabilidade significava o fim do poder diretivo do empregador? A resposta certamente é não, mas importava não sinalizar com rigores excessivos bem como ceder em balizas razoáveis, objetivas e, por isso, seguras. O processo de construção de uma tutela efetiva dos direitos sociais deveria estar sempre sob controle, de modo a evitar sobressaltos que colocassem o sistema todo em xeque, com consequências potencialmente devastadoras no campo político para Vargas. A liberdade dada aos empregadores para punir empregados com suspensões de até 90 (noventa) dias significava, ao mesmo tempo, uma autocontenção do CNT quanto ao seu campo competencial e uma clarividência sobre o foco de sua atuação (estabilidade decenal). O esforço hermenêutico é notável; estendeu-se uma regra de regulamento aplicável à categoria dos bancários para todos os trabalhadores. Iam-se os anéis, mas ficavam os dedos. E também começavam a se abrir portas para as críticas quanto à "técnica", à "legalidade" e à "correção" de tais interpretações.

Esse movimento de ampliação colateral da afirmação de direitos acessórios é visível no avanço da análise da ordem cronológica crescente dos processos. Se ainda no início dos anos 1930 à documentação emitida unilateralmente pelo empregador o CNT atribuía um peso quase absoluto, já na segunda metade da década o quadro se altera. Regras de distribuição do ônus da prova passam a ser aplicadas para relativizar o conteúdo de documentos e alegações trazidas pelos empregadores. No processo movido por Alexandre Rodrigues contra a Estrada de Ferro Araraquara (Processo n. 446/1937), o rigor do olhar do CNT para o inquérito se traduziu em atribuir o ônus probatório à empresa 
quanto à ocorrência da falta grave. Parece trivial, mas certamente não para o padrão que o CNT vinha imprimindo em seus julgamentos até os primeiros anos da década de 1930. No caso de Rodrigues a alegada conduta de apagar com borracha os talões para permitir seu reaproveitamento posterior não foi levada em conta nem mesmo com a juntada dos próprios talões aos autos. Para o CNT o exame pericial era fundamental, mormente em função da qualidade inferior do papel. Ou seja, teriam sido os bilhetes realmente manipulados pelo empregado diante de um papel frágil e cheio de imperfeições provenientes de seu próprio fabrico? Esse tipo de questão, própria dos juízos de valoração probatória, passou a ser formulada com maior frequência nos processos.

$\mathrm{O}$ mesmo caso é exemplo de como o CNT passou a conferir pesos relativos às ocorrências registradas na "fé de ofício" do empregado trazida aos autos. Essas folhas contendo o histórico funcional do empregado, preenchidas e arquivadas unilateralmente pelas empresas, muitas vezes traziam anotações desabonadoras em meio a outros registros de praxe. No caso de Rodrigues, a honrosa anotação de louvor pelo probo ato de entregar a carteira perdida por um passageiro pesou bastante no juízo de probidade feito pelo CNT. Já seus problemas com o consumo de álcool foram praticamente desprezados; nada tinham a ver com os fatos relatados nos autos. A valoração mais detida e aguda da prova, combinada com as instruções para o processamento de inquéritos emitidas a partir de 1933, passaram a sinalizar uma afirmação institucional do próprio CNT enquanto órgão de tutela de direitos sociais.

No mesmo sentido, também começa a entrar no horizonte de soluções protetivas da estabilidade a proporcionalidade na aplicação da sanção. Os fiscais da The Manáos Tramways and Light Company Limited, Adelino Medeiros Barbosa, João Manoel das Neves e Pedro Veríssimo da Silva (Processo n. 564/1939), foram absolvidos pela Segunda Câmara do CNT, que desconsiderou a vaga prova testemunhal colhida no inquérito e, principalmente, observou que nem sequer lhes havia sido aplicada pena de suspensão anterior. Na verdade, implicitamente, ao delinear o campo da falta grave, o CNT abria caminho para a exigência de gradação das penalidades. Com isso a dispensa do estável ficaria isolada nos estreitos limites das medidas de ultima ratio. Observa-se que o que parecia uma proteção restrita e frágil aos direitos sociais - a garantia de estabilidade decenal como direito-núcleo isolado, delimitador da escassa competência do $\mathrm{CNT}^{276}$ - vai ganhando força pela ação imunizadora dos entendimentos jurisprudenciais que iam se

\footnotetext{
${ }^{276}$ Ao menos até que passassem a ser admitidos recursos da Juntas e Conselhos Regionais para o CNT.
} 
consolidando. À falta de outros direitos sob sua tutela, o CNT reforçava aquele que lhe era dado proteger.

O contraponto daquilo que ora se conclui pode ser exemplificado pela reclamação em que foram partes José Diogo Junior e a Estrada de Ferro Goyaz (Processo n. 975/1934). Entre a "certidão de contagem" de tempo de serviço emitida por contador da própria Estrada e as simples alegações desta acerca da invalidade do conteúdo certificado (dada a perda dos arquivos da Estrada anteriores a 1920), o CNT preferiu estas últimas, sem que tenham sido trazidas as respectivas evidências de suporte aos autos.

E se a afirmação de um conjunto de prerrogativas e direitos tendentes a servir de escudo à estabilidade decenal era um caminho necessário a ser trilhado pelo CNT, também era igualmente necessário desarmar e afastar interpretações destinadas a enfraquecê-la. No Processo n. 12908/37, em que contendiam José Ignacio e a Estrada de Ferro Leopoldina, a solução para o caso - favorável ao trabalhador - apareceu apenas em sede de avocatória ministerial, apoiada em parecer do Procurador Geral. O acórdão afastou a tese da Leopoldina - até então bem sucedida nos autos - segundo a qual o ônus da prova da contagem do tempo de serviço deveria recair sobre o empregado. E mais: não bastava a simples prova do termo inicial e do termo final da prestação de serviços, mas sim de que em todo o interregno houve prestação efetiva de serviços por parte do trabalhador. Verdadeira probatio diabolica, não tanto pela dificuldade de provar o fato, mas pela definição mesma do que se entendia por "efetividade". Quais pausas ou interrupções seriam tomadas como relevantes para a suspensão da contagem? Prevalece então a interpretação dada pelo Ministro ao artigo 53, do Decreto n. 20.465/1931, para afirmar a inexistência do que em sua literalidade de fato não se continha, isto é, a exigência de prestação de serviço "efetivos", "constantes" ou "ininterruptos" ao mesmo empregador por ao menos dez anos. Daí a proteção da estabilidade decenal abre caminho para colocar ao abrigo da juridicidade o tempo à disposição do empregador - o que quer que esteja o empregado fazendo no período - afastando a imposição da produção de prova da prestação de serviços amiúde. Como consequência, passa-se a opor ao empregador de forma mais aguda as anotações e registros que levou a efeito nas fés de ofício e nas carteiras profissionais. Assim, presumiam-se relativamente verdadeiras tais anotações e registros, admitindo-se prova em contrário. Sinalizou-se às empresas que o documento por ela unilateralmente produzido e guardado não seria tomado em conta apenas para afastar alegações do trabalhador, mas também poderia ser utilizado como prova contra os interesses do próprio empregador. 
São poucos os processos em que há votos divergentes; a maioria das decisões foi tomada por unanimidade. Digno de nota é o voto emitido pelo Conselheiro Paranhos Fontenelle no processo em que eram partes Eugenio D'Alessandro e The Rio de Janeiro Tramway Light and Power. O voto vencido expõe claramente a disputa existente à época no campo das ideias políticas e jurídicas. O "novo direito" era considerado inadequadamente agudo e invasivo por muitos juristas formados segundo uma tradição liberal. $\mathrm{O}$ voto agressivo de Fontenelle evidencia o embate entre concepções mais próximas de um direito privado, de matriz liberal, e concepções que buscam uma identidade hermenêutica para o "novo direito", com recurso a mens legis, equidade, vontade do legislador e outros topoi argumentativos, ainda que raramente seu conceito ou conteúdo propriamente jurídico aparecessem claramente explicitados nos processos. Mas mesmo o voto divergente - com forte apelo à interpretação gramatical do artigo 53 - ao final invoca a "tradição" do "novo direito" e o mantra da equidade, que não valia como lugar comum argumentativo para todos os estudiosos dos desdobramentos jurídicos da questão social.

A partir dos processos é possível identificar uma permanência do conjunto argumentativo próprio do direito civil para justificar soluções no campo do "novo direito". Não são frequentes as citações dos doutrinadores do "novo direito", embora à época já houvesse uma plêiade de manuais e obras de referência nas áreas trabalhista e previdenciária. É emblemático o parecer do Consultor Geral da República, Orozimbo Nonato, no processo n. 12.908/1937 (Benjamin Aprigio Pavão versus Lloyd Brasileiro), em que, embora a opinião sobre a necessidade de regulamentação da estabilidade decenal dos marítimos viesse naturalmente apoiada em comentadores do Código Civil de 1916 e de publicistas em voga na época, ao final acabou lançando mão de um recurso argumentativo fulcral para o "novo direito" - a equidade. Deve-se considerar, no particular, que Orozimbo Nonato tinha formação predominantemente privatística.

De fato, a equidade se constitui como uma ideia-força do "novo direito" - para uns a sua maior virtude, para outros seu pecado original -, legitimadora de toda e qualquer interpretação e aplicação da legislação trabalhista, mesmo quando parecia um recurso expletivo, como no caso do parecer de Orozimbo Nonato.

A escassez de referências conceituais nos processos era suprida pela doutrina do "novo direito". A Revista do Trabalho trazia frequentemente artigos sobre o papel da equidade no "novo direito", tendo por base as análises de civilistas sobre os artigos $4^{\circ}$ e $5^{\circ}$, 
da Lei de Introdução do Código Civil ${ }^{277}$, e referindo sempre com vagas - e quase tautológicas - advertências sobre os limites de sua aplicação. O advogado Antonio Valença de Mello, em artigo sobre o tema publicado na Revista do Trabalho de janeiro de 1944, não fugiu dessa linha:

\begin{abstract}
“A Equidade não significa que o Direito adquire extenção infinita e que em campo dilatado surge em frente ao julgador.

Antes pelo contrário, sem lei ou fonte em que se apoie, o juiz tem de verificar, entre as múltiplas soluções que para o caso puder conceber, a mais justa, a mais conveniente, a que melhor atende, de acôrdo com o disposto no aludido art. $5^{\circ}$, 'aos fins sociais a que a lei se dirige e às exigências do bem comum', posto que atender a uma exigência do bem comum seja a finalidade social e única do Direito.

Assim, na ausência de lei ou diante de uma lei defeituosa, isto é, um preceito que se tornou antiquado ou que não póde ser aplicado por encerrar absurdo ou injustiça, êle deve coligir os elementos para formular a regra jurídica adequada ao caso que tem de decidir ou, nos termos do art. 114 do Código de Processo Civil, 'a norma que estabeleceria se fôsse o legislador'.,"278
\end{abstract}

Não à toa Orlando Gomes, em seu A Crise do Direito, apontaria o direito do trabalho como um "direito-teste" do ordenamento jurídico, destinado a experimentações em sua aplicação e interpretação.

Vale observar ainda que em um grande número de processos não há rigor na análise do cabimento do recurso de embargos e da avocatória. Divergências jurisprudenciais e "documentos novos" não eram exigidos, o que fazia do Pleno do CNT e do próprio Ministro do Trabalho, Indústria e Comércio, respectivamente, um prolongamento das instâncias ordinárias.

O processo de Eugenio D'Alessandro, à sua vez, é repleto de referências simbólicas da época e, por isso, contém em si enorme capacidade explicativa dos fenômenos estudados.

\footnotetext{
${ }^{277}$ Decreto-lei n. 4.657/1942. Art. 4º Quando a lei for omissa, o juiz decidirá o caso de acordo com a analogia, os costumes e os princípios gerais de direito.

Art. $5^{\circ} \mathrm{Na}$ aplicação da lei, o juiz atenderá aos fins sociais a que ela se dirige e às exigências do bem comum. ${ }^{278}$ MELLO, Antonio Valença de. Conceito de equidade nas diretrizes sociais: os arts. $4^{\circ}$ e $5^{\circ}$ da Lei de Introdução do Código Civil. Revista do Trabalho. Rio de Janeiro, ano XII, n. 1, p. 15, jan 1944.
} 
É de se notar o bom uso da língua portuguesa por parte de D’Alessandro em seus arrazoados. Mas o destaque certamente recai sobre o uso quase profissional de argumentos jurídicos e sobre o manejo competente da legislação trabalhista da época. Vários dos documentos por ele juntados aos autos datam ainda dos anos 1920, denotando que, estrategicamente, D'Alessandro os vinha reunindo, como se soubesse quando, como e porque teria que lançá-los em uma disputa. D'Alessandro chega a citar o rumoroso caso Dreyfus, comparando sua situação à do oficial judeu injustamente condenado com base em documentos falsos ${ }^{279}$, ao reclamar da longa duração do inquérito para apuração de falta grave a que foi submetido pela Light ("Essa historia [inquérito] teve fim em 17 de Abril, depois de ter decorridos quase 18 mezes, batendo o 'record' do processo Dreyfus" ${ }^{\text {"280 }}$ ). Para Eugenio D'Alessandro o caso Dreyfus era o paradigma da suprema injustiça.

Também digna de menção é a riqueza de detalhes com que D'Alessandro defende, com argumentos técnicos sobre o funcionamento da usina de reserva, a necessidade imperiosa do posto de assistente ao chefe. O primeiro arrazoado de D'Alessandro nos autos do processo principal - sua defesa contra a aposentadoria contém 24 (vinte e quatro) documentos, dentre eles uma cópia do contrato de concessão firmado pela Light com o município do Rio de Janeiro, para comprovar a obrigatoriedade da construção de uma usina térmica de reserva, pronta a operar diante de qualquer problema com a geração hidrelétrica.

Além de letrado e consciente de seus direitos, D'Alessandro demonstrou ter condições financeiras de levar adiante o processo. Juntou aos autos diversas certidões e "públicas formas", todas estampadas com os selos comprobatórios do recolhimento dos emolumentos e taxas devidos. Mais uma vez verifica-se a predominância das camadas médias no CNT. Há outras semelhanças do caso D'Alessandro com os demais processos analisados: o longo período de tramitação, a resistência da Light em cumprir espontaneamente as decisões do CNT, a consequente necessidade de levá-las à execução perante a justiça comum, as referências laudatórias a Vargas em seus arrazoados.

Mas a ordinariedade de D'Alessandro cessa por aí. Militante antifascista, talvez convertido ao fascismo posteriormente, com "brilhante fé de ofício", implicado na grande

${ }^{279}$ Cf. ARENDT, Hannah. O caso Dreyfus. In: . As origens do totalitarismo. São Paulo: Companhia das Letras, 1989.

${ }^{280}$ Processo n. 1.370/1934, fl. 59. Outra referência aparece no apensado Processo n. 5.321/1935, fls. 29-30 ("Mas a maior gravidade, então como agora, residia no fato em que, sem a revisão desse 'processo Dreyfus' e de outros milhares que se efectuam aqui e acolá, a sociedade ficaria exposta e continuamente ameaçada pela acção satanica de individuos sem escrupulo, em goso de plena liberdade, practicando actos de criminosa audacia"). 
greve de 1932, perseguido pela polícia política varguista, denunciado pela Embaixada da Itália. A preocupação da Light com Eugenio D’Alessandro revelou-se extraordinária, talvez por sua militância junto aos demais empregados, talvez por pressões da Embaixada. A alta direção canadense e inglesa da empresa participou diretamente dos inquéritos e dos processos movidos no CNT. As peças dos autos transparecem uma vontade exacerbada do "polvo canadense" de afastar D'Alessandro, a ponto de ter sido destacado para cuidar do caso um importante causídico e professor de direito da época, Alcebíades Delamare. Membro do laicato católico brasileiro, que vinha reverberando as preocupações da doutrina católica com a questão social, Delamare abandonou o discurso no exercício da função de advogado. As ações de Delamare no processo chegaram a ser censuradas pela burocracia de apoio - como se houvesse um abuso do direito ao contraditório -, quando insistiu em pedido de vistas com o intuito de ofertar "razões de contradicta" à contestação de D’Alessandro a um arrazoado da Light. As "informações" da burocracia detectam excesso no contraditório, mas terminam justificando o indeferimento por não ser essa a "praxe administrativa" do CNT.

$\mathrm{O}$ acórdão dos embargos interpostos pela Light confere uma interpretação à possibilidade de aposentadoria em detrimento da estabilidade decenal, na superveniência de "novas invenções" ou na supressão de serviço da empresa, determinando que se trata de hipótese de todo excepcional. Uma mescla de análise gramatical, consequencialismo (Caixas e Institutos “quebrariam”) e enunciação de palavras para além do texto legal, sob os fundamentos do espírito da lei e da vontade do legislador. O CNT passa a exigir a prova da impossibilidade de aproveitamento dos empregados em outras funções com atividades e remuneração semelhantes, requisito não expresso no decreto. Por outro lado, o acórdão afasta os pareceres técnicos produzidos pelos engenheiros da Light, afirmando sua evidente parcialidade.

O longo e tortuoso percurso de D'Alessandro pelo CNT combinado com a perseguição por parte da polícia política do regime varguista revela que, em alguma medida, a questão social continuou a ser questão de polícia ${ }^{281}$ no período, sendo tratada "à pata de cavalo", conforme expressão repetida pelo próprio D’Alessandro em seus arrazoados.

\footnotetext{
${ }^{281}$ John French discute o uso que a política varguista fez do aforismo "a questão social é um caso de polícia" como figura de linguagem fundamental do discurso do mito fundador de toda a proteção social após a Revolução de 1930, e afirma que não há comprovação histórica de que Washington Luís tenha pronunciado a frase. FRENCH, John. Proclamado leis, metendo o pau e lutando por direitos: a questão social como caso de polícia, 1920-1964. In: LARA, Silvia Hunold; MENDONÇA, Joseli Maria Nunes. Direitos e justiças no Brasil. Campinas, Editora UNICAMP, 2006, pp. 379-416.
} 
E embora D'Alessandro tenha detectado uma certa continuidade do tratamento tradicionalmente dispensado à questão social no Brasil não deixou de repetir o mito da outorga. Em suas petições e arrazoados D’Alessandro demoniza a Caixa da Light, seus chefes, a própria Light bem como a Junta de Conciliação e Julgamento, que não teria acolhido seu pleito quanto à suspensão que resultou do inquérito, mas coloca o Ministro do Trabalho e Getúlio como grandes benfeitores, com poderes especiais para prover-lhe o que pedia. 


\section{REFERÊNCIAS}

ACADEMIA BRASILEIRA DE LETRAS. Levi Carneiro. Verbete biográfico disponível em: <http://www.academia.org.br/abl/cgi/cgilua.exe/sys/start.htm?sid=271 >. Acesso em: 06 set 2012 .

ALMEIDA JUNIOR, João Mendes. Direito Judiciário Brasileiro. Rio de Janeiro: Freitas Bastos, 1940.

ANTUNES, Ricardo. Classe operária, sindicatos e partido no Brasil: da revolução de 30 até a Aliança Nacional Libertadora. $2^{\mathrm{a}}$ ed. São Paulo: Cortez/Ensaio, 1982.

ARAÚJO, Rosa Maria de. O batismo do trabalho: a experiência de Lindolfo Collor. Rio de Janeiro: Civilização Brasileira, 1981.

ARENDT, Hannah. O caso Dreyfus. In: . As origens do totalitarismo. São Paulo: Companhia das Letras, 1989.

ARRUDA, Hélio Mário de. Oliveira Vianna e a legislação do trabalho no Brasil. São Paulo: LTr, 2007.

BARATA, C.E.A.; BUENO, A.H.C. Dicionário das famílias brasileiras. São Paulo: Originis-X, 1999.

BARBOSA, Ruy. A questão social e política no Brasil. Rio de Janeiro: Casa de Rui Barbosa. Disponível em:

$<\mathrm{http}$ //www.casaruibarbosa.gov.br/dados/DOC/artigos/rui_barbosa/p_a5.pdf $>$, acesso em 10 jun 2011.

BARROS, Alamiro Bica Buys de. Direito industrial e legislação do trabalho. Rio de Janeiro: Coelho Branco, 1940-1942. 2 v.

BARROS, Silva. Manual de licenças: grupamento das disposições legaes, doutrina e jurisprudencia, em vigor, sobre licenças, aposentadoria, dispensas do serviço e accidentes de trabalho. Rio de Janeiro: Alvaro Baptista, 1929.

BATISTA, Francisco de Paula. Compendio de theoria e pratica do processo civil comparado com o commercial e de hermeneutica juridica: para uso das faculdades de direito do Brazil. Paris: Garnier, 1901.

BERCOVICI, Gilberto. Instabilidade constitucional e direitos sociais na Era Vargas. In: BITTAR, Eduardo, C. B. História do direito brasileiro. São Paulo: Atlas, 2003.

BERTONHA, João Fábio. Sob a sombra de Mussolini: os italianos de São Paulo e a luta contra o fascismo, 1919-1945. São Paulo: Annablume, 1999.

BEZERRA, Celso de. O trabalhador e o estado nacional. Revista do Conselho Nacional do Trabalho. Rio de Janeiro, n. 18, pp. 85-90, jan-fev 1944 
BOMFIM, Benedito Calheiros. A consolidação trabalhista vista pelo Supremo Tribunal Federal. Rio de Janeiro: José Konfino, 1959.

. Jurisprudência do contrato de trabalho: os artigos 442 a

510, da CLT, vistos pelos tribunais superiores. Rio de Janeiro: Conquista, 1955.

. Jurisprudência do processo trabalhista: os arts. 763 a

922, da CLT, interpretados pelo Supremo Tribunal Federal e Tribunal Superior do

Trabalho. Rio de Janeiro: Conquista, 1957.

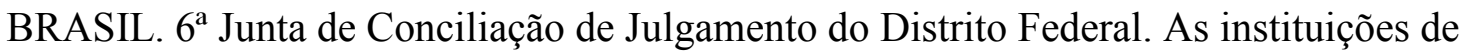
caridade (no caso Hospício Nossa Senhora da Saúde), as puramente culturais, científicas, etc., cujo fim é exclusivamente o bem comum ideal, não estão sujeitas às sanções da Lei 62, de 5 de junho de 1935. Processo n. 518-42. Revista do Trabalho, ano X, n. 17, p. 17 , ago. 1942.

Actos officiaes: leis, decretos e portarias. Rio de Janeiro: Departamento de $\overline{\text { Estatística e Publicidade, 1934. separatas 1, } 2 \text { e } 3 .}$

. AGU. Parecer do Consultor Geral da República Francisco Campos a pedido do Ministério da Fazenda (Aviso n. 240, de 21 de outubro de 1935). Exarado em 07 de janeiro de 1936. Ementa: ASSUNTO: Pagamento de vencimentos atrasados a Pedro Teixeira Mazolleni, $1^{\circ}$ tenente da Polícia Militar do Distrito Federal. Disponível em: http://www.agu.gov.br/sistemas/site/PaginasInternas/NormasInternas/AtoDetalhado. aspx?idAto=2826. Acesso em: 18 out 2011.

Conselho Nacional do Trabalho, Contrato de "marchandage". Caracterização. Prescrição. Alteração do contrato de trabalho. Recurso Extraordinário n. 7.103/44. Francisco Ribeiro versus Companhia Docas de Santos. Relator: João Duarte Filho. Rio de Janeiro, 09 jul 1945. Jurisprudência: Conselho Nacional do Trabalho, Conselhos Regionais do Trabalho e Juntas de Conciliação e Julgamento, Rio de Janeiro: Imprensa Nacional, 1946. v. XXVIII. p. 15-18.

Dez anos de legislação social: ementário dos atos oficiais expedidos de 1930 a 1940. Rio de Janeiro: Imprensa Nacional, 1940.

Discursos pronunciados na Faculdade de Direito de Niterói, no dia 04 de junho de 1946, nas homenagens prestadas ao Dr. Geraldo Bezerra de Menezes, presidente do Conselho Nacional do Trabalho. Rio de Janeiro: Imprensa Nacional, 1946.

. Documentos parlamentares: legislação social. Rio de Janeiro: Typ. do Jornal do Commercio, 1920. v. 2.

Jurisprudência: Conselho Nacional do Trabalho, Conselhos Regionais do Trabalho e Juntas de Conciliação e Julgamento, Rio de Janeiro: Imprensa Nacional, 1946. v. XXVIII. 
. Jurisprudência: Conselho Nacional do Trabalho, Conselhos Regionais do Trabalho e Juntas de Conciliação e Julgamento, Rio de Janeiro: Imprensa Nacional, 19411946. $28 \mathrm{v}$.

. Justiça do trabalho: decretos-leis e decretos, regimento interno do CNT, regimento interno dos CRT, Portaria n. CE-56-41, tabela de custas. Rio de Janeiro: Imprensa Nacional, 1942.

Ministério do Trabalho, Indústria e Comércio. Aumento de salário em caráter definitivo. Parecer n. 5.612-94, Relator: Oscar Saraiva. 08 dez 1941. Revista do Trabalho, ano X, n. 1, p. 25, jan. 1942.

. MTIC. Dez anos de legislação social: ementário dos atos oficiais expedidos de 1930 a 1940. Rio de Janeiro: Imprensa Nacional, 1940. ago. 1942.

Portaria Ministerial n. 839. 17 jul 1942. Revista do Trabalho, ano X, n. 3, p. 16, Portaria n. 790. 22 jan 1942. Revista do Trabalho, ano X, n. 1, p. 26, jan. 1942.

Nacional, 1925-1946. vv.

Revista do Conselho Nacional do Trabalho. Rio de Janeiro: Imprensa

Supremo Tribunal Federal. $1^{\text {a }}$ Turma. Acórdão n. 94.994. 15 abr 1941. Jornal do Comércio. apud BRASIL. Exposição de Motivos. Decreto-lei n. 4.037. 19 jan 1942. Ministro Alexandre Marcondes Filho. Revista do Trabalho, ano X, n. 1, p. 6, jan. 1942.

. Tribunal Superior do Trabalho. CGEDM. Organograma Evolutivo do Conselho Nacional do Trabalho. (documento interno não publicado, disponível sob demanda) . Tribunal Superior do Trabalho. Fundo Conselho Nacional do Trabalho.

Descrição. Disponível em: < www3. tst.jus.br/ Srcar/ Documentos/ CNT_Descricao_ Internet.pdf $>$, acesso em 18 maio 2011.

CALABRE, Lia. Políticas públicas culturais de 1924 a 1945: o rádio em destaque. Revista Estudos Históricos - Mídia, Rio de Janeiro, n. 31, 2003/1. Disponível em: http:// bibliotecadigital. fgv.br/ ojs/ index.php/ reh/article/viewArticle/2190. Acesso em: 30 out 2012.

CALIL, Gilberto. Partido de Representação Popular: estrutura interna e inserção eleitoral (1945-1965). Rev. Bras. Ciênc. Polít., Brasília, n. 5, Julho 2011. Disponível em: $<\mathrm{http}$ // www.scielo.br/scielo.php? script=sci_arttext\&pid $=$ S0103-33522011000100013\& $\operatorname{lng}=\mathrm{en} \& \mathrm{nrm}=$ iso $>$. Acesso em: 18 nov. $20 \overline{1} 1$.

CÂMARA DOS DEPUTADOS. Legislação social: documentos parlamentares - 18931920. v. 2. Rio de Janeiro: Jornal do Commercio, 1920.

CARNEIRO, Maria Luiza; KOSSOY, Boris (org.). A imprensa confiscada pelo DEOPS. São Paulo: Ateliê Editorial/Imprensa Oficial do Estado de São Paulo/Arquivo do Estado, 2003. 
CARPEAUX, Otto Maria. Alceu Amoroso Lima por Otto Maria Carpeaux: Alceu, Houaiss e Callado rememoram Carpeaux. Rio de Janeiro: Edições Graal, 1978.

CARVALHO, José Murilo de. A formação das almas: o imaginário da República no Brasil. São Paulo: Companhia das Letras, 1990.

Civilização Brasileira, 2012

Cidadania do Brasil: o longo caminho. Rio de Janeiro:

. Cidadania, estadania e apatia. In: Jornal do Brasil, 24 jun

2001, p. 8 .

Janeiro, nº18, 1996.

. Cidadania: tipos e percursos. Estudos Históricos, Rio de

Os bestializados: o Rio de Janeiro e a República que não foi. $3^{\text {a }}$ ed. São Paulo: Companhia das Letras, 2010.

Horizonte: Editora UFMG, 2005.

Pontos e Bordados: escritos de história e política. Belo

CARVALHO, Manoel Cavalcanti de. Direito sindical e corporativo. Rio de Janeiro: A. Coelho Branco Filho, 1941.

CASTRO FILHO, José Ribeiro de. O problema da jurisdição no direito do trabalho. Belo Horizonte. Tese apresentada em concurso para a cátedra de direito industrial e legislação do trabalho da Faculdade de Direito de Goiânia, 1938.

CASTRO, Augusto Olympio Viveiros de. A questão social. Rio de Janeiro: Editora Conselheiro Candido de Oliveira, 1920.

. O direito de greve e as suas limitações:

necessidade de um código do trabalho. O Direito, v. 40, n. 118, p. 273-89, maio-ago 1912.

CASTRO, Raimundo de Araujo. Justiça do Trabalho. Rio de janeiro: Freitas Bastos, 1941.

CEPÊDA, Vera Alves. Contexto político e crítica à democracia liberal: a proposta de representação classista na Constituinte de 1934. In: MOTA, Carlos Guilherme; SALINAS, Natasha S. C. (Org.). Os juristas na formação do Estado-nação brasileiro: 1930 - dias atuais. São Paulo: Saraiva, 2010.

CESARINO JUNIOR, Antônio Ferreira. Direito corporativo e direito do trabalho: soluções práticas. São Paulo: Livraria Martins, 1942. 2 v.

1970.

Direito social brasileiro. São Paulo: Saraiva, 
CHALHOUB, Sidney. Trabalho, lar e botequim: o cotidiano dos trabalhadores no Rio de Janeiro da belle epóque. Campinas: Editora da UNICAMP, 2001.

COLLOR, Lindolfo. Discursos e manifestos: 1936-1937. PortoAlegre: Livraria do Globo, 1937.

. Europa 1939. Porto Alegre: Fundação Paulo do Couto e Silva, 1989.

. Origens da legislação trabalhista brasileira: exposições de motivos

de Lindolfo Collor. Porto Alegre: Fundação Paulo do Couto e Silva, 1990.

. Sinais dos tempos. Rio de Janeiro: Epasa, 1942.

COSTA, Vanda Maria Ribeiro. A armadilha do leviatã: a construção do corporativismo no Brasil. Rio de Janeiro: Editora UERJ, 1999.

CRIPPA, Adolpho. As idéias políticas no Brasil. v. 2. São Paulo: Ed. Convívio, 1979. Verbete "O Tradicionalismo Brasileiro" disponível em: $<$ http:// www.cdpb. org.br/html/ estudos_destacados_tradbrasileiro.html>. Acesso em: 3 mai 2011.

CRUZ, Justino. Legislação industrial. Braga: Livraria Cruz, 1945.

DELGADO, Mauricio Godinho. Curso de direito do trabalho. $5^{\text {a }}$ ed. São Paulo: LTr, 2006.

FALCÃO, Joaquim Arruda. Lawyers in Brazil: ideals and praxis. International Journal of the Sociology of Law, Londres, n. 7, p. 355-75, 1979.

FARIA, Anacleto de Oliveira. Democracia humana. Rio de Janeiro: José Olympio, 1958.

FARIA, José Eduardo Campos de. Papel do direito na construção do desenvolvimento.

Cadernos Direito GV, São Paulo, v. 5, n. 6, pp. 15 e 23, nov 2008.

FAUSTO, Boris. A revolução de 1930: historiografia e história. São Paulo: Companhia das Letras, 1997.

2006.

Getúlio Vargas: o poder e o sorriso. São Paulo: Companhia das Letras,

O pensamento nacionalista autoritário. Rio de Janeiro: Jorge Zahar,

2001.

FERNANDES, Adaucto. Direito industrial brasileiro. Curitiba: Editora Guaíra Ltda., 1942.

FERNANDES, Maria Fernanda Lombardi. A organização do Estado brasileiro na Primeira República. In: MOTA, Carlos Guilherme; FERREIRA, Gabriela Nunes. (Org.). Os juristas na formação do Estado-nação brasileiro: 1850 - 1930. São Paulo: Saraiva, 2010. 
FERRARI, Irani; NASCIMENTO, Amauri Mascaro e MARTINS FILHO, Ives Gandra da Silva. História do trabalho, do direito do trabalho e da justiça do trabalho. São Paulo: LTr, 1998.

FERREIRA, Waldemar. A justiça do trabalho. v. 1. São Paulo: São Paulo Editora, 1938.

Rio de Janeiro: Freitas Bastos, 1939.

Principios de legislação social e direito judiciario do trabalho.

FGV.CPDOC. A revolução de 1930: textos e documentos. Brasília: Editora da UNB, 1982.

FGV. CPDOC. Dicionário Histórico Biográfico Brasileiro: verbete Gustavo Barroso. Rio de Janeiro, 2010. Disponível em: <http://www.fgv.br/cpdoc>. Acesso em: 13 abr. 2011.

FGV. CPDOC. Dicionário Histórico Biográfico Brasileiro: verbete Gustavo Barroso. Rio de Janeiro, 2010. Disponível em: http://cpdoc. fgv.br/ producao/ dossies/ AEraVargas2/ biografias/alcides_etchegoyen. Acesso em: 29 de outubro de 2012.

FGV. CPDOC. Navegando na História - A Era Vargas: dos anos 20 a 1945, Anos de Incerteza - Polícia política. São Paulo, 1997. Disponível em: < http:// cpdoc.fgv.br/ producao/dossies/ AEraVargas1/ anos30-37/RadicalizacaoPolitica/PoliciaPolitica $>$. Acesso em: 16 out. 2011.

FGV. CPDOC. Navegando na História - A Era Vargas: dos anos 20 a 1945, Anos de Incerteza - Polícia política. São Paulo, 1997. Disponível em: < http:// cpdoc.fgv.br/ producao/dossies/ AEraVargas1/ anos30-37/RadicalizacaoPolitica/PoliciaPolitica $>$. Acesso em: 16 out. 2011

FIESP. As raízes do pensamento industrial brasileiro. São Paulo: Instituto Roberto Simonsen, 2010.

. Revista Industrial de São Paulo. São Paulo: Federação e Centro das Indústrias de São Paulo, anos 1 a 3, 1944-1946. vv.

FIGUEIREDO, Guilherme. Guilherme Figueiredo (depoimento a Rosa Maria Barbosa de Araújo, 1977). Rio de Janeiro, CPDOC. Disponível em:

http://www.fgv.br/cpdoc/historal/arq/Entrevista107.pdf. Acesso em: 27 out 2012.

FRENCH, John D. Afogados em leis: a CLT e a cultura política dos trabalhadores brasileiros. São Paulo: Fundação Perseu Abramo, 2001.

. Proclamado leis, metendo o pau e lutando por direitos: a questão social como caso de polícia, 1920-1964. In: LARA, Silvia Hunold; MENDONÇA, Joseli Maria Nunes. Direitos e justiças no Brasil. Campinas, Editora UNICAMP, 2006, pp. 379-416.

. The origins of corporatist state intervention in Brazilian industrial relations, 1930-1934: a critique of the literature. Luso-Brazilian Review, v. 28, n.2, pp. 13-26, winter 1991). 
FREUND, Julien. Sociologia de Max Weber. $5^{\mathrm{a}}$ ed. Rio de Janeiro: Forense Universitária, 2000.

GALLIGAN, Denis J. Law in modern society. New York: Oxford University Press, 2007.

GARCIA NETO, Paulo Macedo. (A questão social na Era Vargas entre a regulação de trabalho da CLT e os "fins sociais" da Lei de Introdução ao Código Civil. In: MOTTA, Carlos Guilherme; SALINAS, Natasha Schmitt Caccia (org.). Os juristas na formação do Estado-nação brasileiro: 1930 - dias atuais. São Paulo: Saraiva, 2010.

GOMES, Angela de Castro (org.). Regionalismo e centralização política: partidos e constituinte nos anos 1930. Rio de Janeiro: Nova Fronteira, 1980.

GOMES, Ângela de Castro. A invenção do trabalhismo. $3^{\mathrm{a}}$ ed. Rio de Janeiro: Editora FGV, 2005.

1917-1937. Rio de Janeiro: Campus, 1979.

. Burguesia e trabalho: política e legislação social no Brasil

Cidadania e direitos do trabalho. Rio de Janeiro: Jorge

Zahar Editor, 2002.

; D’Araújo, Maria Celina. Getulismo e trabalhismo. São

Paulo: Ática, 1989.

; PESSANHA, Elina G. da Fonte; MOREL, Regina de Moraes.

Arnaldo Süssekind: um construtor do direito do trabalho. Rio de Janeiro: Renovar, 2004.

GOMES, Orlando. Introdução ao direito do trabalho. Rio de Janeiro: Forense, 1944, pp. 195-6.

GUIMARÃES, Armelim. A morte de BG. Disponível em:

$<$ http://reocities.com/Athens/olympus/3583/victoria.htm>. Acesso em: 25 out 2011.

INSTITUTO DE DIREITO SOCIAL. Anais do I Congresso de Direito Social, mai. 1941, compilados pela Biblioteca Central da Faculdade de Direito da Universidade de São Paulo.

JESUS, Carlos Gustavo Nóbrega de. Revista Gil Blas e o nacionalismo de combate (19191923). Assis, 2011. 202 p. Dissertação de Doutorado - Faculdade de Ciências e Letras, Campus Assis, Universidade Estadual Paulista. Disponível em: http://www. athena. biblioteca.unesp.br/exlibris/bd/bas/33004048018P5/2011/jesus_cgn_dr_assis_parcial.pdf. Acesso em: 18 nov 2012.

LACERDA, Dorval. A renúncia no direito do trabalho. São Paulo: Max Limonad, 1944. da Revista do Trabalho, 1941. . Aspectos jurídicos do contrato de trabalho. Rio de Janeiro: Edição O contracto individual de trabalho. v.1. São Paulo: Saraiva, 1939. 
LACERDA, Maurício de. A evolução legislativa do direito social brasileiro. Rio de Janeiro: Nova Fronteira, 1980.

LEME, Marisa Saenz. A ideologia dos industriais brasileiros (1919-1945). Petrópolis: Vozes, 1978.

LEONÍDIO, Adalmir. Notas de pesquisa sobre a correspondência entre Alceu Amoroso Lima e Jackson de Figueiredo (1919-1928). Rev. de Hist. e Est. Cult., São Paulo, n. 1, v. 4, jan-mar 2007. Disponível em: <http://www. revistafenix.pro.br/ PDF10/ ARTIGO3.SECAO. LIVRE.Adalmir.Leonidio.pdf>. Acesso em: 23 de agosto de 2012.

LEVINE, Robert M. Pai dos pobres? O Brasil e a Era Vargas. São Paulo: Companhia das Letras, 2002.

LOBO, Eulália Lahmeyer (org.). Rio de Janeiro operário: natureza do Estado, conjuntura econômica, condições de vida e consciência de classe. Rio de Janeiro: Access Editora, 1992.

LOEWENSTEIN, Karl. Brazil under Vargas. Nova Iorque, The Macmillan Company, 1942.

LOPES, José Reinaldo de Lima. Direitos sociais: teoria e prática. São Paulo: Método, 2006.

Paulo: Max Limonad, 2002.

. O direito na história: lições introdutórias. $2^{\mathrm{a}}$ ed. São

Império. São Paulo: Saraiva, 2010.

. O oráculo de Delfos: o Conselho de Estado no Brasil-

LOPES, José Sérgio Leite (org.). Cultura e identidade operária: aspectos da cultura da classe trabalhadora. Rio de Janeiro: Editora UFRJ, 1987.

MACDOWALL, Duncan. Light: a história da empresa que modernizou o Brasil. Rio de Janeiro: Ediouro, 2008.

MACIEL, José do Rego. José do Rego Maciel (depoimento a Dulce Chaves Pandolfi, 1976). Rio de Janeiro, CPDOC, 1992. 28 p. dat. Disponível em:

http://www.fgv.br/cpdoc/historal/arq/Entrevista155.pdf. Acesso em: 27 out 2012.

MARSHALL, Thomas Humphrey. Cidadania, classe social e status. Rio de Janeiro: Zahar, 1967.

MARTINS FILHO, Ives Gandra. Breve história da Justiça do Trabalho. In: NASCIMENTO, Amauri Mascaro; FERRARI, Irani (Org.). História do trabalho, do direito do trabalho e da justiça do trabalho. $2^{\mathrm{a}}$ ed.. São Paulo: LTr, 2002.

MELLO, Leda Collor de. Retrato de Lindolfo Collor: dados sobre sua vida e sua obra. Brasília: Linha Gráfica, 1990. 
MENDES, Mauricio Matos. A experiência anarquista no Brasil: algumas anotações sobre as greves de 1917 e suas repercussões na Câmara dos Deputados. Revista E-Legis, n. 5, p. 32-46, $2^{\circ}$ semestre 2010. Disponível em: <http://inseer.ibict.br/e-legis>, acesso em 18 maio 2011.

MORAES FILHO, Evaristo de; MORAES, Antonio Carlos Flores de. Introdução ao direito do trabalho. $10^{\mathrm{a}}$ ed. São Paulo: LTr, 2010.

Paulo: Max Limonad, 1944.

. Contrato de trabalho: formas, alteração e rescisão.São

. O problema do sindicato único no Brasil.: seus

$\overline{\text { fundamentos sociológicos. } 2^{\mathrm{a}}}$ ed. São Paulo: Editora Alfa-omega, 1978.

MOREIRA, Cleiton Vieira. Revanche verde: O Partido de Representação Popular na experiência democrática brasileira (1945-1964). Anais do XV Encontro Regional de História da ANPUH-Rio, Rio de Janeiro, julho 2012. Disponível em: http://www.encontro2012. rj.anpuh.org/ resources/anais/ 15/1332851589_ARQUIVO_ Artigocleitonvieiramoreiraprp. pdf. Acesso em: 15 set 2012.

MOTA, Carolina. Brasil Under Vargas: a análise jurídica de Karl Loewenstein. In: MOTA, Carlos Guilherme; SALINAS, Natasha S. C. (org.). Os juristas na formação do Estadonação brasileiro: 1930 - dias atuais. São Paulo: Saraiva, 2010.

NASCIMENTO, Amauri Mascaro. Curso de direito do trabalho. $27^{\mathrm{a}}$ ed. São Paulo: Saraiva, 2012.

História do direito do trabalho no Brasil. In:

NASCIMENTO, Amauri Mascaro; FERRARI, Irani. História do trabalho, do direito do trabalho e da justiça do trabalho, $2^{a}$ ed., São Paulo: LTr, 2002.

NETO, Paulo Macedo Garcia. A questão social na Era Vargas entre a regulação de trabalho da CLT e os "fins sociais" da Lei de Introdução ao Código Civil. In: MOTA, Carlos Guilherme; SALINAS, Natasha S. C. (Org.). Os juristas na formação do Estadonação brasileiro: 1930 - dias atuais. São Paulo: Saraiva, 2010.

NIEMEYER, W. Curso de legislação brasileira do trabalho. Rio de Janeiro: A. Coelho Branco Filho, 1936.

NOGUEIRA JUNIOR, J. A. Anteprojeto de Código do Trabalho. São Paulo: FIESP, 1960.

OLIVEIRA, Fabiana Luci de, SILVA, Virginia Pereira da. Processos judiciais como fonte de dados: poder e interpretação. Sociologias, Porto Alegre, ano 7, n. 13, jan/jun 2005, pp. 245-259. Disponível em: http://www.scielo.br/pdf/soc/n13/23563.pdf. Acesso em: 12 dez 2011.

OLIVEIRA, Francisco Antonio de. Curso de direito do trabalho. São Paulo: LTr, 2011. 
OLIVEIRA, Lúcia Lippi; VELlOSO, Mônica Pimenta; GOMES, Angela de Castro. Estado Novo: ideologia e poder. Rio de Janeiro: Jorge Zahar Editor, 1982.

PACHECO, Jairo Queiroz. Guerra na fábrica: cotidiano operário fabril durante a segunda guerra - o caso de Juiz de Fora - MG. Dissertação de Mestrado. São Paulo: USP, 1996.

PEIXOTO, Jarbas. Código do trabalho: interpretação e prática da Consolidação das Leis do Trabalho. Rio de Janeiro: Editora Nacional de Direito, 1945.

PESSANHA, Elina; BÔAS, Glaucia Villas; MOREL, Regina Lúcia. Evaristo de Moraes: um intelectual humanista. Rio de Janeiro: Top Books, 2005.

PIMPÃO, Hirosê. Aviso prévio. São Paulo: Max Limonad, 1944.

. Despedida injusta: a lei n. 62 na teoria e na prática (comentários e jurisprudência). Curitiba: Editora Guaíra. 1941.

fev. 1942.

. Espírito do novo direito. Revista do Trabalho, ano X, n. 2, p. 11-12,

Guarany, 1942.

Getúlio Vargas e o direito social trabalhista. Rio de Janeiro: Gráfica

. Marchandage. Revista do Trabalho, ano X, n. 8, p. 10-12, ago. 1942.

RICOEUR, Paul. Tempo e narrativa. Campinas: Papirus, 1994.

RODRIGUES, José Albertino. Sindicato e desenvolvimento no Brasil. São Paulo:

Difusão Europeia do Livro, 1966.

RODRIGUES, Leôncio Martins. Industrialização e atitudes operárias. São Paulo: Brasiliense, 1970.

RODRIGUEZ, José Rodrigo. A cabrocha e o magistrado: apontamentos sobre o drama do direito no Brasil In: TOLEDO, Marleine Paula Marcondes e Ferreira de (Org.). Cultura brasileira: o jeito de ser e de viver de um povo. São Paulo: Nakin Editorial, 2004.

RODRÍGUEZ, Ricardo Vélez. Oliveira Vianna e o papel modernizador do Estado brasileiro. Londrina: Editora UEL, 1997.

ROSANVALLON, Pierre. A nova questão social. Brasília: Instituto Theotônio Vilela, 1998.

SÁ, Paulo. As organizações paraestatais. Rio de Janeiro: DASP, 1939.

SAES, Alexandre Macchione. Conflitos do capital: Light versus CBEE na formação do capitalismo brasileiro (1898-1927). Campinas, 2008. 428 p. Dissertação de Doutorado Instituto de Economia, Universidade de Campinas. Disponível em: http://www.

bibliotecadigital. unicamp.br/ document/ ?code=vtls000446813\&fd=y. Acesso em: 28 out 2012. 
SANTOS, Wanderley Guilherme dos. A Pós-“Revolução" Brasileira. In: FRANCO, Afonso Arinos de Melo. Brasil, Sociedade Democrática. Rio de Janeiro, Editora José Olympio, 1985.

brasileira. $2^{\text {a }}$ ed. Rio de Janeiro: Campus, 1987.

Cidadania e justiça: a política social na ordem Décadas de Espanto e uma Apologia

Democrática. Rio de Janeiro, Editora Rocco, 1998.

Paradoxos do liberalismo. Rio de Janeiro:

Vértice/Iuperj, 1988.

SENADO FEDERAL. Idéias sociais de Jorge Street: cronologia, introdução, notas bibliográficas e textos selecionados. Brasília: Senado, 1980.

SILVA, Fernando Teixeira da. A carga e a culpa - Os operários das docas de Santos: direitos e cultura de solidariedade (1937 - 1968). São Paulo/Santos: Hucitec/Prefeitura Municipal de Santos, 1995.

SILVA, Maria Sângela de Sousa Santos. Justiça e Trabalho: os processos trabalhistas de Fortaleza nas décadas de 1930 e 1940. Disponível em:

$<$ http://www.apeoc.org.br/trab.academico/Justica_do_Trabalho_Trabalhadores.pdf $>$, acesso em 15 mar 2011.

SILVA, Sandro Héverton Câmara da Silva. Anistia polítca: conflito e conciliação no âmbito do Congresso Nacional Brasileiro (1964-1979). Rio de Janeiro, 2007, 155 p. Dissertação de Mestrado - Instituto de Filosofia e Ciências Humanas, Universidade do Estado do Rio de Janeiro. Disponível em: http://bd. camara. gov.

br/bd/handle/bdcamara/3663. Acesso em: 18 out 2012.

SILVA, Sergio S.; SZMRECSÁNYI, Tamás. (Org.). História econômica da Primeira República. $2^{a}$ ed. São Paulo: Hucitec-Edusp-Imprensa Oficial, 2002.

SILVA, Zélia Lopes da. A domesticação dos trabalhadores nos anos 30. São Paulo: Marco Zero/CNPq, 1990.

SIMÃO, Aziz, Sindicato e Estado. São Paulo: Dominus, 1966.

SINDICATO INDUSTRIAL DO AÇUCAR NO ESTADO DE SÃO PAULO. Em torno do estatuto da lavoura canavieira. São Paulo: RT, 1941.

SKIDMORE, Thomas E. Brasil: de Getúlio Vargas a Castelo Branco (1930-1964). Rio de Janeiro: Paz e Terra, 1975.

Politics in Brazil: an experiment on democracy - 1930-1964.

New York: Oxford University Press, 1967.

SOUZA NETO, Francisco de Andrade. Da justiça do trabalho e sua organização e competência. São Paulo: Livraria Acadêmica Saraiva e Cia. Editores, 1938. 
SOUZA, Samuel Fernando de. "A questão social é, principalmente e antes de tudo, uma questão jurídica": o CNT e a judicialização das relações de trabalho no Brasil. Cad. AEL, v. 14, n. 26, 2009. Disponível em:

http://segall.ifch.unicamp.br/publicacoes_ael/index.php/cadernos_ael/article/view/51/52. Acesso em: 2 dez 2011.

Coagidos ou subornados: trabalhadores, sindicatos, Estado e leis do trabalho nos anos 1930. 2007. 228 f. Dissertação de Doutorado - Instituto de Filosofia e Ciências Humanas, Universidade de Campinas, 2007. Disponível em: < http:// cutter. unicamp.br /document/ ?code $=$ vtls000436523>. Acesso em: 16 novembro 2011.

STF. MINISTROS. Antonio Joaquim Pires de Carvalho e Albuquerque. Verbete biográfico disponível em < http://www.stf.jus.br/portal/ministro/verMinistro.asp?periodo $=$ stf\&id $=118>$. Acesso em: 04 set 2012.

SÜSSEKIND, Arnaldo. Direito brasileiro do trabalho. Rio de Janeiro: A Noite, 1943. . Jurisdição e competência da Justiça do Trabalho. Revista do

Trabalho, ano X, n. 1, p. 3-5, jan. 1942.

Manual da Justiça do Trabalho. Rio de Janeiro: Freitas Bastos, 1944. Presidente Getúlio Vargas e o Direito Brasileiro do Trabalho. Revista do Trabalho, ano X, n. 1,p. 11-13, jan. 1942.

; LACERDA, Dorval; VIANA, José de Segadas. Direito brasileiro do trabalho. v.1. Rio de Janeiro: Livraria Jacinto Editora, 1943.

SUZIGAN, Wilson. Indústria brasileira: origem e desenvolvimento. Nova edição. São Paulo: Hucitec/Editora da Unicamp, 2000.

SZMRECSÁNYI, Tamás; MARANHÃO, Ricardo. (Org.). História de empresas e desenvolvimento econômico. $2^{\mathrm{a}}$ ed. São Paulo: Hucitec-Edusp-Imprensa Oficial, 2002.

SZMRECSÁNYI, Tamás; SUZIGAN, Wilson. (Org.). História econômica do Brasil contemporâneo. $2^{\mathrm{a}}$ ed. São Paulo: Hucitec-Edusp-Imprensa Oficial, 2002.

TÉRCIO, Jason. A espada e a balança: crime e política no banco dos réus. São Paulo: Jorge Zahar Editor, 2002, p. 188.

THOMPSON, E. P. A formação da classe operária inglesa. Rio de Janeiro: Paz e Terra, 1987. $3 \mathrm{v}$.

TINHORÃO, José Ramos. Música Popular: um tema em debate. $3^{\mathrm{a}}$ ed. São Paulo: Ed. 34, 1997, $208 \mathrm{p}$.

TRENTO, Angelo. Do outro lado do Atlântico: um século de imigração italiana no Brasil. São Paulo: Nobel, 1989. 
UNIVERSIDADE DE CHICAGO. Relatório do Ministro da Agricultura, Indústria e Comércio. 1923. Arquivos Brasileiros. Disponível em:

$<$ http://brazil.crl.edu/bsd/bsd/u2019/000325.html>. Acesso em: $11 \mathrm{dez} 2011$.

Comércio. 1924. Arquivos Brasileiros. Disponível em:

$<$ http://brazil.crl.edu/bsd/bsd/u2020/000453.html>. Acesso em: 11 dez 2011.

Comércio. 1926. Arquivos Brasileiros. Disponível em:

$<$ http://brazil.crl.edu/bsd/bsd/u2022/000371.html>. Acesso em: 28 dez 2012.

VALE, Teresa Cristina de Souza Cardoso. Cidadania regulada: uma exploração crítica do conceito. In: $6^{\circ}$ Encontro da ABCP, 2008, Campinas. Anais do $6^{\circ}$ Encontro da ABCP, 2008. Disponível em: < http://cienciapolitica.servicos.ws/abcp2008/arquivos/22_7_

2008_14_35_42.pdf $>$. Acesso em 19 mai 2011.

VARUSSA, Rinaldo José. Legislação e Trabalho: experiências de trabalhadores na Justiça do Trabalho (Jundiaí-SP, décadas de 1940 a 1960). Tese de Doutorado. São Paulo: PUC, 2002.

VIANNA, Francisco José de Oliveira. Direito do trabalho e democracia social: o problema da incorporação do trabalhador no Estado. Rio de Janeiro: José Olympio, 1951.

Prefácio. In: SANTOS, Luís Pereira dos.

Consolidação das leis trabalhistas. Rio de Janeiro, 1936.

Problemas de direito corporativo. Rio de Janeiro:

José Olympio, 1938.

Problemas de direito sindical. São Paulo: Max

Limonad, 1943.

Editora Nacional, 1943.

Problemas de política objetiva. São Paulo: Cia.

VIANNA, Luiz Werneck. Liberalismo e Sindicato no Brasil. Rio de Janeiro: Paz e Terra, 1976.

VIEIRA, Evaldo Amaro. Oliveira Vianna e o Estado corporativo: um estudo sobre corporativismo e autoritarismo. São Paulo: Grijalbo, 1976.

WEBER, Max. Economia y sociedade. México - DF: Fondo de Cultura Economica, 1996.

WEID, Elisabeth von der. A expansão da Rio de Janeiro Tramway Light and Power ou as origens do "Polvo Canadense". Fundação Casa de Rui Barbosa, Rio de Janeiro.

Disponível em: http://www. casaruibarbosa. gov.br/ dados/ DOC/ artigos/o-z/

FCRB_Elisabethvonder Weid_Expansao_RiodeJaneiro_TramwayLightandPower.pdf.

Acesso em: 27 out 2012. 
ANEXO A- Peças selecionadas do processo n. 1.370/1934 - “Eugenio D'Alessandro reclamada contra a Caixa de Aposentadorias e Pensões das Companhias Light, Jardim Botânico e S/A Du Gaz" 
A.1 Arrazoado de defesa de Eugenio D’Alessandro

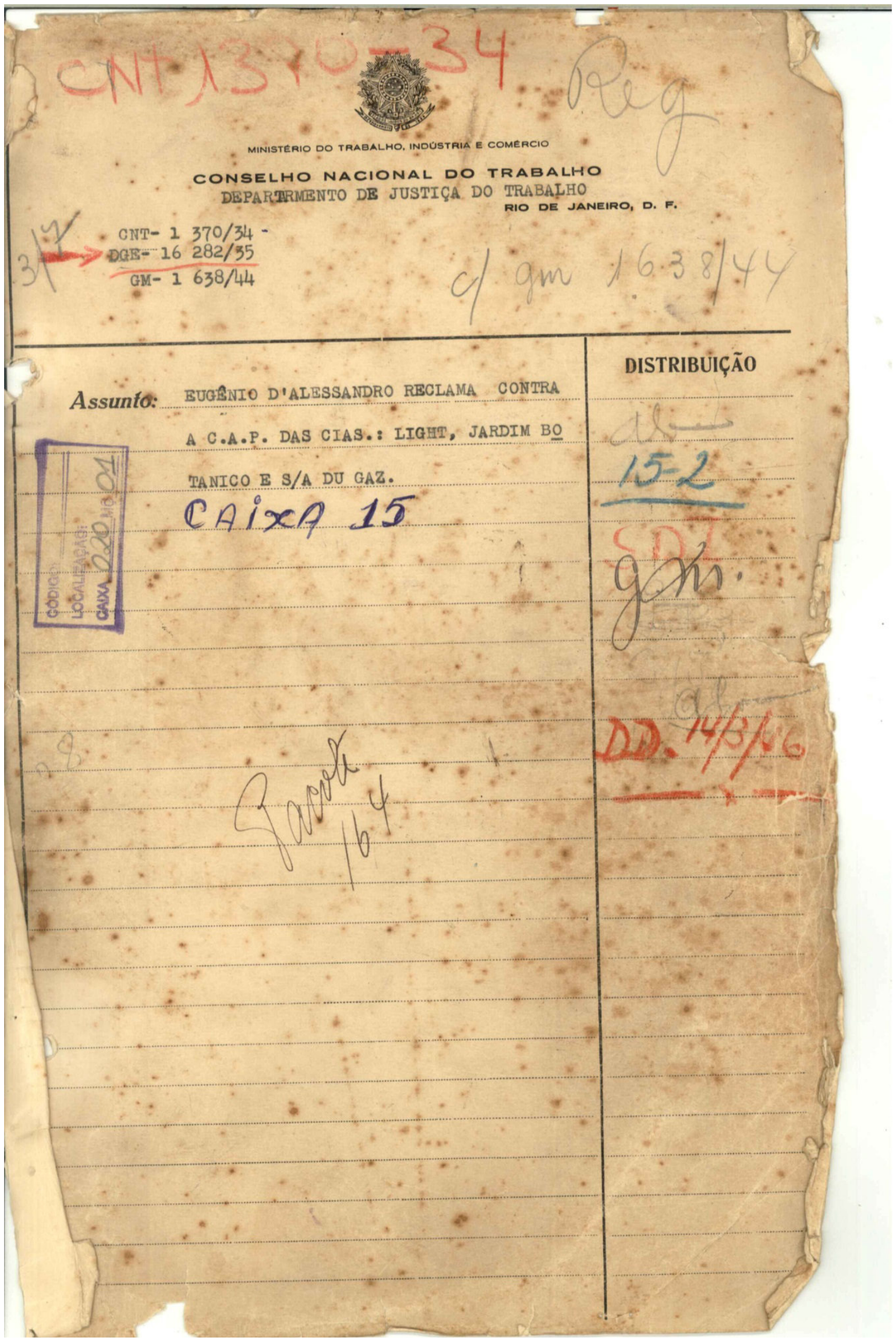




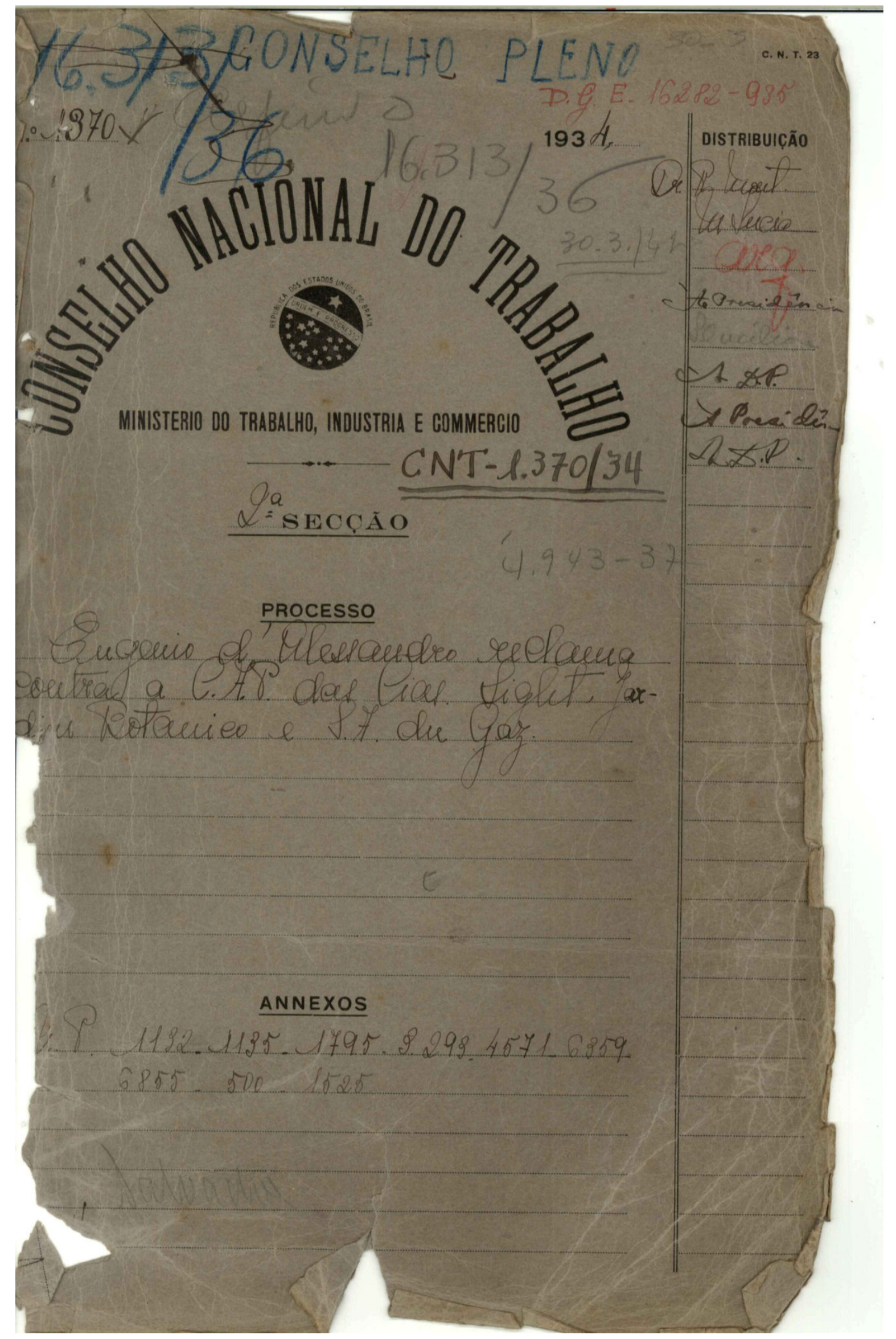




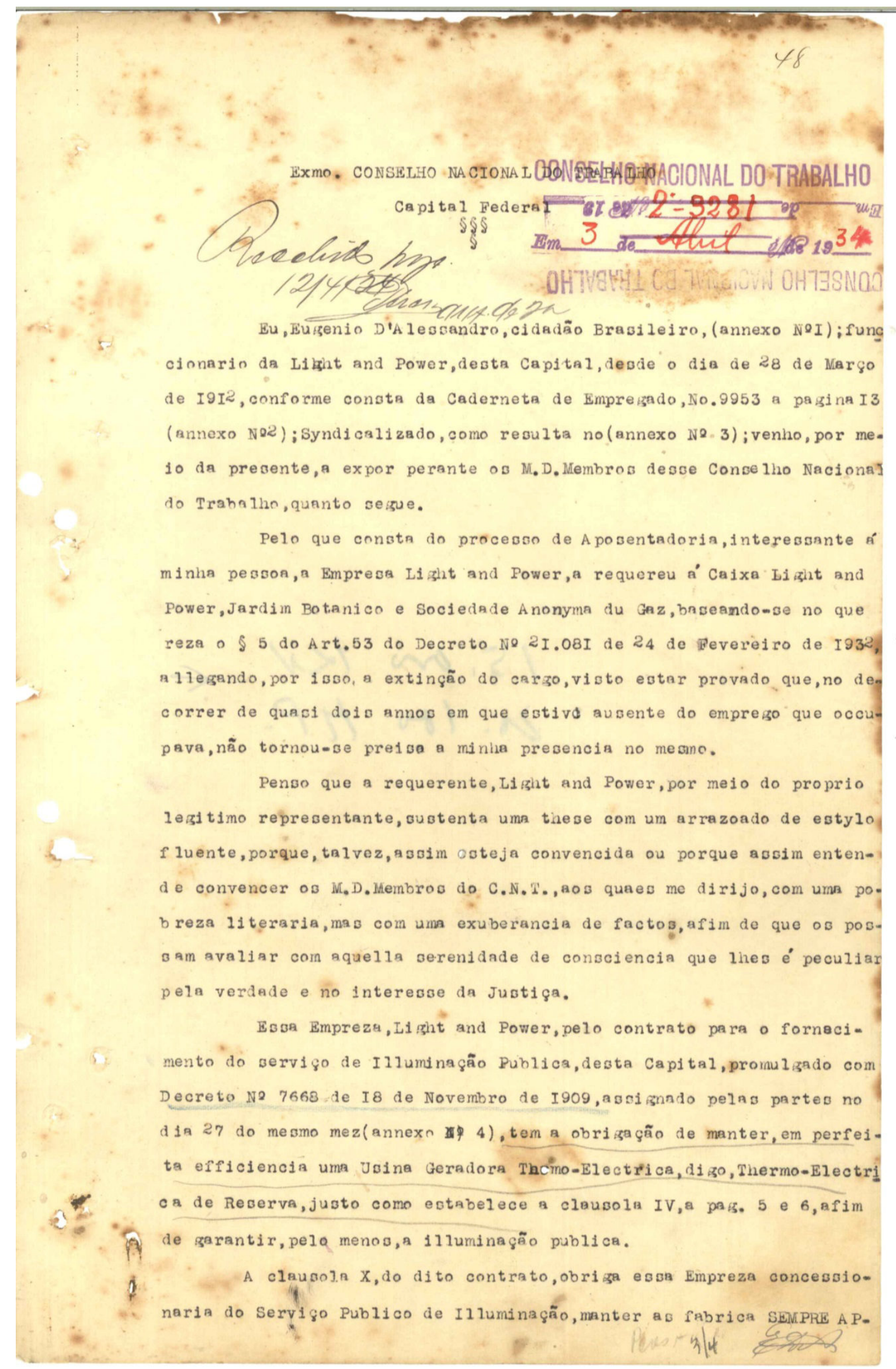




\section{$-2$.}

PARELHA DAS; e conforme a clausola XIX, a pagina I4, ella está obrigada manter, tambem, de PRONTIDÃO o pessoal necessario ao respectivo serviço de re* paro, conservação, substi ți ção etc.

Dado o qualificativo de USINA DE RESERVA, esta pode afigurar-se uma Instalação decorativa, ou tha instalação montada por um excesso de precau६̊̃o: no entanto, desde o dia em que foi completada a montagem da primeira unidade Thermo-Electrica,em Feveeiro de I9I2, essa Usina funccionou, gerando energia electrica, innumeras vezes, por annos inteiros,mezes,dias e horag,afim de supplir a deficiencia da energia Hydro-Electrica, por circumstancias diversas,como seja: Incidente nas Usinas geradoras ordinarias nas linhas de trangmissão;nas obras de represa e por disturbios politicog

Egsas caugas mencionadas, se apregentaram sempre de gurpreza, e por 1 sso, a Ugina Thermo-Electrica de Reserva, recebia o pedido de soccorro, com a maxima urgencia,afim de entrar em pleno funccionamento; cupplir as necessidades do momento, e manter inalterado o servi ģo de Illuminação,

A. Usina em aprego, está apparelhada, no presente momento, para zerar I $5.000 \mathrm{~K} . \mathrm{W}_{.} \mathrm{H}_{\text {. }}$ portanto a parte thermica é de $20.100 \mathrm{H}$. P., sendo constituida, por Turbinas;aparado Condensador;caldeiras;bombas de alimentação; bombas de oleo; bombas de elevação;bombas refrigerantes,etc.

Não devo ajuizar eu, que sou parte em cauga, qual o numero de funccionarios especializados, que semelihante instalação requer, não só para satisfazer o espirito e a letra da clausola XIX da par.I4 do contracto (annexo Ne4) mas tambem para satisfazer ás necesoidades funccionaes da dita Usina; certo é, que não se pode prescindir dos MACHINISTAS, maxime de quem $e^{\prime}$ machinista legalmente autorizado exercer essa profissão, (annexo $N^{2} 5$ ).

Afim de opinar com acerto, e esquivando os sophismas, oos quaes recor, re quem não possue argumentos de valor, é indispensavel saber, pelos meios 31 nvestigativos: Quaes são os empresados adicto nesga Usina, nominalmente; qual é a respectiva funç̧ão; se elles estâo habilitados e leģalmente auto. rizados exercel-a; se ha funccionarios treinados e capazes a attender aos reparos, conservação e substituiçẽo; resalvando o direito de preferencia - que a Lei concede aos cidadôes Brasileiros.

A Ha nessa Usina Thermo-Electrica, um Chefe que responde ao nome de John D. Nurray, o qual como se vé é inglez,que abbandonou a Empreza em I9I5; foi

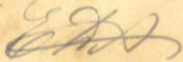




\section{- 3 -}

readmitido em I9I8, pedindo demissão nesse mesmo anno; voltou novamente em I 92 I; foi trangferido para S.Paulo em I924, de onde regregsou, para a Usina de Reserva em I6 de Dezembro de I926, reassumindo a Chefia desse Esta. ६̧ão, conforme, em parte é provado no(annexo No 6), constituido por uma publı c a forma de'um offtcio traduzido, do inglez para o portuguezadirigido ao Superintendente do Departamento Electrico,Sr.J.H.Smeaton, pelo Superintendente da Divisão da Producção de Electricidade Sr.A. Borgertì.

Egere vae e vem, pode ser averiguado, por meio da reopectiva caderneta de empregado ou pelo tempo averbado na Caixa de Aposentadoria, unicamente para ficar sciente da instabilidade desse Cuefe que nẽo se pode recomendar para attender ás emergencias do servígo de Illuminação Publica, d e que a Light é concessionaria, e ao qual, a população desta Capital ètá Bujeita.

Mesmo no goso de ferias,o Chefe da Usina Thermica de Réserva, vae para a Englaterra, augmentando assim de facto, a sua augencia desta Capital

Para apresentar, o panorama das circumstancias, que em nada justifi. c am ou reforçam a pretenção da requerente, lembro que por ter sido trana ferido, para S.Paulo o citado Chefe,J.D. Murray, e em vista de ter ficado, e u, sosinho, e unico habilitado a movimentar a instalação da Usina ThermoElectrica de Reserva, e considerando que, em caso de emergencia, nẽo podia fioar ininterruptamente $a^{\prime}$ testa do serviço; a Empreza Light and Power,contratou, e lhe deu o emprego, conforme se nota nol (ennexo Ne 7 ) wo Sr.Willia Fairlam, conferindo-1he as atribuições de ENGENHEIRO DE MACHINAS A VA POR; a tribuições estas, que merecem serem examinadas e aquilatadas em relação a o gráo de habilitação e se está legalmente autorizado exercel-as.

No dia I3 de Dezembro de I926, a Usina Thermica de Reserva, recebeu, como sempre, ordens para entrar em pleno funccionamento, com toda urgencia, - gerar energia electrica,de 6 a 2 I horas.

Qualquer individuo, mesmo prophano da materia e do serviço de ope$r$ ação de uma instalação de machlnas a vapor de 20.100 H. P., comprehende que nesse limite de actividade effectiva, era,como é, e será preciso, de uma preparação, e effectuar os reparos que se tinham tornados necessarios e vemificados, nas machinas em funç̧ô, no decorrer do dia.

Não obstante que, o chamado Engenheiro de Nachina a Vapor,William Fairlam, ja' contagse com I8 mezes de permanencia nessa Usina, se revelou, cos 
nessa emergencia, de $\not$ uma $i$ morancia absoluda, constatada por outros Superiores,os quaes decidiram chamar, de S.Palo o Sr.J.D.Murray, considerando que existia uma sobrecarga de serviço, e que eu devia arcar, pelas circums tancias do momento.

Nãó foi so deşa vez, que a Uaina Thermo-Electrica de Reserva, foi precisa com urgencia, mas ellas foram numerosas, e no intuito de exclarecer os M.D. Membros do C.N.T., de, quando uma instalação desse genero e importancia é mantida por longo tempo em repouso, pode provocar lançes dramaticos, provocados ou pelos pretenciosos, aos quaes thes se apresenta a o ccasião de provar a respectiva habilitação, ou occasionados por circumstancias independentes da propria vontade, das quaes so triumpha, quem pog s ue as qualidades necessarias, fructo de uma longa experiença e dedicaçâ ao serviço e á profişão, 1 embro que em II de Dezembro de I920, esta cidade ficou sem luz e for çâ I4 h. e 44 minutos, alterando sensivelmente a vida normal da população; e apezar que essa Joina estivesse,nesse dia, em e speciaes condições, unicas desde a sua existencia, podendo fornecer energia electrica em meia hora, foram precisas tres horas para que o primeiro gerador pudesse ser ligado nas linhas de distribuiģão,e isso, so se verificou quando eu cheguei na estação a tomar conta da situação, embora esti vessem presente outros machinistas.

Refiro 1 sso, pela verdade e pela historia dos factos,os quaes na Empreza Light and Power, muitas vezes, são torcidos e deturpados por conv eniencias pessoaes.

No mez de outubro de I930, devido a disturbios politicos, conhecidos por, Revolução de Outubro, a Usina Thermo-Electrica de Regerva, fol chamada com urgencia, pelo facto de que, a importante Usina Hydro-Electrica de Parahyba, tinha cahida na mão das forças revolucionarias,impedindo de transmitir energia electrica para esta Capital.

Deixo de referir,em quaes condições se encontravam, outras Usinas Hydro-Electricas, como por exemplo a de Ribeirão das Lages, que embora vigiadas por forças de polticia, não excluia a possibilidade de cahir nas maōes das forças revolucionarias; por isso, com indiscutivel criterio,o contracto, (annexo Ne 4) incluiu as clausolas por meio das quaes é impos ta, á Empreza Li ģht and Power, a perfeita conservaçã e manutençã (materià e funccionarios)dessa Usina de Reserva.

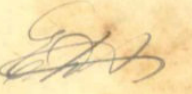




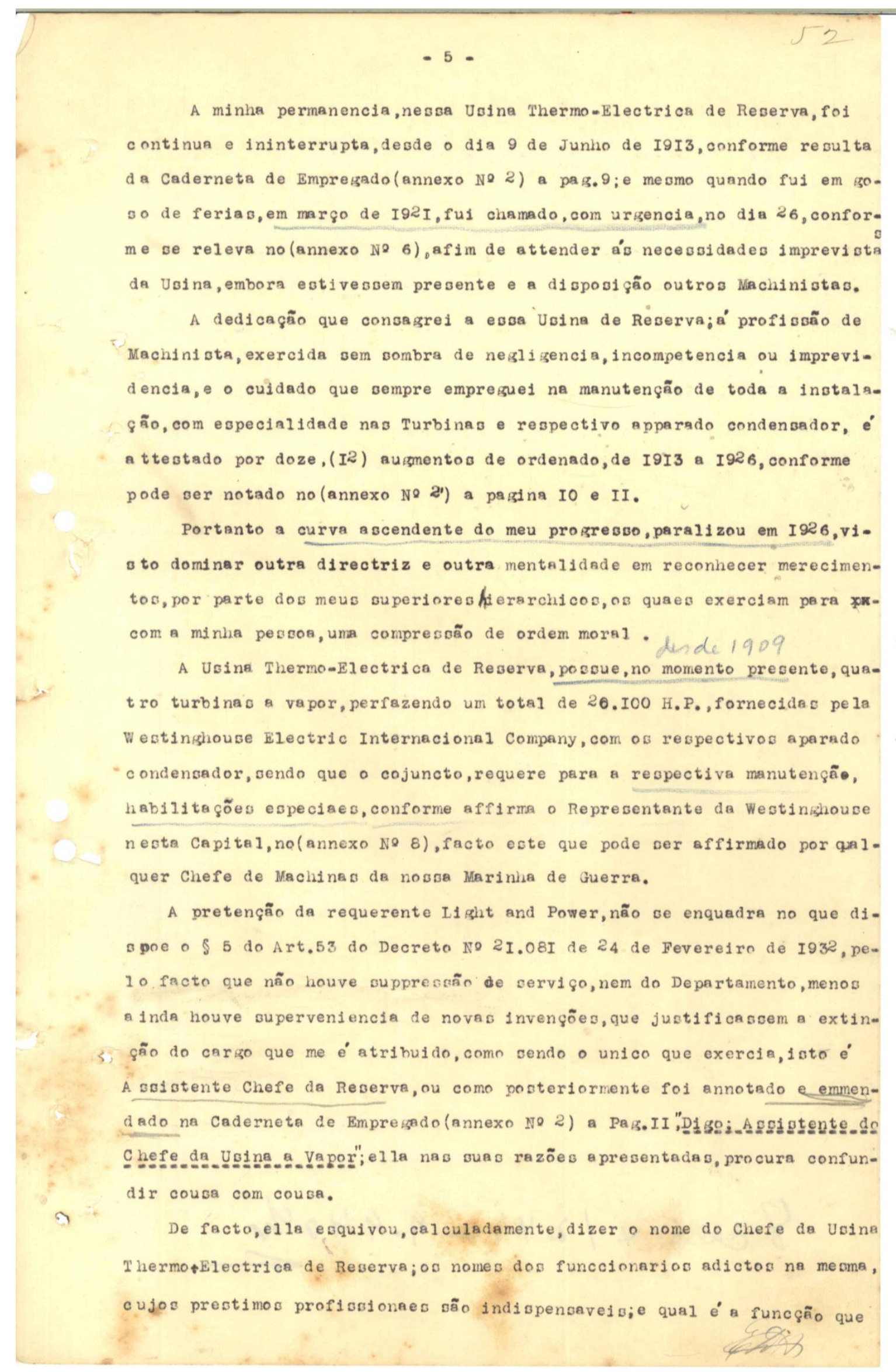


$-6$.

cada qual exerce; e afim de equivocar, diz que a "opperveniencia de novas I nvenções" consiste em ter gido instalado na Ia. bateria de calleiras,um novo systema de combustão a oleo, que veiu a reduzir e simplificar o serviço; omitindo o nome do technico que affirmou isso.

Fa ço observar aos B.D. Membros do C.N.T., que nessa Usina Thermo-Electrica de Reserva, como em qualquer autra instalação em que se utiliza, como força motriz, a energía thermica, existem os aserradores de vapor, que ธão as caldeiras, cuja fonte de calorias é dada pela combustão do carvão, do oleo ou de qualquer outro corpo combustivel; e nesse serviço são empregados os FOGUISTAS.

Quero acreditar que 1 sso fol apena uma simpleo divagąa de quem escreveu as razões apresentadas, e não de um technico, não so pelo facto que em todo o dizer se nota uma preoccupaçâo de empilhar phrases, tentand o,com essa gimnastica literaria, demonstrar o que nâo é posoivelicomo de facto, as minhas funç̧ões não eram a de FOGUISTA, e sim de MACHINISIA ou mesmo" STEAM ENGINEER", qualidade maxima e suprema de quem se destina $a^{\prime}$ - peração de toda a Instalação thermica; de quem é responsavel pelo perfelto funccionamento da mesma; e de quem é penalmente responsavel pela Incolumidade dos funccionarios dependentes, com especialidade dos que são empregados ao serviço de foßuistas, nas caldeiras.

A qualidade profiasional tha que eu exercia,de facto, é affirmada pelo Superintendente do Departamento Electrico,Sr.J.H.Smeaton e pelo Sr. Superintendente da Divisão da Produç̧ão de Energia Electrica,A.Borgerth em um AVISO (annexo Ne $2 I$ ); e reaffirmada, frizando ainda que eu exercia outras funçõeg technicag, $\mathrm{em}$ um officio dirjgido pelo superintendento A . Borgerth, ao Superintendente do Departamento Electrico, J.H. Smeaton(annexo No 6); e seja em um, datado em I925, como no outro, datado em I930, está 5, expressamente declarado que eu era o ENGENHEIRO DE MACHINAS A VA POR;e por essas qualidades profisgionaes era considerado, para todos os offeito o substitudo, KX ou o ASSISTENTE DO CHEFE DA USINA A VAPOR, "natural" e i nsubstituive1....

Não querendo dejxar nenhum ponto, vi oado pela requerente, envolto em neblina, esclareço que a Ia,bateria de caldeira da Usina thernía, é composta por 8 Beradores de vapor, de I243 I.P. cada um, já em precedencia, possuia a instalação para combustão a oleo, a qual, embora de systema anepros 
tigo, serviu nas occorrencies; e com esse instalação estavam treinados os foguistas da Ucina Thermica, por um espaço de 20 annos;e nessa condiça a vißjlancia dos Machinictas não era tâo severa. !

Com a nova instalação, a que se refer a requerente, como sendo uma das causa que aconselha a extinçâo do luizar de Assistente do Chefe da Usina a Vapor de Reserva, se quiz alcançar um objectivo technico e economico. Technico, para conseguir uma mals perfeita combustão; Economico, pelo resultado dessa perfeita comhustão, por melo da qual se abtem um melhor -

coeficiente de calorias utilizadas e dadas pelo combustivel,

Tambem na 2a.bateria de caldeiras, composta de SEIS geradores de

vapor XX foi instalado, de recente, o systema de combustão a oleo,em substituição da combustão a carvão, e o conjuncto, possue orga ôs delicados, e a respectiva operação requer cuidados especiaes;e por ser nova, com dif ferente disposiça etc.os Machinistas, quero dizer os responsaveis,deverão exercer, quando a Usina funccionar, uma visilancia mais rigorosa e mais activa; Portanto não é o caso de se acreditar, profissionalmente falando, que a nova insta lação de combustão a oleo, aconselhasse dđhinujr o numero de Foguistas, quanto mais dos Machinistas.

Em todo caso,a lista dos empregados nessa Usinà Thermica, e a re-

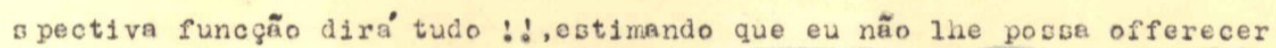
c ontesta ção.

O outro ar sumento, apresentado pela requerente, Ii ght and Power, por meio do qual declara que em 1924 fol instalada uma outra Usina HydroElectrica, por 1sso, conforme ella diz, está dimtnuida a possibilidade de se recorrer ao auxilio da Usine Thermo-Electrica, merece a minha natural contectaçẽo.

Nesmo depois de ter sido instelada essa Usina Hydro-Electrica, conhecida por:Usina de Parahyba, a Uaha Thermo-Electrica de Reserva, teve a necessidade de funccionar numerosas vezes, em periodos de tempo, que variaram de horas a de semanas; 1embrando o de Dezembro de I926 e o de Outu. bro de I930; sendo o primeiro occasionado por um incidente nas obras de represá dos reservatorio de agua,e o segundo por ter cahido esga Unina nas mañes dos revolucionarios, como lembrei antes.

Essas, como qualquer outra occorrencia imprevista, poderá sempre determinar o immediado pedido de soccorro da Usina de Reserva, a qual é re. 


\section{Cona Gecentios}

serva, exactamente por isso; portinło a sua perfeita conservação e respectivo aperelhamento, incluido os seus funccionarios, é exigida por meio de un contracto(annexo Ne 4); e nas emerpencias,isto é, quando é preciso, de facto, toda a efficiencia dessa estação, nenhuma literatura vale, mas o que se torna indispensavel são of funccionarios habilitados, cousa que se ve* rifjcou numerogas vezed,e nessas occasiōes o chamado ASSISTENTE DO CHEFE DA USINA A VAPOR estava no seu posto de responsabilidade, meter em moímmento a instelação, enquanto o CHEFE vagava, lonßse e mujto longe do lugar. Effectivamente esse Chefe,o qual responde so nome de J.D.Murray, desde o primeiro mez de I927 desempenhou o encargo de Inspector dos extintores de incendio, instalados nas dependencias do Departamento de Electricidade,as quaes se extendem fôra desta Capital, funç̧ões que serviam para justificar e accumular ordenados.

Desga epoca, I 27, a Usina Thermica de Regerva,alem de ter funccionado para o fim a que está destinada, os respectivos funccionarios, eu encluido, foram utilizados em Derviços de construcões, como por exemplo, a sub stituição do systema de conbustão das duas baterias de caldeiras;serviços de conservação geral; e effectuados reparos ás turbinas e aparado condensador; sendo que wrax esses trabalhos eram exectiados sob a minha direção e responsabilidade.

O Chefe,empregava as suas qualidades, não na Usina Thermica de Reser va,e sim, como ja' dissi,e como o confirma no seu arrazoado o representante d a Light and Power;qualidades e atribuições que pode muito bem desimpenhar um individuo que não tem prof1ssão.

Em todo caso, mesmo os prophanos, podem ajuizar, se é mais importante o serviço de construç̧ão, conservação e reparação, de que a Usina Thermica de Reserva carecia, ou o serviço de inopeção dos apparelhos extinctores ₹ de incendio, que por sua vez era reduzido a verificar se elles estavam em 1 ugar conveniente; se estavam cheios fo liquido ou do material indicado; em summa era uma vida divertida e viajante... a qual so ers estorvada, quando a Usina Thermica de Reserva precisava funccionar por mais de oito horas, e neste caso, o Chefe, J.D. Nurray assumia a direç̧ão de uma "guarda" e eU,ASSISLENIE DO CHEFE, (usando"ad 1iteram" a expressâo)asßumia a dire§̧อ̃o da outra "guarda" successiva; com as mesmas respongabilidades e com as mesmas atribuições de commando.

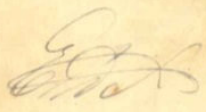




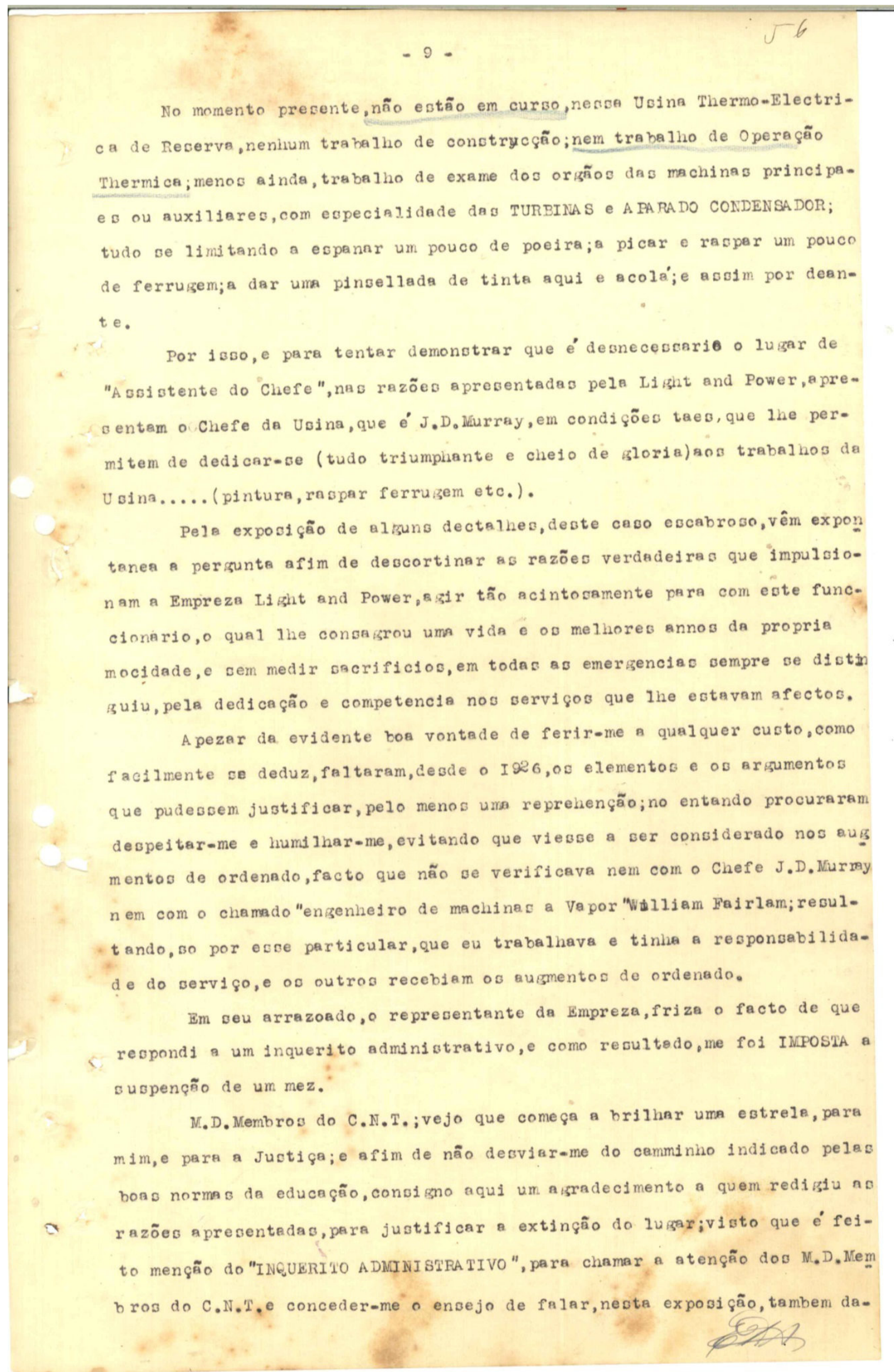


quella grande peça de architectura, na qual nẽo deslumbam, nas suas linira - estylo "Dorica-Romana" nem o "Dorica-Greca "e sim a myotificação;a infamia;a falsidade e uma desconnexa inconoludencia.

Em 7 de Maio de I932, os Empreagados da Empreza Li ght and Power, se declararam em greve(deixo de analizar os precedentes), e nesse dia, por minha infelicidade, estava doente e accamado afim de debellar uma grippe que me mantinha em estado anormal, já a alguns diab, como ficou cabalmente provado no dito inquerito;mas a coincidencia serviu para que os meus amaveis detraotores, dessem expanção á sede de vingança,por isso, como medide preliminar, fui suspenso do serviço, com toda severidade e com as necessarias insinuaçōes, as quaes não medraram nem no inquerito policial. So no dia I8 de Outubro de I932, quasi seis mezes depois, fui chamado a responder no inquerito adminiotrativo, na qualidade de accusado, conforme resulta do(annexo Ne $9^{\prime}$ ) e soube, pela leitura da denuncia dada pelo Superintendente Geral da Light and Power,Sr.J.M.Bell, que era accu-

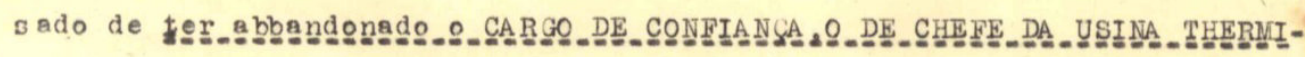
CA_DE_RESERVA dando cauga a gue egta Companhia pudegge faltar ao cumprimento.de.guas_obríga m inadamente a que a popula cão degta Cap1tal Federal fogge privada de for g. a luz e trangporte.

E,os engraçados architectos, duvidando da resistencia, procuraram

melhorar a bage.....exraxz cuidador que se trangformou em um verdadeiro

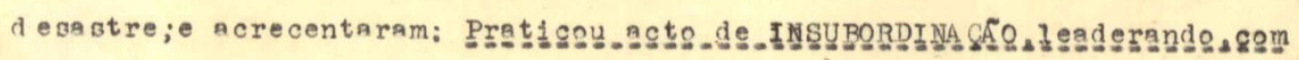
t erceirog \&.movimento grevigta de ? de Majo.do_corrente.anno encarregan-

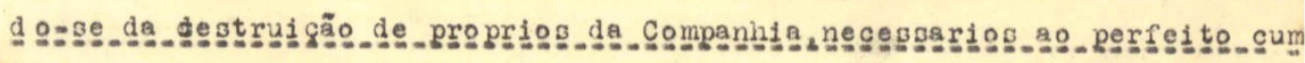
primento das guag mencionadas obri ga cõeg de concegsionaria de gervigos de utilidade publica.

Notei, gem grande esforģo, que toda esga austeridade, sobretudo, austerldade linguistica, era apenas uma" mise-en-scene" de uma commedia comica, na qual foram esçolinidos,actores apropriados, conforme o criterio. dos citados architectos, como por exemplo,os meus detractores, A. Borgerth; J.D. Murray, ambos meus chefes;e o Engenhelro de Machinas a Vapor,William Fafrlam, os quaes desimpenharam fracamente a parte que se propuzeram representar com brilho.....

A esta phalange de, homem não, de individuos, se junctou um"cuidado" है। 


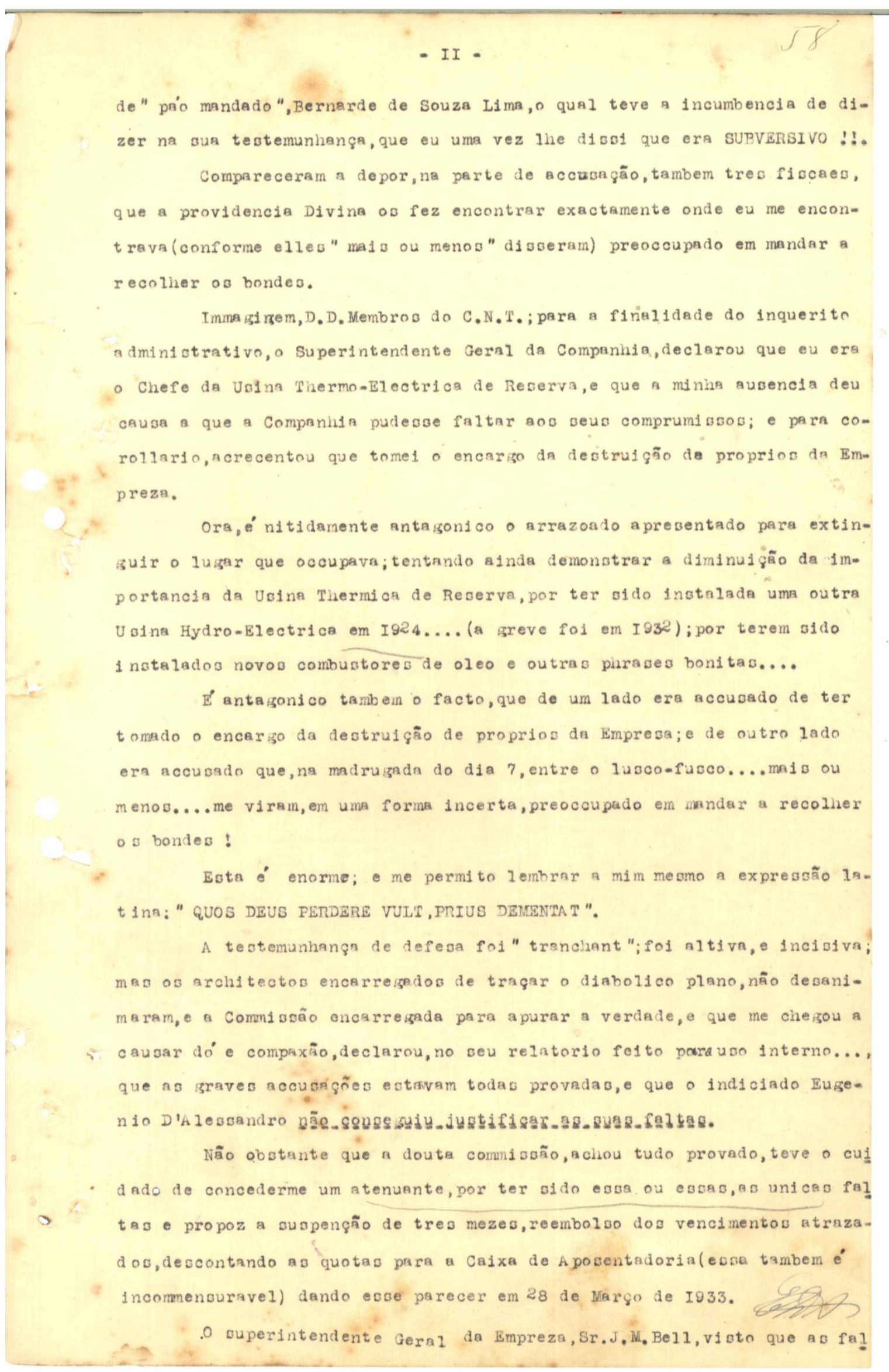




\section{- I2 -}

tas atribuidas estavam EM PARTE provadas, mas atendendo que em "seu favor" MILITA a circumstancia attenuante de hom comportamento anterior," resolve reduzir a punı̧̧̄̃o a UM MEZ DE SUSPENÇÃ "

Esse historia teve fim em I7 de Abril, depois de ter decorridos quasi I mezes, betendo o "record" do processo Dreyfus !

Recusei, com desdem, essa artimanha que representava um ultrajo ao Governo Provisorio do Brasil; $\mathbf{A}^{\prime}$ Leis trabalisistas por Elle promulgadas e A civilização de um povo, quando ouvi a leitura do ridiculo libello e a sentenģa misericordiosa do Superintendente Gera1 Sr.J.M.Be11,0 qual, ta1vez em boa fé,foi levado a mergulizar as suas maões na 1 ama pestilente da intriga, da calumnia e da vingança, para com um funccionario exemplar que dou á Light a flor da sua mogidade.

Fixei esse protesto, em um folino de papel com tinta indelevel, como $u$ m degafio; por isso em 3 de Abril de 933 , com Registrado No 59.884 da Suc. curgal do Correio, Ne 7, o remeti ao precitado Superintendente Geral, cuja copia mimeogrepiada resulta no(annexo Ne 24)

Com data de 6 de Abril, recebi uma carta Registrada ao Ne 24.810 na Succursal do Correjo" D. Pedro II", com RECIBO DE VOLIA!, por meio da qual o Secretario da Commiscão de Inquerito, me transmitiu o "ultimatum", avisando-me que a quantie, representada pelo saldo em meu favor, ostava a minha di sposiçêo..... (ou cré ou morra...) (annexo N\&2z).

Em 8 de Abril com Registrada No 4.628 effectuada na A gencia Postal d a Rua do Senado, pedi exclarecimento, sobre esse "ultimatum", por meio do qual fazia suppor que alem do mez de suspenção, havia outras consequenc 1ิธ a sofrer;mas com ca culade premeditação, não recebi resposta.

Fui convidado a uma conferencia com o consultor juridico da Empre. za,Dr.Alcebiades Delamar, cujo resumo está fixado em um telegramma que re. meti ao Sr.Superintendente Geral(annexo No IO) de onde se releva a promeg sa da possibilidade de conceder-me a revisâo do inquerito o cancellame to da "nota".

Na ausencia do citado Superintendente Geral, J.M. Bell, de viagem para a America du Norte,ficou assentado de me apresentar todos os mezes a receber o meu vencimento integral; sem nada revelar-me, megmo a meu pedido, sobre a minhaigituação : Licenciado, em disponibilidade, em ferias, ou qualquer outra novidade. No entanto, nesse mysterio, descobria alguma outra tentativa de eliminação, e fiquei vigiante e esperançoso nas Lejs buth 
do Peiz.

De facto o peigamento era feito pela megma Folha de pagamento $a^{\prime}$ qual pertencia $(E-2)$, com o mean typo de cartão(annexo No IZ), com a respectiva publica forma(annexo $\mathbb{N}$ I3) e recibo de Luz e Gaz para empregado (annexo Ne I4).

No mez de Agosto substituiram o typo do cartão de pagamento, como se vé no(annexo N2I6), com os dizeres constante do(ånnexo Ne I?) ao passo que no recibo de Luz e Caz,o desconto é feito na Folha Ež, e a quitação $e^{\prime}$ dada como se o desconto tivessie sido effectuado na Folia $\mathrm{A}-30$, conforme resulta do recibo(annexo Ne I5).

Só em Novembro, proximo passado anno, foi uniformizado o desconto de Luz Gaz(annex N2 I8) de accordo com a nova Follha de pagamento A - 30 como resulta do novo týpo de cartão(annexo Ne IB-bis), o qual pelas informaçẽes que tive, na pagadoria, é dedo aos empregados "despedidos",ou consirados taes.

Para receber o meu vencimento, era preciso posouir uma "memorandum" fornecido pelo Departamento de Empregados,conforme os (annexos NNe I9 e 20) escriptos em lingua inglez, e entregal-o ao Chefe do Departamento do ponto,o qual providenciava, no momento, fazer as contas e pasar o cartão ou "vale" da quantia resultante do saldo.

Portanto não fui eu a querer que a Lijht and Power me pagasse sem The prestar nenaum servigo, como silenciosamente é insinuado nas razões a presentadas, para extinguir o lugar...p pasando a frizar (por minisa sorte) de ter eu respondido a um inquerito administrativo, fazendo deduzir claramente, que a não reintegração;o paigamento dos vencimentos sem preotar serviço(icso para humilhar-me) e a pretega de extinção do lugar é tudo uma consequenc1a das fa1sas accusações; da mise-en-scene do famoso e ver so inquerito e da mystificação do relatorio da miseravel Commisgão de inquerito.

E no arrazoado apresentido pela Light and Power, pergunta com emphase, quem o escreveu, PORQUE DEVEMOS CONTINUAR A PAGA-LHE OS VENCINENTOS SEM PRESTAR NENHUM SERVIÇO ?

A resposta me se torna facil e é a deguinte : PARA ME INDEIRNIZAR DO MAL FEITO, E PELA ARBITRARIEDADE PRATICADA, EM NEU PREJUIZO NORAL E HATERIAL.

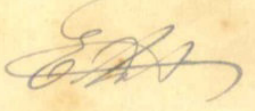


Afım de requerer a revisão do inquerito, ped1 copia por certidão do relatorio da Commissão de inquerito,e me fol respondido(annexo Ne II) que - meu inquerito estava archivado e não era possivel fornecer-me copia da peça, pelas razões já explicadas .....Em summa se esquivaramocom uma evasi. $v a$, fornecer-me uma peça secundaria, immaginem se tivesse pedido os autos de todo o inquerito, o qual conforme consta, não sairã dos muros da Li ght a qualquer custo.....

$O B$ esforços da Empresa Li ght and Power, convergem para demonstrar que nâo é mais preciso manter, na Usina de Reserva,o lugar de Assistende do Chefe;uma função decorativa;um paragsita em summa,tendo em victa a posgivel confugão(alho com bucaliho) da nova Usina Hydro-Electrica(nova de I924),com o serviço de Inspeç̧ão do apparelhamento de extinctores de incendio, que nenhum ponto de relação ha, com a Usina Thermo-Blectrica de Reserva, a qual deve ser RIGOROSA MENTE MANTIDA e DIVIDANENTE A PPA REIHADA, com FUNCCIONARIOS NECESSARIOS, etc. por força de um contracto com o Governo.

0 que a Light deve provar,é se pode extinguir o luzar de MACHINISIA ou mermo o de ENGENHEIRO DE MACHTNAS A VAPOR, conforme as minhas verdade1$r a s$ funç̧ôes que de facto exercia e affirmadas nos(annexos NNe. 6 e 2 I; - resto é literatura; são phrases alinhavadas para estabelecer confusão. O Superintendente da Divisão de Producção de Energia Blectrica e - Euperintendente do Departamento Electrico, por meio de um AVISO (anexo N 22 I ) em data de I2 de Janeiro de I925 declara, que na ausencia do Sr.J.D. Murray, Engenieiro Chefe da Usina a Vapor de Reserva, e Sr. Bugenio D'Alesg andro, ENGENHEIRO DE NACHINAS A VA POR assumirá o cargo de Encarregado de sa Usina. Como se vé, era Engenheiro de Machinas a vapor, e legalmente au. torizado exercer logalmente esgas funç̧ões conforme o(annexo $N^{2} 5$ ). 0 megmo Superintendente da Divigão de producção de Energia Electrica,dirigindo um officio ao Superintendente do Depertamento Electrico,em Fevereiro de I930(annexo Ne 6) recomendando o despacho favoravel a um meu pedido de ferias, reaffirma as minhas qualidade de Enzenheiro de Machinas a vapor;analiza a minha brilhante fé de officio;lembra que de I024 até o mez de Dezembro de I926, estive á testa da Usina de Reserva, na ausencia de J.D. Murray; lembra ainda que mesmo quando eu estivi om goso de ferias no a nno I92I, e tendo aido preciso os meus prestimos profisoionaes, fui chamado ao serviço, depois de ter gozado apena Io dias de feria. 
o mesmo superintendente,jembra nesse officio que eu possuo as qualidades necessarias,o conhecimento do conjuncto da instalação das turbinas da Usina Thermica de Reserva, a qual é ciramada a funccionar a intervallos e frequente etc.

Portanto,D.D. Nembros do C.N.T. não é com um grosseiro artificio ťx que se podem destruir factos documentados.

Na propria Carteira de Empregado, (annexo No.2) de nota, á pagina IO, na columa destinada a serem annotadas as promoçôes e novas occupaçōes, se vé que em I924 já exercia as funeçōes de ENGENHEIRO USINA RESERVA - em I926, IQ de Setembro, fui "promovido" a "A soistente do Chefe da Usina a Vapor"; quer dizer que quando o Chefe estava nesiga Estação eu era o Engenheiro de Machinas a Vapor, ou simplesmente Condưctor de Naclinas a Vapor - quando esse chefe resiedia em S.Paulo a mais de um anno, eu era o Asig tente delle...

Quando o Sr.J.D.Murray, em I929, foi de ferias para a Enß̧̧aterra, eu tive o encargo de assumir o activo e pascivo desga Estagão, era o herdeiro natural; o substitudo insubstituivel(quando a Usina deve runceionar de contrario qualquer varredor pode tomar conta)e mesmo assim, se tornou preciso o AVISO(annexo No 22).

Os M.D. Nembros do C.N.T., sabem perfeitamente, que onde ha numerosos individuos, e onde ha responsabilidade para assumir, existe uma hierar. chia por meio da qual são distinguidos elementos que compoem a entidade, com especialidade os elementos de commandos a cujas determinações, e direc triz,og demais devem obedecer,fixando a cada qual as atribuições e responsabilidades.

Por esta ordem de principio, ha Generajs,Coroneis,Capitaeis, Tenen. t es etc. assim nas Emprezas Industriaes, ha Superintendentes, Chefes, ASSI * STENSE DO CHEFE, Feitores, Capataz etc., sendo que um é asoistente do seu s uperior immediado; graduação esta,que alem de se destinar para fins dis ciplinares, se suppoe de existir na graduaçâo e na hierarchia, tambem uma Gradual competencia technica;o que, a rigor, não se dá na Light and Power; I Imitando essa minha ponderâçâ, á Usina Thermica de Reserva;

Esga disparidade de tratamento, essa forma unilateral de ministrar a Justiça e majs outras coisas, muito lamentavels, provocou a gritaria e os protestos,por disso o Actual Chefe do Governo Provisorio quiz oppor um

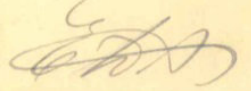




\section{- I6 -}

freio, aceito com evidente máo gosto pela Light and Power.

De forma que a GREVE; Os INQUERITO;as PUNIÇOES e as não reinte gra. cões ao serviço, representam tantas resistencias e obstrucionismo ás determinações legisletivas e dos Poderes Constituidos.

A diminuigea da importancia da Uaina Thermica de Reserva, có pode ver reconhecida ou não pelo Governo,e a propria Directoria da Ligint and Power gabedisso; sabe da sua utilidade,e por essa razão a mantem apparelhadá, cubstituindo apparelhos e instalações antiquadas; é devera extranhave - facto que agore se pretende fazer economia....extiguindo o lugar de/Asci stente do Chefe.

A Usina de Reserva é conolderada sempré de prontidão(material e funccionarios) exactamente como o material e funccionarios do Corpo dos Pombelros. Quando o material de um e de outra está em repouso,isto é quando não ha incendios e quando, respectivamente, não se verificam iñcidentes nas Inotalaçōes Hydro-Electricas; os funccionarios addictos, são empregados $\mathrm{n}$ a conservação do material, 1 sso é lo

Engraçado; quando na Usina de Reserva, muitas vezes mencionada, era preciso effectuar um exame nas machinas principaes, e mesmo nes auxiliares, - Chefe,J.D. Murray, tornavame meu ASSISTENTE, docil attencioso e prestadio, e nem elle, nem outros Chefes superiores, sentiram uma unica vez a necessidade de modificar a minha directriz, ou encontraram algo a dizer sobre o meu servi ço.

As vezes, esse Chefe, tentou ou entendeu meter as mañes em al gumas partes da Instalação, mas foi infeliz, visto desconlecer o proverbio genuinamente Erasilelro que diz,.. "Isso e por quem sabe e não para quem quer"; representando, esce pedacinho, uma prova poderosa, respeito a competencia. Quando a Usina Thermica de Reserva, ha suspeita ou posoibilidade - ser precisa, os Chefes Superiores, transmitem a ordem synthetica:

"A Usina Thermica se mantenha de prontidão simples".

"I. Ia.Bateria de Caldeiras com fogos accesos".

"A Ia.Bateria de Caldeiras com presgão reigulamentar".

"Vapor nas conductores no mais breve tempo posoivel". "Turbos-Geradores com rotaçõo, sem carğa".

"Iurbos-Geradores tal e tal, com toda carga". etc.

o Chefe ou o Assiotente do Chefe, dispoe os empregados disponiveis 
- I7 -

em duas ou tres guardas, conforme são as circumstancias, sendo quasi sempre divididos em duas GUARDAS.

Uma é Chefiada pela Chefe e outra pelo ASSISTENTE DO CHEFE; de forma que eu era Chefe da minha Guarda; dava ordens, determinava a substituição de caldeiras ou de machinas em serviço; fazia as manobras que o momento aconse 1 hava ser acertada;era o responsavel immediado da bóa marcha do servífo; de forma que a minha função não era decorativa. .

penso que ninguem juliga, que essa Usina possa funccionar sem os machindstas;sem um funccionario, pelo menos, treinado para substituir peças, examinar as machinas etcom cujo serviço, so triumpia, quem possue pratica, - com essas ponderações, tenho certeza que concordam,alem dos D. D. Niembros do C.N.T. mas todos os Machinistas e Chefes de Machinas da hosse Marinhe de Guerra.

D.D. Nembros do Conselho Nacional do Trabalho, prolixo fui na exposiร̧ão dos factos que cabalmente contestam a pretençâo da requerente Ii ght and Power, julguel assim proceder,afim de apresentar uma abundancis de decte1 hes, que Vos collocam em condição de julgar com acerto.

Fortanto, sobre esse caso, e sobre as allegações apresentadas,Os M.D. Membros do C.N.T., são chamados a pronunciar o "veredictum", esperando, JUSTIG - nada majo,alem do JUSTISA, determinando a minha immediada RIENTEGRA Ḉ̃O.

Rio de Jane1ro 3 =de Abril de 1934

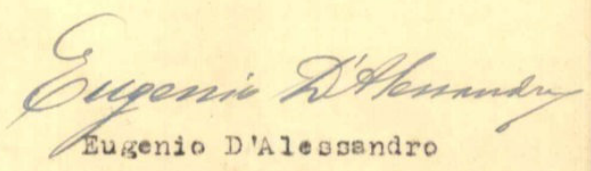


A.2 Acórdão da $2^{\mathrm{a}}$ Câmara do Conselho Nacional do Trabalho

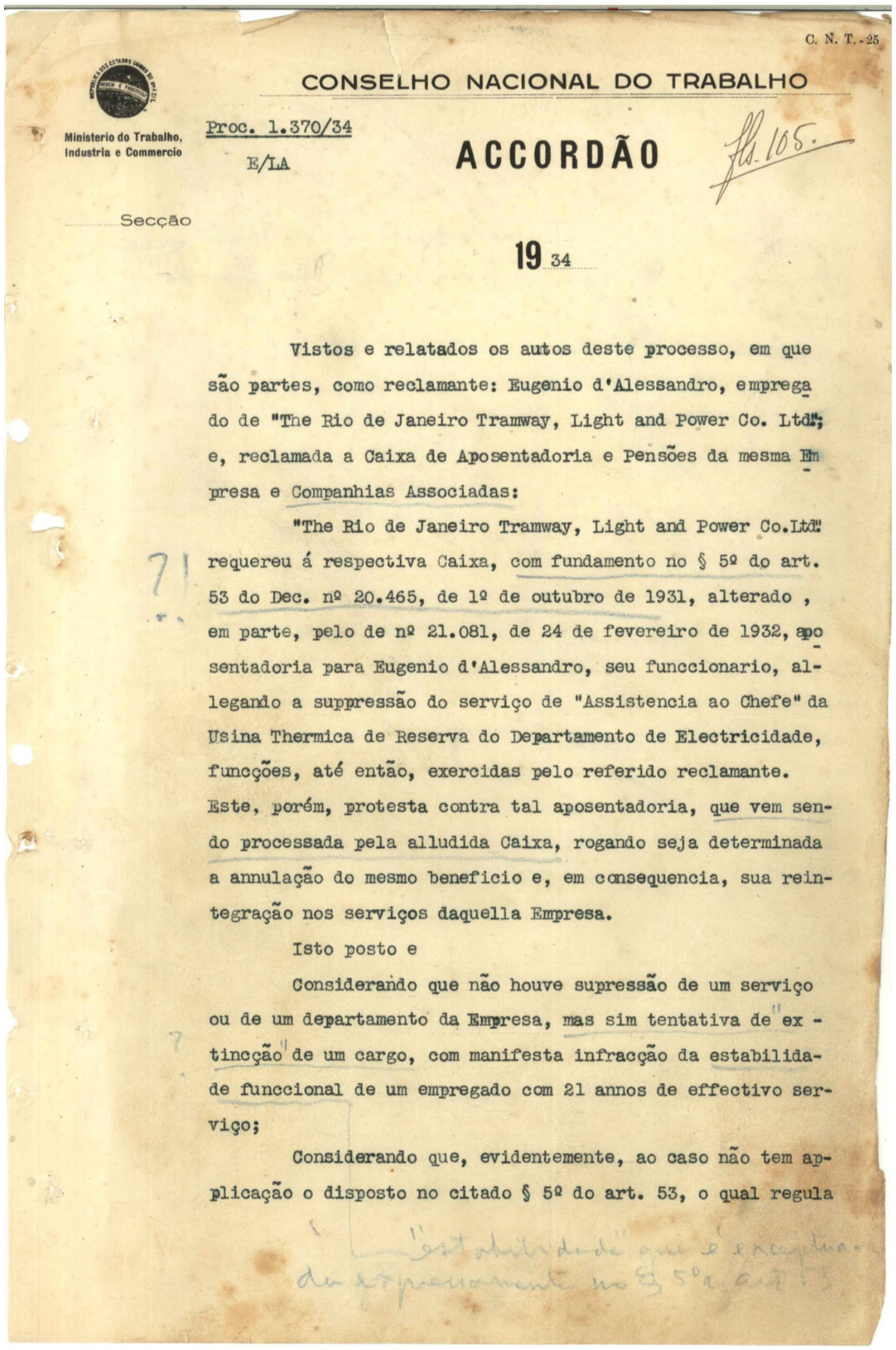




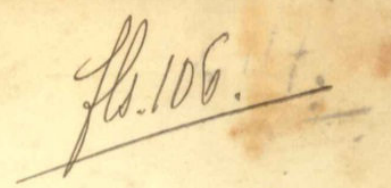

2.

uma aposentadoria toda excepcional, tanto assim que só póde ser applicado em se tratando de funccionarios já dispensados, em virtude de suppressão do serviço ou departamento onde trabalhavam, e nunca áquelles que ainda se encontram no exercieio do cargo;

Considerando que, aberto o precedente, teriam as Caixas de Aposentadoria e Pensões de assumir a responsabilidade das Empresas, quando estas não tivessem os meios legaes de dispensar os respectivos empregados can mais de 10 annos de serviço;

Resolvem os membros da 2a. Camara do Conselho Na cional do Trabalho julgar procedente a presente reclamação, afim de annulada a aposentadoria requerida ex-vi do citado art. $53, \S 59$, seja determinada a reintegração de Eugenio d.Alessandro nos serviços de "The Rio de Janeiro Tramway, Iight and Power Co. Ltd."

Rio de Janeiro, 19 de Outubro de 1934.

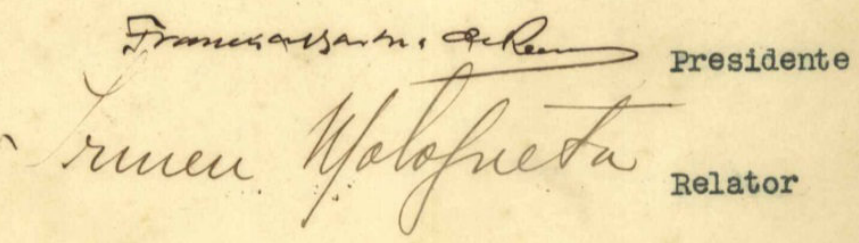

Fui presente - Gernediffinis Japtioln Procurador Geral, Publicado no "Diario official" de 3 de movem lero de 1934.

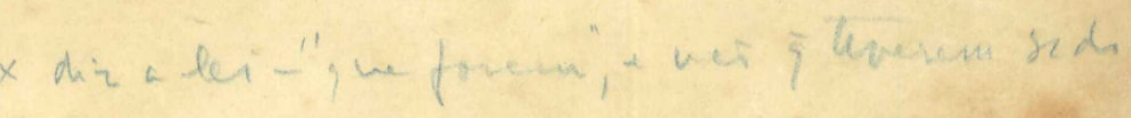




\section{A.3 Acórdão do Pleno do Conselho Nacional do Trabalho com voto vencido do Conselheiro Paranhos Fontenelle}

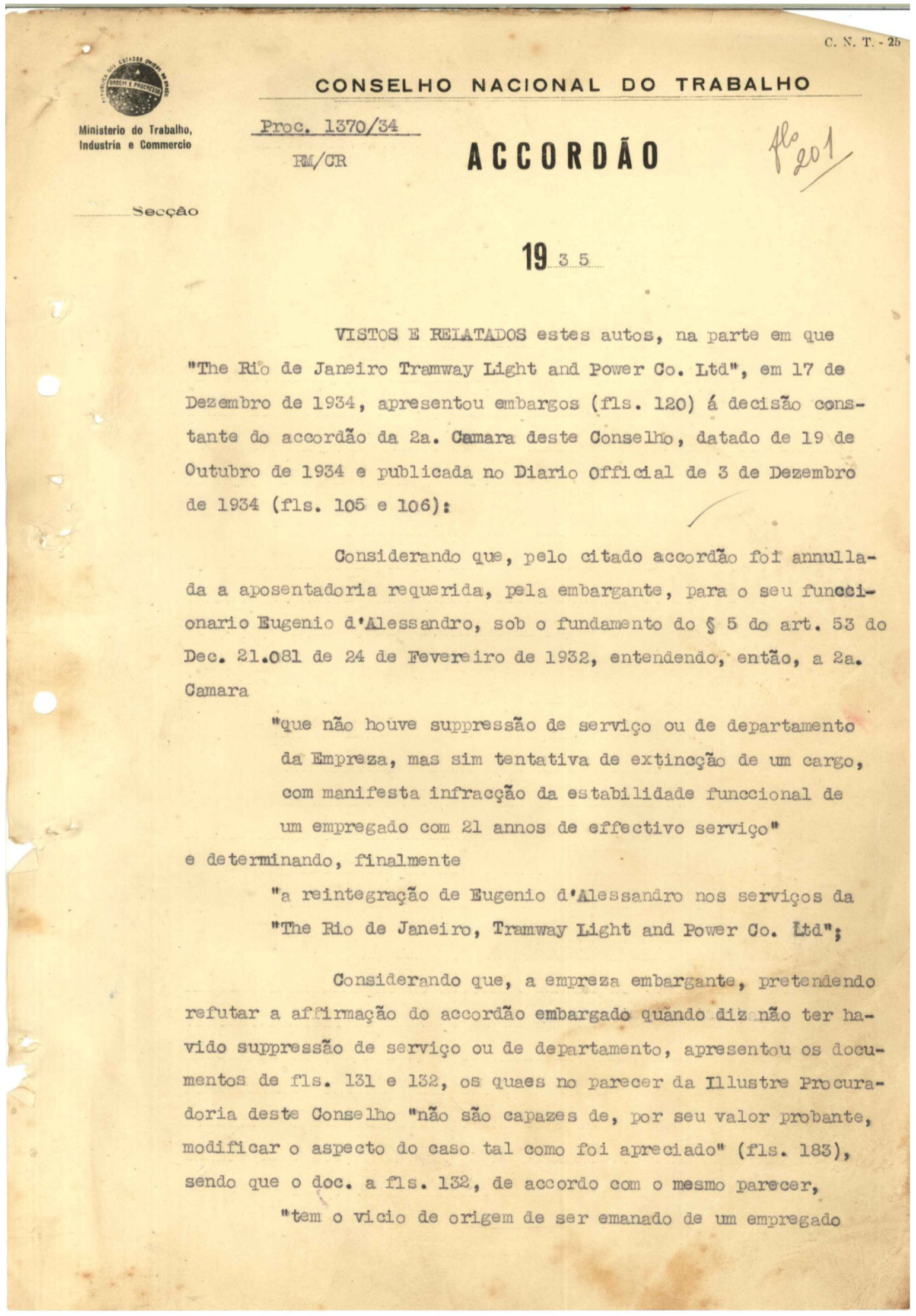


da empreza interessada e seu conteudo já foi, de certo modo, presente no primeiro julgamento, atravez da expo sição a fls. 7 e seguintes;

Considerando, que esses documentos não accrescentam nenhum elemento de convicção razoavel para refomar a decisão emhargada, antes concorrem ara a sua manutenção, porquanto comprovam que houve a suppressão de um cargo deteminado - "assistente de chefe" - na usina themica de Reserva e não de um "serviço" ou de "um departamento", sendo de notar que a justificaça de ser " "dispensavel a continua supervisão technica dạ Usina de Reserva" \& uma incoherencia no theor do mesmo documento, porque tal asserção implicaria na consequente sumpressão da pessoa que respondiapela chefia da mesma usina, chefia de que era eventual substituto o funccionario Engenio d'Alessandro;

Considerando, que não foi provada a data da remodelação da mencionada Usina e nem foi descripta a readaptação do pessoal á mesma incorjorado funccionalmente;

Considerando, que pela prova dos autos (docs. a fls. 7 e seguintes, e fls. 66 e fls. 132) o funccionario tugenio d•Alessandro, em 21 annos e pouco, de exercicio effectivo, trabalhou na referida Usina Thermica de Reserva, como mecanico, como engenheiro e finalmente como "assistente do chefe", cargo de que fol afastado;

Considerando, mais que o funccionario Bugenio d.Alessandro chegou a assumir, interinamente, a chefia do departamento da Usina de que era assistente (fls. 88);

Considerando, que por justa interpretação do $\$ 50$ do art. 53 do Dec. 21.081 de 24 de, Fevereiro de 1932, se deprehende tor sido estatuido pelo legislador um regimen excepcional, sendo que a aposentadoria nelle prevista so se coaduna com a suppressão de "serviço" ou de "departamento" pelo desapparecimento do seu objecto ou pella superveniencia de novas invenções, hypothese esta em que, de modo algum, fosse possivel o aprovei tamento dos empro. 


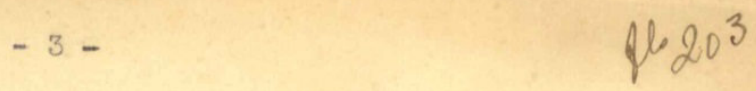

gados na mesma emproza, em funcções de remuneração e categoria equivalentes;

Considerando que as expresక̃oes "o serviço" e "o departamento" no $\$ 5 \Omega$ do citado art. 53, separadas pela disjunctiva "ou" são, logicamente, referidas a outro temo da oração - "das emprezas, e, por tal forma, ha de se entender, forgosamento, que é "o servico das emprezas" ou "o departamento das emrozas" de que se cosita no texto legal e não de uma funcção indivudual;

Considerando que de forma mais ampla "o serviço \& um complexo de operaços ou um systema de actividades adequadas a um objectivo e, no caso em exame, "o serviço" da empreza \& a producȩão e distribuição de energia electrica, continuando a ope. rar o respectivo departamento, ou secção de departamento - Usina Thermica de Reserva (fls. 132) por força, aliaz, do contracto de concessão;

Considerando, que acceita a doutrina proposta seria subverter, por completo, o espirito da lei, admittindo-se a aposentadoria por suppressão do cargo, ㅇ que implâtaria, definitivamente, a derrocada do re imen da estabilidade funccional;

Considerando, finalmente, que consentida a hypothese alvitrada pela embargante, fracassariam, fatalmente, as institui§ões de previdencia şocial, as quaes arcariam com os elementos que as emprezas pretendessem dispensar, concomendo, outrosim, innumeras possibilidades de fraudes contra as mesmas instituições, as quaes, de ordem e utilidade publica e de tão grande relevancia social, cumpre a este Conselho, como finalidade propria e precipua, defender (parte final do art. $53 \$ 50$ do dec. 21.081 de 24 de Fevereiro de 1932 e art. $12 \$ 2$, ne I, do Dec. 24.784 de 14 de JulTho de 1934).

Resolvem os membros do Conselho Nacional do TrabaTho, reunidos em Sessão Plena:

Preliminarmente, 
Interpretar o $\$ 52$ do art. 53 do Dec. 21.081 de 24 de Fevereiro de 1932, declarando não se conter, nesse preceito légal, a hypothese da suppressão de cargo.

\section{De Meritis}

Rejeitar os embargos e manter a decisão constante do accordão da 2a. Camara deste Conselho, datado de 19 de outubro de 1934 (fls. 105), annullando a aposentadoria concedida pela Caixa de Aposentadoria e Pensões das Companhias Light, Jardim Botanico e \$.A. du Gaz a Bugenio d.Alessandro e mandando reintegrar o mesmo Bugenio d.Mlessandro nos serviços da "The Rio de Janeiro Tramway Light and Power Co. Itä".

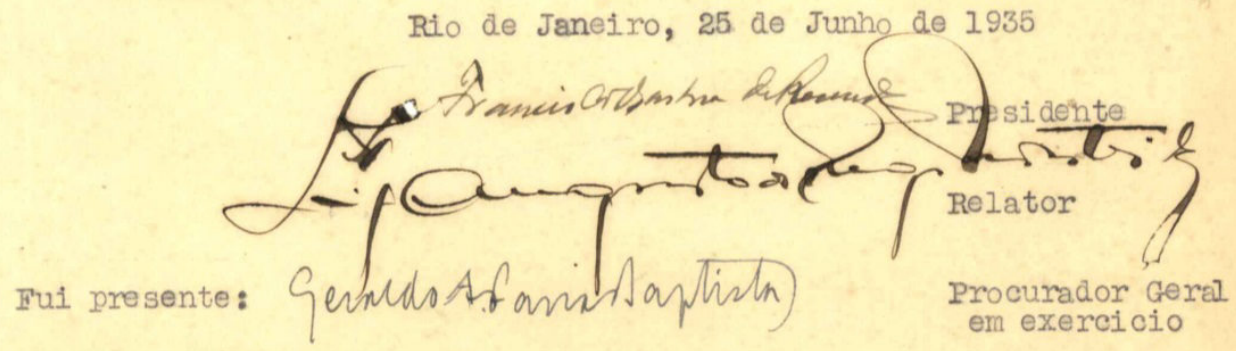

Publicado no "Diario official" de

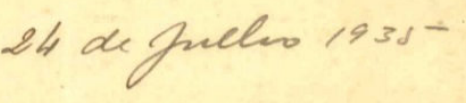

1. Parmus tomlendele vencido, com o seguinte voto:

Voto no sentido de se receberem os embargos de fls.

120 para que se modifique o Accordão de fls. 105 da 2a. Camara, e adopto, para recebel-os, as raz̃ões offerecidas pela embargante:

1. Com effeito, a primeira razão da embargante, que é o "Magrante conflicto" com outros julgados desse Conselho" e desrespeito á lei reguladora da especie, e terminante. Basta conhecer - fundamento do Accordão de 6 de Abril de 1933 (P.2-8912/32) em que se demonstra a incompetencia do Conselho, em face do Art. 10 do antigo regulamento (Dec. 18.074) e dos Arts. 51 e 64 do Dec. 20.465, para verificar-se que a 2 a. Camara não pođia intervir, como interveio, em favor de un denunciante, para quem a faculdade do $\S 10$ do ar. 5l, citado, ainda estava adormecida ou latente, de vez que não havia decisão da Junta toministrativa ou de vez que o empregado não poderia tomar-se recomente, contra acto cujos effeitos só teriam principiado (art. $51 \S \mathrm{Il}$ ) com a carta de notificação. 


\section{$-5-$}

A 2. Camara fez mais: traspof a lei. Tomando a iniciativa de exigir o processo, de $\mathbb{E}$. đ.Alessandro, da Caixa de Aposentadoria e Pensões da Comp. Light \& Power, como si já houvesse o objecto de reclamação ou a lesão de direito a reclamar, a 2a. Camara arrogou-se a falsa "competencia assessop/ia" que o Conselho the negou naquelle Accordão. A quem, depois, segue o processado, desde a inicial, subrepticiamente imposta á consideração da Pretidencia, surprehende a decisão ex-abrupto, contra o principio de escolastica - Natura non facet saltus - para intervir extra-officio. Na situação em que a Camara encontrou o processo, informado pela 2a. Secção em termos desfavoraveis á pretensão de Alessandro (fls. 35) e no estado em que o deparou, atravez do parecer techínico da Procuradoria (fls. 104) a resolução fi.ca desarticulada dos autos $\theta$ é, portanto, alem de aberrante, illogica.' '

2. A segunda razão da embargante que, essa sim, mostra o procedimento da Impreza, ante a realidade do facto e a existencia do complemento da lei, ou a razão de ter-se tornado o empregado dispensavel, por ter desapparecido o objecto do servico, 6 indiscutivel. Tão meridianamente clara ó essa disposição real da lei, - o $\$ 50$ do Art. 53 do Dec. 21.081 - que nem mesmo a attribuição que se faz erroneamente á Bmpreza, de fundar-se em terto supposto de un Decreto que não contem 0 \$ 5 daquelle artigo 53, poderia derogal-a. Mas a Cia. Light \& Power não requereu a aposentadoria de $\mathrm{F}$. deAlessandro, pois que este acto é deferido, por lei, ao empregado dispensado. Fez sim, e o fez, de accordo com a determinaৎ̧ão legal, valer um direito privativamente seu ou usar de uma faculdade sua, que o Conselho não the pode negar jamais, como of o direito expresso, nitido, insophismavel, que lhe outorga o preceito de que ella, como as suas congeneres companhias de concessão de serviço publico - autoras, aliás, da excepgão posterior - possue: - 0 poder de dispensar os empregados, embora validos, mas tomedos inuteis. Ora, essa excepgão é declarada pela negativa:

" \$5e (art 53 do Deov 21.081). Não se comprehendem igualmente neste artigo os empregados que se tenhhim tornado des- 


\section{$-6-$}

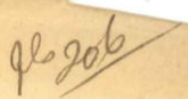

necessarios por ter sido supprimido o serviço ou o departamento das empresas em que trabalhavam, em virtude de ter

desapparecido 오 seu objecto ou pela superveniencia de novas invenções.

Si não se comprehendem neste artigo 53; si não se comprehendem na sanç̧ão de que "só poderão ser denittidos", é claro, clarissimo mesmo, grammatical e juridicamente, que "os "empregados que se tenham tornado desnecessarios por ter sido supprimido o serviço,"em virtude de ter desapparecido o seu objecto", podem ser demittidos pela Companhia, queira ou não queira a Gamara, porque não seria esta a tutora das empresasmpara admittir ou demittir os. seus empregados, nem o techinico que lhes fosse examinar a evolução ou retrocesso das normas industriaes, na exploração do serviço publico, de cuja exactidão, para com esse publico que paga, são flscaes competente"s outras repartiçoẽs。 $\forall$

Mas $\circ$ artigo de lei nãd se interpreta sinão á luz da razão e por hermeneatica segura, que tem de retroceder ate a origem da lei, declinada ad extremum e nunca ad initium, lei completa, sem a mutilação de seus complementos intelligiveis, para applical-a, integral, aos empregadas "dispensados em virtude de ter desapparecido o dbjecto do serviço, mas não differenciada, posta de abreviaçao manifesta sobre os funcionarios que se dizem ainda no exercicio de cargo supprimido.

Bastava ver que a estabilidade funccional, de que vieram a cogitar as Camaras, depois de 14 de Agosto de 1934 (Art. 13 do Dec. 24.784) \& bem differente da garantia que, vencdda aquella, assegura a lei, então, aos empregados demittidos, por falta grave $e$ aos dispensados, por desnecessarios, e que esse garantia se acha definida pela faculdade de continuarem como associados da cadxa, no primeiro caso, e o direito de se aposentarem, na segunda hypothese.

Depapparecido o objecto do servico - como desappareceu, pois que a assistencia de B. d.Alessandro a seu chefe foi nenhuma (fls. 127), sem que dessa nullidade decorresse prejuizo ao serviço, ou melhor, sem que a fiscalização, regulada pela lei federal, por essa falta de auxilio, tivesse negado á empreza o procedimento legal de 


\section{$-7-$}

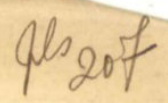

"quem attendendo normalmente ás necessidades publicas de expansão e melhoramento" desses serviços (Art. 137 da Constituição) teria desapparecido, ipso facto, o empregado. Impugnar á empreza a prova de que a desnecessidade do serviço deve ser offerecida pelos seus techimicos e responsaveis, é impugnar a opinião do ajudado quando declara que o seu ajudante não the presta auxilio. Si amanhã este Conselho desejasse saber si o Adjunto de procurador \& necessario \& Procuradoria, não iria indagar do Consultor da Republica, porque sua autoridade não Ihe daria a observação funccional que tem o procurador locale para responder em causa propria.

Duvida houvesse ainda e perguntariamós nós:

Qual 8 o objecto de assistencia a uma chefia de serviço? B a resposta seria: - ajudar essa chefia. De sorte que, como $\theta$ a chefia do serviço da Istação da Reserva que declara - nota beñe -, justamente no documento de que mais se valle o denunciante, para impor a sua capacidade imprescindivel (fls. 70 verso) -" que as seus , engenheiros dovem permanecer nos seus postos, mas como se trata de um velho empregado, que se pode dispensar os servicos do $\underline{\mathrm{Snr}}$. di.Alessandro" (sic), nenhuma jrova é maior attestado da nullidade do auxilio do assistente, do que a relegação de suas funcções para uma epocha de alem-ferias ou de passividade, fora de seu posto.

3. Mas, forcemos a contra-prova e acceitemos que d.Allesandro/ não seja daquelles engenhelros reclamados, nem assistente do chefe da Usina Thermica da Reserva, não porque o tenham atemorizado as comminalónes sonantes do Dec. ne 23.569 (Regulamentação da profissão, de engenheiro) mas por quanto de palmar existe no erro do seu calculo de correspondencia entre as capacidades electrica e thermica da Usina. Essa contra-prova, de uma solicitude de juiz de paz, teria entretanto esbarrado nos documentos de fls. 163 e 164, para permittir reconhecer, como nem o proprio embargado consegue impedirk na sua enrodilhada contradicta ( 1 ls. 173 a 181), que o titulo mesmo abreviado de "Assistente Engenheiro Chefia Reserva", que lhe enfeita o nome, de Abril de 1932 ( 1 s. 163) a Setembro de 1933 (fls. 164) se encontra em folha de pagamento sob a consignação de, chefes e Sub-chefes 


\section{$-8-$}

$9 \log 208$

Seria esse o argumento para desencantar a ingenuidade daquelles que começavam a acreditar no espirito de renuncia do denunciante - que não quer ser assistente, com 1;200\$000 mensaes, mas sim um simples machinista ( 1 s. 180) com ordenado especial, maior, em todo o caso que o do chefe actual da Uzina, se superior hierarchico.

2. Chegamos, por fim, ás razões finaes da embargante e que justificam a regularidade da aposentadoria, processada para definir a situação confusa que a presença passiva de um empregado, ha cerca de dois annos dispensado do exercicio activo da empreza, viera crear na sua disciplina e na sua economia de servidora publica. ora, não sర a jurisprudencia deste Conselho (Áccordão de 6 de Abril e de 11 de Agosto de 1933), mas a propria doutrina (estabilidade ou garantia) teriam soffrido grave ameaça, se admittiramos, como admittiu o Accoraão embarga/ao, a pratica de se considerar ainda em serviço ủm empregado, cuja estabilidade de funcção cessou, nas condições derininidas pela excepcão do $\$ 52$ do Art. 53 do Dec. 21.081. Nas considerar aindá, como o fez a 2a. Camara, em sua resolução de fls. 105, que

"ao caso não tem applicação o disposto no citado $§ 50$ do

Art. 53, o qual regula uma aposentadoria toda excepcional", já não é mais ameaçar a jurisprudencịa do Conselho, á doutrina e á. tradição de justiça da Casa. 'A enverter, por tal modo, os termos da lei que - força é confessar - nesse fundamento de decisão, So se reconhece a existencia do caso, para favorecer o empregado, não $c$ com a garantia dada palo paragrapho 5\%, mas para lhe conferir a estabilidade, que a lei declara expressamente não se comprehender no artigo 53.

I no final de tudo, reconhecer que a aposentadoria desapparece, contra o espirito da excepção, diante da dispensa do emprogado; que o direito do funccionario, na justiça neo-social da Capu, sobrevive á função extincta; e que a faculdade legitima ainda ha bem pouco tempo declarada pela Iei $n e 62$ de 5 de Junho do corrente anno (Diario official de 11 de Junho de 1935) que tem os empregadores de despedir os empregados, por causa justa e forca maior, em que se inclue a suppressão do emprego ou cargo, aconselhađa pelas condições 


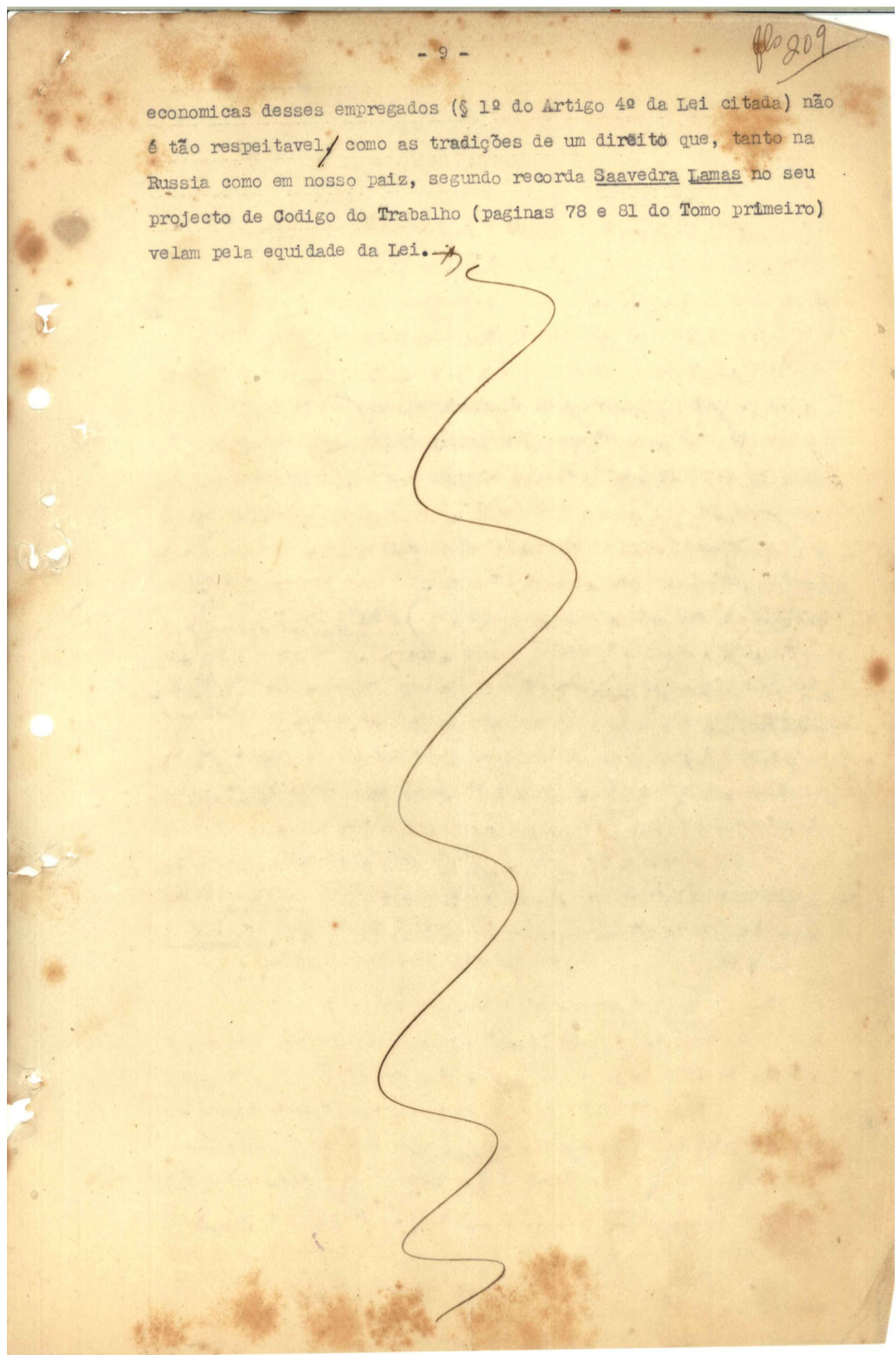


A.4 Acórdão do Pleno do Conselho Nacional do Trabalho que impõe multa à Light pelo descumprimento da ordem de reintegração de Eugenio D'Alessandro

C. N. T. -25

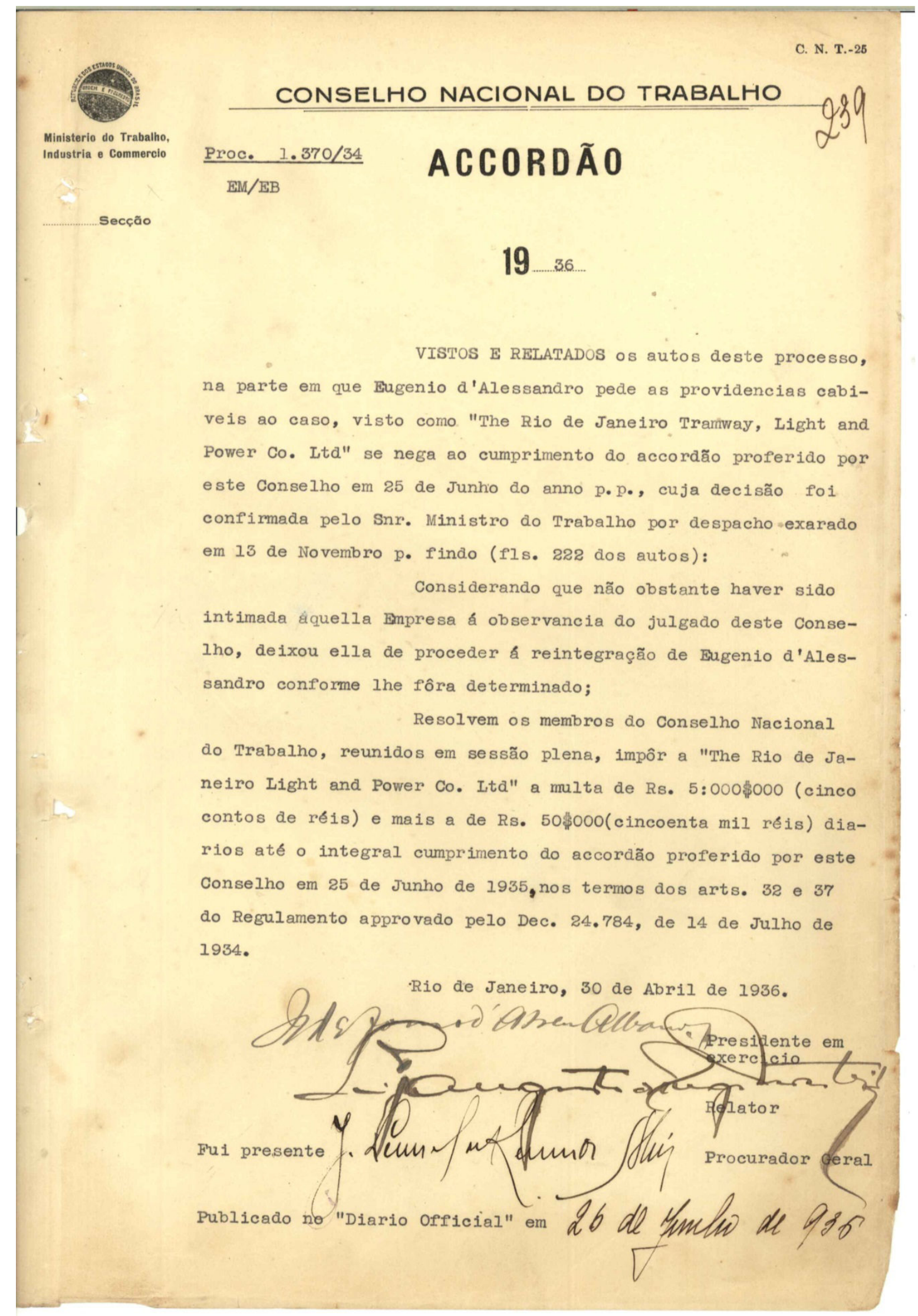

